Prepared in cooperation with the

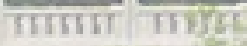
Federal Emergency Management Agency

\title{
Flood of June 26-29, 2006, Mohawk, Delaware and Susquehanna River Basins, New York
}

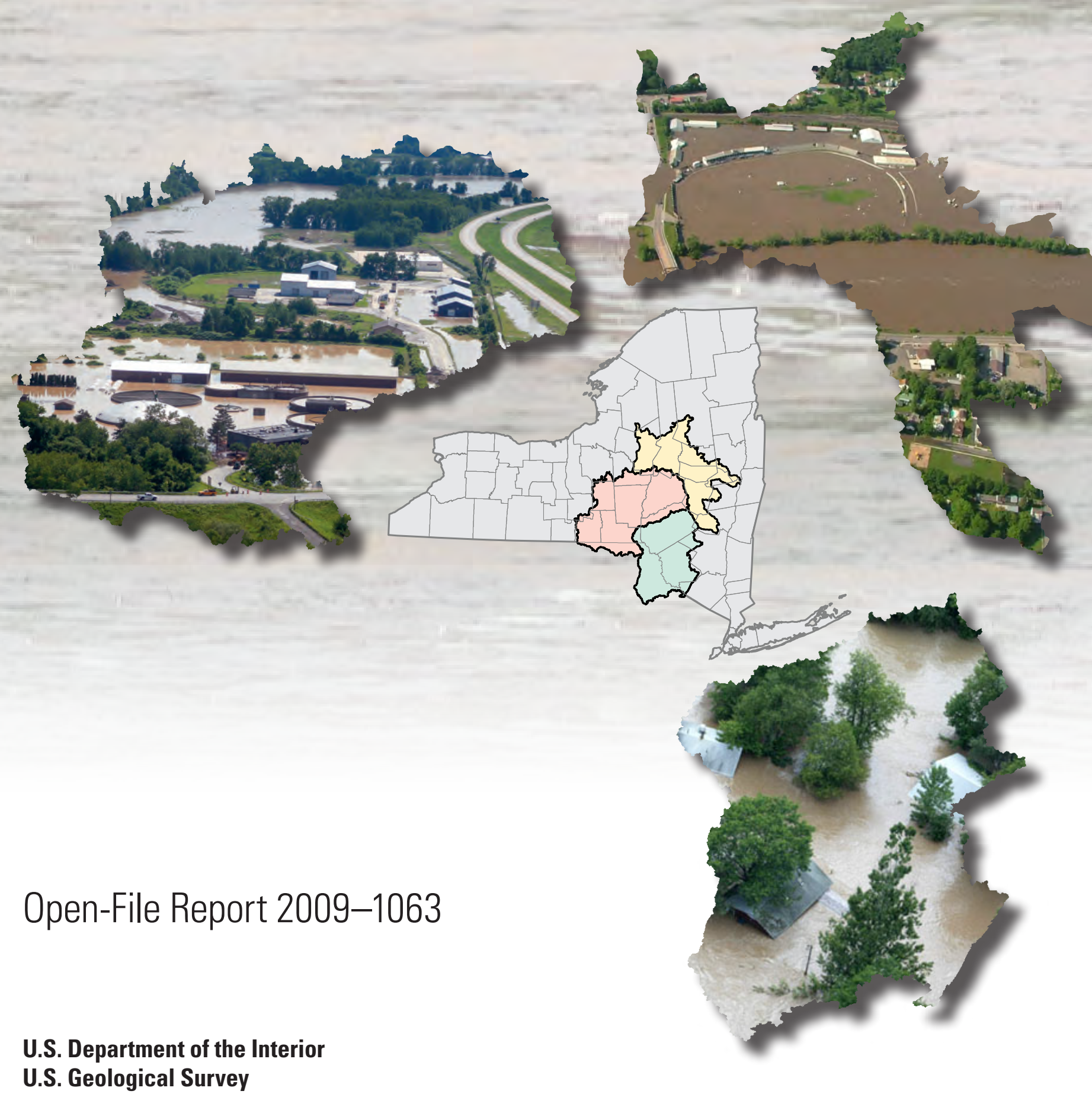


Cover. Bridge (background image): Riverside Drive bridge, Binghamton, NY, on June 28, 2006. Photo courtesy of Jim DeVona.

Mohawk River basin: Fonda Speedway near Fonda, NY, on June 28, 2006. Photo courtesy of Ryan Peterson and Valley View Aviation

Delaware River basin: Narrowsburg, NY, inundated by the floodwaters of the Delaware River on June 28, 2006. Photo courtesy of the Times Herald-Record, taken by staff photographer Jeff Goulding.

Susquehanna River basin: Oneonta, NY, municipal complex and wastewater treatment plant taken from Army National Guard helicopter on June 29, 2006. Photo courtesy of The Daily Star, taken by photographer Anita Briggs. 


\section{Flood of June 26-29, 2006, Mohawk, Delaware, and Susquehanna River Basins, New York}

By Thomas P. Suro, Gary D. Firda, and Carolyn 0. Szabo

Prepared in cooperation with the Federal Emergency Management Agency

Open-File Report 2009-1063 


\title{
U.S. Department of the Interior \\ KEN SALAZAR, Secretary \\ U.S. Geological Survey \\ Marcia K. McNutt, Director
}

\section{U.S. Geological Survey, Reston, Virginia: 2009}

\author{
For more information on the USGS — the Federal source for science about the Earth, its natural and living resources, \\ natural hazards, and the environment, visit http://www.usgs.gov or call 1-888-ASK-USGS \\ For an overview of USGS information products, including maps, imagery, and publications, \\ visit http://www.usgs.gov/pubprod \\ To order this and other USGS information products, visit http://store.usgs.gov
}

\begin{abstract}
Any use of trade, product, or firm names is for descriptive purposes only and does not imply endorsement by the U.S. Government.

Although this report is in the public domain, permission must be secured from the individual copyright owners to reproduce any copyrighted materials contained within this report.
\end{abstract}

Suggested citation:

Suro, T.P., Firda, G.D. and Szabo, C.0. 2009, Flood of June 26-29, 2006, Mohawk, Delaware, and Susquehanna River Basins, New York: U.S. Geological Survey Open-File Report 2009-1063, 354p. Available online at http://pubs.usgs. gov/ofr/2009/1063 


\section{Contents}

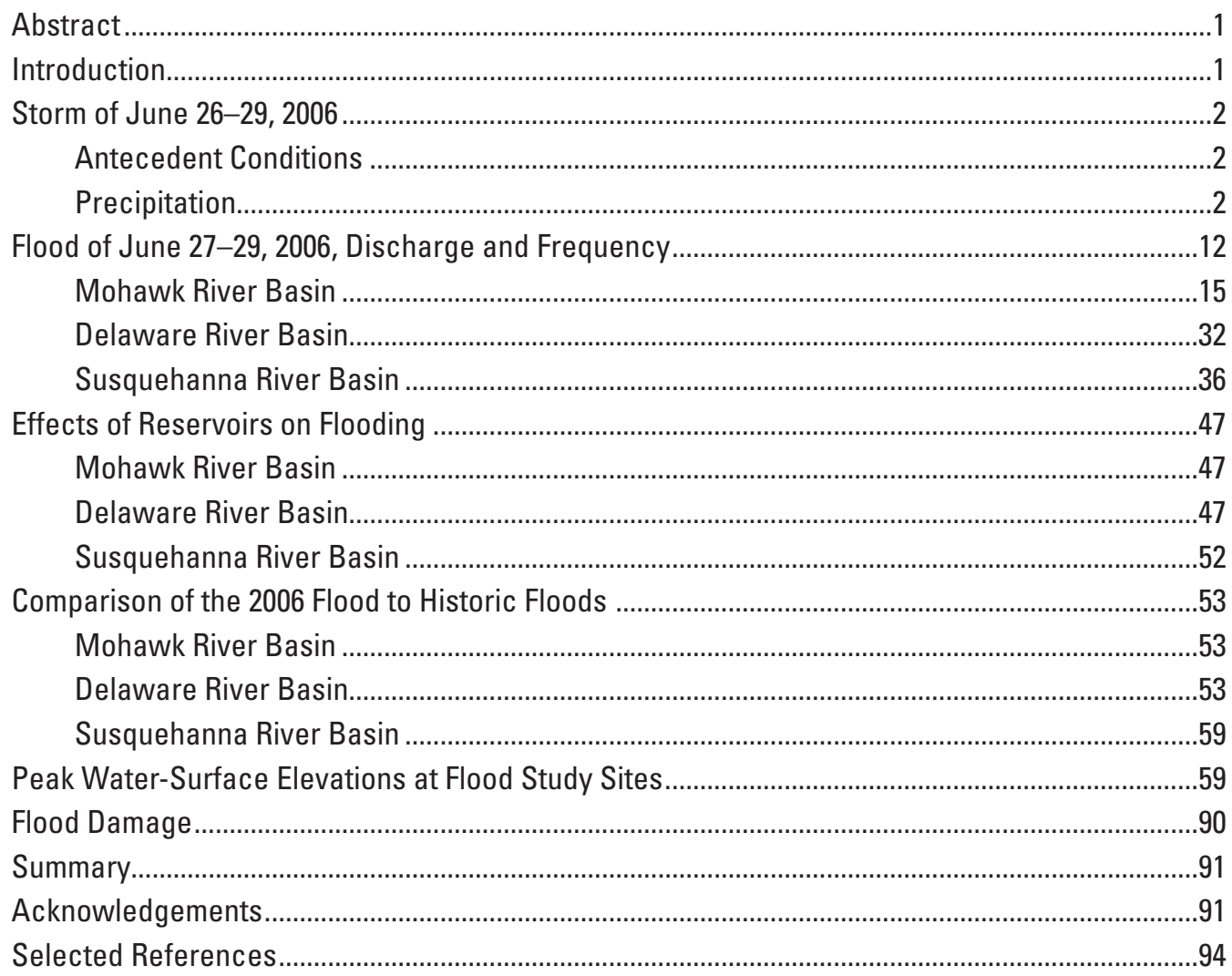

Appendix 1. Site Descriptions and High-Water Marks at Study Sites, Flood of June 26-29, 2006, in the Mohawk, Delaware, and Susquehanna River Basins, New York.

Appendix 2. Comparison of High-Water Marks and Photographs at Selected Study Sites, Floods of September 18-19, 2004, and June 26-29, 2006, Delaware River Basin, New York.

Appendix 3. Selected Photographs of Flood Damage During the Flood of June

26-29, 2006, Mohawk, Delaware, and Susquehanna River Basins, New York.

\section{Figures}

1A. Map showing cumulative 4-day rainfall for the storm of June 26-29, 2006, and pertinent geographic features of New York

1B. Map showing daily rainfall totals for the storm of June 26-29, 2006, and pertinent geographic features of New York.

1C. Map showing total rainfall in the Mohawk River basin, NY, and surrounding area for the storm of June 26-29, 2006.

1D. Map showing total rainfall in the Delaware River basin, NY, and surrounding area for the storm of June 26-29, 2006.

1E. Map showing total rainfall in the Susquehanna River basin, NY, and surrounding area for the storm of June 26-29, 2006 
2A. Graph showing cumulative hourly rainfall during June $25-28,2006$, recorded at the National Weather Service hourly recording station at Claryville, NY.

2B. Map showing cumulative hourly rainfall during June 25-28, 2006, recorded at the National Weather Service office at Binghamton, NY.

2C. Map showing cumulative hourly rainfall during June 23-28, 2006, recorded at the New York City Department of Environmental Protection station at Cannonsville Reservoir, NY.

2D. Map showing cumulative hourly rainfall during June $25-28,2006$, recorded at Albany International Airport, NY..

3A. Map showing total precipitation in the Susquehanna River basin and surrounding area for the storms of March 9-22, 1936.

3B. Map showing total rainfall in New York and surrounding area for the storm of June 19-23, 1972.

4A. Map showing locations of selected U.S. Geological Survey stream-gaging stations in the Mohawk River basin, NY, and surrounding area.

4B. Map showing locations of selected U.S. Geological Survey stream-gaging stations in the Delaware River basin, NY, and surrounding area

4C. Map showing locations of selected U.S. Geological Survey stream-gaging stations in the Susquehanna River basin, NY, and surrounding area..

5A. Graph showing peak discharges for the flood of June 26-29, 2006, and previous maximum known discharge at selected stream-gaging stations in the Hudson River basin, NY, as a function of drainage area.

5B. Graph showing peak discharges for the flood of June 26-29, 2006, and previous maximum known discharge at selected stream-gaging stations in the Delaware River basin, NY, as a function of drainage area.

5C. Graph showing peak discharges for the flood of June 26-29, 2006, and previous maximum known discharge at selected stream-gaging stations in the Susquehanna River basin, NY, as a function of drainage area.

6A. Map showing peak discharge recurrence intervals at selected U.S. Geological Survey stream-gaging stations in the Mohawk River basin, NY, for the flood of June 26-29, 2006.

6B. Map showing peak discharge recurrence intervals at selected U.S. Geological Survey stream-gaging stations in the Delaware River basin, NY, for the flood of June26-29, 2006.

6C. Map showing peak discharge recurrence intervals at selected U.S. Geological Surveystream-gaging stations in the Susquehanna River basin, NY, for the flood of June 26-29, 2006.

7A. Graph showing annual peak discharges through 2006, and discharges of the 10-, 50-, and 100-year recurrence intervals for selected stations in the Mohawk River basin, NY

7B. Graph showing annual peak discharges through 2006, and discharges of the 10-, 50-, and 100-year recurrence intervals for selected stations in the Delaware River basin, NY

7C. Graph showing annual peak discharges through 2006, and discharges of the $10-, 50-$, and 100-year recurrence intervals for selected stations in the Susquehanna River basin, NY

8. Graph showing discharge hydrographs for selected stream-gaging stations in the (A-1) Mohawk River basin, NY, June 25-30, 2006, (B-1 to B-5) Delaware River basin, NY, June 25-30, 2006, and (C-1 to C-2) Susquehanna River basin, NY, June 25-30, 2006. 
9A-1. Graph showing fifteen minute inflow, and water-surface elevation at the Hinkley Reservoir, NY, June 26-30, 2006.

9A-2. Graph showing fifteen minute inflow, outflow, diversions and water-surface elevation at the Schoharie Reservoir, NY, June 26-30, 2006

9B-1. Graph showing fifteen minute inflow, outflow, diversions and water-surface elevation at the Pepacton Reservoir, NY, June 26-30, 2006.

9B-2. Graph showing fifteen minute inflow, outflow, diversions and water-surface elevation at the Cannonsville Reservoir, NY, June 26-30, 2006.

9B-3. Graph showing fifteen minute inflow, outflow, diversions and water-surface elevation at the Neversink Reservoir, NY, June 26-30, 2006

9C-1. Graph showing fifteen minute outflow and water-surface elevation at the East Sidney Lake, NY, June 26-July 1, 2006

9C-2. Graph showing fifteen minute discharges at selected stream-gaging stations upstream and downstream of Whitney Point Lake and water-surface elevation at Whitney Point Lake, NY, June 26-30, 2006.

10A. Graph showing discharge hydrographs for selected historic floods at (1) the Mohawk River nearLittle Falls, NY, and (2) the Mohawk River at Cohoes, NY, stream-gaging stations.

10B. Graph showing discharge hydrographs for selected stream-gaging stations in the Delaware River basin, NY, for the June 2006 and August 1955 floods.

10C. Graph showing discharge hydrographs for selected historic floods at (1) the Susquehanna River near Waverly, NY, and (2) the Susquehanna River at Conklin, NY, stream-gaging stations

11. Graph showing water-surface elevation in the Pepacton Reservoir, NY, during August-October 1955, January 1996, and June 2006

12A. Map showing locations of 22 high-water-mark sites chosen for study in the Mohawk River basin, NY, for the flood of June 26-29, 2006

12B. Map showing locations of 44 high-water-mark sites chosen for study in the Delaware River basin, NY, for the flood of June 26-29, 2006

12C. Map showing locations of 38 high-water-mark sites chosen for study in the Susquehanna River basin, NY, for the flood of June 26-29, 2006

13A. Graph showing peak water-surface elevations at selected sites in the Mohawk River basin, NY, during flood of June 26-29, 2006, and floodrecurrence-interval elevations from Federal Emergency Management Agency flood-insurance studies

13B. Graph showing peak water-surface elevations at selected sites in the Delaware River basin, NY, during flood of June 26-29, 2006, and floodrecurrence-interval elevations from Federal Emergency Management Agency flood-insurance studies

13C. Graph showing peak water-surface elevations at selected sites in the Susquehanna River basin, NY, during flood of June 26-29, 2006, and floodrecurrence-interval elevations from Federal Emergency Management Agency flood-insurance studies

14A. Photographs of Collapse of Interstate Route 88 over Carrs Creek near Unadilla (Exit 10), NY, on June 28, 2006. Bottom-Carrs Creek and washed-out culvert at Interstate Route 88 near Unadilla (exit 10), NY, on June 28, 2006

14B. Photographs of Susquehanna River floodwaters overtop floodwall along North Shore Drive, Binghamton, NY, on June 28, 2006, and Susquehanna River floodwaters overflow Washington Street pedestrian bridge, Binghamton, NY, on June 28,2006 


\section{Tables}

1. Total rainfall for the storm of June 26-29, 2006, at selected locations in New York and surrounding areas.

2A. Rainfall-frequency relations for storms of 3-, 6-, 12-, and 24-hour duration at selected locations in New York

2B. Rainfall-frequency relations for storms of 4-day duration at selected locations in New York

3. Period-of-record peak discharges and peak discharges during the flood of June $26-29,2006$, at selected U.S. Geological Survey stream-gaging stations in New York and surrounding areas.

4A. Peak elevations and peak discharges for selected historical floods and the June 26-29, 2006, flood at selected U.S. Geological Survey stream-gaging stations in the Mohawk River basin, NY

4B. Peak elevations and peak discharges for selected historical floods and the June 26-29, 2006, flood at selected U.S. Geological Survey stream-gaging stations in the Delaware River basin, NY.

4C. Peak elevations and peak discharges for selected historical floods and the June 26-29, 2006, flood at selected U.S. Geological Survey stream-gaging stations in the Susquehanna River basin, NY.

5A. Peak water-surface elevations at 22 high-water-mark sites and 5 U.S. Geological Survey stream-gaging stations in the Mohawk River basin, NY, during the flood of June 26-29, 2006, and corresponding flood elevations for 10-, 50-, 100-, and 500 -year flood-recurrence intervals.

5B. Peak water-surface elevations at 44 high-water-mark sites and 10 U.S. Geological Survey stream-gaging stations in the Delaware River basin, NY, during the flood of June 26-29, 2006, and corresponding flood elevations for 10-, 50-, 100-, and 500 -year flood-recurrence intervals.

5C. Peak water-surface elevations at 38 high-water-mark sites and 14 U.S. Geological Survey stream-gaging stations in the Susquehanna River basin, NY, during the flood of June 26-29, 2006, and corresponding flood elevations for 10-, 50-, 100-, and 500 -year flood-recurrence intervals. 


\section{Conversion Factors, Datum, and Acronyms}

\begin{tabular}{|c|c|c|}
\hline Multiply & By & To obtain \\
\hline \multicolumn{3}{|c|}{ Length } \\
\hline inch (in.) & 2.54 & centimeter $(\mathrm{cm})$ \\
\hline foot $(\mathrm{ft})$ & 0.3048 & meter $(\mathrm{m})$ \\
\hline mile (mi) & 1.609 & kilometer $(\mathrm{km})$ \\
\hline \multicolumn{3}{|c|}{ Area } \\
\hline acre & 4,047 & square meter $\left(\mathrm{m}^{2}\right)$ \\
\hline acre & 0.4047 & hectare (ha) \\
\hline acre & 0.4047 & square hectometer $\left(\mathrm{hm}^{2}\right)$ \\
\hline acre & 0.004047 & square kilometer $\left(\mathrm{km}^{2}\right)$ \\
\hline square foot $\left(\mathrm{ft}^{2}\right)$ & 929.0 & square centimeter $\left(\mathrm{cm}^{2}\right)$ \\
\hline square foot $\left(\mathrm{ft}^{2}\right)$ & 0.09290 & square meter $\left(\mathrm{m}^{2}\right)$ \\
\hline square mile $\left(\mathrm{mi}^{2}\right)$ & 259.0 & hectare (ha) \\
\hline square mile $\left(\mathrm{mi}^{2}\right)$ & 2.590 & square kilometer $\left(\mathrm{km}^{2}\right)$ \\
\hline \multicolumn{3}{|c|}{ Volume } \\
\hline million gallons (Mgal) & 3,785 & cubic meter $\left(\mathrm{m}^{3}\right)$ \\
\hline cubic foot $\left(\mathrm{ft}^{3}\right)$ & 28.32 & cubic decimeter $\left(\mathrm{dm}^{3}\right)$ \\
\hline cubic foot $\left(\mathrm{ft}^{3}\right)$ & 0.02832 & cubic meter $\left(\mathrm{m}^{3}\right)$ \\
\hline acre-foot (acre-ft) & 1,233 & cubic meter $\left(\mathrm{m}^{3}\right)$ \\
\hline acre-foot (acre-ft) & 0.001233 & cubic hectometer $\left(\mathrm{hm}^{3}\right)$ \\
\hline \multicolumn{3}{|c|}{ Flow rate } \\
\hline acre-foot per day (acre-ft/d) & 0.01427 & cubic meter per second $\left(\mathrm{m}^{3} / \mathrm{s}\right)$ \\
\hline cubic foot per second $\left(\mathrm{ft}^{3} / \mathrm{s}\right)$ & 0.02832 & cubic meter per second $\left(\mathrm{m}^{3} / \mathrm{s}\right)$ \\
\hline $\begin{array}{l}\text { cubic foot per second per square mile } \\
{\left[\left(\mathrm{ft}^{3} / \mathrm{s}\right) / \mathrm{mi}^{2}\right]}\end{array}$ & 0.01093 & $\begin{array}{l}\text { cubic meter per second per square } \\
\text { kilometer }\left[\left(\mathrm{m}^{3} / \mathrm{s}\right) / \mathrm{km}^{2}\right]\end{array}$ \\
\hline million gallons per day (Mgal/d) & 0.04381 & cubic meter per second $\left(\mathrm{m}^{3} / \mathrm{s}\right)$ \\
\hline
\end{tabular}

Temperature in degrees Celsius $\left({ }^{\circ} \mathrm{C}\right)$ may be converted to degrees Fahrenheit $\left({ }^{\circ} \mathrm{F}\right)$ as follows:

$$
{ }^{\circ} \mathrm{F}=\left(1.8 \times{ }^{\circ} \mathrm{C}\right)+32
$$

Temperature in degrees Fahrenheit $\left({ }^{\circ} \mathrm{F}\right)$ may be converted to degrees Celsius $\left({ }^{\circ} \mathrm{C}\right)$ as follows:

$$
{ }^{\circ} \mathrm{C}=\left({ }^{\circ} \mathrm{F}-32\right) / 1.8
$$

Vertical coordinate information is referenced to National Geodetic Vertical Datum of 1929 (NGVD 29).

Horizontal coordinate information is referenced to North American Datum of 1983 (NAD 83).

Barge Canal Datum (BCD) is site specific and there are local conversion factors, in feet, to National Geodetic Vertical Datum of 1929. 
Acronyms Used in This Report

FEMA Federal Emergancy Management Agency

NGS National Geodetic Survey

NWS National Weather Service

NYCDEP New York City Department of Environmental Protection

NYSDOT New York State Department of Transportation

PPL Pennsylvania Power and Light Corporation

USGS U.S. Geological Survey 


\title{
Flood of June 26-29, 2006, Mohawk, Delaware, and Susquehanna River Basins, New York
}

\author{
By Thomas P. Suro, Gary D. Firda, and Carolyn O. Szabo
}

Abstract

A stalled frontal system caused tropical moisture to be funneled northward into New York, causing severe flooding in the Mohawk, Delaware, and Susquehanna River basins during June 26-29, 2006. Rainfall totals for this multi-day event ranged from 2 to 3 inches to greater than 13 inches in southern New York. The storm and flooding claimed four lives in New York, destroyed or damaged thousands of homes and businesses, and closed hundreds of roads and highways. Thousands of people evacuated their homes as floodwaters reached new record elevations at many locations within the three basins. Twelve New York counties were declared Federal disaster areas, more than 15,500 residents applied for disaster assistance, and millions of dollars in damages resulted from the flooding. Disaster-recovery assistance for individuals and businesses adversely affected by the floods of June 2006 reached more than \$227 million.

The National Weather Service rainfall station at Slide Mountain recorded storm totals of more than 8 inches of rainfall, and the stations at Walton and Fishs Eddy, NY, recorded storm totals of greater than 13 inches of rainfall. The U.S. Geological Survey (USGS) stream-gaging stations at Mohawk River at Little Falls, West Branch Delaware River at Hale Eddy, and Susquehanna River at Vestal, NY, among others, recorded peak discharges of 35,000 ft $3 / \mathrm{s}, 43,400 \mathrm{ft}^{3} / \mathrm{s}$, and $119,000 \mathrm{ft}^{3} / \mathrm{s}$ respectively, with greater than 100 -year recurrence intervals. The peak water-surface elevation $21.47 \mathrm{ft}$ and the peak discharge $189,000 \mathrm{ft}^{3} / \mathrm{s}$ recorded on June 28, 2006, at the Delaware River at Port Jervis streamgaging station were the highest recorded since the flood of August 1955. At the Susquehanna River at Conklin, NY, stream-gaging station, which has been in operation since 1912, the peak water-surface elevation $25.02 \mathrm{ft}$ and peak discharge $76,800 \mathrm{ft}^{3} / \mathrm{s}$ recorded on June 28,2006 , exceeded the previous period-of-record maximums that were set during the flood of March 1936. Documented peak water-surface elevations during the June 2006 flood at many study sites in the Mohawk, Delaware, and Susquehanna River basins exceeded the 100-year flood-profile elevations determined in the flood-insurance studies prepared by the Federal Emergency Management Agency.

\section{Introduction}

Major flooding occurred during June 26-29, 2006, across New York State and adjacent states resulting from a stalled frontal boundary that funneled tropical moisture over New York, New Jersey, and Pennsylvania. Prior to June 2006, streamflow conditions in the Mohawk and Delaware River basins generally were within the normal range, and conditions in the Susquehanna River basin were in the dry range. Heavy rains spread from south to north across central New York from June 26 through June 29, 2006, producing rainfall totals that generally ranged from 2 to greater than $7 \mathrm{in}$. in many areas with localized rainfall totals of greater than 10 to $13 \mathrm{in}$. in several parts of southern New York. The National Weather Service (NWS) recorded rainfall amounts of 3.62 in. at Albany, 7.13 in. at Binghamton, and 13.36 in. at Walton, NY (National Oceanic and Atmospheric Administration, 2006a). The storm and flooding claimed four lives in New York, destroyed or damaged thousands of homes and businesses, and closed hundreds of roads and highways.

Several USGS stream-gaging stations along the Mohawk, Delaware, and Susquehanna River basins recorded peak discharges with a recurrence interval of greater than 100-years during the June 2006 flood. A state of emergency was declared in many counties in southern New York including Broome, Chenango, Delaware, Montgomery, Sullivan, and Ulster. According to the New York State Department of Transportation (New York State Department of Transportation, 2006), on Wednesday, June 28, 2006, roads were closed at 138 locations throughout New York because of flooding, including approximately $275 \mathrm{mi}$ of the New York Interstate Highway System (New York State Department of Transportation, 2006). Thousands of people were asked to evacuate their homes because of rising floodwaters in New York, New Jersey, and Pennsylvania. U.S. National Guard and State helicopters were dispatched to rescue victims from their rooftops as the floodwaters washed out roads and damaged homes and businesses. On July 1, 2006, the head of the Department of Homeland Security, Federal Emergency Management Agency (FEMA), announced that a major disaster had been declared for New York to supplement State and local recovery efforts in the areas struck by severe storms 
and flooding that began on June 26, 2006 (Federal Emergency Management Agency, 2006). Twelve counties in New York were named in the disaster declaration, and by July 6, 2006, more than 3,200 individuals had registered for disaster assistance. On July 12, 2006, \$2.2 million was initially approved to assist flood victims in New York with housing.

Nearly $\$ 30$ million was approved for disaster assistance by July 25,2006 . The initial $\$ 2.2$ million in disaster assistance for housing was increased to $\$ 16.2$ million, $\$ 10.4$ million was added for low-interest loans to homeowners, and additional funding of about $\$ 3.1$ million was approved for other needs and assistance. More than 15,500 individuals had applied for assistance by December 18, 2006. On December 29, 2006, FEMA announced that more than \$227 million had been approved or obligated for assistance to residents and businesses for disaster-related expenses not covered by insurance and for State and local agencies to repair flood damages and rebuild infrastructure damaged during the flood (Federal Emergency Management Agency, 2006). The USGS, in cooperation with FEMA, conducted a study to characterize the effects of the 4-day storm.

This report documents the flooding in the Mohawk, Delaware, and Susquehanna River basins in New York. Included in this report are rainfall data, reservoir watersurface elevations, discharge hydrographs, peak discharges, and updated flood-frequency data for selected USGS streamgaging stations. This report also documents peak water-surface elevations at 29 USGS stream-gaging stations and 104 study sites along the Mohawk River and selected tributaries; the East, West, and main branches of the Delaware River and selected tributaries downstream to Port Jervis, NY; and the Susquehanna River and selected tributaries downstream to Athens, PA. Rainfall amounts, streamflow discharges, updated flood frequencies, and water-surface elevations for streams and reservoirs are presented in figures and tables. Peak surface-water elevations and peak discharges are compared to those of historical floods. FEMA personnel, in cooperation with the USGS, selected the 104 study sites in the Mohawk, Delaware, and Susquehanna River basins included in this report. Peak water-surface elevations were surveyed, described, and photographed by USGS and URS Corporation personnel. Descriptions and maps of individual sites are presented in Appendix 1. Comparisons of peak watersurface elevations at selected study sites in the Delaware River basin between the September 2004 and the June 2006 floods are shown in Appendix 2. Photographs of flood damage to selected areas in the Mohawk, Delaware, and Susquehanna River basins are shown in Appendix 3. Peak water-surface elevations at many study sites exceeded the 100 -year floodprofile elevations and at some study sites exceeded the 500 -year flood-profile elevations as documented in floodinsurance studies by FEMA. Peak-of-record discharges were recorded at several USGS stream-gaging stations in each of the studied basins.

\section{Storm of June 26-29, 2006}

\section{Antecedent Conditions}

Prior to June 2006, streamflow conditions in the Mohawk and Delaware River basins were generally in the normal range, and streamflow conditions in the Susquehanna River basin were in the dry range. The NWS reported precipitation totals for May 2006 that ranged from 25 to 95 percent of normal across parts of the lower Delaware and Susquehanna River basins. Precipitation in the Mohawk and Hudson River basins ranged from 25 to more than 100 percent of normal for the month of May 2006 (National Oceanic and Atmospheric Administration, 2006d). Storm activity started to pick up during the first part of June with numerous storm systems moving across the State of New York. Widespread rainfall from these systems was generally less than 0.75 in.; however, a couple of storms produced about 1.5 in. of rainfall in several broad areas in western and southeastern New York. The period of June 16-22, 2006, was relatively calm with respect to precipitation. Rainfall amounts across the three basins were generally less than 0.50 in.

\section{Precipitation}

The daily mean flow at the USGS stream-gaging stations Mohawk River at Little Falls, West Branch Delaware River at Walton, and the Susquehanna River at Conklin were in the normal range on June 1, 2006. The daily mean flow on June 1, 2006, at the USGS stream-gaging station East Branch Delaware River at Margaretville was at a level exceeded less than 10 percent of the time. On Friday, June 23, a cold front moved through Pennsylvania, New Jersey, and southeastern New York. Rainfall totals from this event were light to moderate, but this weather pattern continued into the following week. Rain increased on June 25 into June 26 with daily rainfall totals of 1 to 3 in. reported in southeastern New York. On Tuesday, June 27, a frontal boundary characterized by low pressure was centered over the Midwest, and a high pressure system centered off of the southern coast of New Jersey stalled over the region. The opposite rotations of these two systems worked together to channel tropical moisture northward directly over central New York and the Susquehanna, Delaware, and Mohawk River basins. Heavy rains spread from south to north across New York from June 26 through June 29, 2006. Cumulative 4-day rainfall totals across New York ranged from less than 2 in. to greater than 12 in. (fig. 1A) and daily rainfall totals for June 26 to June 29 ranged from less than 1 in. to greater than 6 in. (fig. 1B).

This storm system produced widespread rainfall amounts of greater than $5 \mathrm{in}$. in the three basins; isolated areas received rainfall in excess of 10 in. in a 4-day period. Rainfall amounts for the storm of June 26-29 at selected sites in the Mohawk, 


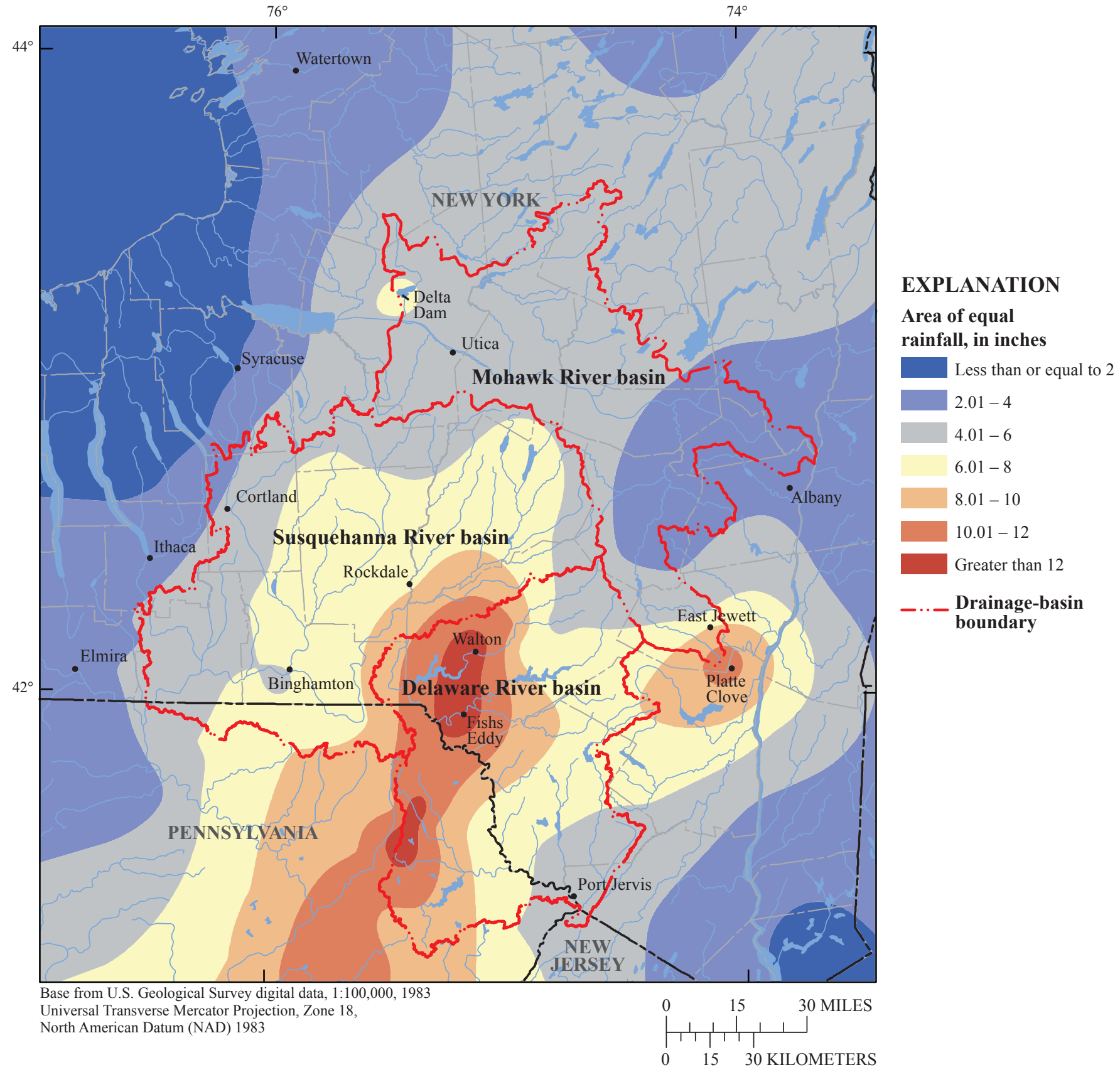

Figure 1A. Cumulative 4-day rainfall for the storm of June 26-29, 2006, and pertinent geographic features of New York. 

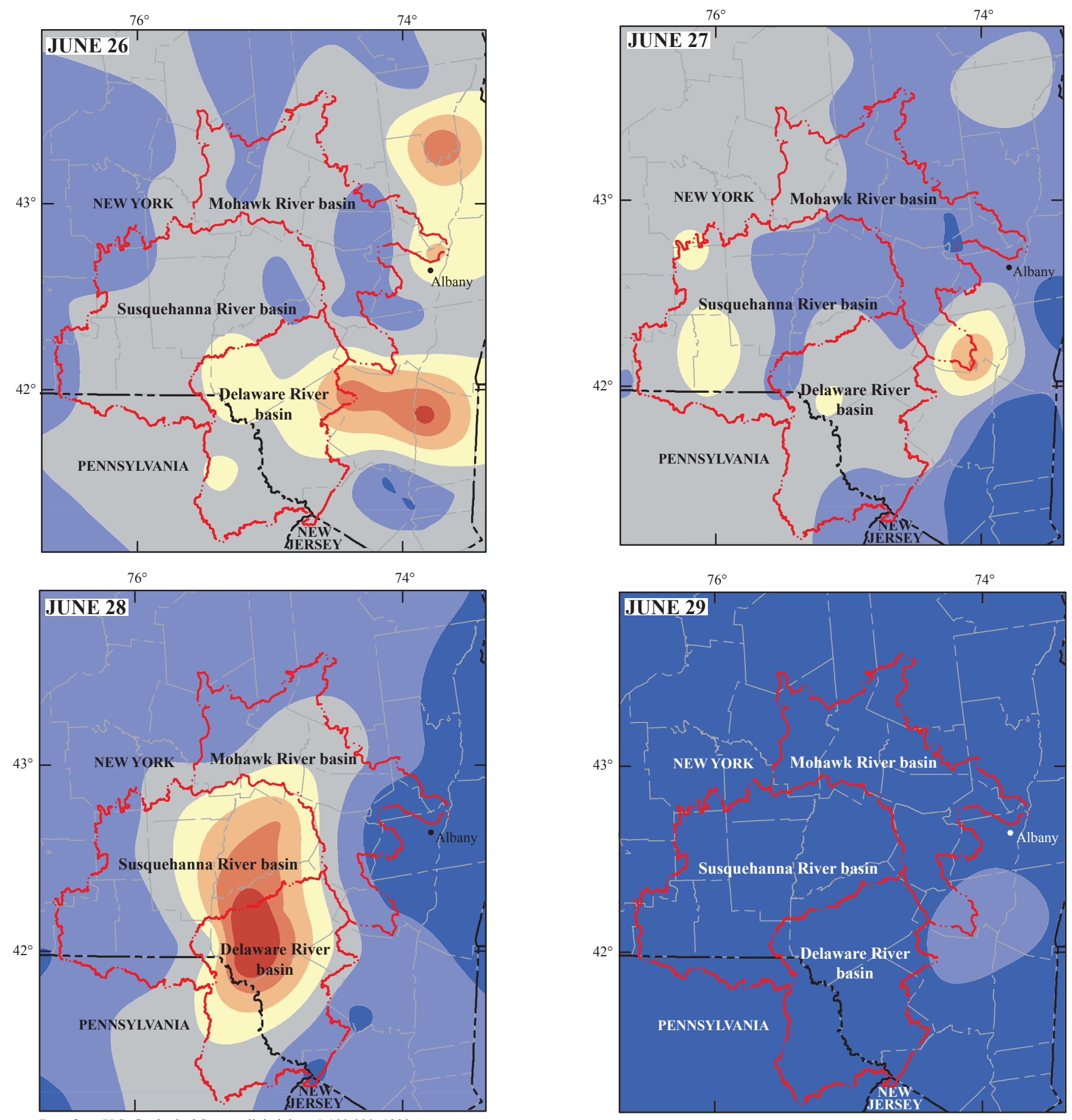

Base from U.S. Geological Survey digital data, 1:100,000, 1983 Universal Transverse Mercator Projection, Zone 18, North American Datum (NAD) 1983

\section{EXPLANATION}

Area of equal rainfall, in inches

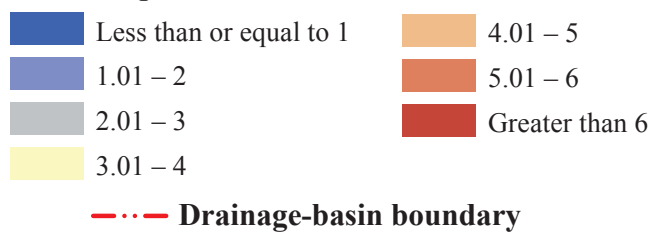

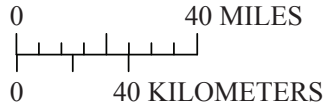

Figure 1B. Daily rainfall totals for the storm of June 26-29, 2006, and pertinent geographic features of New York. 


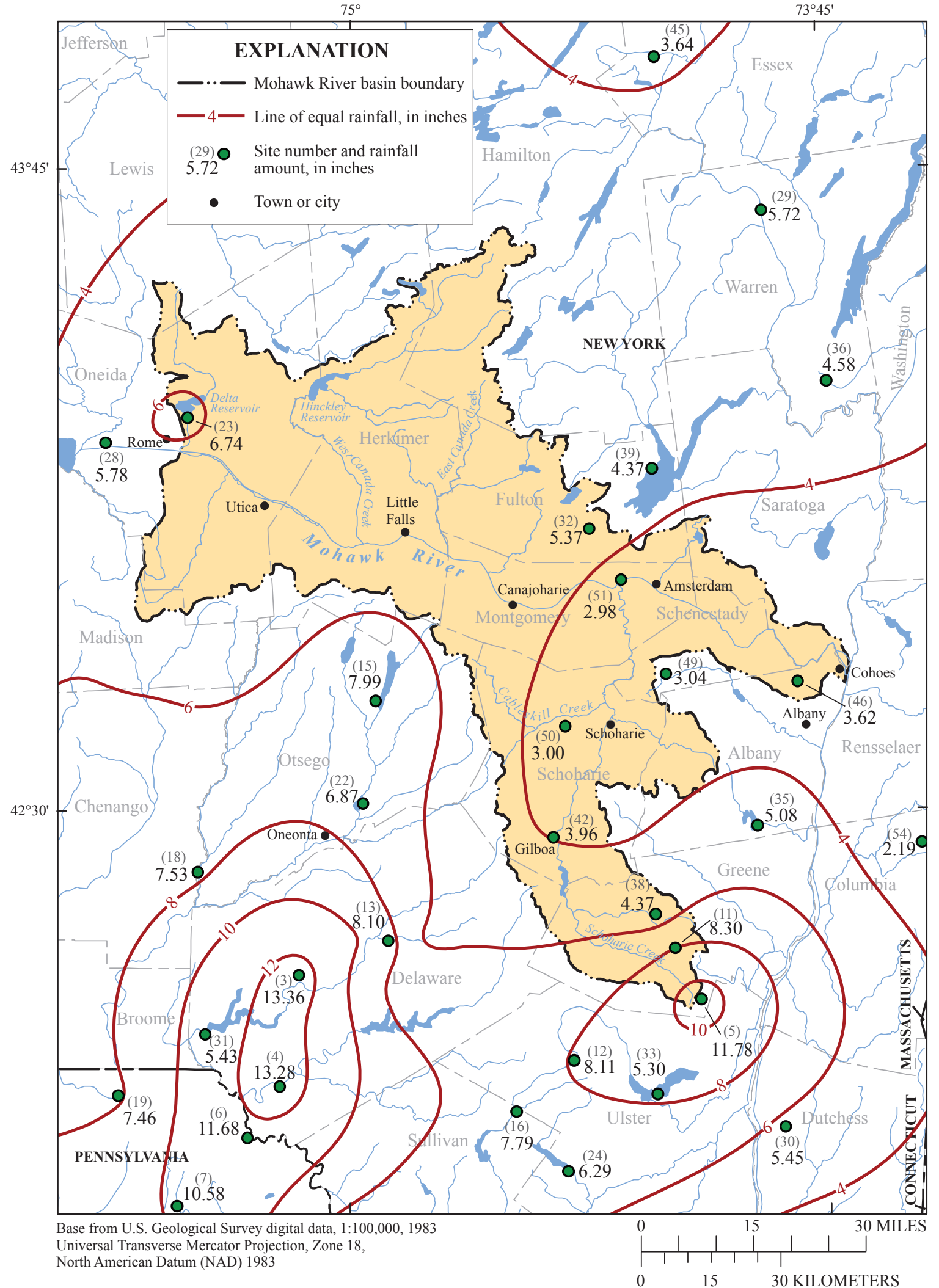

Figure 1C. Total rainfall in the Mohawk River basin, NY, and surrounding area for the storm of June 26-29, 2006. (Precipitation sites listed in table 1. Additional National Weather Service rainfall data and provisional spotter rainfall data used to develop map.) 


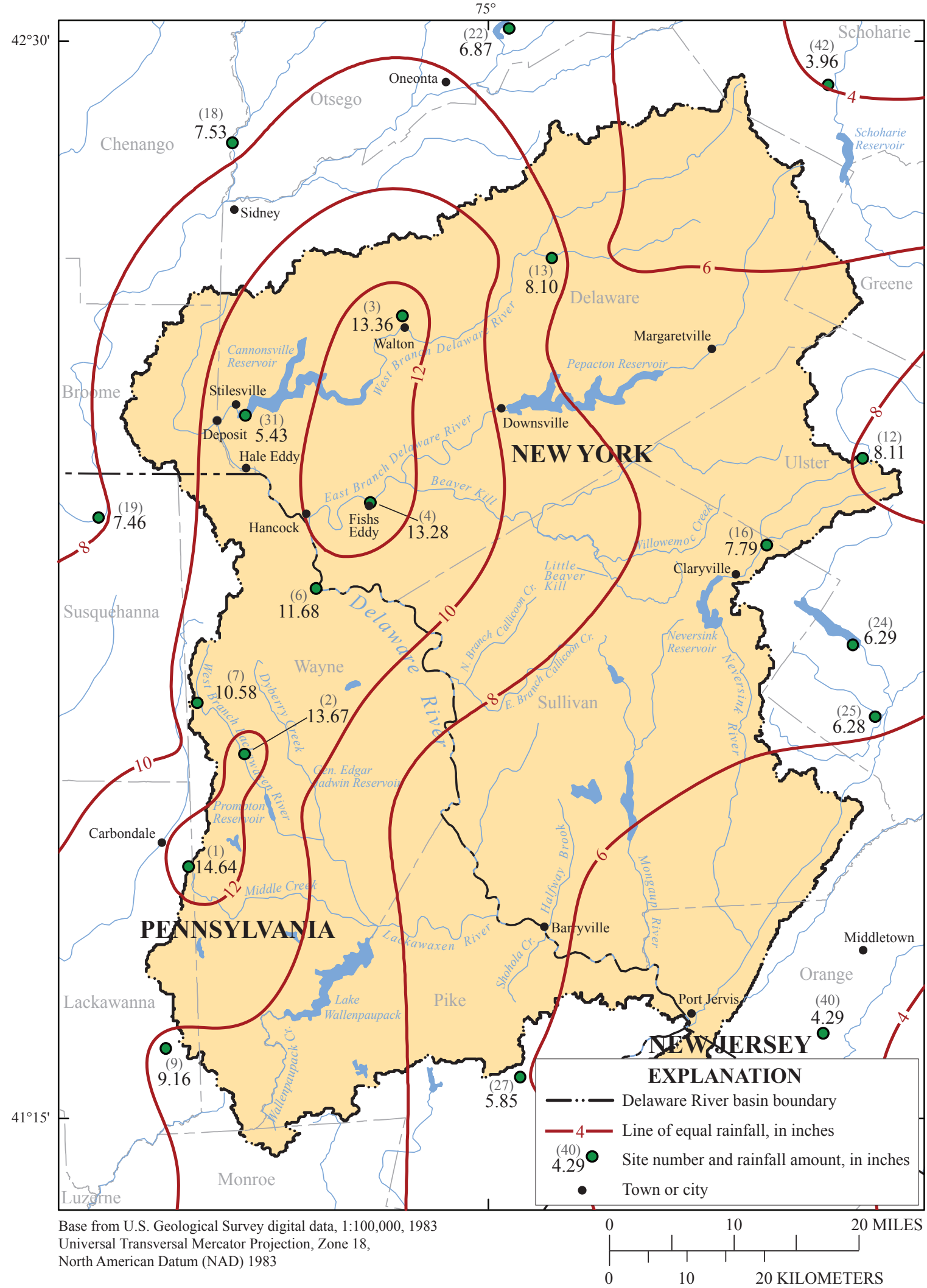

Figure 1D. Total rainfall in the Delaware River basin, NY, and surrounding area for the storm of June 26-29, 2006. (Precipitation sites listed in table 1. Additional National Weather Service rainfall data and provisional spotter rainfall data used to develop map.) 


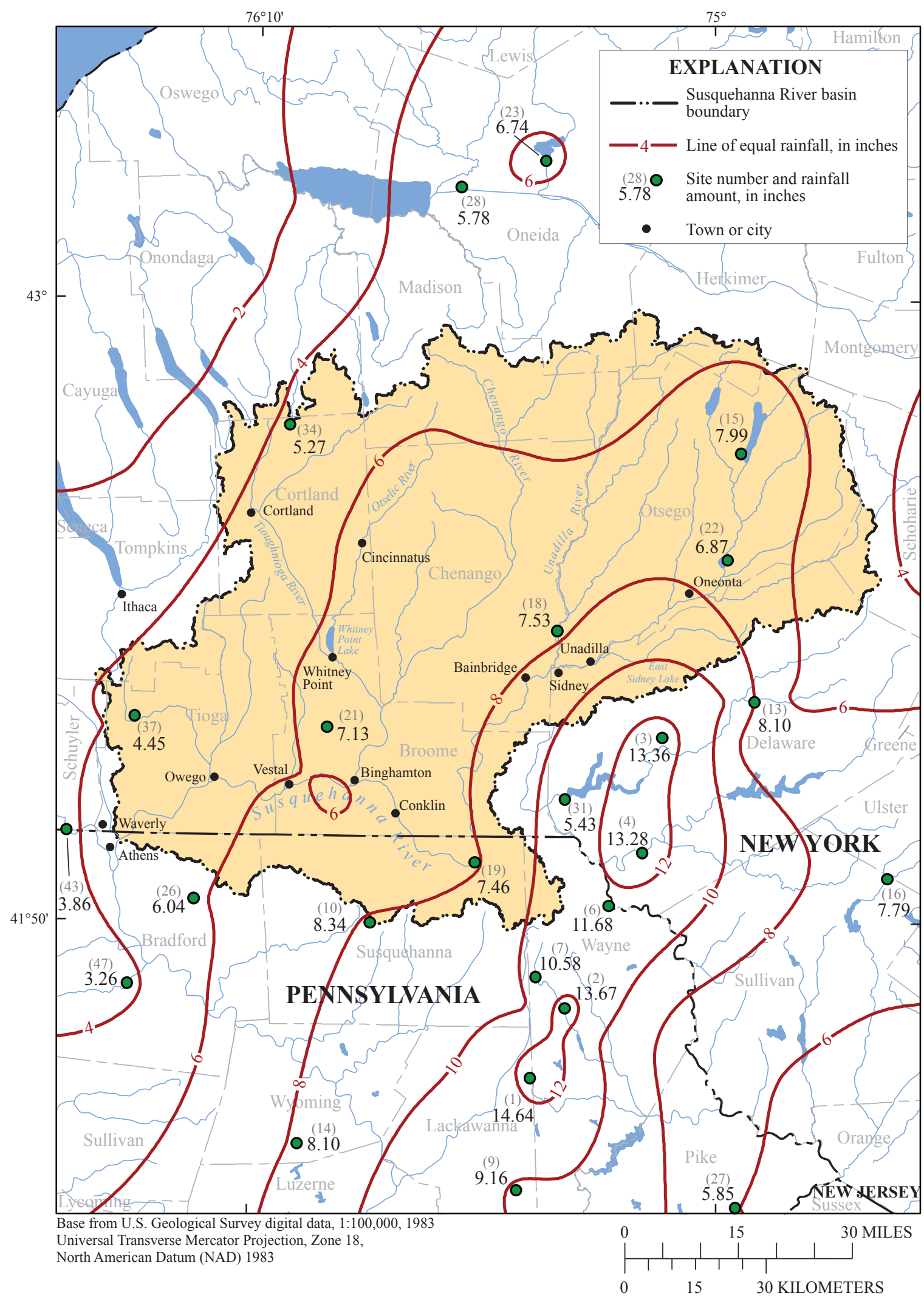

Figure1E. Total rainfall in the Susquehanna River basin, NY, and surrounding area for the storm of June 26-29, 2006. (Precipitation sites listed in table 1. Additional National Weather Service rainfall data and provisional spotter rainfall data used to develop map.) 
Delaware, and Susquehanna River basins are shown in figures $1 \mathrm{C}-\mathrm{E}$.

Cumulative hourly data recorded at the NWS precipitation station in Claryville, NY, describe a moderately heavy rain in the late morning hours on June 26 , then a sustained rain through June 27 (fig. 2A). A heavy burst of rain was recorded from late in the evening on June 27 through the first 8 hours of June 28. This period of heavy rain increased the rainfall total for this storm from about $4.5 \mathrm{in}$. late in the day on June 27 to more than 7.5 in. by noon on June 28 at the NWS station at Claryville, NY.

Precipitation data for the NWS station at Binghamton, NY, indicate slightly different timing, but a similar rainfall pattern (fig. 2B). Recorded rainfall at Binghamton indicated a rather sharp increase in rainfall from near midnight on June 26 into the early morning hours of June 27 , then a fairly slow and intermittent rain until early evening on June 27. A heavy and fairly constant period of rain was recorded from early evening on June 27 through the morning of June 28. Rainfall totals at Binghamton increased from less than 4 in. to more than 6.5 in. from June 27 to the morning of June 28.

The New York City Department of Environmental Protection (NYCDEP) recording station at the Cannonsville Reservoir recorded just over 4.4 in. of rainfall from June 26 to 29 and a total of almost 6 in. for the period of June 23-29 (fig. 2C). Additional NWS and NYCDEP precipitation stations recorded storm totals of greater than 13 in. at Walton and Fishs Eddy, NY; greater than 10 in. near Ashland, NY; greater than 7 in. at Sherburne, NY; and greater than 3.5 in. at Lansing Manor and Albany, NY (fig. 2D). Total rainfall amounts at 55 selected locations in New York are listed in table 1.

Daily rainfall totals for June 27 exceeded 5 in. at Platte Clove, 4.6 in. at East Jewett, and 4 in. at Binghamton and Delta Dam, NY (figs. 1A, 1B). On June 28 daily rainfall totals exceeded 5 in. at Rockdale, NY. Rainfall frequencies for these daily totals were estimated to have a recurrence interval of about 10 years at Platte Clove, between 5 and 10 years at Binghamton and East Jewett, from 10 to 25 years at Delta Dam, and about 50 years at Rockdale (U.S. Weather Bureau, 1961). On June 28, the largest 1-day rainfall totals in the State of New York for this storm were recorded at Walton and Fishs Eddy, NY. The NWS reported rainfall totals of 9.63 and 8.34 in. on June 28 at Walton and Fishs Eddy (National Oceanic and Atmospheric Administration, 2006b) (fig. 1B). The rainfall frequencies for these two stations exceeded the 24-hour 100-year recurrence interval (U.S. Weather Bureau, 1961). The 4-day rainfall total at Binghamton is between the 4-day 50-year and the 4-day 100-year recurrence intervals, but the 4-day rainfall totals of greater than 13 in. for Fishs Eddy and Walton exceeded the 4-day 100-year recurrence interval (U.S. Weather Bureau, 1964). Heavy rain from June 26 to June 29, 2006, produced period-of-record flooding that superseded the previous records set by the 1936, 1955, 1972, and the 1996 storms at the Mohawk River at Little Falls, the West Branch Delaware River at Walton, and the Susquehanna River at Conklin stream-gaging stations. Rainfall frequencies for selected sites are listed in tables $2 \mathrm{~A}$ and $2 \mathrm{~B}$.

Prolonged rainfall events in previous years also resulted in record-setting floods in New York and the surrounding region. Extended precipitation patterns in March 1936 produced record flooding in the Hudson, Delaware, and Susquehanna River basins. The floods of March 1936 were caused by precipitation during March 9-22, a period of warming temperatures, when much of the topography was snow covered and rivers were still ice covered. This event was categorized as one long precipitation event having two periods of concentrated heavy rain. Rain and snow during March 9-10 were followed by heavier rains during March 11-13. Precipitation amounts from the first half of this storm event were generally in the 2 -in. range across the Delaware and Susquehanna River basins. Heavy precipitation from the second half of this storm event began around March 16 and continued through March 19, producing an additional 2 to as much as 6 in. of precipitation in the Delaware and Susquehanna River basins by March 22. The precipitation from this extended event caused record-breaking or extraordinary flooding in the Hudson, Delaware, and Susquehanna River basins. Records set in March 1936 at several USGS stream-gaging stations along the Susquehanna River remained until they were superseded by the June 2006 flood. Total rainfall amounts for the March 9-22, 1936, precipitation event are presented in figure $3 \mathrm{~A}$.

The floods from Hurricanes Connie and Diane in August 1955 were also produced by two back-to-back precipitation events. Heavy rains from Hurricane Connie produced rainfall totals of 3 to more than $7 \mathrm{in}$. during August 11-14, 1955. Hurricane Diane added an additional 2 to 9 in. of rain in southeastern New York during August 17-20, 1955. Period-of-record maximums were set at several USGS stream-gaging stations along the main stem of the Delaware River from near Barryville, NY, downstream to Trenton, NJ.

The floods resulting from Hurricane Agnes was produced by an extended period of precipitation during June 19-23, 1972 (fig. 3B). This storm produced rainfall totals of 3 to greater than 12 in. in many locations in southern New York. The heaviest rainfall in New York fell over parts of the Allegheny and Susquehanna River basins. Although at the time widespread flooding was recorded at many stations in southern New York, major flooding at the headwaters of the Susquehanna River upstream from Vestal, NY, did not occur as a result of this storm. Flooding in the Chemung River basin and downstream from the confluence of the Chemung and Susquehanna Rivers near the New York and Pennsylvania border to the Chesapeake Bay was considered to be the greatest flood known since 1784 (Bailey and others, 1975). 


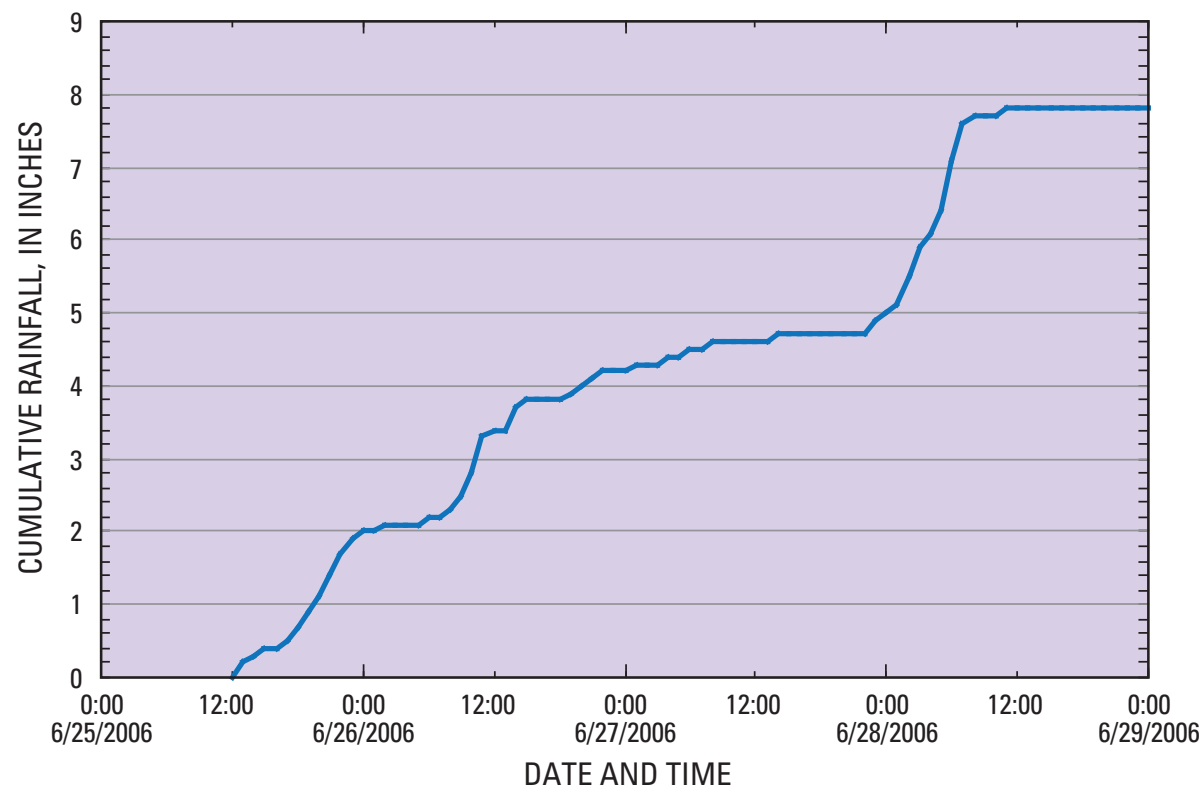

Figure 2A. Cumulative hourly rainfall during June 25-28, 2006, recorded at the National Weather Service hourly recording station at Claryville, NY. (Location shown in figs. 1D.)

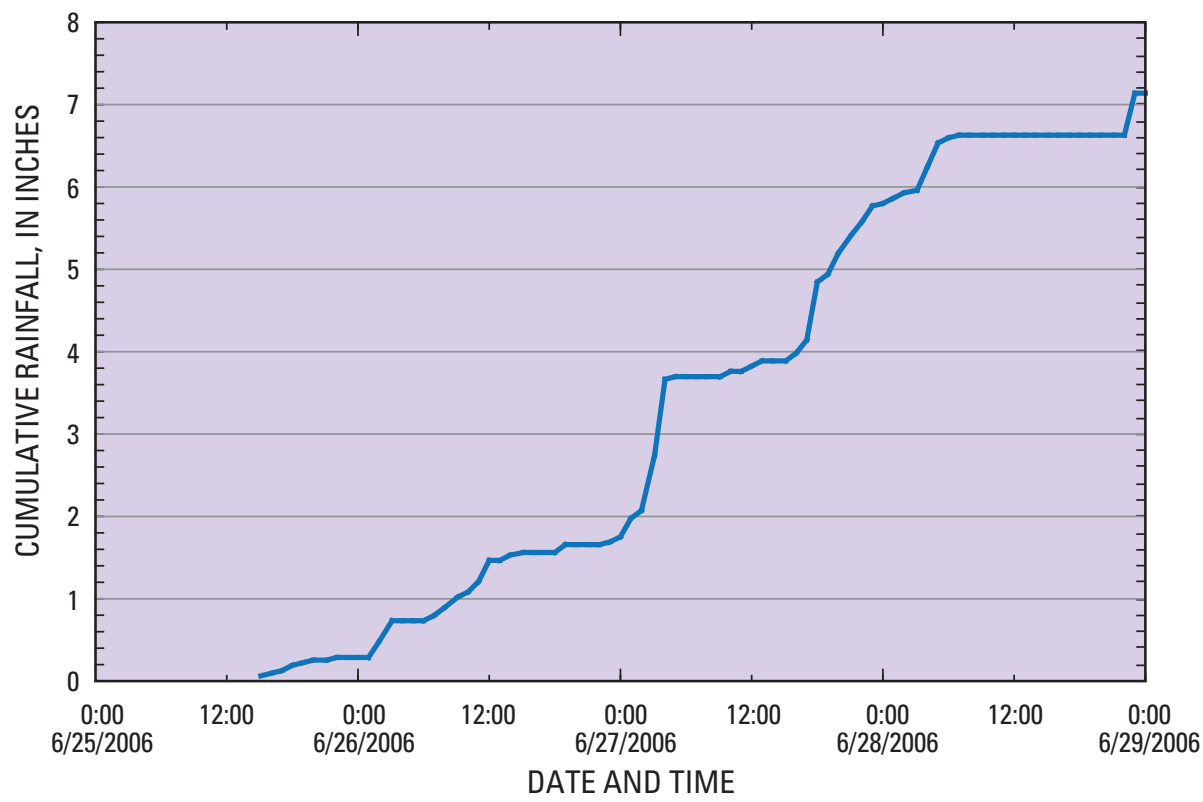

Figure 2B. Cumulative hourly rainfall during June 25-28, 2006, recorded at the National Weather Service office at Binghamton, NY. (Location shown in figs. 1E.) 


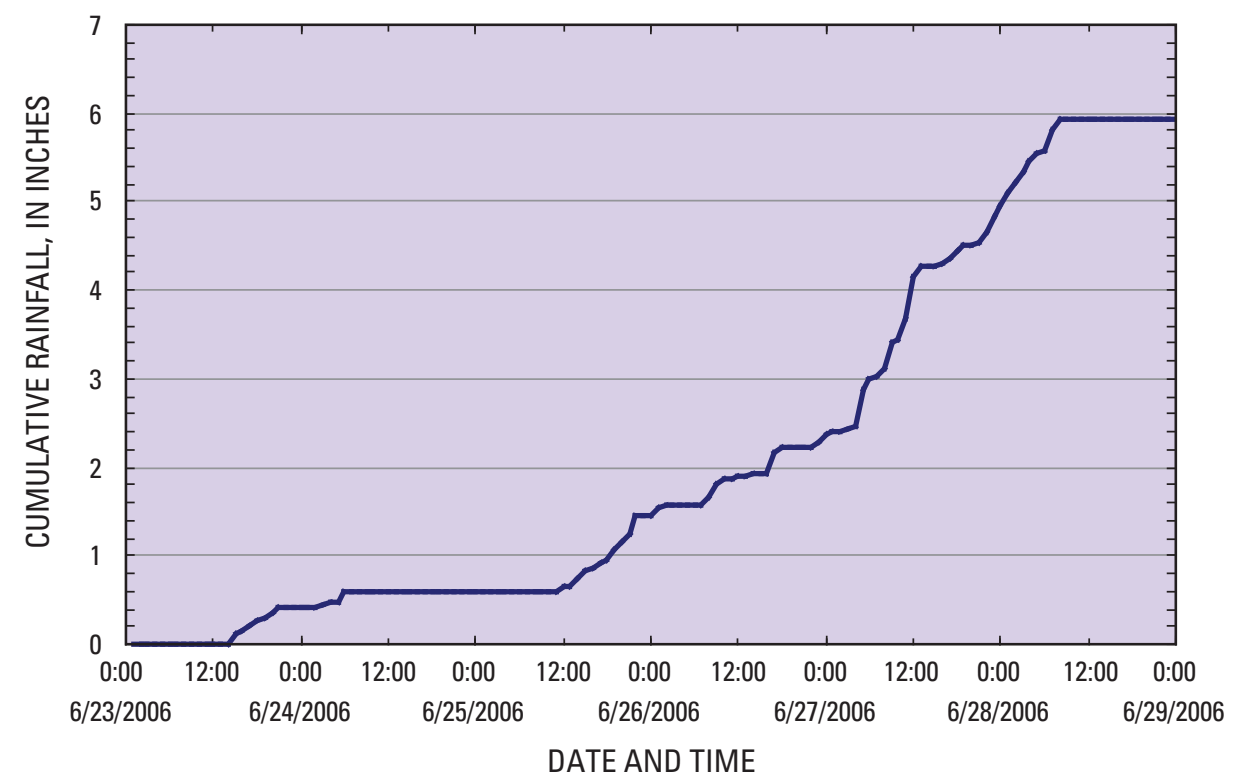

Figure 2C. Cumulative hourly rainfall during June 23-28, 2006, recorded at the New York City Department of Environmental Protection station at Cannonsville Reservoir, NY. (Location shown in figs. 1D.)

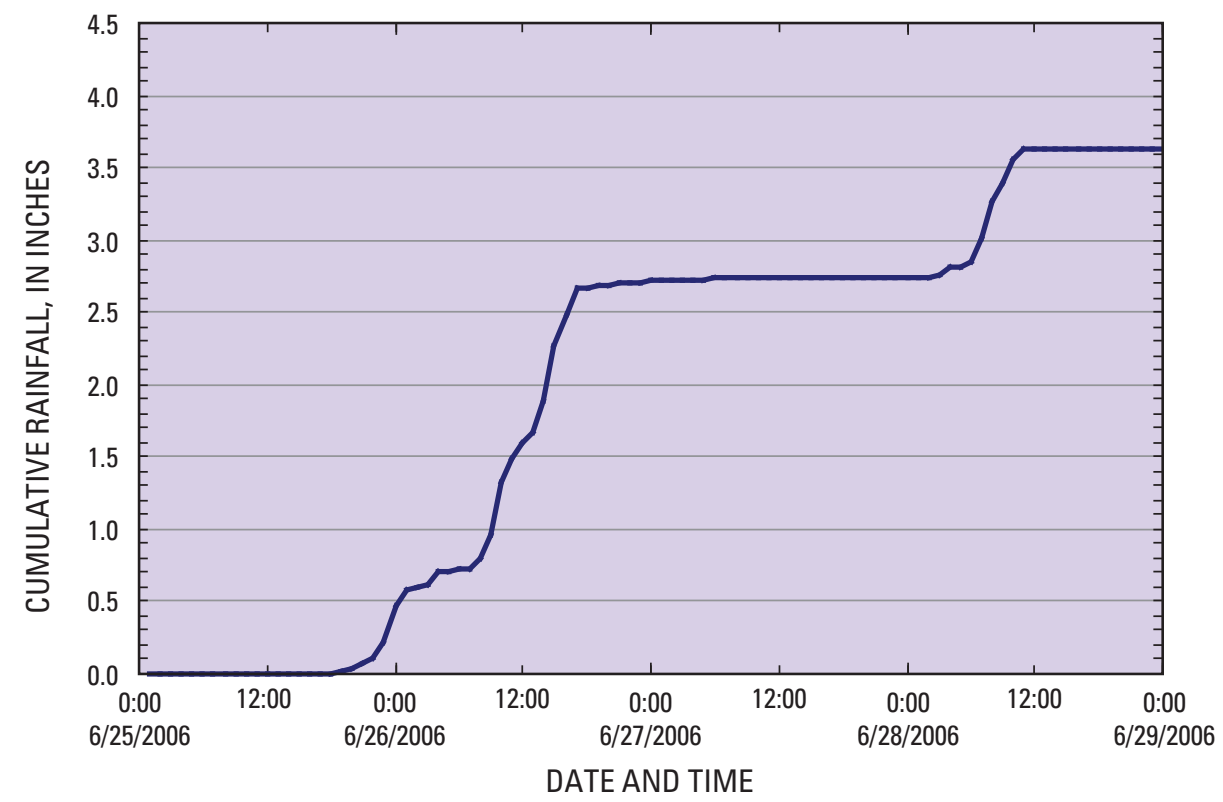

Figure 2D. Cumulative hourly rainfall during June 25-28, 2006, recorded at Albany International Airport, NY. (Location shown in figs. 1B, 1C.) 
Table 1. Total rainfall for the storm of June 26-29, 2006, at selected locations in New York and surrounding areas.

[Data provided by National Oceanic and Atmospheric Administration (2006a) and New York City Department of Environmental Protection (written commun. 2007); selected data shown in fig. 1C-E]

\begin{tabular}{|c|c|c|}
\hline Site number & Site name & $\begin{array}{c}\text { Total rainfall } \\
\text { (inches) }\end{array}$ \\
\hline 1 & WDCL Radio Tower, PA & 14.64 \\
\hline 2 & Aldenville, PA & 13.67 \\
\hline 3 & Walton, NY & 13.36 \\
\hline 4 & Fishs Eddy, NY & 13.28 \\
\hline 5 & Platte Clove, NY & 11.78 \\
\hline 6 & Equinunk, PA & 11.68 \\
\hline 7 & Pleasant Mount, PA & 10.58 \\
\hline 8 & Frost Valley, NY & 9.57 \\
\hline 9 & Moscow, PA & 9.16 \\
\hline 10 & Montrose, PA & 8.34 \\
\hline 11 & East Jewett, NY & 8.30 \\
\hline 12 & Slide Mountain, NY & 8.11 \\
\hline 13 & Delhi, NY & 8.10 \\
\hline 14 & Noxen, PA & 8.10 \\
\hline 15 & Cooperstown, NY & 7.99 \\
\hline 16 & Claryville, NY & 7.79 \\
\hline 17 & Chichester NY & 7.58 \\
\hline 18 & Rockdale, NY & 7.53 \\
\hline 19 & Susquehanna, PA & 7.46 \\
\hline 20 & Grahamsville, NY & 7.23 \\
\hline 21 & Binghampton WSO, NY & 7.13 \\
\hline 22 & Maryland $6 \mathrm{SW}, \mathrm{NY}$ & 6.87 \\
\hline 23 & Delta Dam, NY & 6.74 \\
\hline 24 & Rondout Reservoir, NY & 6.29 \\
\hline 25 & Ellenville, $\mathrm{NY}$ & 6.28 \\
\hline 26 & Orwell, PA & 6.04 \\
\hline 27 & Dingman, PA & 5.85 \\
\hline 28 & New London Lock 22, NY & 5.78 \\
\hline 29 & North Creek, NY & 5.72 \\
\hline 30 & Rhinebeck, NY & 5.45 \\
\hline 31 & Cannonsville Reservoir, NY & 5.43 \\
\hline 32 & Gloversville, NY & 5.37 \\
\hline 33 & Ashokan Reservoir, NY & 5.30 \\
\hline 34 & Tully Hebring Forest, NY & 5.27 \\
\hline 35 & Alcove Dam, NY & 5.08 \\
\hline 36 & Glens Falls Farm, NY & 4.58 \\
\hline 37 & Spencer, NY & 4.45 \\
\hline 38 & Windham, NY & 4.37 \\
\hline 39 & Northville, NY & 4.37 \\
\hline 40 & Gardnerville, NY & 4.29 \\
\hline
\end{tabular}


Table 1. Total rainfall for the storm of June 26-29, 2006, at selected locations in New York and surrounding areas. —Continued

[Data provided by National Oceanic and Atmospheric Administration (2006a) and New York City Department of Environmental Protection (written commun. 2007); selected data shown in fig. 1C-E]

\begin{tabular}{cll}
\hline Site number & \multicolumn{1}{c}{ Site name } & \multicolumn{1}{c}{$\begin{array}{c}\text { Total rainfall } \\
\text { (inches) }\end{array}$} \\
\hline 41 & Whitehall, NY & 3.98 \\
42 & Lansing Manor, NY & 3.96 \\
43 & Chemung, NY & 3.86 \\
44 & Schoharie Reservoir, NY & 3.72 \\
45 & Newcomb, NY & 3.6 \\
46 & Albany INTL AP, NY & 3.62 \\
47 & Monroeton, PA & 3.26 \\
48 & Poughkeepsie, NY & 3.10 \\
49 & Delanson 2Ne, NY & 3.04 \\
50 & Cobleskill, NY & 3.00 \\
51 & Tribes Hill, NY & 2.98 \\
52 & West Point, NY & 2.97 \\
53 & Carmel, NY & 2.42 \\
54 & East Chatham, NY & 2.19 \\
55 & Yorktown Heights, NY & 1.33 \\
\hline
\end{tabular}

\section{Flood of June 27-29, 2006, Discharge and Frequency}

The location of the three major basins studied in this report and selected USGS stream-gaging stations are presented in figure 4. Historic flood peaks and peak discharges during the June 2006 flood at 76 USGS stream-gaging stations are presented in table 3 .

Frequency analysis of annual flood-peak data recorded at stream-gaging stations provides a means of estimating the probability of occurrence of a given discharge. Flood frequency is commonly expressed in terms of recurrence interval or the probability of being exceeded (one is the reciprocal of the other). The 100-year flood, for example, has a probability of 0.01 (1-percent chance) of being equaled or exceeded in any given year.

Recurrence intervals for stream-gaging stations listed in this report were calculated by fitting annual peak-discharge data to a log-Pearson type III distribution (Interagency Advisory Committee on Water Data, 1982). The results of this analysis were weighted with the results of the regional flood-frequency analysis (Lumia, 2006) at stream-gaging stations with unregulated streamflows. Recurrence intervals at stream-gaging stations with substantial regulation were calculated from statistical analyses of annual peak discharges during the regulated period only, except along the main stem of the Delaware River from Callicoon, NY, to Montague, NJ. No adjustments were made for the amount of available storage in the reservoirs before or during floods, or for changes in regulation procedures during the period of regulation. Recurrence intervals at stream-gaging stations along the main stem of the Delaware River from Callicoon, NY, to Montague, NJ, were computed by fitting systematic annual peak-discharge data to a log-Pearson type III distribution for the entire period of record (Schopp and Firda, 2008).

Peak discharges recorded during the June 2006 flood at several of the USGS stream-gaging stations listed in table 3 had recurrence intervals of less than 25 years. Stream-gaging stations at the Hudson River at Hadley (01318500), and Esopus Creek at Coldbrook (01362500) in the Hudson River basin; the East and West Branches of the Neversink River near Claryville (01434107 and 01434498) in the Delaware River basin; and the Tioughnioga River at Cortland (01509000) in the Susquehanna River basin all recorded peak discharges with recurrence intervals of less than 25 years. Substantial flooding and peak discharges with a greater than 100-year recurrence interval were recorded at several stations along the Mohawk, Delaware, and Susquehanna Rivers and on some of their major tributaries. Although widespread flooding did occur throughout the region, the increase in magnitude and frequency of peak discharges at several stream-gaging stations along the main branches of these rivers can be linked to major inflows from larger tributaries. (Details about peak discharges and flood frequency as a result of the June 2006 flood are discussed in the following sections.) Antecedent conditions, precipitation and runoff patterns, and basin characteristics all play a role in determining the peak 
Table 2A. Rainfall-frequency relations for storms of 3-, 6-, 12-, and 24-hour duration at selected locations in New York.

[Data from U.S. Weather Bureau, 1961. Locations are shown in fig. 1C-E]

\begin{tabular}{|c|c|c|c|c|c|c|c|}
\hline \multirow{2}{*}{$\begin{array}{c}\text { Site } \\
\text { number }\end{array}$} & \multirow{2}{*}{$\begin{array}{c}\text { Site } \\
\text { name }\end{array}$} & \multirow{2}{*}{ County } & \multirow{2}{*}{$\begin{array}{c}\begin{array}{c}\text { Recurrence } \\
\text { interval }\end{array} \\
\text { (years) }\end{array}$} & \multicolumn{4}{|c|}{ Rainfall, in inches for selected duration } \\
\hline & & & & 3 hours & 6 hours & 12 hours & 24 hours \\
\hline \multirow[t]{6}{*}{3} & Walton & Delaware & 2 & 1.7 & 2.0 & 2.4 & 2.8 \\
\hline & & & 5 & 2.2 & 2.6 & 3.2 & 3.6 \\
\hline & & & 10 & 2.4 & 2.9 & 3.7 & 4.5 \\
\hline & & & 25 & 2.9 & 3.6 & 4.3 & 5.0 \\
\hline & & & 50 & 3.2 & 3.9 & 4.8 & 5.8 \\
\hline & & & 100 & 3.4 & 4.5 & 5.3 & 6.8 \\
\hline \multirow[t]{6}{*}{4} & Fishs Eddy & Delaware & 2 & 1.7 & 2.1 & 2.6 & 2.9 \\
\hline & & & 5 & 2.3 & 2.7 & 3.4 & 3.8 \\
\hline & & & 10 & 2.5 & 3.1 & 3.9 & 4.7 \\
\hline & & & 25 & 3.0 & 3.8 & 4.8 & 5.2 \\
\hline & & & 50 & 3.4 & 4.1 & 5.0 & 5.9 \\
\hline & & & 100 & 3.6 & 4.7 & 5.8 & 6.9 \\
\hline \multirow[t]{6}{*}{16} & Claryville & Sullivan & 2 & 1.9 & 2.5 & 3.3 & 3.5 \\
\hline & & & 5 & 2.5 & 3.0 & 4.0 & 4.6 \\
\hline & & & 10 & 2.9 & 3.9 & 4.6 & 5.8 \\
\hline & & & 25 & 3.4 & 4.3 & 5.5 & 6.5 \\
\hline & & & 50 & 3.9 & 5.0 & 6.0 & 7.0 \\
\hline & & & 100 & 4.1 & 5.5 & 6.8 & 8.0 \\
\hline \multirow[t]{6}{*}{21} & Binghamton & Broome & 2 & 1.4 & 1.8 & 2.4 & 2.8 \\
\hline & & & 5 & 2.0 & 2.5 & 3.0 & 3.5 \\
\hline & & & 10 & 2.3 & 2.9 & 3.5 & 4.1 \\
\hline & & & 25 & 2.5 & 3.4 & 4.0 & 4.8 \\
\hline & & & 50 & 2.8 & 3.8 & 4.3 & 5.2 \\
\hline & & & 100 & 3.3 & 4.1 & 5.0 & 5.8 \\
\hline \multirow[t]{6}{*}{28} & Delta Dam & Oneida & 2 & 1.6 & 1.9 & 2.3 & 2.5 \\
\hline & & & 5 & 1.9 & 2.3 & 2.8 & 3.3 \\
\hline & & & 10 & 2.4 & 2.8 & 3.3 & 3.7 \\
\hline & & & 25 & 2.8 & 3.0 & 3.6 & 4.4 \\
\hline & & & 50 & 3.0 & 3.5 & 3.8 & 4.7 \\
\hline & & & 100 & 3.4 & 3.8 & 4.5 & 4.9 \\
\hline
\end{tabular}


Table 2B. Rainfall-frequency relations for storms of 4-day duration at selected locations in New York.

[Data from U.S. Weather Bureau, 1964. Locations are shown in fig. 1C-E]

\begin{tabular}{|c|c|c|c|c|c|c|c|c|}
\hline \multirow[t]{2}{*}{ Site number } & \multirow[t]{2}{*}{ Site name } & \multirow[t]{2}{*}{ County } & \multicolumn{6}{|c|}{$\begin{array}{l}\text { Rainfall, in inches for 4-day duration for selected recurrence intervals } \\
\text { ( years) }\end{array}$} \\
\hline & & & 2 & 5 & 10 & 25 & 50 & 100 \\
\hline 3 & Walton & Delaware & 4.1 & 5.0 & 5.9 & 7.0 & 7.8 & 8.8 \\
\hline 4 & Fishs Eddy & Delaware & 4.4 & 5.3 & 6.0 & 7.4 & 8.0 & 9.0 \\
\hline 16 & Claryville & Sullivan & 5.4 & 7.0 & 8.1 & 10.0 & 10.0 & 12.0 \\
\hline 21 & Binghamton & Broome & 3.9 & 4.8 & 5.5 & 6.4 & 6.9 & 7.8 \\
\hline 28 & Delta Dam & Oneida & 3.6 & 4.3 & 4.8 & 5.7 & 6.2 & 6.8 \\
\hline
\end{tabular}

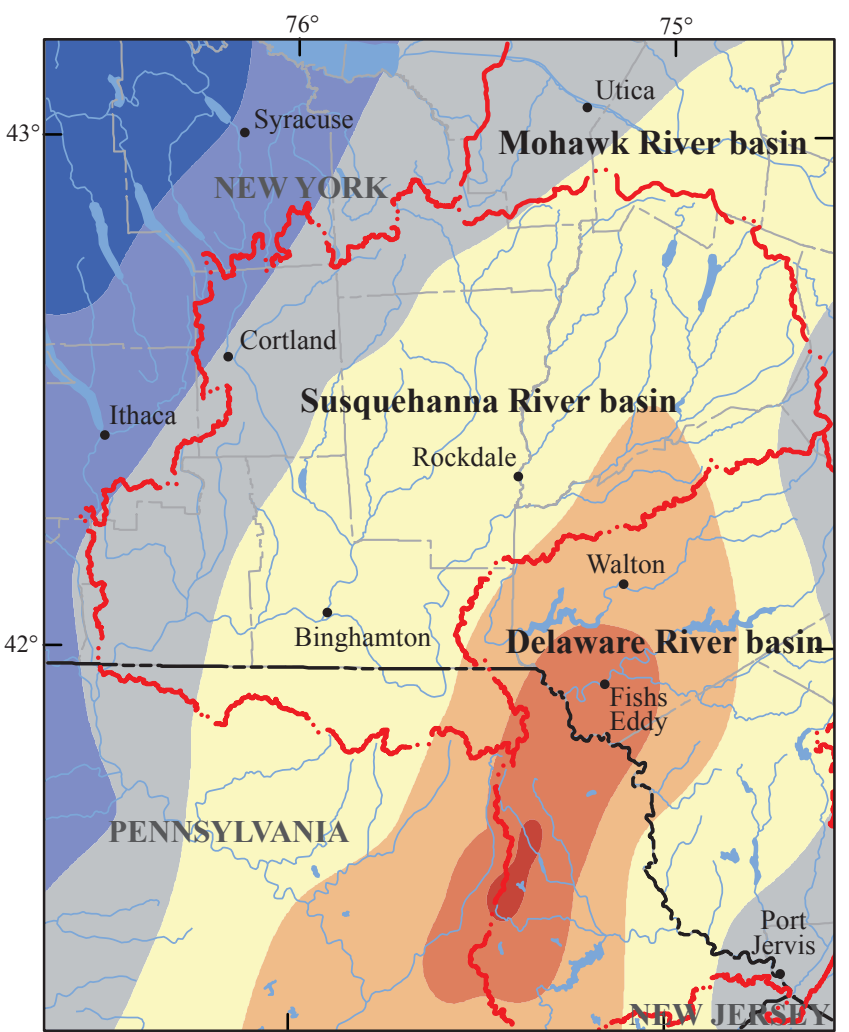

Base from U.S. Geological Survey digital data, 1:100,000, 1983 Universal Transverse Mercator Projection, Zone 18, North American Datum (NAD) 1983

\section{EXPLANATION}

Area of equal rainfall, in inches

Less than or equal to 2

$2.01-4$

$4.01-6$

$6.01-8$

$8.01-10$

$10.01-12$

Greater than 12

-..- Drainage-basin boundary

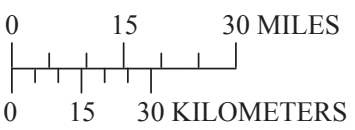

Figure 3A. Total precipitation in the Susquehanna River basin and surrounding area for the storms of March 9-22, 1936. 


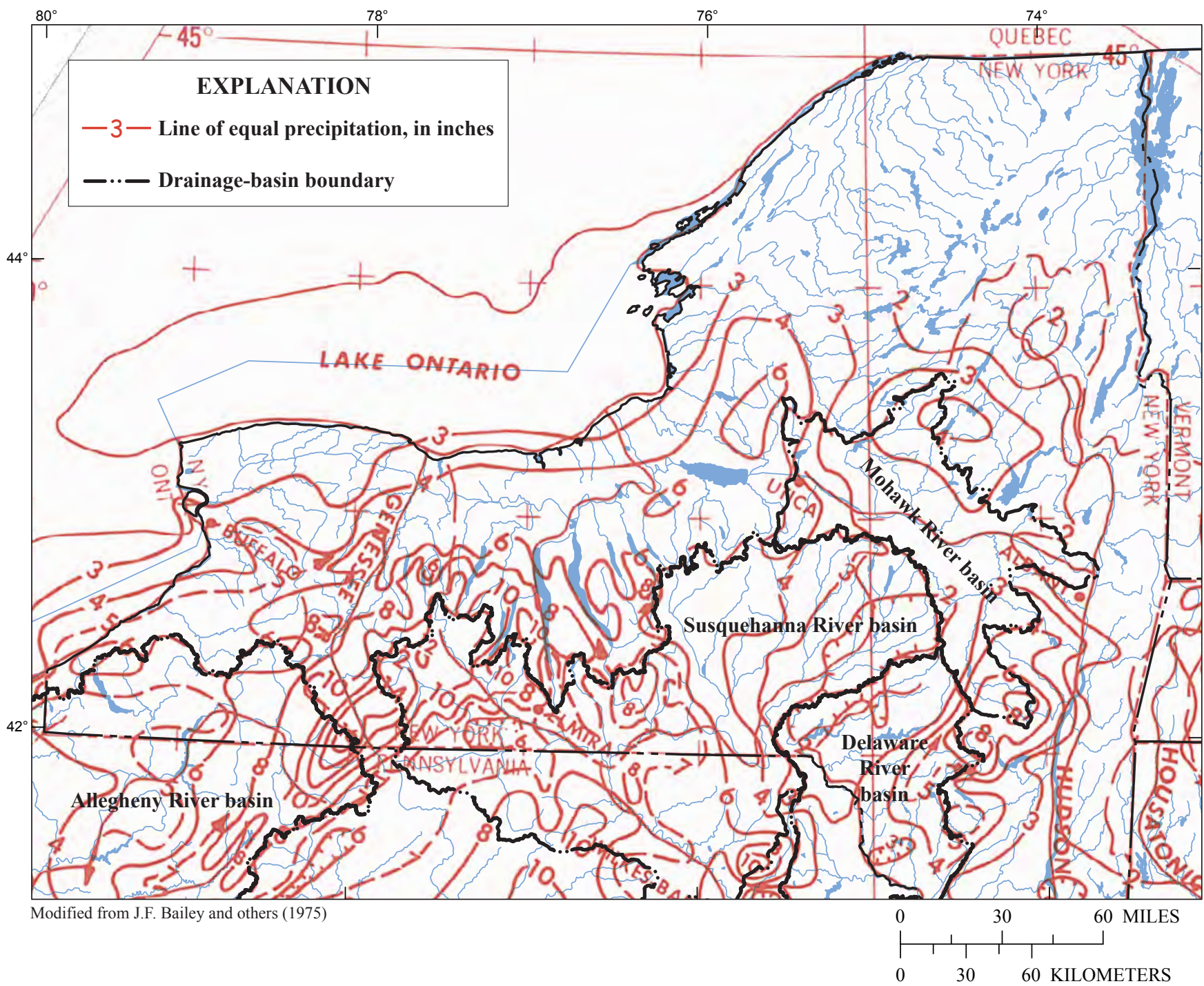

Figure 3B. Total rainfall in New York and surrounding area for the storm of June 19-23, 1972.

discharge at a stream-gaging station. Peak discharges for selected stream-gaging stations in the Hudson (contains the Mohawk River basin), Delaware, and Susquehanna River basins are plotted as a function of drainage area in figure 5 . The spatial distribution of peak discharge frequencies for selected USGS stream-gaging stations is presented in figure 6 . Annual peak discharges for the period of record through 2006, the recomputed 10-, 50-, and 100-year recurrence intervals, and a 10-year weighted moving average of annual peak discharges at 25 selected stream-gaging stations are presented in figure 7 . The weighted moving average of annual peak discharges is presented in figure 7 to show the general trend or pattern of yearly maximum flows (Helsel and Hirsch, 1992). The trend lines (weighted moving average) in figure 7 generally show the dryer periods of the 1960s and 1970s and the wetter periods of the 1980s, 1990s, and 2000s. At some of the stream-gaging stations immediately downstream from a reservoir, a reduction in the peak discharge is identifiable after the reservoirs began storage operations.

\section{Mohawk River Basin}

USGS stream-gaging stations along the Mohawk River near Rome (01336000) and Little Falls (01347000) recorded peak discharges on the morning of June 28, 2006 (fig. 8A-1). USGS stream-gaging stations on the East and West Canada Creeks, major tributaries to the Mohawk River, also recorded peak discharges on the morning of June 28, 2006. Farther downstream near the mouth of the Mohawk River at Cohoes (01357500), the peak discharge was recorded in the morning hours of June 29, 2006 (fig. 8A-1). 


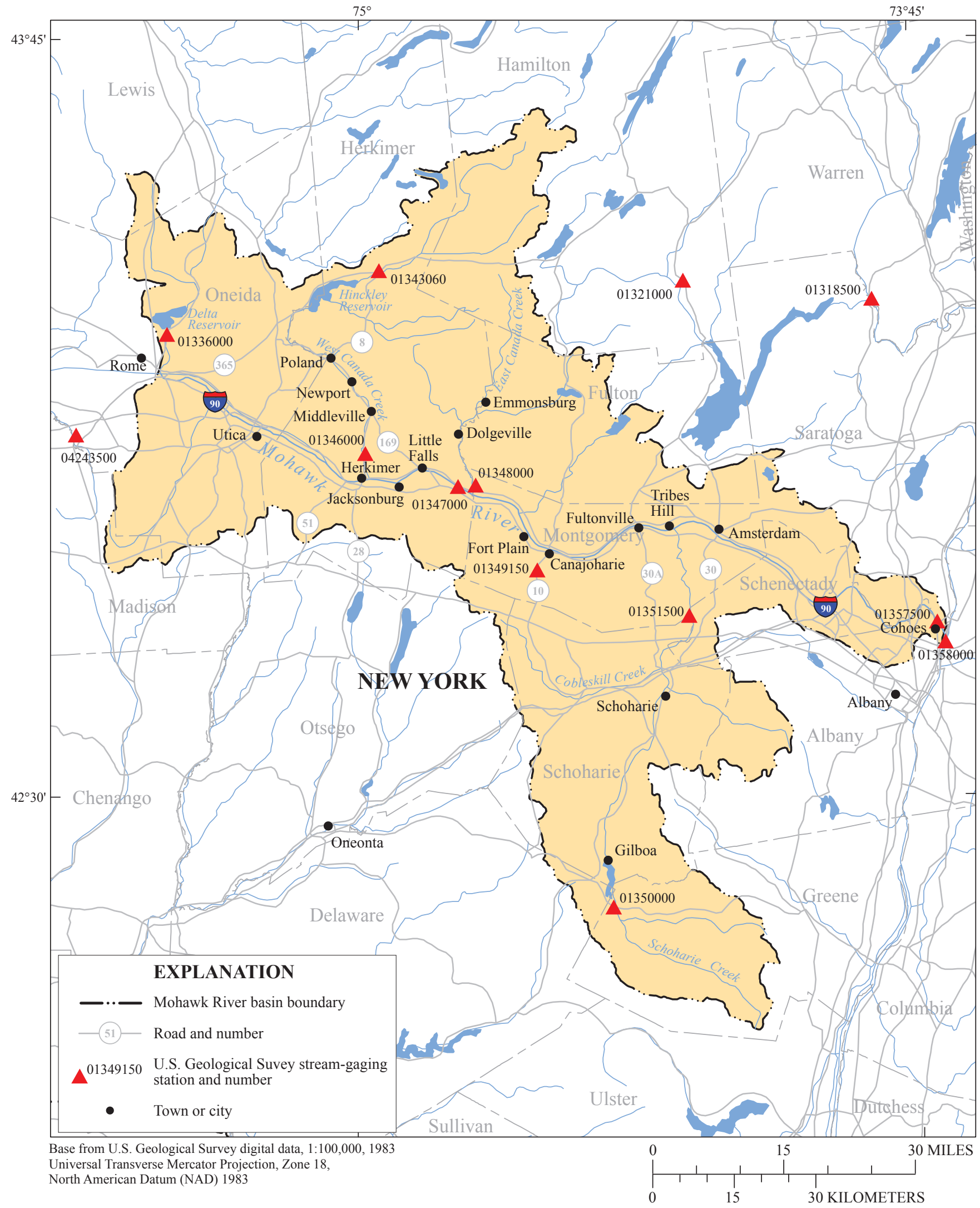

Figure 4A. Locations of selected U.S. Geological Survey stream-gaging stations in the Mohawk River basin, NY, and surrounding area. (Station names and flood-related data listed in table 3.) 


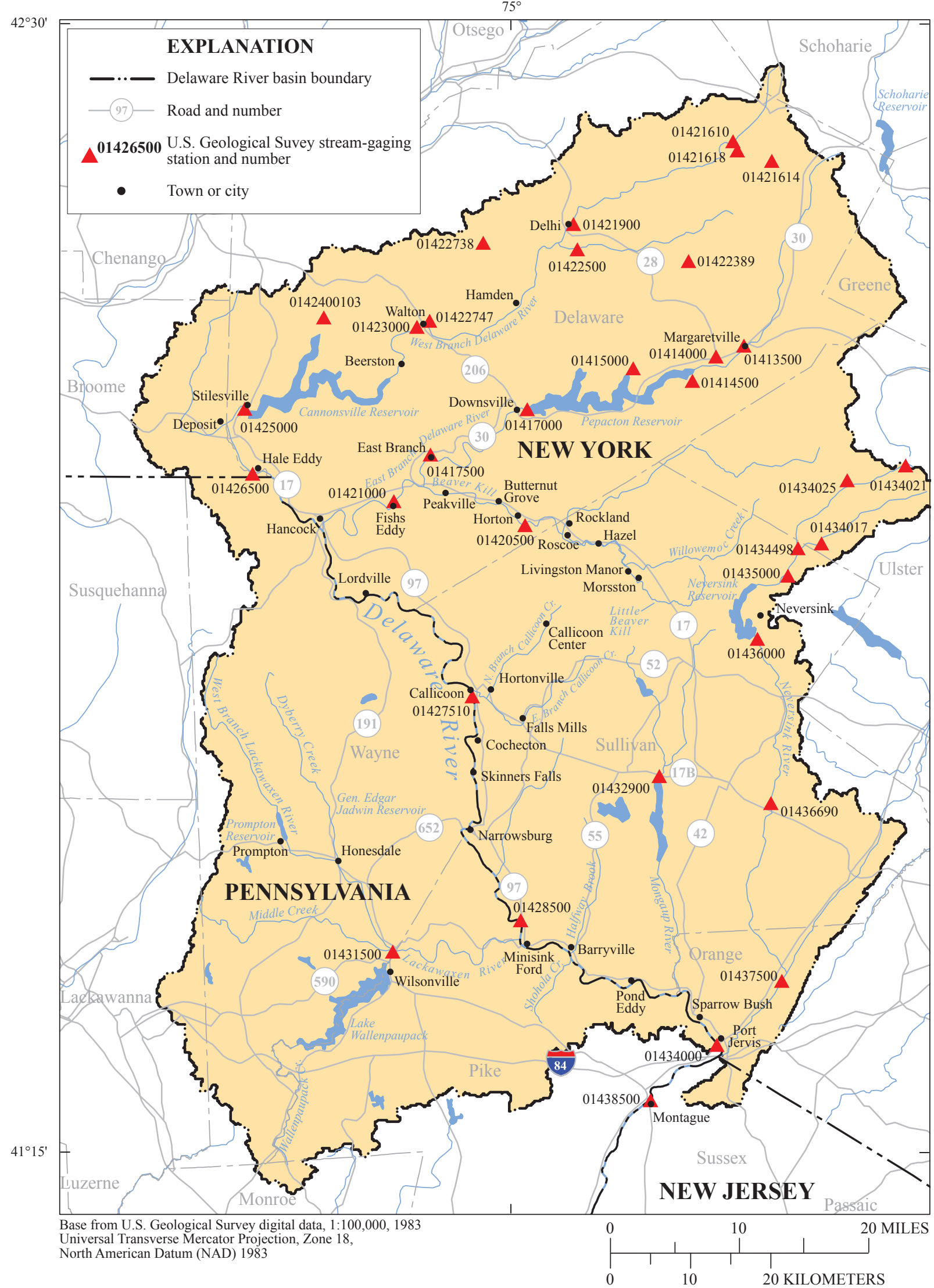

Figure 4B. Locations of selected U.S. Geological Survey stream-gaging stations in the Delaware River basin, NY, and surrounding area. (Station names and flood-related data listed in table 3.) 


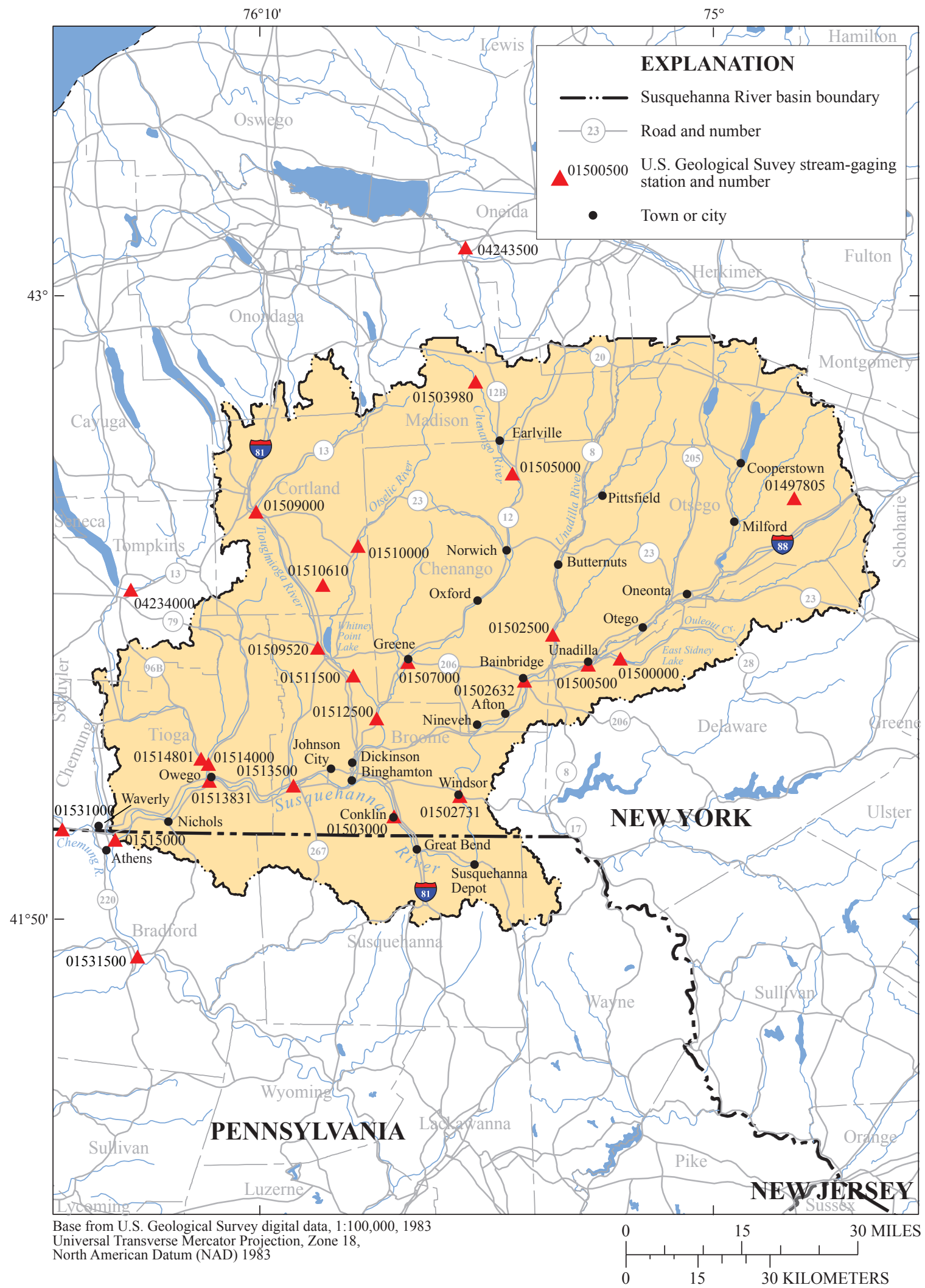

Figure 4C. Locations of selected U.S. Geological Survey stream-gaging stations in the Susquehanna River basin, NY, and surrounding area. (Station names and flood-related data listed in table 3.) 


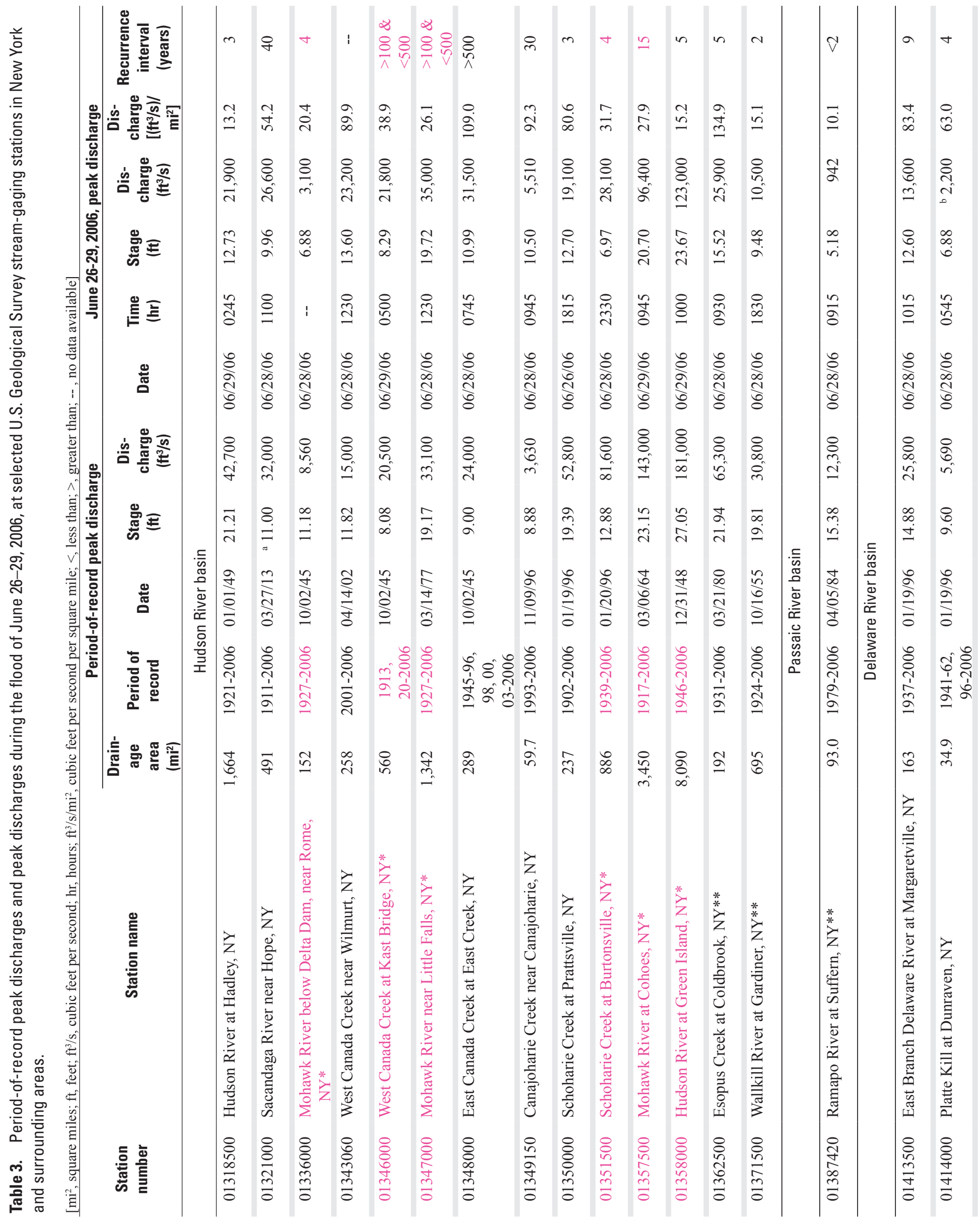




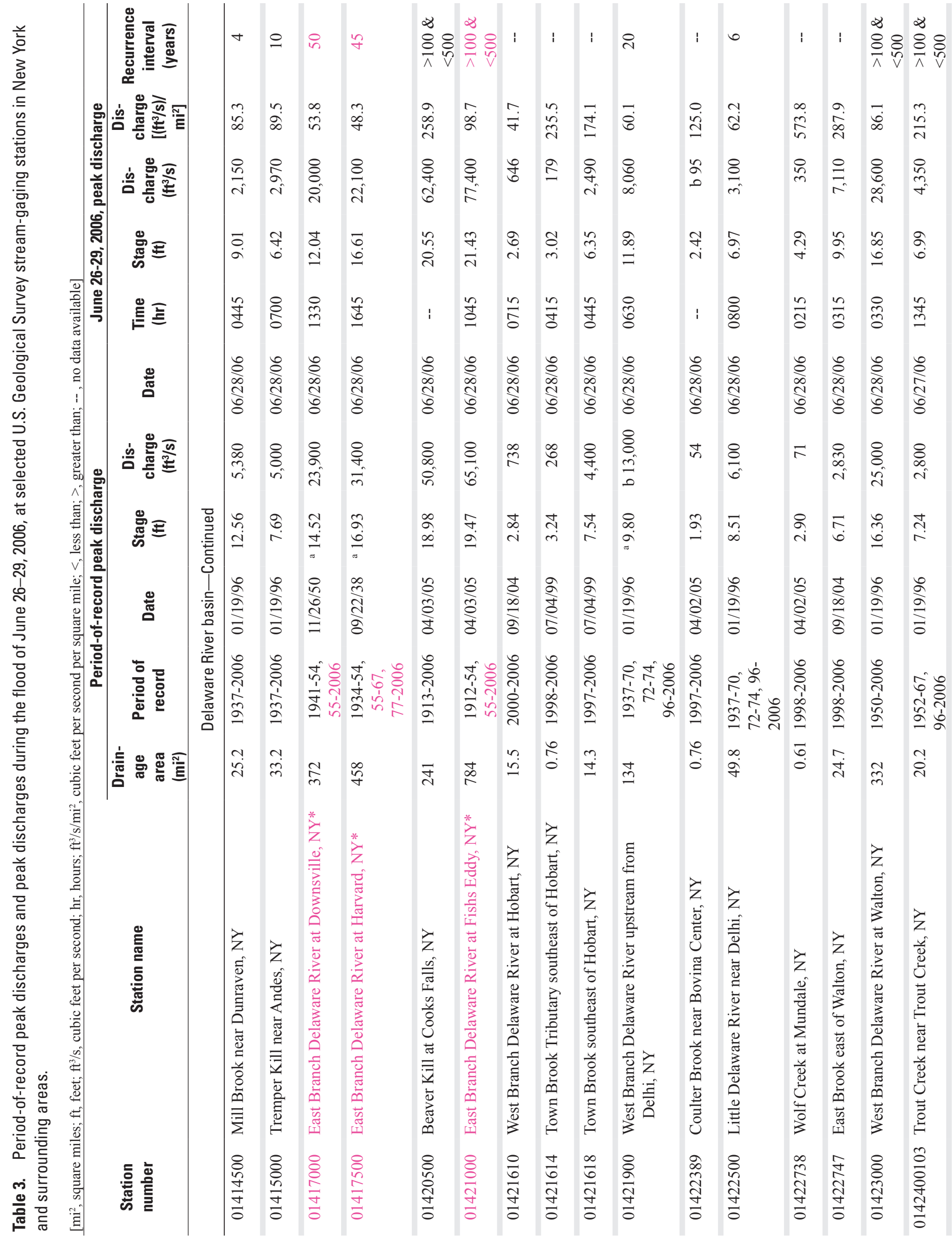




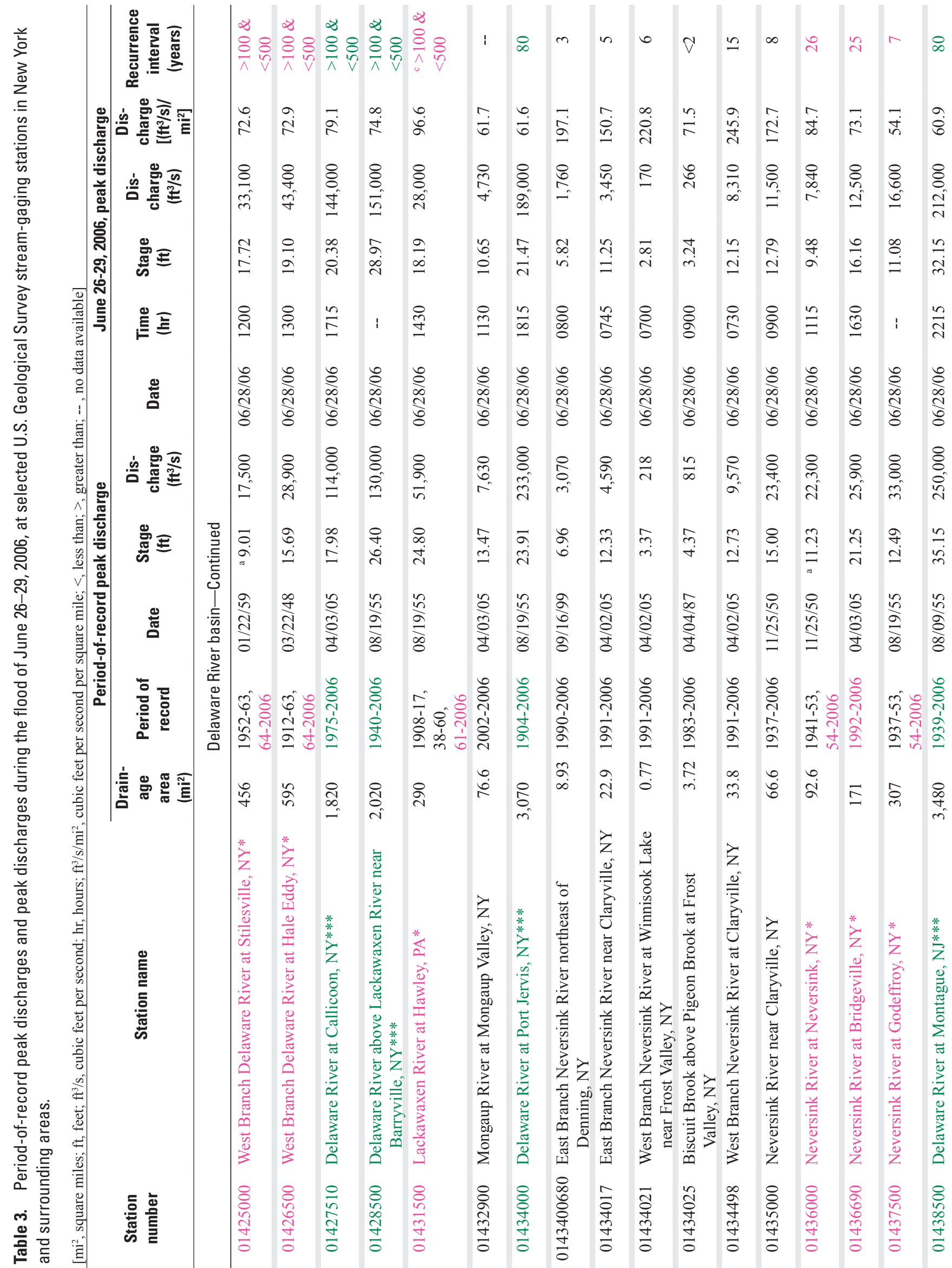




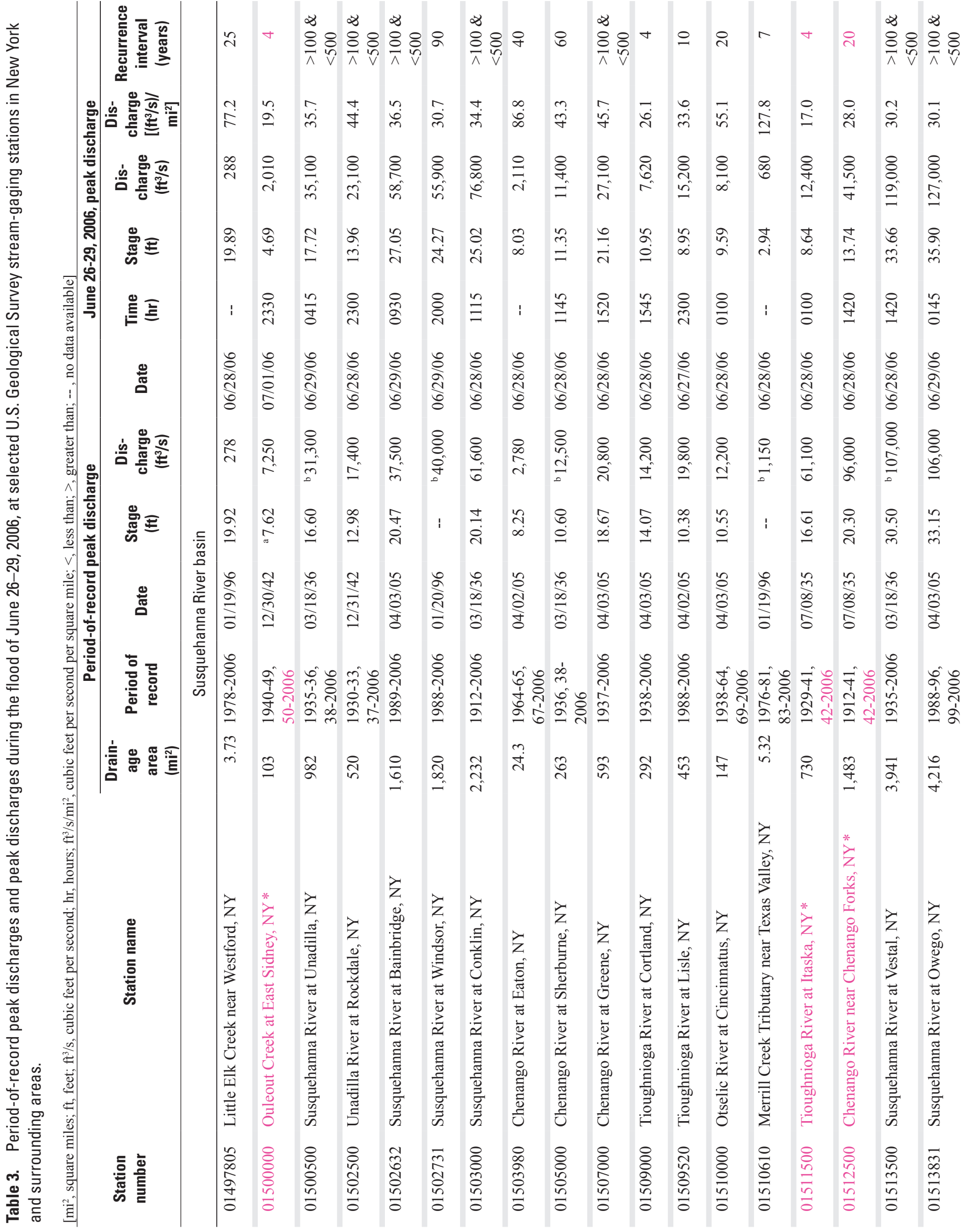




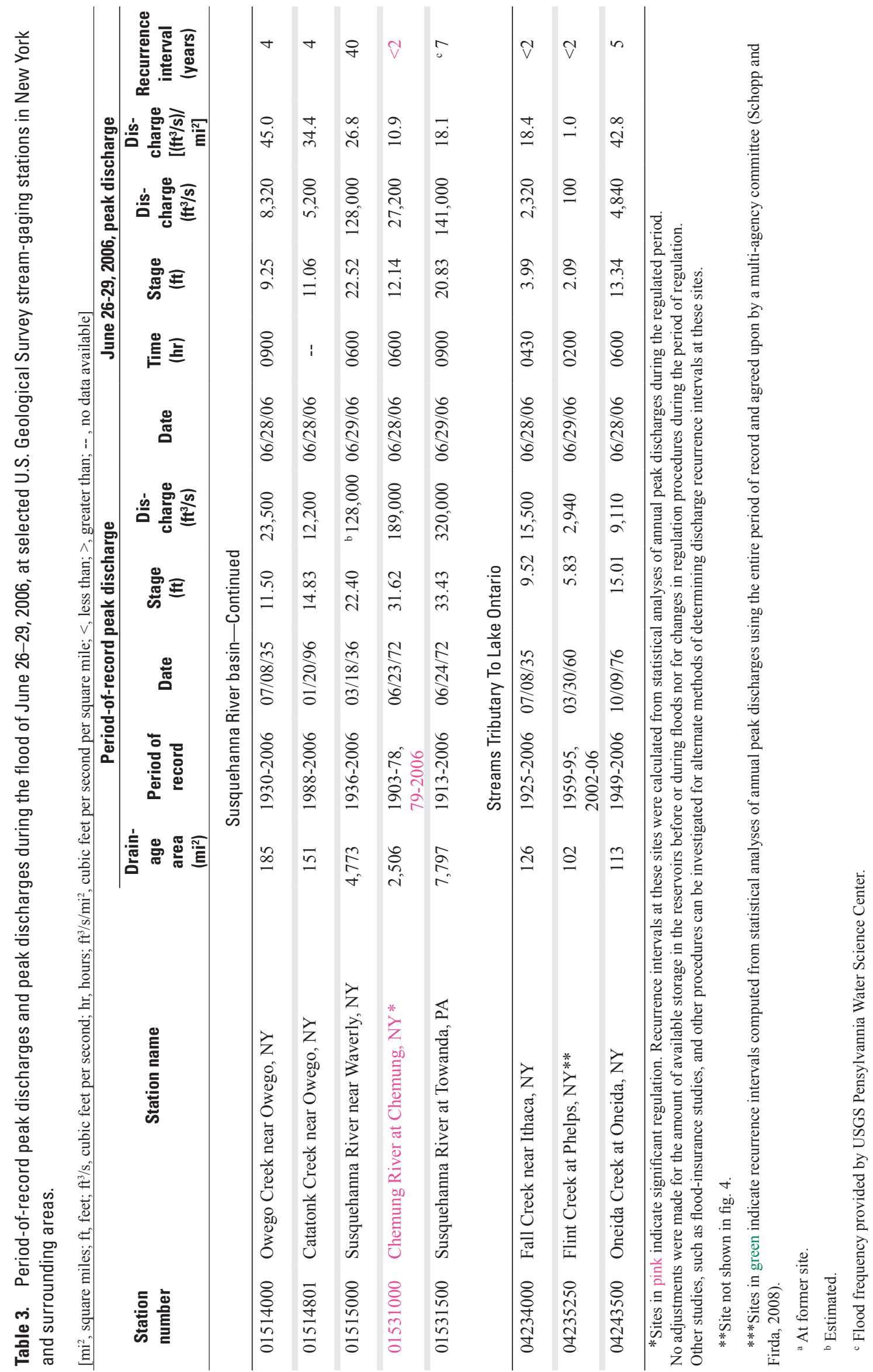




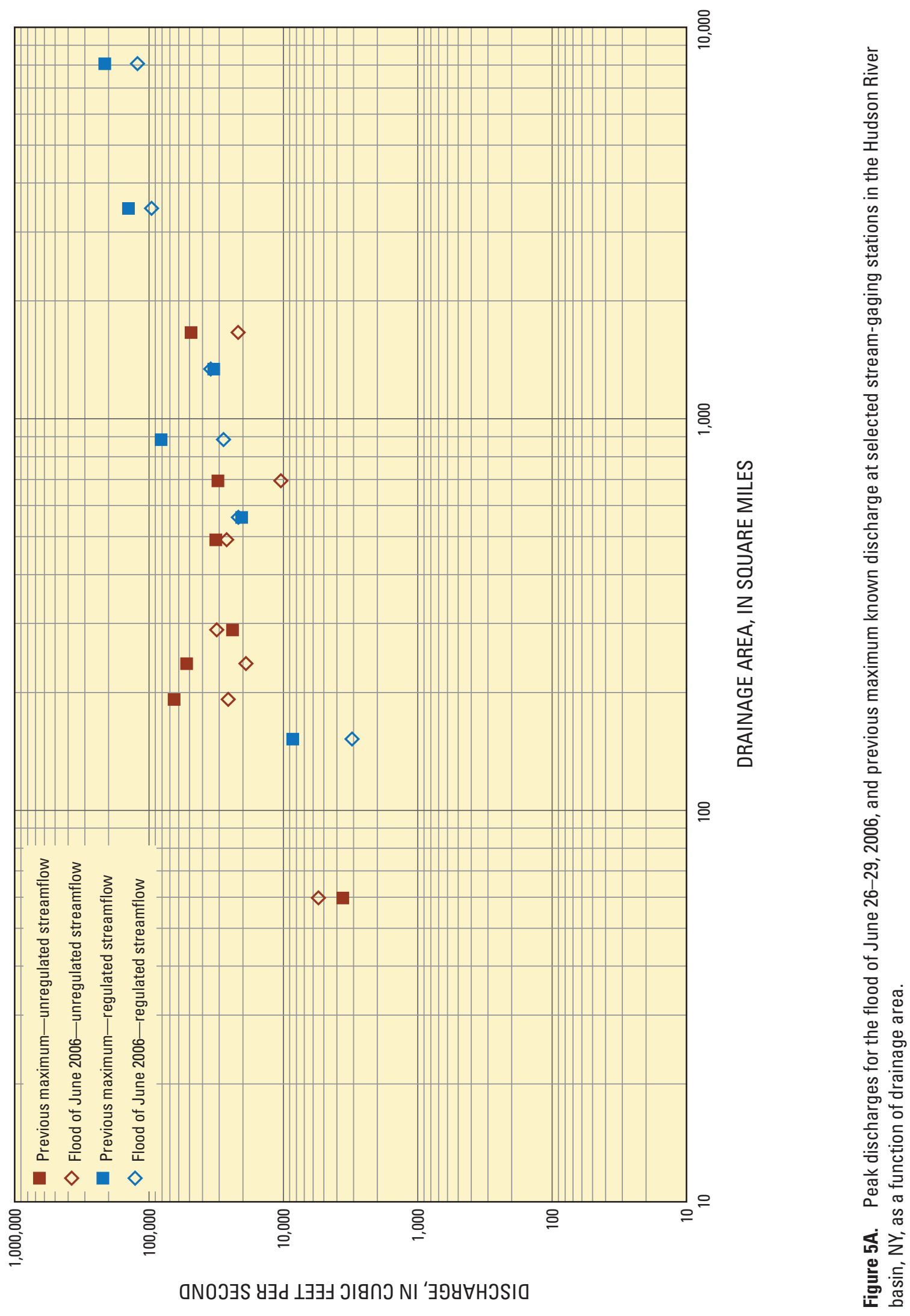



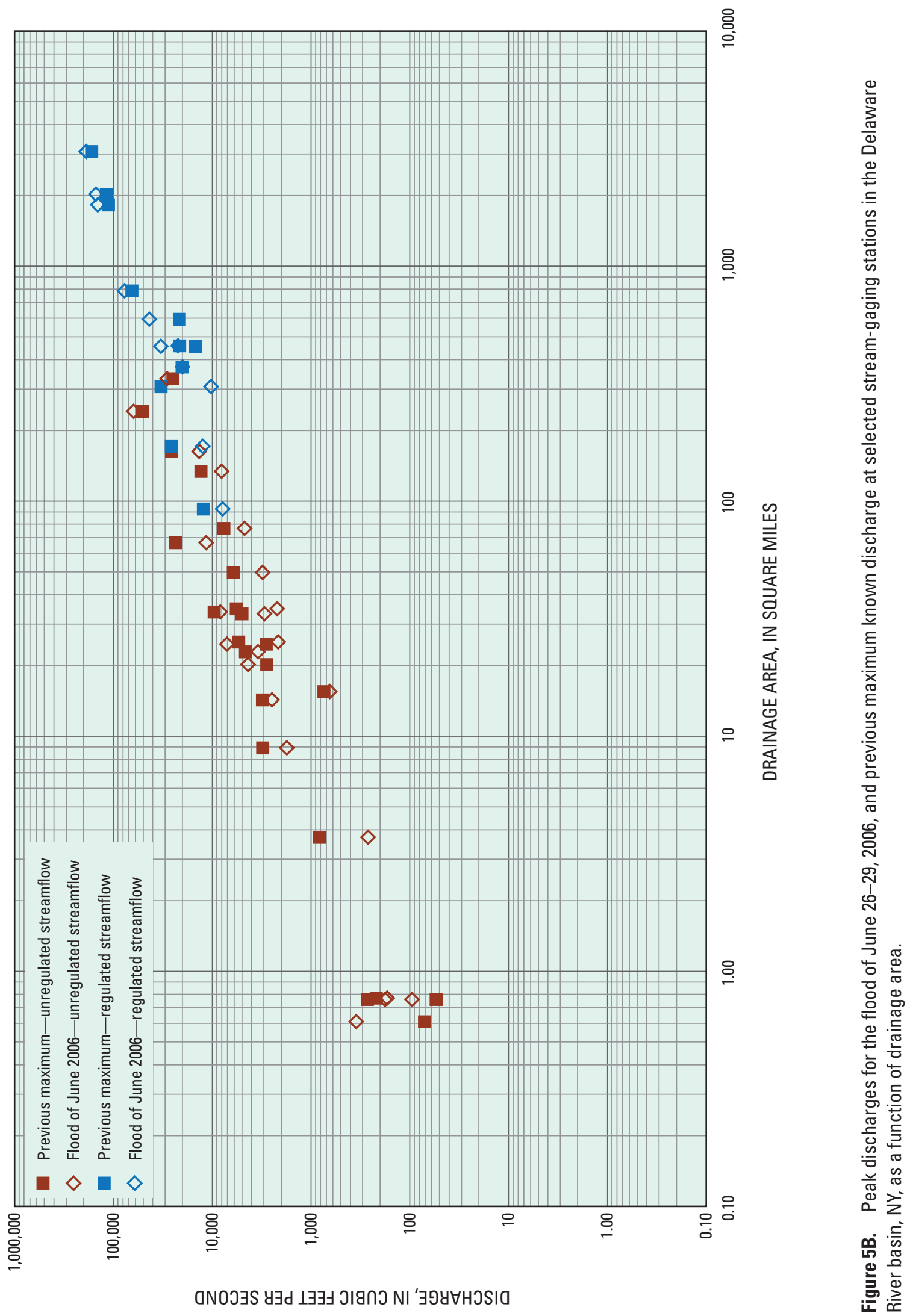


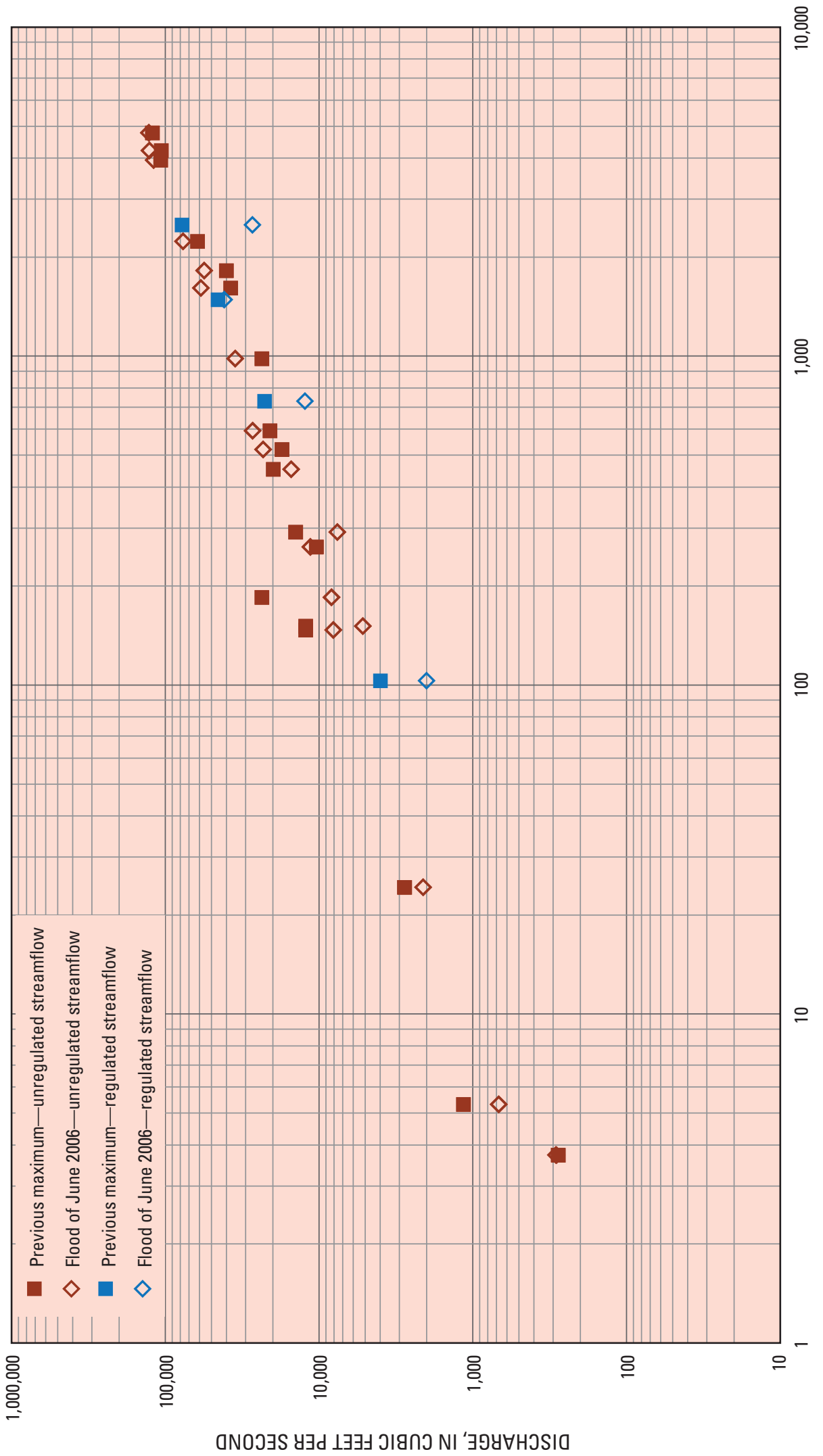

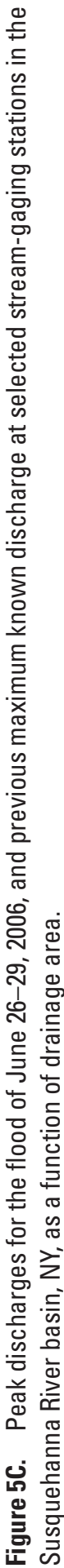




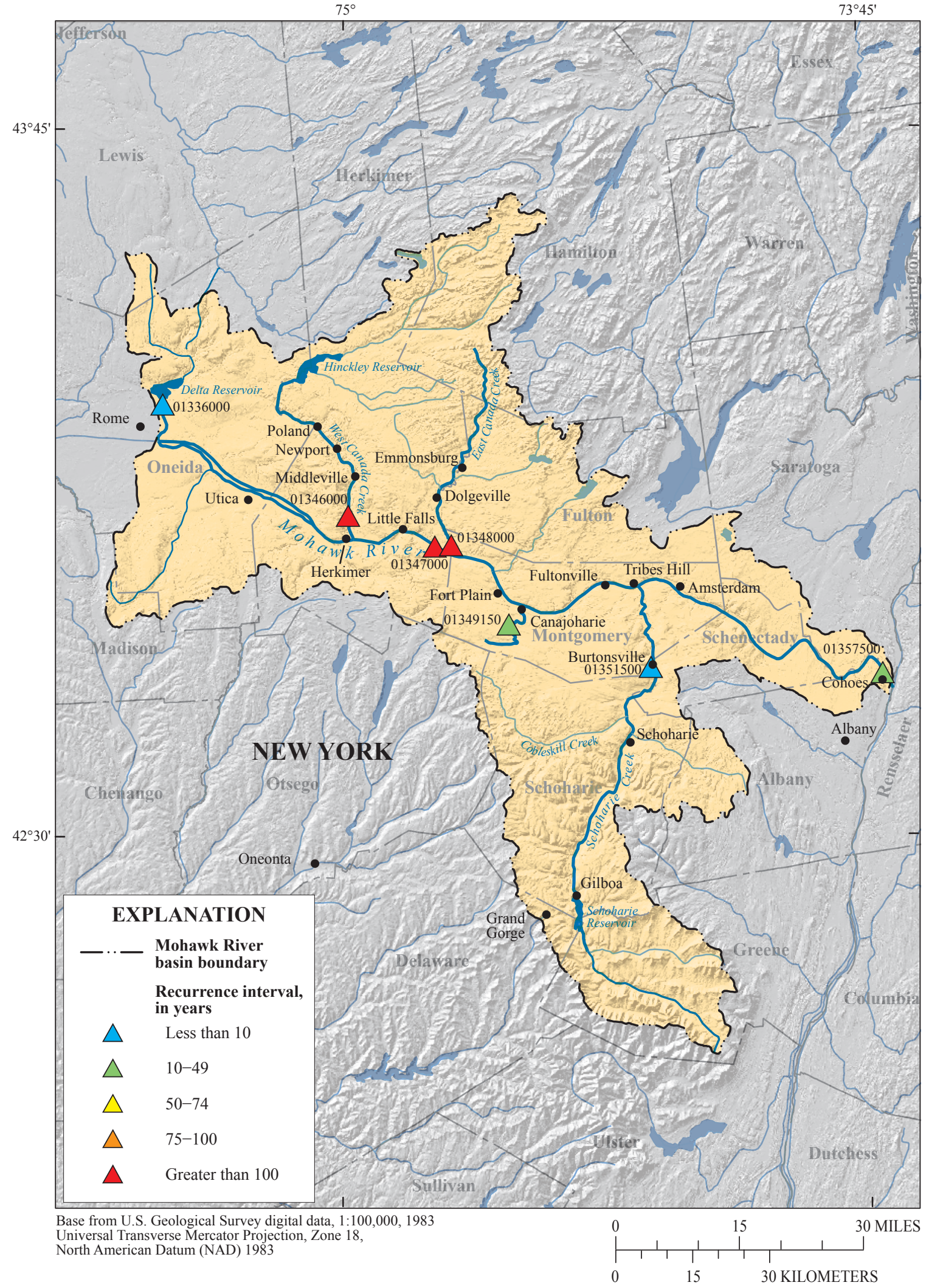

Figure 6A. Peak discharge recurrence intervals at selected U.S. Geological Survey stream-gaging stations in the Mohawk River basin, NY, for the flood of June 26-29, 2006. (Data are shown in table 3.) 


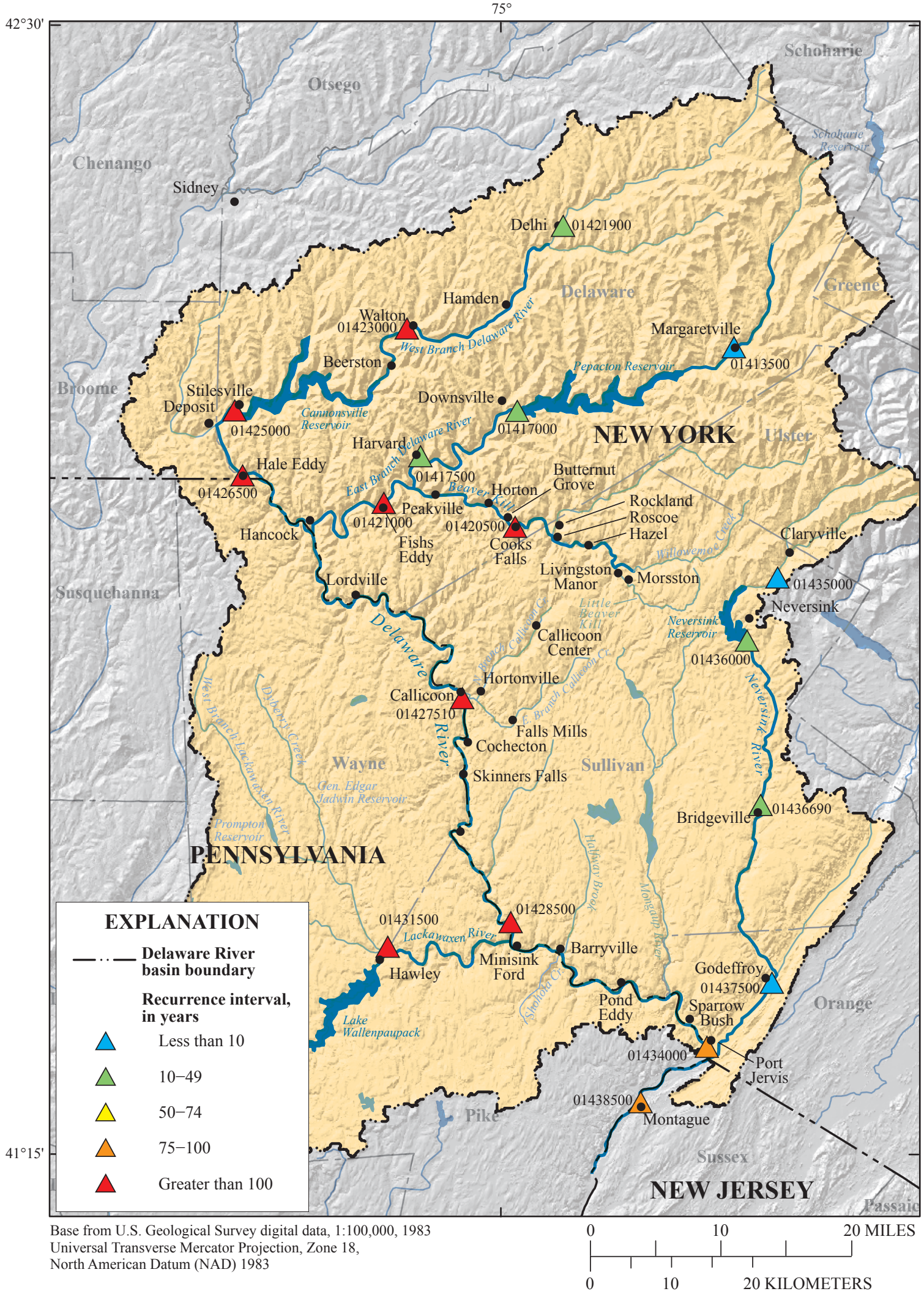

Figure 6B. Peak discharge recurrence intervals at selected U.S. Geological Survey stream-gaging stations in the Delaware River basin, NY, for the flood of June 26-29, 2006. (Data are shown in table 3.) 


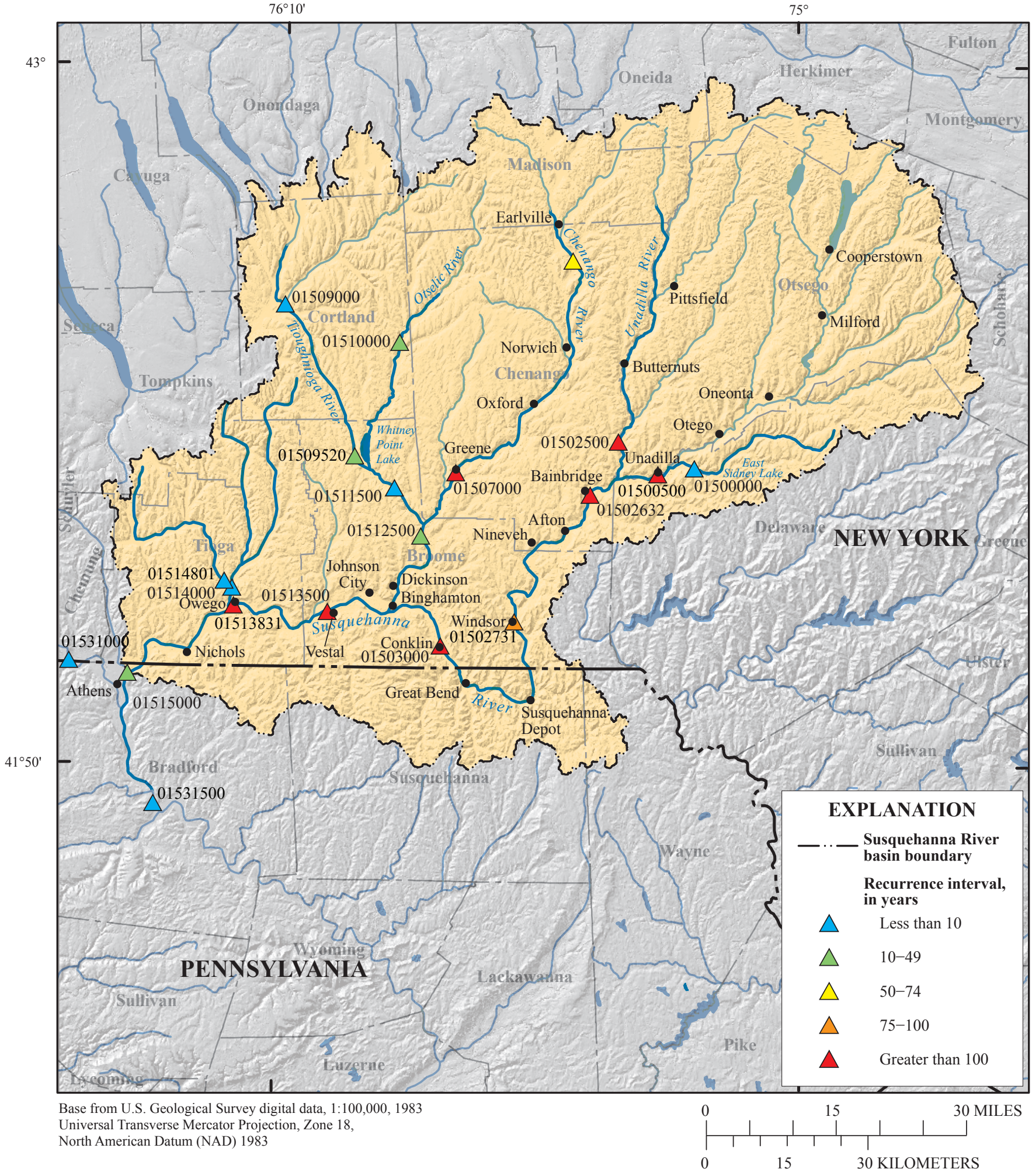

Figure 6C. Peak discharge recurrence intervals at selected U.S. Geological Survey stream-gaging stations in the Susquehanna River basin, NY, for the flood of June 26-29, 2006. (Data are shown in table 3.) 

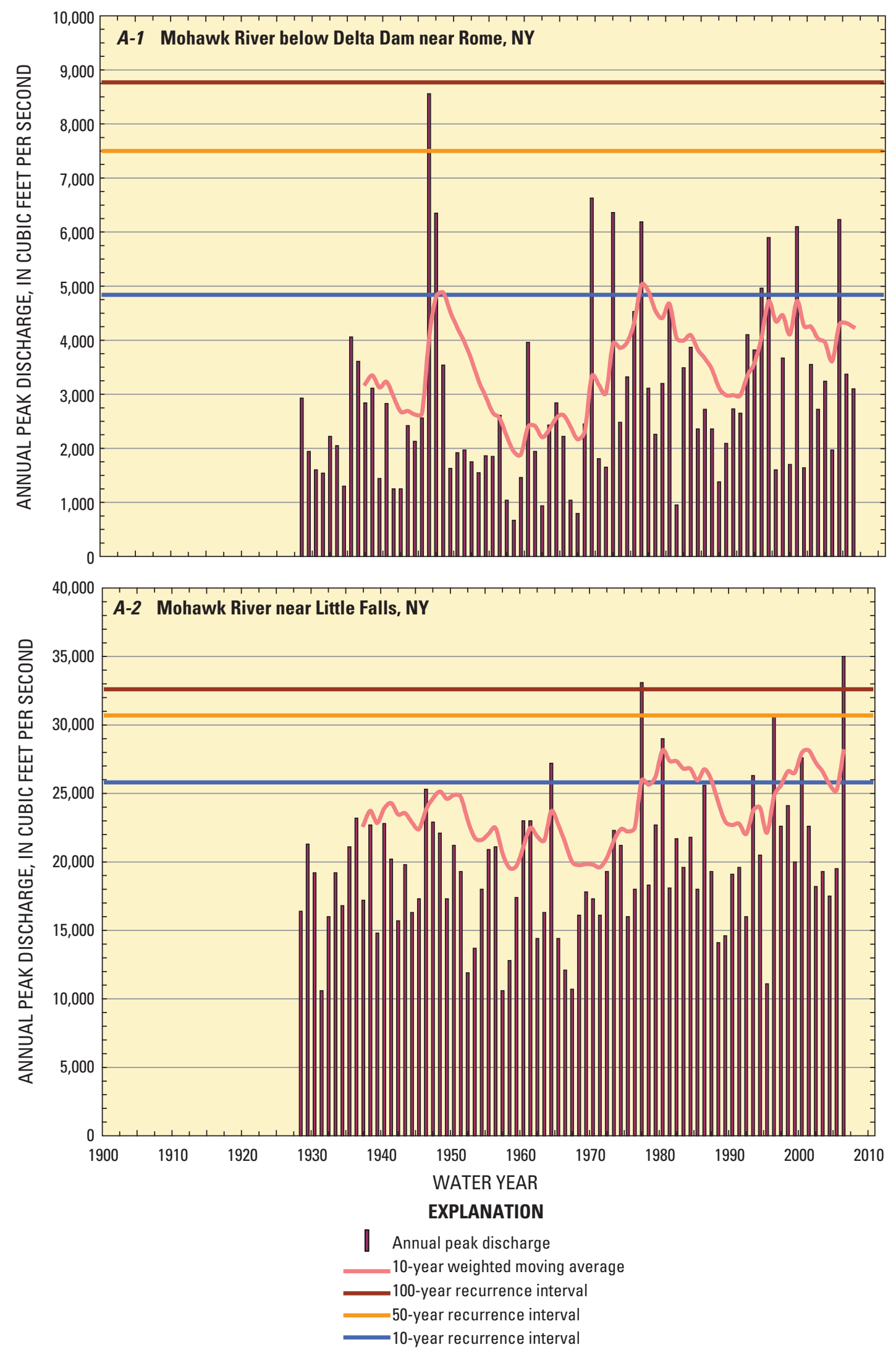

Figure 7A. $(A-1, A-2)$ Annual peak discharges through 2006, and discharges of the 10-, 50-, and 100year recurrence intervals for selected stations in the Mohawk River basin, NY. 

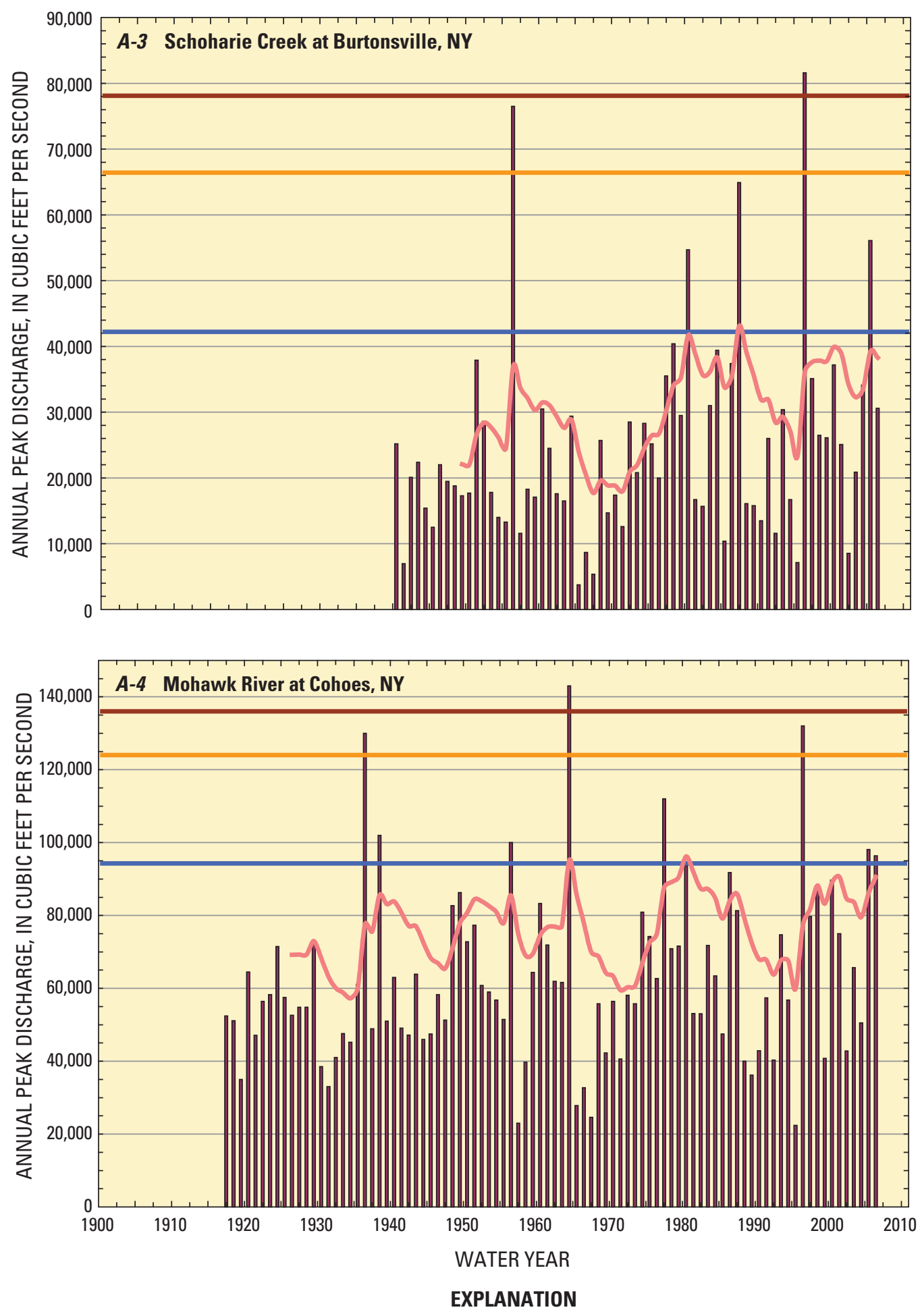

【 Annual peak discharge

10-year weighted moving average

100-year recurrence interval

50 -year recurrence interval

10-year recurrence interval

Figure 7A. $(A-3, A-4)$ Annual peak discharges through 2006, and discharges of the 10-, 50-, and 100year recurrence intervals for selected stations in the Mohawk River basin, NY. 
The USGS stream-gaging stations along the Mohawk River from below Delta Dam to Cohoes are regulated by power-generation dams, municipal water suppliers, and the New York State Canal Corporation. Recurrence intervals at these USGS stream-gaging stations ranged from less than 5 years to greater than 100 years. The USGS streamgaging station Mohawk River below Delta Dam near Rome recorded a peak discharge of $3,100 \mathrm{ft}^{3} / \mathrm{s}$ on June 28 which had a recurrence interval of less than 5 years (fig. 6A). Recurrence intervals at USGS stream-gaging stations on the major tributaries to the Mohawk River along the East and West Canada Creeks and the Schoharie Creek ranged from greater than 500 years at East Canada Creek at East Creek (01348000), to greater than 100 years at the West Canada Creek at Kast Bridge (01346000), to as low as less than 5 years at Schoharie Creek at Burtonsville (01351500). A major increase in the magnitude and frequency of the flooding along the Mohawk River downstream from the Mohawk River below Delta Dam near Rome stream-gaging station can be attributed to greater than 100-year inflows from the West and East Canada Creeks. The USGS stream-gaging station West Canada Creek at Kast Bridge, which has been in operation since 1920, recorded a new period-of-record maximum of $21,800 \mathrm{ft}^{3} / \mathrm{s}$. The East Canada Creek at East Creek stream-gaging station, in operation since 1945, also recorded a new period-of-record maximum of $31,500 \mathrm{ft}^{3} / \mathrm{s}$. The USGS stream-gaging station Schoharie Creek at Burtonsville recorded a peak discharge of $28,100 \mathrm{ft}^{3} / \mathrm{s}$ on June 28 , but the period-of-record maximum of $81,600 \mathrm{ft}^{3} / \mathrm{s}$ was recorded on January 20, 1996 (fig. 7A-3). The lack of major inflow from Schoharie Creek allowed for the natural attenuation of the peak discharge and a recurrence interval of only 15 years downstream at the Mohawk River at Cohoes stream-gaging station. The USGS stream-gaging station Mohawk River at Cohoes recorded a peak discharge of $96,400 \mathrm{ft}^{3} / \mathrm{s}$ on June 29 (fig. 7A-4). The USGS stream-gaging station Hudson River at Green Island (01358000), located downstream from the confluence with the Mohawk River, recorded a peak discharge of $123,000 \mathrm{ft}^{3} / \mathrm{s}$ on June 29 , which has a recurrence interval of only 5 years. Antecedent conditions, precipitation and runoff patterns, and basin characteristics all play a role in determining the peak water-surface elevation and discharge at a stream-gaging station. Discharge hydrographs for selected USGS stream-gaging stations in the Mohawk River Basin for the period June 25-30, 2006, are shown in figure 8 .

\section{Delaware River Basin}

All USGS stream-gaging stations along the East and West Branches of the Delaware River and along the main stem of the Delaware River down to Port Jervis recorded peak discharges on June 28. The peak discharge recorded at the stream-gaging station East Branch Delaware River at Margaretville (01413500), upstream from the Pepacton Reservoir, was $13,600 \mathrm{ft}^{3} / \mathrm{s}$. The peak discharges recorded at the stream-gaging stations West Branch Delaware River upstream from Delhi (01421900) and West Branch Delaware River at Walton (01423000), upstream from the Cannonsville Reservoir, were 8,060 $\mathrm{ft}^{3} / \mathrm{s}$ and $28,600 \mathrm{ft}^{3} / \mathrm{s}$, respectively (fig. 8B-3). The flood frequency of the peak discharge at East Branch Delaware River at Margaretville was estimated to have a 9-year recurrence interval (table 3). The flood frequency along the West Branch of the Delaware River, upstream from Cannonsville Reservoir, was much greater than that recorded along the East Branch upstream from Pepacton Reservoir (fig. 6B). The peak discharge at the West Branch Delaware River upstream from Delhi had an estimated recurrence interval of 20 years, and the peak discharge at West Branch Delaware River at Walton had an estimated recurrence interval of greater than 100 years (fig. 7B-6). Recurrence intervals were generally 25 years or less for peak discharges along several gaged tributaries to the East Branch of the Delaware River upstream from the Pepacton Reservoir. Flood frequency could not be computed at gaged tributaries upstream from Cannonsville Reservoir because of the short periods of record.

The peak discharges at USGS stream-gaging stations downstream from Pepacton and Cannonsville Reservoirs, along the East and West Branches of the Delaware River, equaled or exceeded the previous period-of-record maximums set during the 2004 and 2005 floods. The USGS streamgaging station East Branch Delaware River at Downsville (01417000), immediately downstream from the Pepacton Reservoir, recorded a peak discharge of $20,000 \mathrm{ft}^{3} / \mathrm{s}$ on June 28 (fig. 8B-2). The estimated recurrence interval computed for this peak is 50 years. The period-of-record maximum for this station since the Pepacton Reservoir began storage operations in September 1954 is $20,200 \mathrm{ft}^{3} / \mathrm{s}$, recorded on September 18, 2004 (fig.7B-2). The peak discharge at the USGS streamgaging station East Branch Delaware River at Harvard (01417500), 22,100 ft $3 / \mathrm{s}$, has a recurrence interval of 45 years (figs. 7B-3, 8B-2). Farther downstream along the East Branch of the Delaware River, the peak discharge at the USGS stream-gaging station at Fishs Eddy (01421000), 77,400 ft $3 / \mathrm{s}$, had a recurrence interval of greater than 100 years and as of 2006 is a new period-of-record maximum (figs. 7B-5, 8B-2). The increase in flood magnitude and frequency at this station compared to those for the Downsville and Harvard streamgaging stations is a result of the significant inflow from the Beaver Kill. The Beaver Kill at Cooks Falls stream-gaging station (01420500) also recorded a new period-of-record maximum of $62,400 \mathrm{ft}^{3} / \mathrm{s}$ on June 28 , which had a recurrence interval greater than 100 years (figs. 6B, 7B-4).

The USGS stream-gaging station West Branch Delaware River at Stilesville (01425000) recorded a new periodof-record maximum discharge, since the current degree of regulation began in 1963, of $33,100 \mathrm{ft}^{3} / \mathrm{s}$ on June 28 (figs. 7B-7, 8B-4). The recurrence interval for this peak was estimated to be greater than 100 years (fig. 6B). The June 28, 2006, peak discharge is also the maximum recorded discharge at this station since the station was put into operation in July 1952. The West Branch Delaware River 

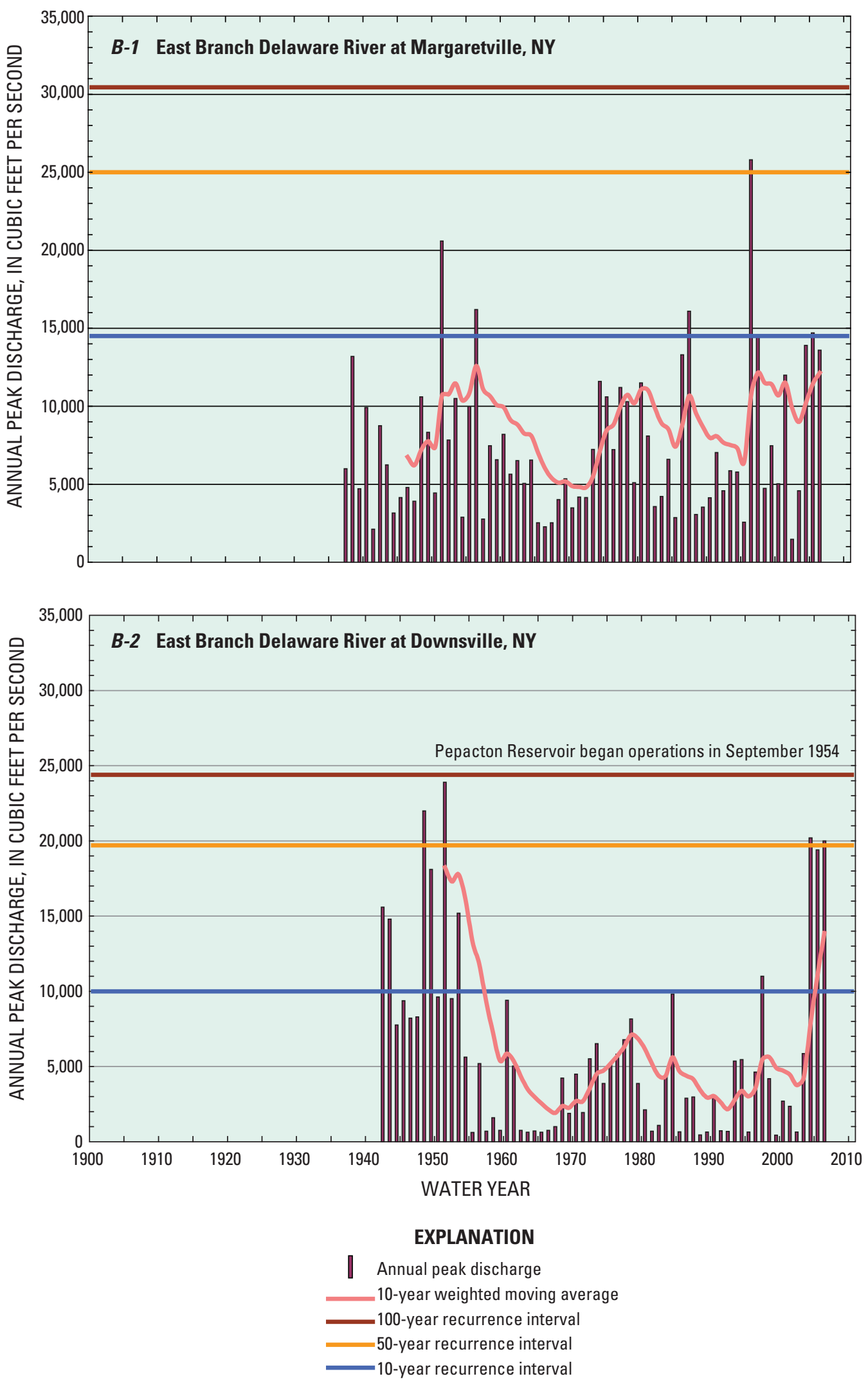

Figure 7B. (B-1, B-2) Annual peak discharges through 2006, and discharges of the 10-, 50-, and 100 -year recurrence intervals for selected stations in the Delaware River basin, NY. 

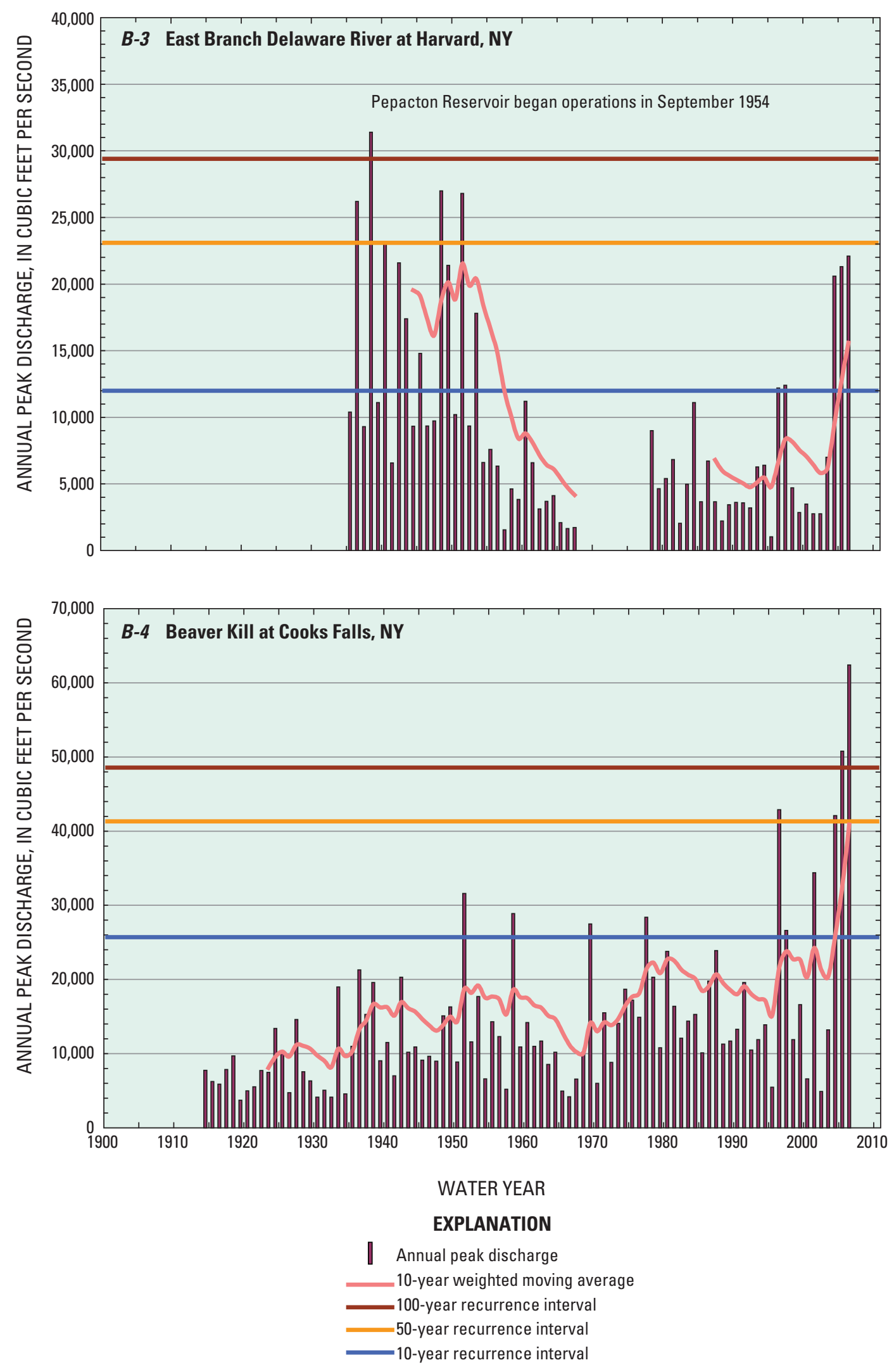

Figure 7B. (B-3, B-4) Annual peak discharges through 2006, and discharges of the 10-, 50-, and 100 -year recurrence intervals for selected stations in the Delaware River basin, NY 

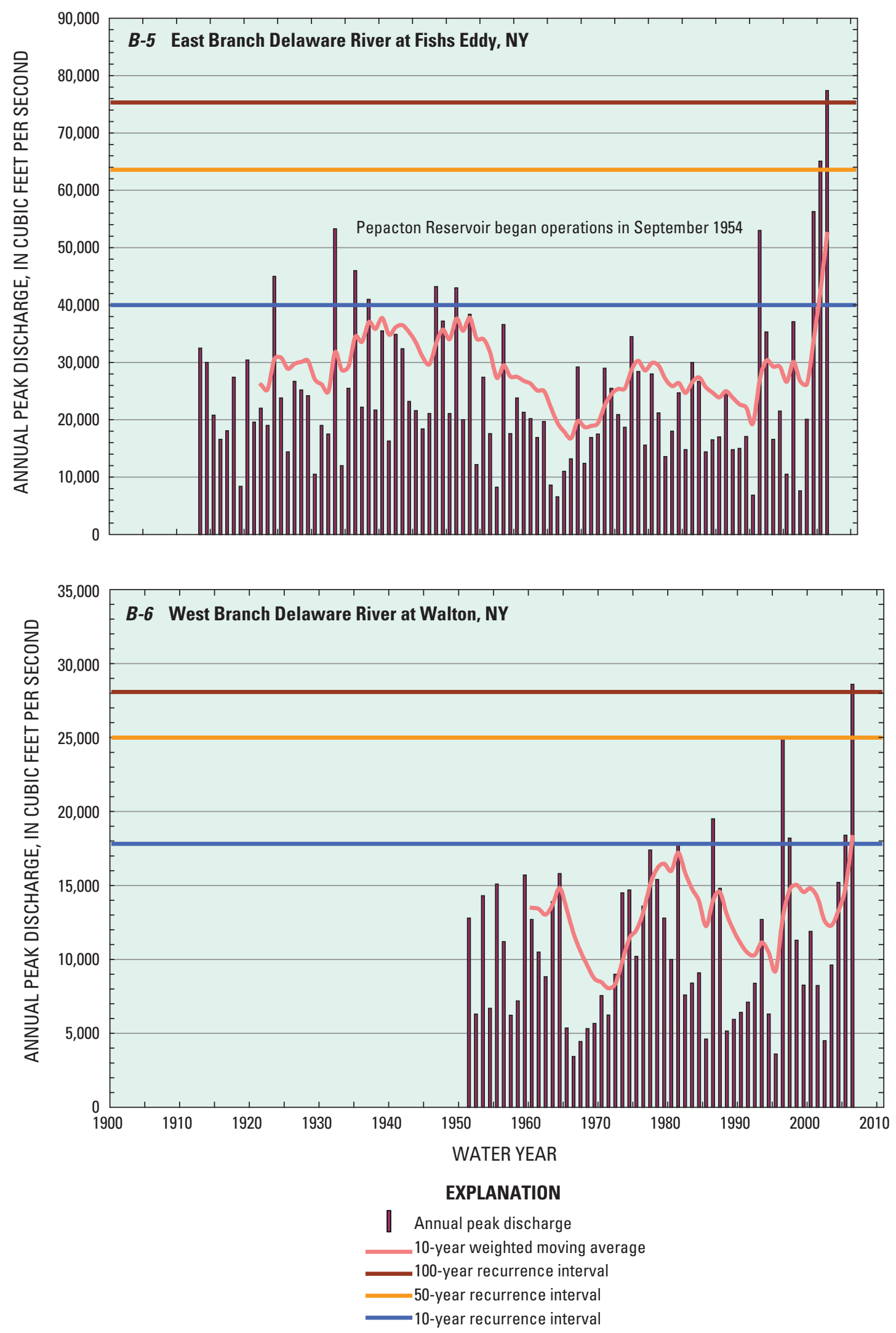

Figure 7B. $\quad(B-5, B-6)$ Annual peak discharges through 2006, and discharges of the 10-, 50-, and 100 -year recurrence intervals for selected stations in the Delaware River basin, NY. 
at Hale Eddy stream-gaging station (01426500) recorded a new period-of-record maximum of $43,400 \mathrm{ft}^{3} / \mathrm{s}$ on June 28 (figs. 7B-8, 8B-4). This peak discharge has an estimated recurrence interval of greater than 100 years and is the maximum discharge at this station since at least 1903.

Along the main stem of the Delaware River downstream from the confluence of the East and West Branches near Hancock to Port Jervis, peak discharges were recorded at three USGS stream-gaging stations. The Delaware River at Callicoon stream-gaging station (01427510), which has been in operation since 1975, recorded a new period-of-record maximum of $144,000 \mathrm{ft}^{3} / \mathrm{s}$ on June 28 (figs. 7B-9, 8B-5). The USGS stream-gaging station Delaware River above Lackawaxen River near Barryville (01428500) also recorded a new period-of-record maximum of $151,000 \mathrm{ft}^{3} / \mathrm{s}$ on June 28 (figs. 7B-10, 8B-5). The peak discharges at Callicoon and Barryville have an estimated recurrence interval of greater than 100 years. The Delaware River at Port Jervis is the most downstream USGS stream-gaging station along the main stem of the Delaware River in New York. The peak discharge at the Delaware River at Port Jervis stream-gaging station (01434000) was $189,000 \mathrm{ft}^{3} / \mathrm{s}$, recorded on June 28 (figs. 7B-11, 8B-5). This peak is a new period-of-record maximum, since regulation began in 1963, and ranks as the third highest peak since 1903 (fig. 7B-11). The recurrence interval for this peak discharge was calculated to be 80 years. The maximum peak discharge at this station was recorded on August 19, 1955, and unlike the June 2006 flood, the 1955 flood peak was magnified by major inflows from the Lackawaxen and Mongaup Rivers. Discharge hydrographs for selected USGS stream-gaging stations in the Delaware River basin for the period of June 25-30, 2006, are shown in figure 8 .

\section{Susquehanna River Basin}

Several USGS stream-gaging stations along the Susquehanna River recorded new period-of-record maximums as a result of the June 2006 flood. The Susquehanna River at Unadilla stream-gaging station (01500500), which has been in operation since 1938, recorded a new period-of-record maximum of $35,100 \mathrm{ft}^{3} / \mathrm{s}$ on June 29 with a recurrence interval of greater than 100 years (figs. $6 \mathrm{C}, 7 \mathrm{C}-1,8 \mathrm{C}-1$ ). The peak exceeded the estimated peak discharge for the March 18, 1936, flood at this site. The Unadilla River is a major tributary to the Susquehanna River and enters downstream from the Susquehanna River at Unadilla stream-gaging station. The recurrence interval for the peak discharge of $23,100 \mathrm{ft}^{3} / \mathrm{s}$ on June 28 at the Unadilla River at Rockdale stream-gaging station (01502500) was estimated to be greater than 100 years and is a new period-of-record maximum (figs. 7C-2, 8C-1).

The USGS stream-gaging stations Susquehanna River at Bainbridge (01502632), Susquehanna River at Windsor (01502731), and Susquehanna River at Conklin (01503000) each recorded a new period-of-record maximum on June 28 or
29. The Susquehanna River at Conklin stream-gaging station has been in operation since 1913, and its previous period-ofrecord maximum of $61,600 \mathrm{ft}^{3} / \mathrm{s}$ was set during the March 1936 flood. The peak discharge recorded at the Susquehanna River at Conklin stream-gaging station on June 28 was $76,800 \mathrm{ft}^{3} / \mathrm{s}$ (fig. 7C-3). Recurrence intervals for the June 2006 flood peak discharges at these three stations range from 90 to greater than 100 years.

Most USGS stream-gaging stations along the Susquehanna River from Conklin to Vestal and on the Chenango, Tioughnioga, and Otselic Rivers recorded peak discharges on June 28. It was assumed that rainfall patterns across the region generated increased runoff downstream from Bainbridge, which resulted in a steeper slope to the rising limb of the hydrographs for this area and subsequently earlier peak discharges at downstream stations. The discharges at the Susquehanna River at Unadilla and Bainbridge stream-gaging stations continued to rise at a steady rate until they peaked on June 29 (fig. 8C-1). Peak inflows to the Susquehanna River from the Chenango and Tioughnioga Rivers were not at record levels. The recurrence interval for the peak discharge at the Chenango River at Greene stream-gaging station (01507000), which was a new period-of-record maximum, was estimated to be greater than 100 years, but the recurrence interval downstream at the Chenango River at Chenango Forks (01512500) stream-gaging station was only 20 years (fig. 7C-7). The recurrence intervals for the peak discharges at the USGS stream-gaging stations along the Tioughnioga River at Lisle (01509520) and Itaska (01511500) were less than 20 years (fig. 6C). Flood peaks in this area along other major tributaries, including the Owego and Chemung Rivers, were less than a 5-year recurrence interval. Although discharges on the major tributaries were below record levels downstream from the confluence of the Susquehanna and Unadilla Rivers, they were sufficient to maintain record levels along the Susquehanna River from Unadilla downstream to Waverly. The USGS stream-gaging station Susquehanna River at Vestal (01513500) recorded a peak discharge of $119,000 \mathrm{ft}^{3} / \mathrm{s}$ on June 28 , which has a recurrence interval of greater than 100 years; the peak discharge exceeded both the period-of-record maximum and the estimated peak discharge of 107,000 ft $3 / \mathrm{s}$ for the March 18, 1936, flood at this site (fig. 7C-8). The floods of March 1936 and June 1972 were devastating along the Susquehanna River near and downstream from Waverly. The USGS stream-gaging station Susquehanna River near Waverly, NY, (01515000) has been in continuous operation since February 1937. The period-ofrecord maximum for the Susquehanna River near Waverly stream-gaging station was $121,000 \mathrm{ft}^{3} / \mathrm{s}$ recorded on June 23, 1972 (fig. 7C-10). The March 18, 1936, peak discharge was estimated to be $128,000 \mathrm{ft}^{3} / \mathrm{s}$. The June 29,2006 , peak discharge was $128,000 \mathrm{ft}^{3} / \mathrm{s}$ and was estimated to have a recurrence interval of 40 years (fig. 6C, 8C-2). The June 2006 flood ranks as the worst flood along the Susquehanna River for areas as far upstream as Unadilla and as far downstream as just upstream from Waverly since the early 1930s and possibly 

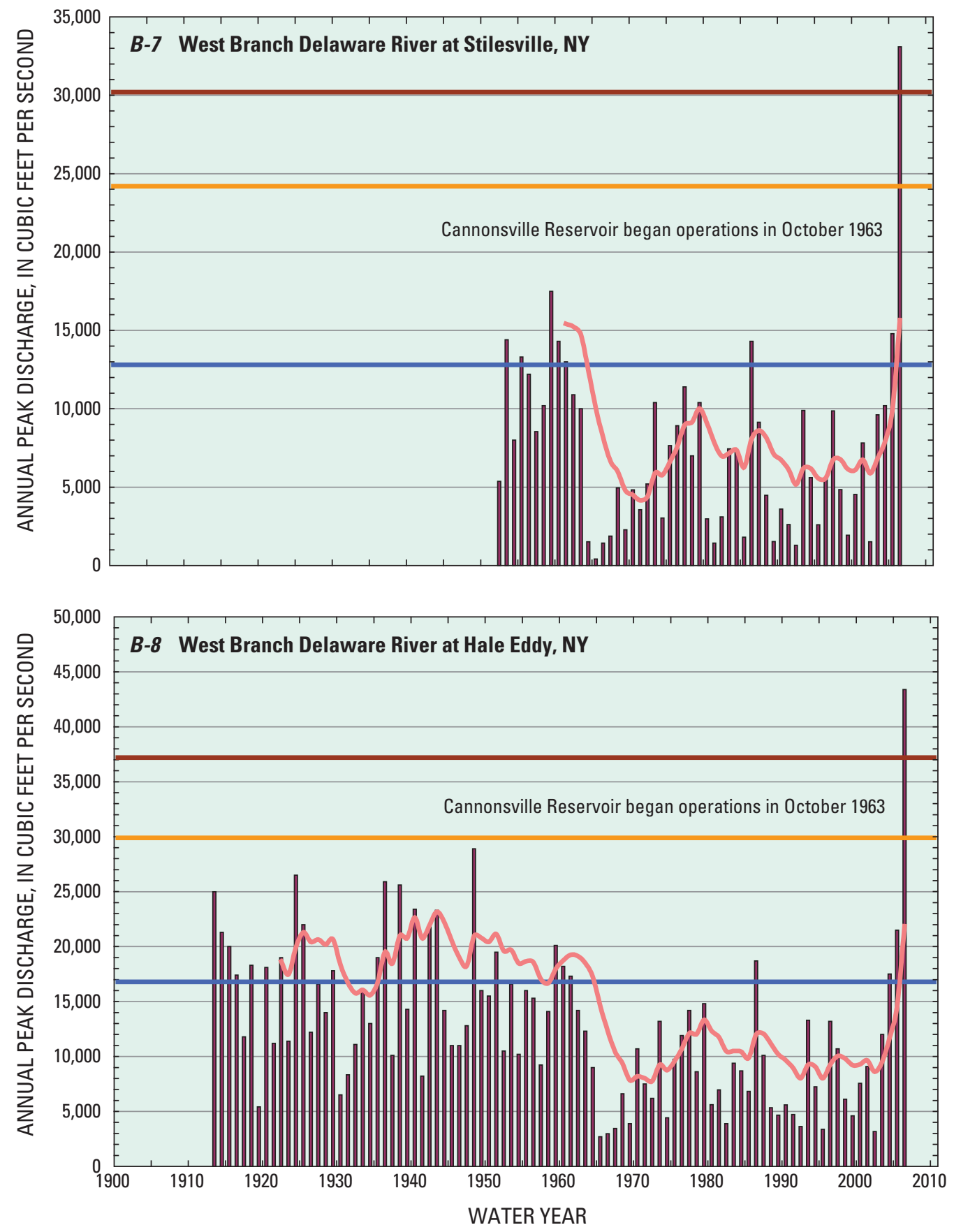

\section{EXPLANATION}

॥ Annual peak discharge 10-year weighted moving average

100 -year recurrence interval

50 -year recurrence interval

10-year recurrence interval

Figure 7B. (B-7, B-8) Annual peak discharges through 2006, and discharges of the 10-, 50-, and 100-year recurrence intervals for selected stations in the Delaware River basin, NY. 

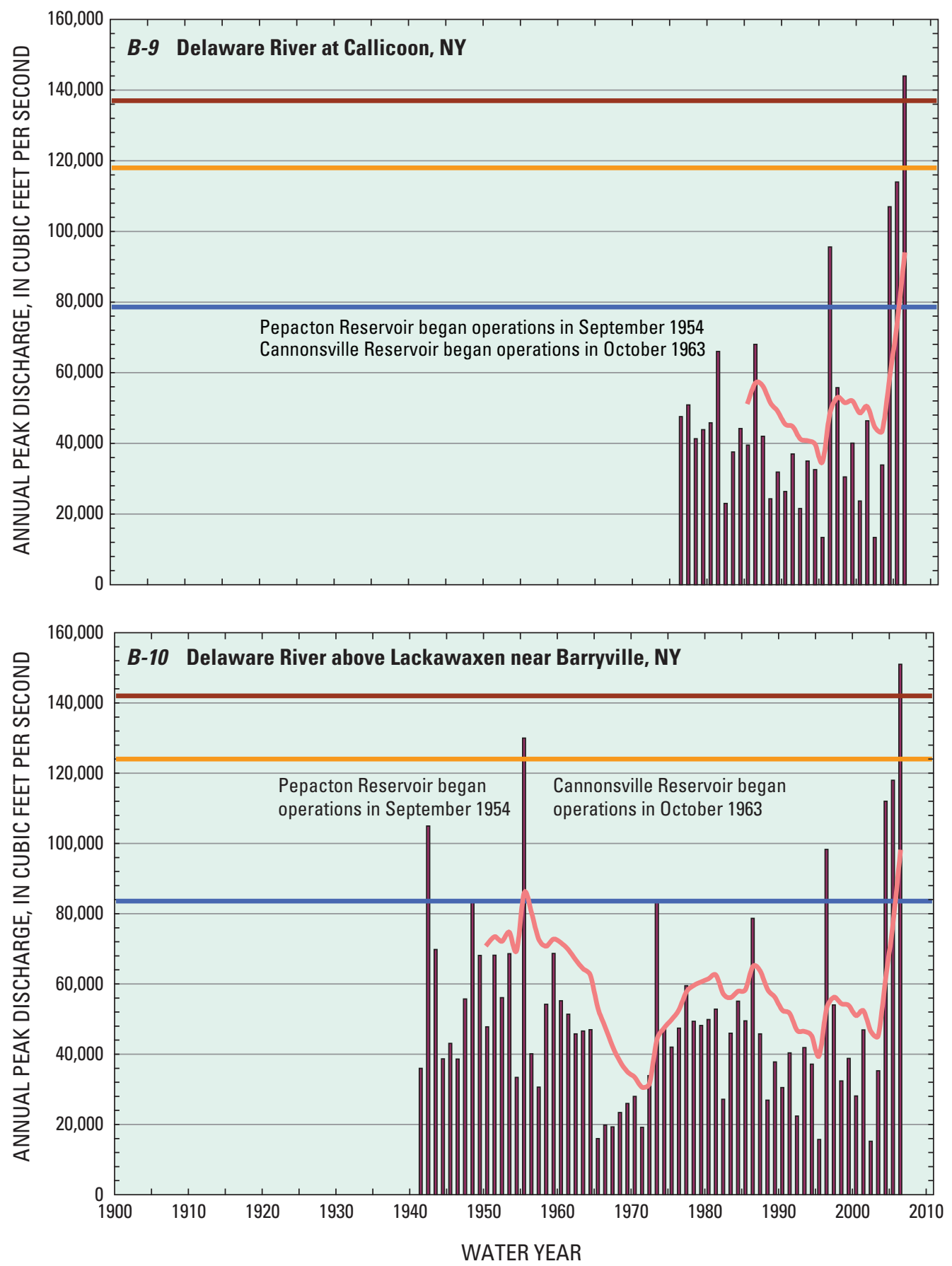

EXPLANATION

\Annual peak discharge 10-year weighted moving average 100-year recurrence interval 50-year recurrence interval 10 -year recurrence interval

Figure 7B. (B-9, B-10) Annual peak discharges through 2006, and discharges of the 10-, 50-, and 100 -year recurrence intervals for selected stations in the Delaware River basin, NY. 


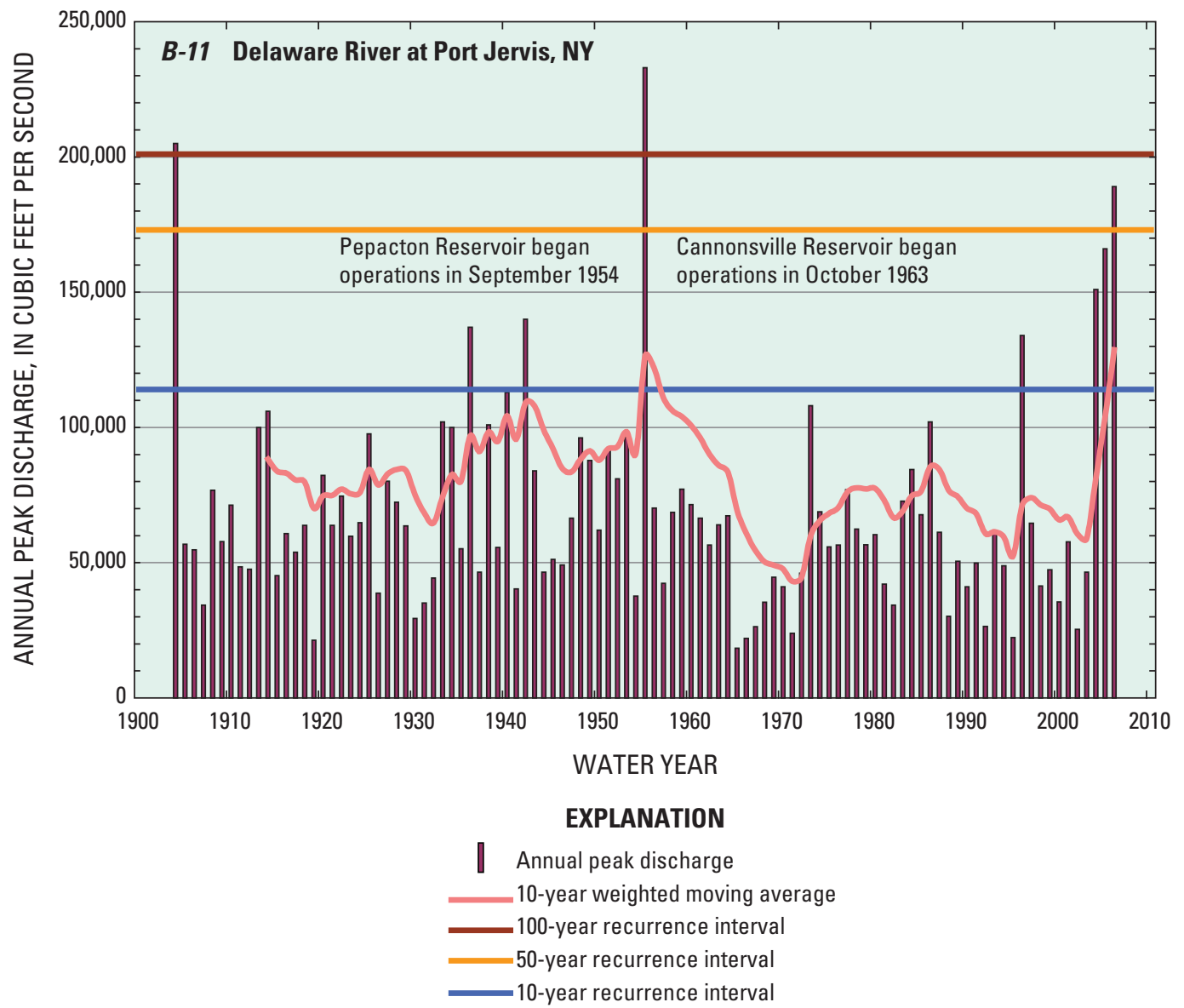

Figure 7B. (B-11) Annual peak discharges through 2006, and discharges of the 10-, 50-, and 100year recurrence intervals for selected stations in the Delaware River basin, NY. 

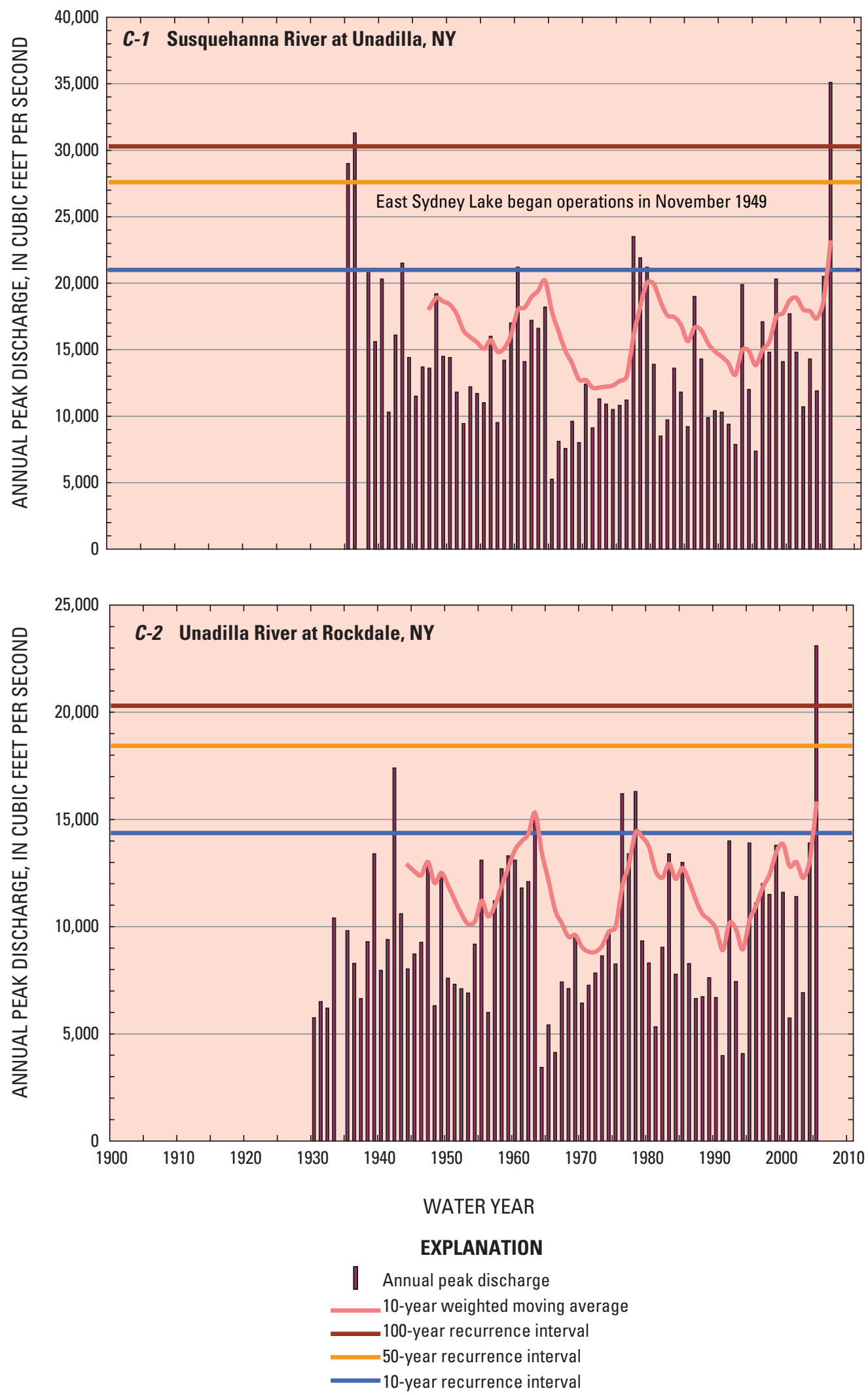

Figure 7C. (C-1, $C-2)$ Annual peak discharges through 2006, and discharges of the 10-, 50-, and 100-year recurrence intervals for selected stations in the Susquehanna River basin, NY. 

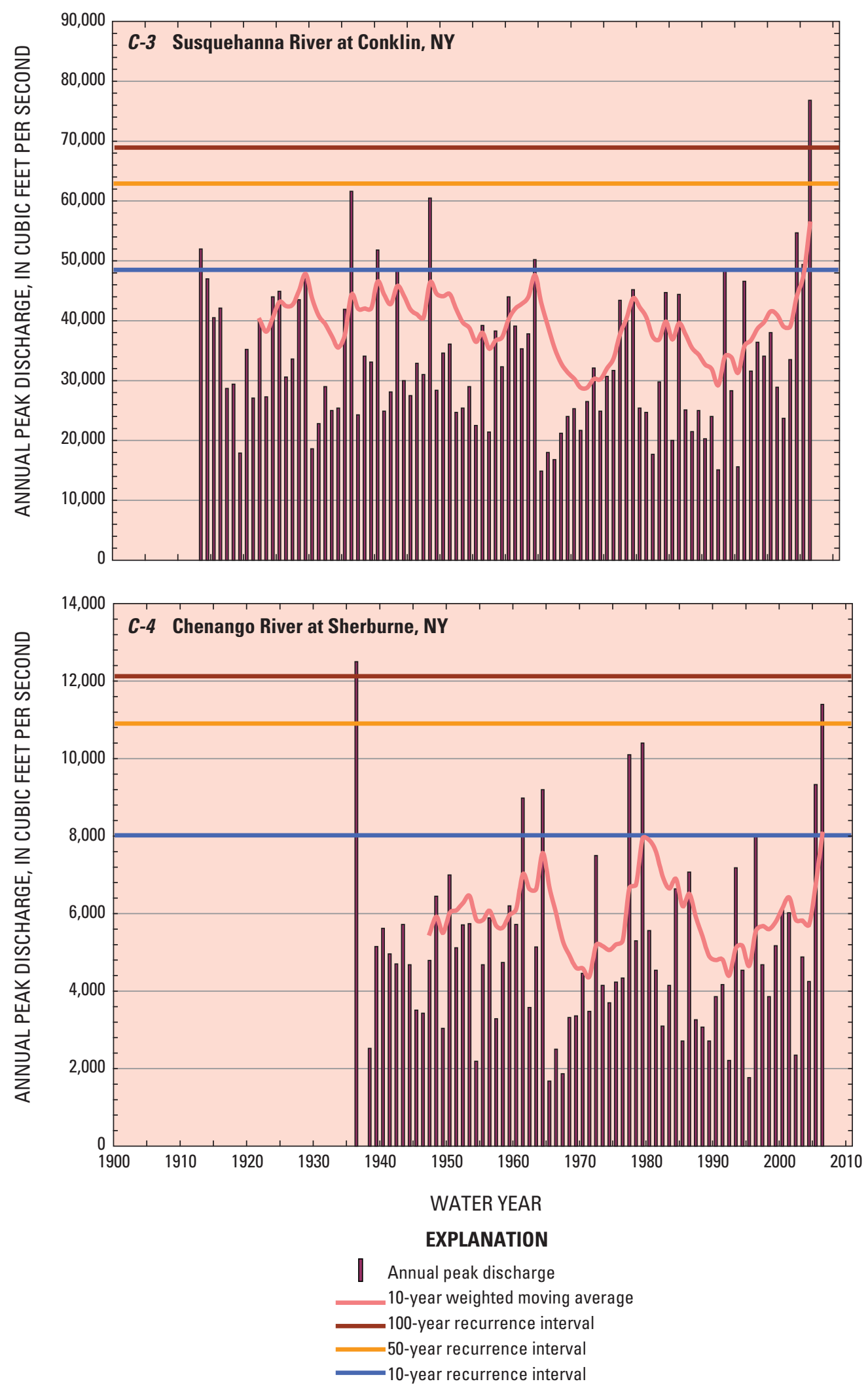

Figure 7C. (C-3, $C-4)$ Annual peak discharges through 2006, and discharges of the 10-, 50-, and 100year recurrence intervals for selected stations in the Susquehanna River basin, NY. 

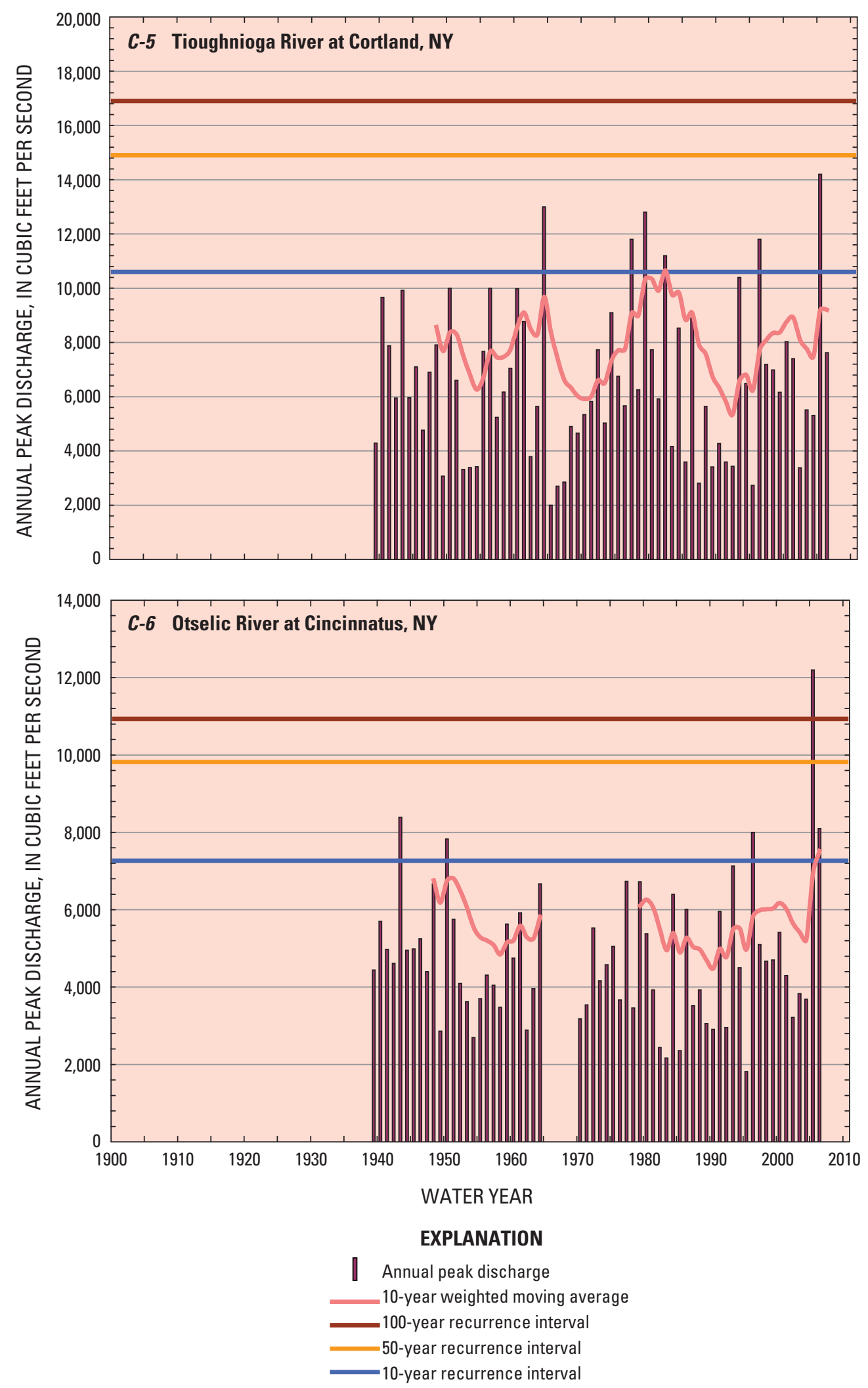

Figure 7C. (C-5, C-6) Annual peak discharges through 2006, and discharges of the 10-, 50-, and 100year recurrence intervals for selected stations in the Susquehanna River basin, NY. 

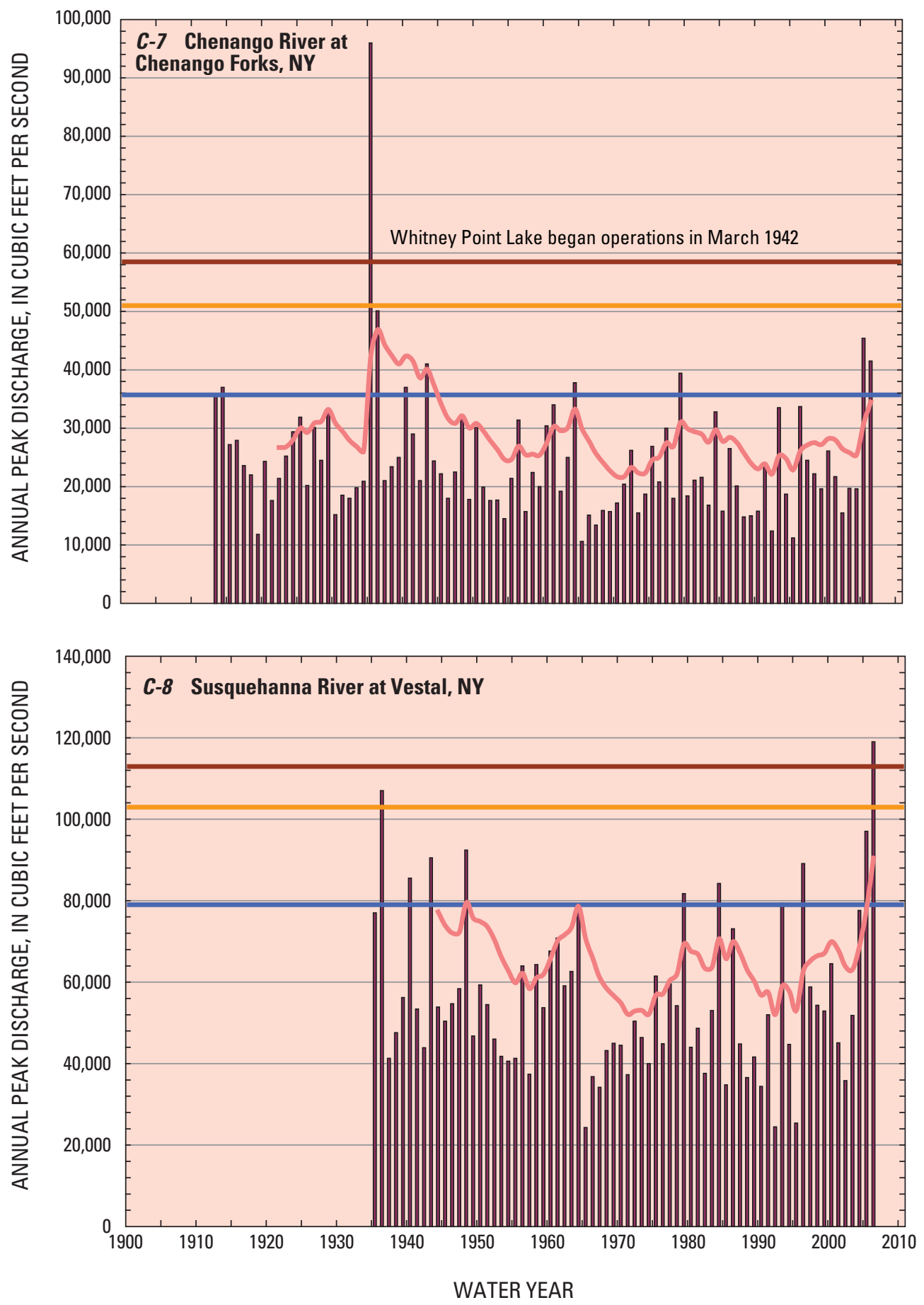

EXPLANATION

॥ Annual peak discharge 10-year weighted moving average 100-year recurrence interval 50 -year recurrence interval 10-year recurrence interval

Figure 7C. (C-7, C-8) Annual peak discharges through 2006, and discharges of the 10-, 50-, and 100year recurrence intervals for selected stations in the Susquehanna River basin, NY. 

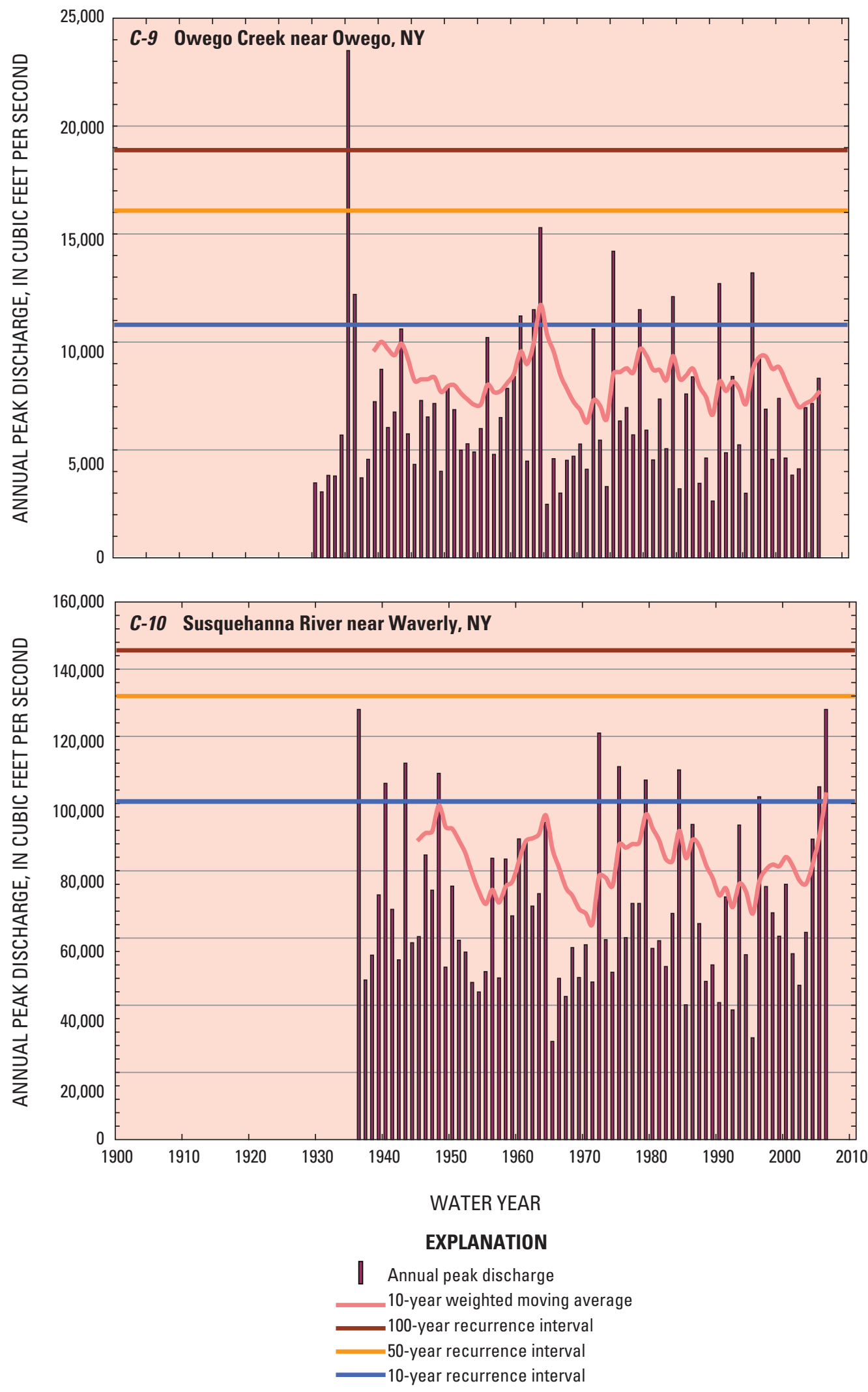

Figure 7C. (C-9, C-10) Annual peak discharges through 2006, and discharges of the 10-, 50-, and 100 -year recurrence intervals for selected stations in the Susquehanna River basin, NY. 

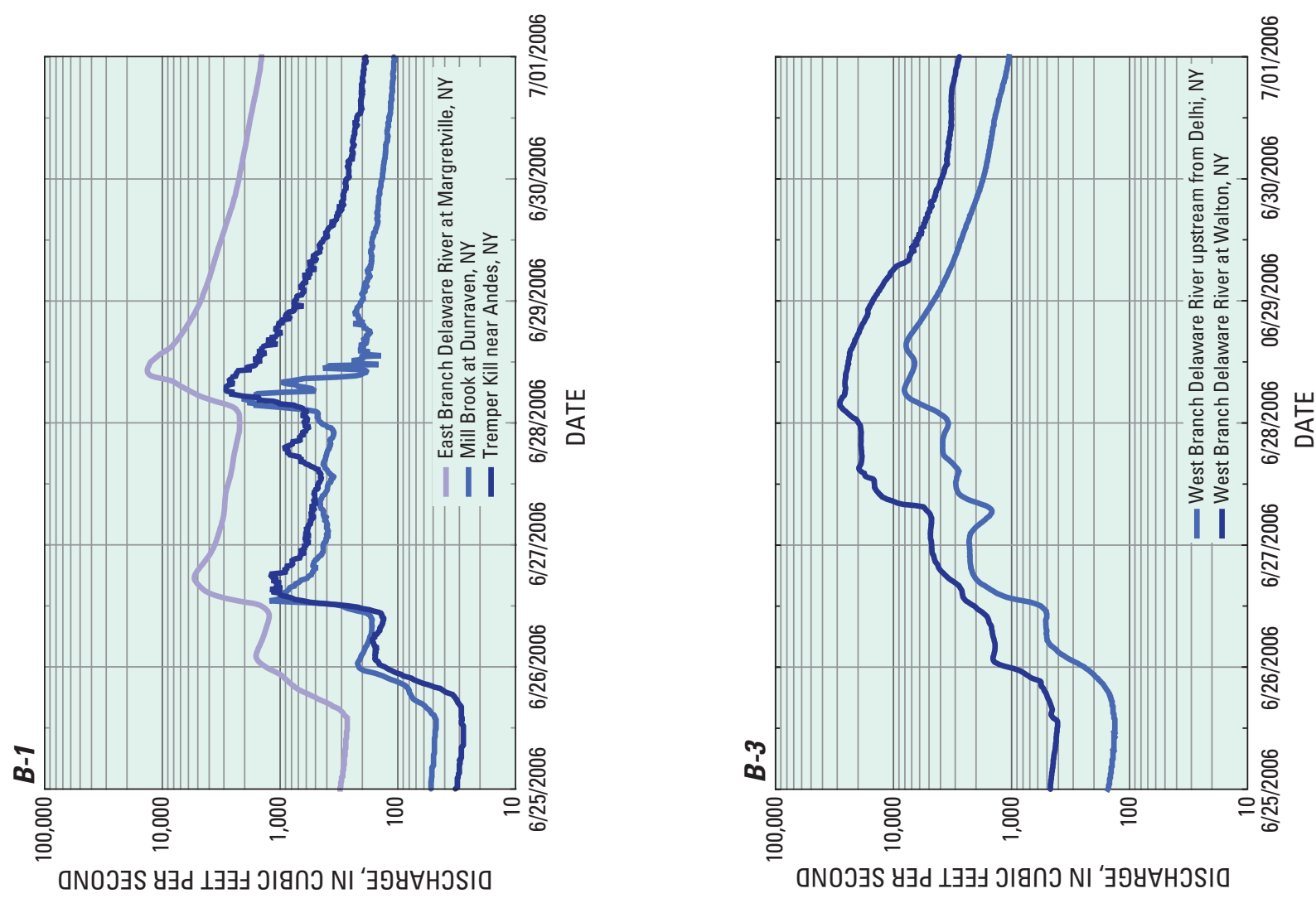

\্ষ

흥ํํ

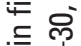

క్య

क号

든

吡

일

ठั.

के

뉴

㱒

穿

它家

$=\underset{T}{\top}$

-

㐫心

든

등

$\sum$
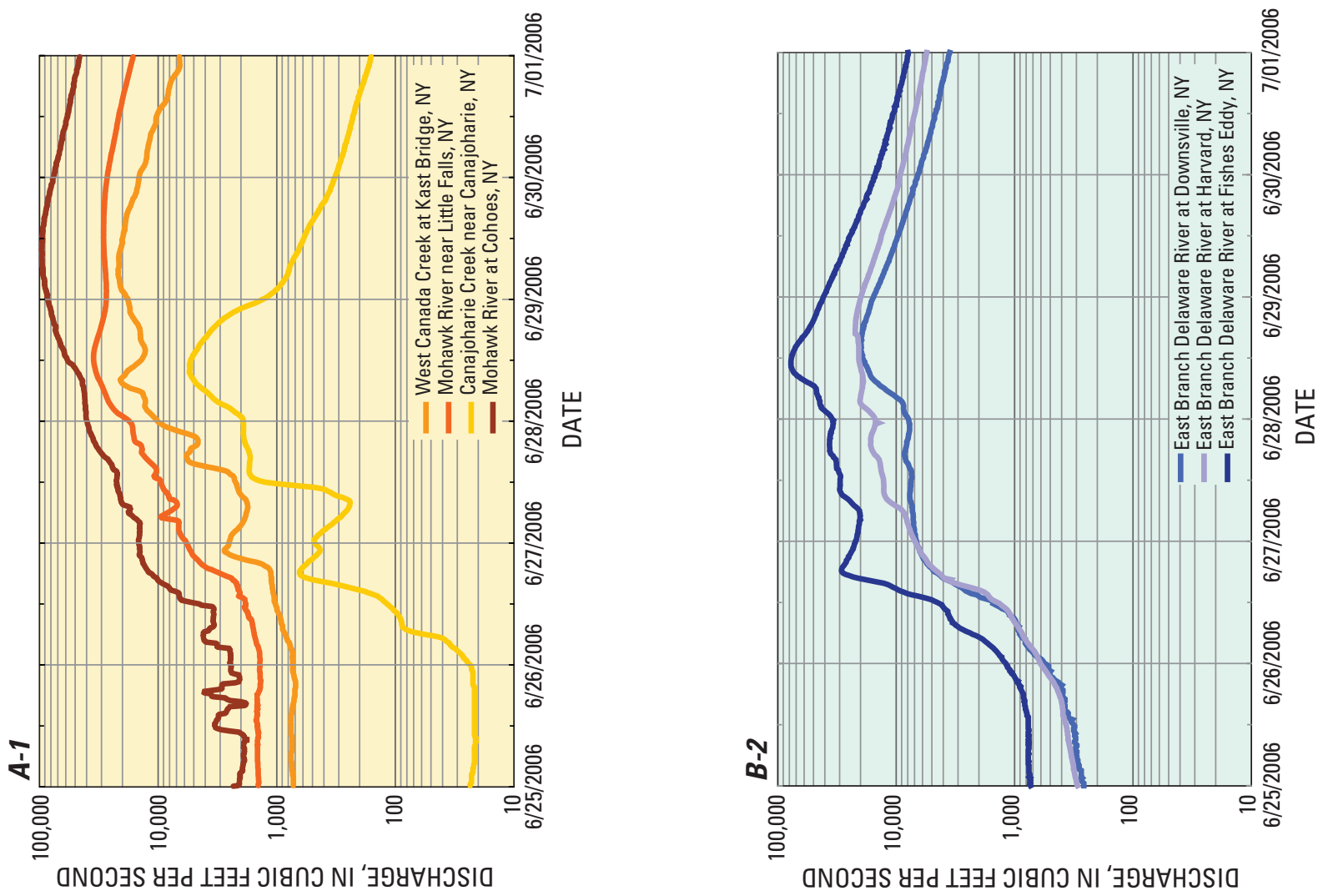

文 产

$\stackrel{ \pm}{\leftrightarrows}$

$\subseteq 3$

.을

要

음

ర্

產

离 宛

몽

创

ᄒう்

등

产

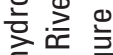

중

민

$\frac{\pi}{2} \sum_{\frac{\pi}{2}}$

员

$\infty$

$\infty$ 禹

言 

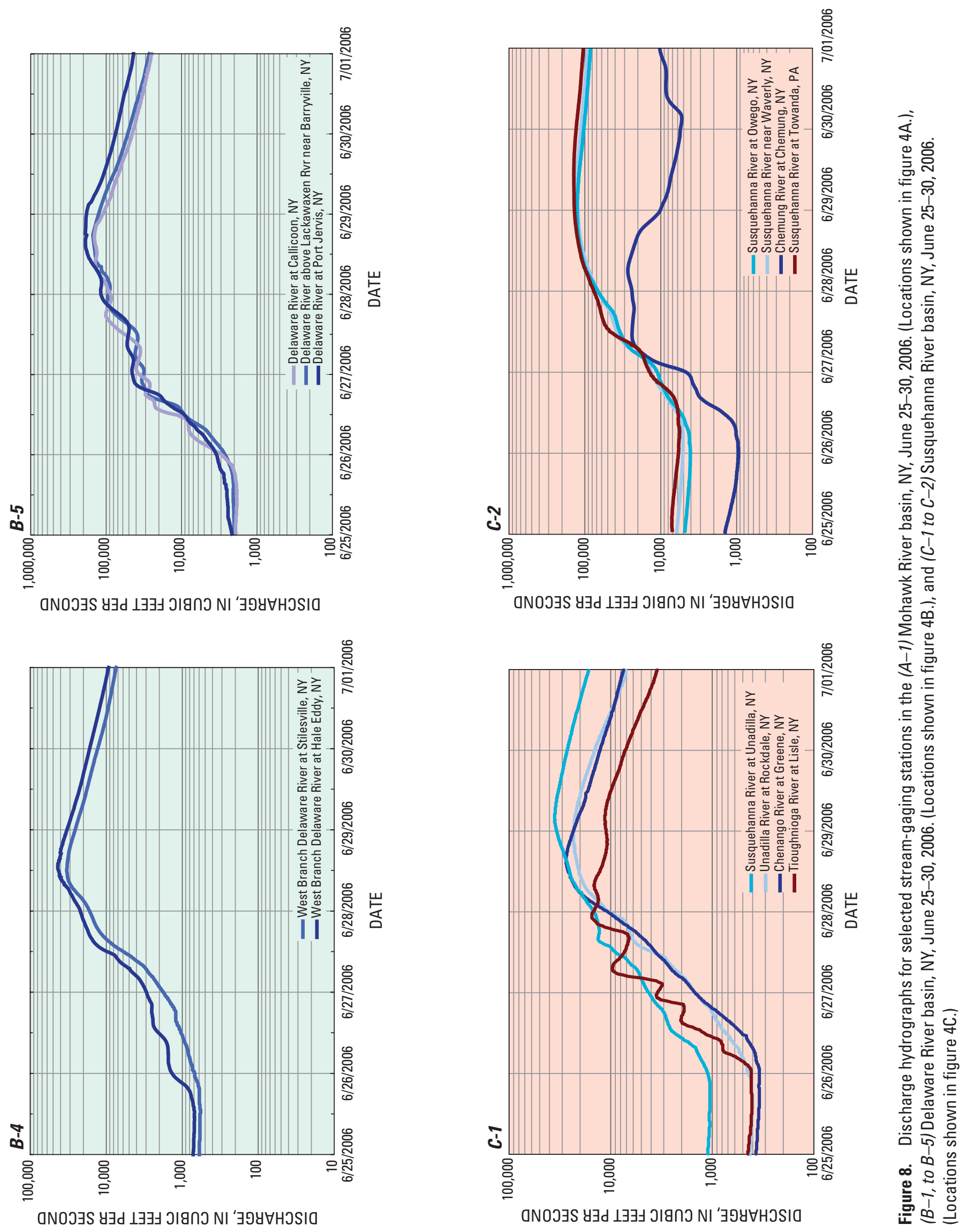
1784 (Grover, 1937; Bailey and others, 1975). Discharge hydrographs for selected USGS stream-gaging stations in the Susquehanna River basin for the period June 25-30, 2006, are shown in figure 8.

\section{Effects of Reservoirs on Flooding}

The streamflow along reaches of the Mohawk, Delaware, and Susquehanna Rivers is affected by the outflow from one or more reservoirs in each basin. Data for the Delta, Hinckley, and Schoharie Reservoirs in the Mohawk River basin; the Pepacton, Cannonsville, Neversink, Prompton, and General Edgar Jadwin Reservoirs and Lake Wallenpaupack in the Delaware River basin; and the East Sidney and Whitney Point Lakes in the Susquehanna River basin are presented below. Reservoir water-level data for Delta Reservoir were provided by the New York State Thruway Authority, and NYCDEP provided the water-level data for the Pepacton, Cannonsville, and Neversink Reservoirs.

\section{Mohawk River Basin}

The Delta and Hinkley Reservoirs are operated and maintained by the New York State Canal Corporation, a division of the New York State Thruway Authority, and were originally constructed for navigation of the Erie Barge canal. Currently, these reservoirs are used for water supply, fisheries, power generation, and canal operations, and there is no provision for the planned regulation or mitigation of floodwaters. The Schoharie Reservoir is operated and maintained by the NYCDEP as a water-supply reservoir and it also does not have any provision for the planned regulation or mitigation of floodwater flows.

Delta Reservoir (fig. 4A) releases water at Delta Dam on the Mohawk River, which is about 4 mi upstream from Rome, NY, and has a drainage area of $148 \mathrm{mi}^{2}$. The dam was completed on August 3, 1912; controlled storage is documented to have started on May 1, 1913. The usable capacity of the reservoir is 2,800 million cubic feet at the crest of the spillway. The spillway crest elevation is $550.0 \mathrm{ft}$, Barge Canal Datum. The maximum observed elevation during 1951 to 2005 was $552.8 \mathrm{ft}$ on June 22, 1972; April 17, 1994; and January 9,1998 . The maximum observed elevation during 2006 was $551.9 \mathrm{ft}$ on June 28 and 29. The USGS streamgaging station Mohawk River below Delta Dam near Rome (01336000) recorded a peak discharge of $3,100 \mathrm{ft}^{3} / \mathrm{s}$ on June 28 , which was less than a 5-year recurrence interval.

The Hinckley Reservoir (fig. 4A) is on West Canada Creek at Hinckley, NY, and has a drainage area of $372 \mathrm{mi}^{2}$. The West Canada Creek is a major tributary to the Mohawk River between Rome and Little Falls. The Hinckley Reservoir began storage operations in March 1914 and is formed by an earth and concrete dam, Hinckley Dam. The usable capacity of the reservoir between the elevations $1,173.5$ and $1,225.0 \mathrm{ft}$, elevation of spillway, is 3,320 million cubic feet. The elevation of the water level in the reservoir on June 26, 2006, was $1,223.0 \mathrm{ft}$, and the reservoir was at 93 percent of capacity (fig 9A-1). The USGS stream-gaging station West Canada Creek at Wilmurt (01343060), upstream from the Hinckley Reservoir, recorded a peak discharge of $23,200 \mathrm{ft}^{3} / \mathrm{s}$ at 12:30 p.m. on June 28. The drainage area upstream from this stream-gaging station is $258 \mathrm{mi}^{2}$, which is about 70 percent of the total contributing area to the Hinckley Reservoir. The peak discharge recorded at this station per unit of contributing drainage area yields a peak runoff of about $90\left(\mathrm{ft}^{3} / \mathrm{s}\right) / \mathrm{mi}^{2}$. Applying this peak runoff to the entire Hinckley Reservoir drainage area yields an estimated maximum inflow of about $33,500 \mathrm{ft}^{3} / \mathrm{s}$ on June 28 . The water level in the Hinckley Reservoir reached a maximum elevation of 1,229.8 ft shortly before midnight on June 28 (fig. 9A-1). The period-of-record maximum elevation of $1,230.2 \mathrm{ft}$ for the Hinckley Reservoir was set on October 2, 1945.

The Schoharie Reservoir (fig. 4A) is located along the Schoharie Creek a few miles east of Grand Gorge, NY, and has a drainage area of $315 \mathrm{mi}^{2}$. The reservoir began storage operations on July 24,1926 , and is formed by a masonary and earth dam. The usable capacity of the reservoir is $19,583 \mathrm{Mgal}$ between the minimum operating elevation of $1,050.0 \mathrm{ft}$ and the crest of the spillway at elevation 1,130.0 ft. On June 26, 2006, the daily mean elevation of the Schoharie Reservoir was $1,121.57 \mathrm{ft}$ (fig. 9A-2). The USGS stream-gaging station Schoharie Creek at Prattsville (01350000), recorded a peak discharge of $19,100 \mathrm{ft}^{3} / \mathrm{s}$ (table 3 ) on June 26 , which was less than a 5 -year recurrence interval, and a secondary peak of $17,500 \mathrm{ft}^{3} / \mathrm{s}$ on June 28 . The drainage area upstream from this stream-gaging station is $237 \mathrm{mi}^{2}$, which is about 75 percent of the total contributing area to the Schoharie Reservoir. The peak discharge recorded at this station per unit of contributing drainage area yields a peak runoff of $81\left(\mathrm{ft}^{3} / \mathrm{s}\right) / \mathrm{mi}^{2}$ on June 26 and $74\left(\mathrm{ft}^{3} / \mathrm{s}\right) / \mathrm{mi}^{2}$ on June 28 . By applying these peak runoffs to the entire Schoharie Reservoir drainage area, an estimated maximum inflow of about $25,500 \mathrm{ft}^{3} / \mathrm{s}$ was computed for June 26 and an estimated maximum inflow of $23,300 \mathrm{ft}^{3} / \mathrm{s}$ for June 28. The water level in the reservoir reached a maximum elevation of 1,131.36 ft for this storm at 1:30 p.m. on June 28. The peak outflow from the reservior was estimated on the basis of the recorded peak discharge at the USGS streamgaging station Schoharie Creek at Gilboa (01350101) to be $17,500 \mathrm{ft}^{3} / \mathrm{s}$ (fig. $9 \mathrm{~A}-2$ ).

\section{Delaware River Basin}

The Pepacton, Cannonsville, and Neversink Reservoirs are operated and maintained by the NYCDEP as water-supply reservoirs. The reservoirs have no provision for the planned regulation or mitigation of floodwaters. In addition, the amount of water that can be diverted through water-supply 


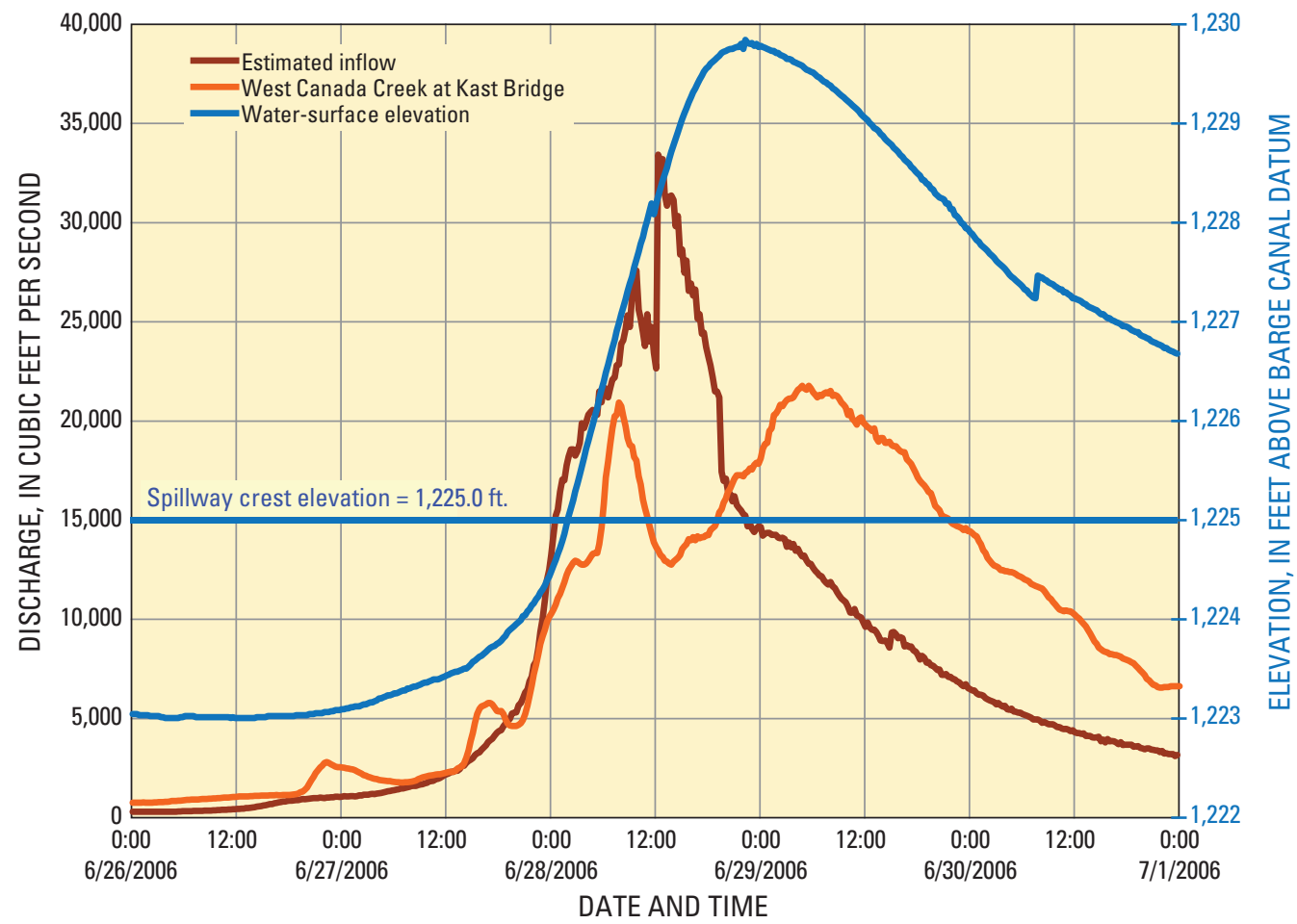

Figure 9A-1. Fifteen minute inflow, and water-surface elevation at the Hinkley Reservoir, NY, June 26-30, 2006.

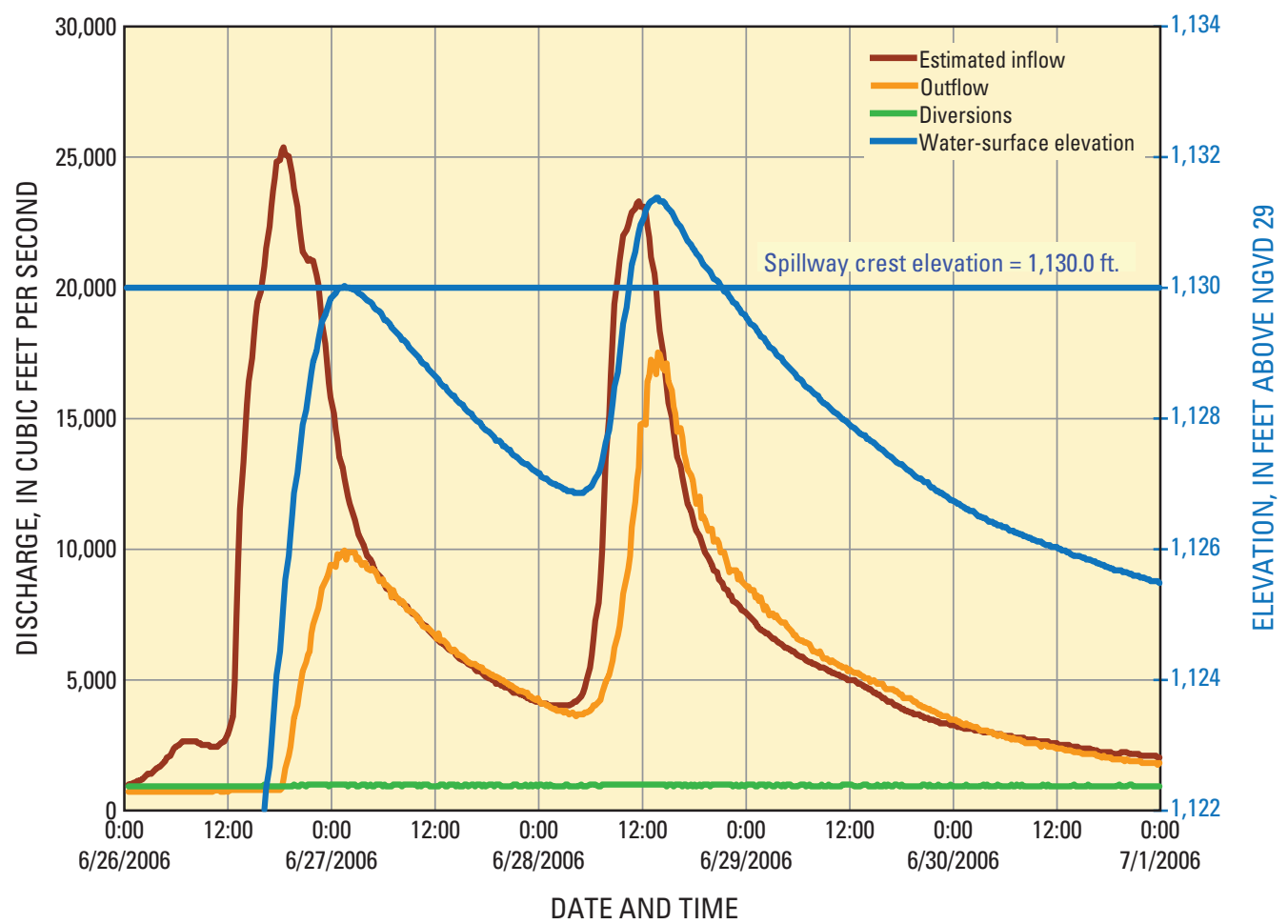

Figure 9A-2. Fifteen minute inflow, outflow, diversions and water-surface elevation at the Schoharie Reservoir, NY, June 26-30, 2006. 
tunnels is inconsequential in comparison to the volume of floodwater flows.

The Pepacton Reservoir (fig. 4b) is located along the East Branch of the Delaware River just upstream from Downsville, $\mathrm{NY}$, and has a drainage area of $372 \mathrm{mi}^{2}$. The Pepacton Reservoir began storage operations on September 15, 1954, and is formed by an earth filled rockfaced dam. The usable capacity of the reservoir is $140,190 \mathrm{Mgal}$, measured between the minimum operating elevation of $1,152.0 \mathrm{ft}$ and the spillway crest at an elevation of 1,280.0 ft. The total capacity at the spillway crest, including dead storage, is 149,799 Mgal.

The Pepacton Reservoir was at about 101 percent of capacity at 7 a.m. on June 26, 2006, and was spilling. The combined streamflow from four USGS stream-gaging stations upstream from the Pepacton Reservoir were used to approximate the inflow to the reservoir during the June 2006 flood. The total drainage area gaged by summing the four USGS stream-gaging stations - East Branch Delaware River at Margaretville(01413500), Platte Kill near Dunraven (01414000), Mill Brook near Dunraven (01414500), and Tremper Kill near Andes (01415000), - is approximately $256 \mathrm{mi}^{2}$. This accounts for about 69 percent of the total contributing area to the Pepacton Reservoir. The hydrographs for these stream-gaging stations were combined to produce an estimated hydrograph of the inflow to the Pepacton Reservoir. The peak runoff, from the estimated inflow hydrograph, per unit of contributing drainage area was then computed to be $70\left(\mathrm{ft}^{3} / \mathrm{s}\right) / \mathrm{mi}^{2}$. Applying this peak runoff to the entire Pepacton Reservoir drainage area yields an estimated maximum inflow of about $26,000 \mathrm{ft}^{3} / \mathrm{s}$ on June 28 (fig. 9B-1).

The water level in the Pepacton Reservoir reached a new period-of-record maximum elevation of $1,283.74 \mathrm{ft}$ on June 28, as a result of this storm (fig. 9B-1). The previous period-of-record maximum observed elevation for the Pepacton Reservoir was 1,283.68 ft recorded on April 3, 2005. The USGS stream-gaging station East Branch Delaware River at Downsville (01417000), immediately downstream from the Pepacton Reservoir, recorded a peak discharge of $20,000 \mathrm{ft}^{3} / \mathrm{s}$ in the early afternoon of June 28 . This is the second highest peak recorded at the USGS stream-gaging station in Downsville since the reservoir began operations in 1954 and the fourth highest peak since the stream-gaging station was installed in July 1941 (fig. 7B-2). Although the Pepacton Reservoir was spilling on June 26, the peak outflow was still attenuated by about 23 percent because of the storage effect of the reservoir.

During flooding events in recent years, the contents of the Pepacton Reservoir have been at various levels at the start of each event. Prior to the flood of January 19-20, 1996, the Pepacton Reservoir was at 58 percent of capacity. During the January 1996 flood, the water level in the Pepacton reservoir rose nearly $20 \mathrm{ft}$, and the peak inflow to the reservoir was estimated to be greater than $50,000 \mathrm{ft}^{3} / \mathrm{s}$ (Lumia, 1998). The period-of-record maximum discharge at the East Branch Delaware River at Margaretville stream-gaging station is $25,800 \mathrm{ft}^{3} / \mathrm{s}$ recorded on January 19, 1996 (fig. 7B-1). The
East Branch Delaware River at Margaretville stream-gaging station is upstream from the Pepacton Reservoir and gages about 44 percent of the contributing drainage area to the reservoir. The outflow during the time of the peak inflow was about $1,800 \mathrm{ft}^{3} / \mathrm{s}$. The recorded peak discharge at the East Branch Delaware River at Downsville stream-gaging station, just downstream from the reservoir, was less than $2,600 \mathrm{ft}^{3} / \mathrm{s}$ during the flood of January 18-19, 1996. Prior to the flood of September 18-19, 2004, the Pepacton Reservoir was at 99.2 percent of capacity. During the September 2004 flood, the peak inflow to the Pepacton Reservoir was estimated to be about 37,500 ft³ $/ \mathrm{s}$ on September 18, 2004 (Brooks, 2005). The recorded peak discharge at the East Branch Delaware River at Downsville stream-gaging station was $18,000 \mathrm{ft}^{3} / \mathrm{s}$ on September 18, 200.

The Cannonsville Reservoir (fig. 4B) located along the West Branch of the Delaware River approximately $1.8 \mathrm{mi}$ southeast of Stilesville, NY, has a drainage area of $454 \mathrm{mi}^{2}$. The Cannonsville Reservoir is formed by an earth filled, rockfaced dam and began storage operations on September 30,1963. The usable capacity of the reservoir is 95,706 Mgal between the minimum operating elevation of $1,040.00 \mathrm{ft}$ and the spillway crest elevation of $1,150.00 \mathrm{ft}$. The total capacity at the spillway crest, including dead storage, is 98,618 Mgal.

The Cannonsville Reservoir was at 101 percent of capacity at 7 a.m. on June 26, 2006, and was spilling. The inflow to the Cannonsville Reservoir was approximated by combining the hydrographs for the USGS stream-gaging stations on the two major tributaries to the reservoir. The total drainage area gaged by the USGS stream-gaging stations West Branch Delaware River at Walton (01423000) and Trout Creek near Trout Creek (0142400103) is approximately 352 $\mathrm{mi}^{2}$. This accounts for about 78 percent of the contributing drainage area of the Cannonsville Reservoir. The hydrograph of estimated inflow developed by combining the individual hydrographs of the West Branch Delaware River at Walton and Trout Creek near Trout Creek stream-gaging stations produced an estimated peak runoff per unit of contributing drainage area of $87\left(\mathrm{ft}^{3} / \mathrm{s}\right) / \mathrm{mi}^{2}$. Applying this peak runoff to the entire Cannonsville Reservoir drainage area yields an estimated maximum inflow of about $39,500 \mathrm{ft}^{3} / \mathrm{s}$ on June 28 (fig. 9B-2). The peak discharges of $28,600 \mathrm{ft}^{3} / \mathrm{s}$ on June 28 at West Branch Delaware River at Walton (fig. 7B-6) and 4,350 ft 3 /s on June 27 at Trout Creek near Trout Creek were both period-ofrecord maximum discharges.

The water level in the Cannonsville Reservoir reached a new period-of-record maximum elevation of 1,160.08 $\mathrm{ft}$ on June 28, as a result of this storm (fig. 9B-2). The previous period-of-record maximum observed elevation was $1,156.79 \mathrm{ft}$ recorded on April 4, 2005. The USGS streamgaging station West Branch Delaware River at Stilesville (01425000), immediately downstream from the Cannonsville Reservoir, recorded a new period-of-record maximum discharge of 33,100 ft $3 / \mathrm{s}$ at noon of June 28 (fig. 7B-7). This new maximum discharge is more than double the previous 


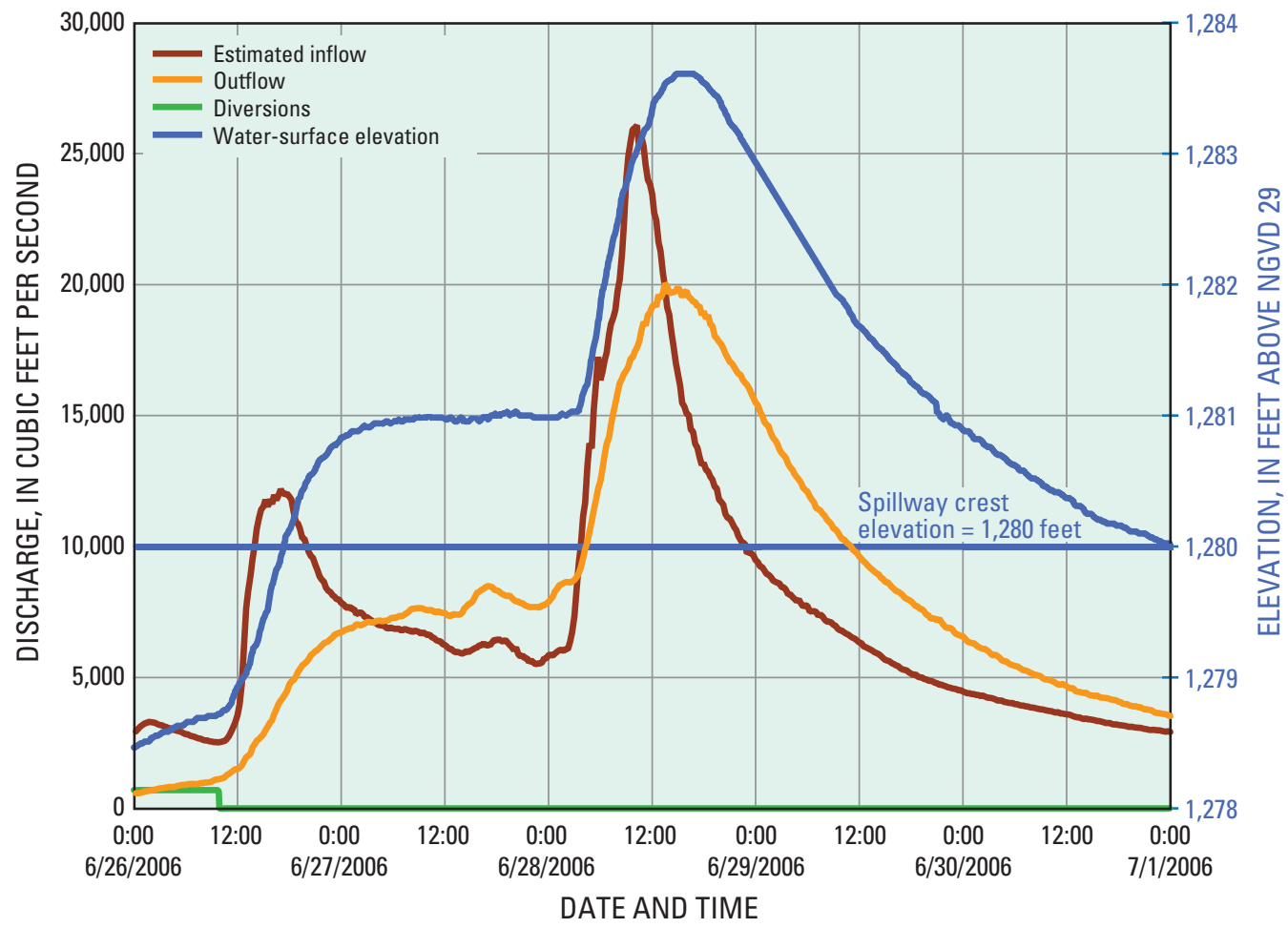

Figure 9B-1. Fifteen minute inflow, outflow, diversions and water-surface elevation at the Pepacton Reservoir, NY, June 26-30, 2006.

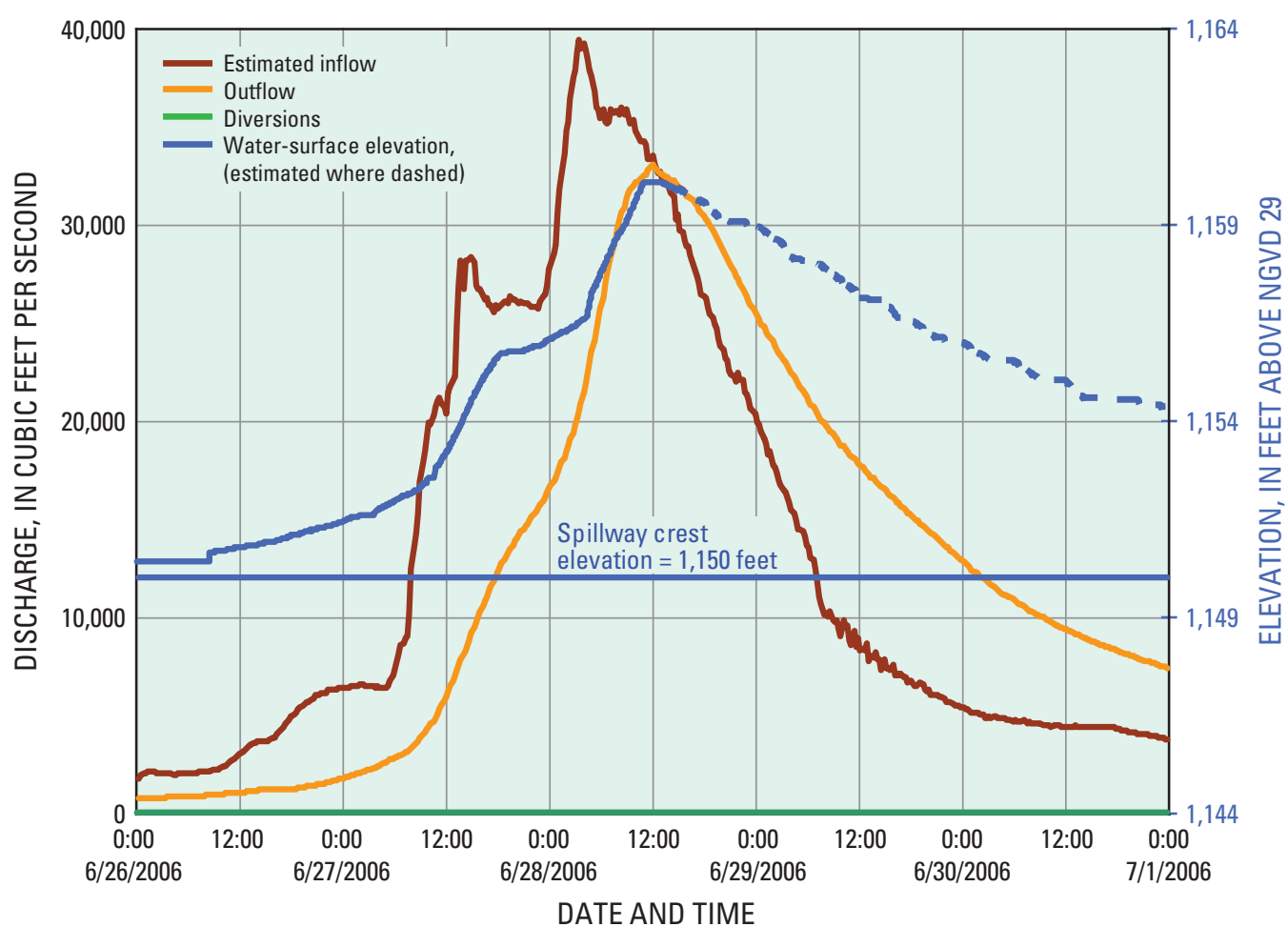

Figure 9B-2. Fifteen minute inflow, outflow, diversions and water-surface elevation at the Cannonsville Reservoir, NY, June 26-30, 2006. 
peak-of-record maximum, since regulation, recorded on April 3, 2005. The peak outflow during the June 2006 flood was reduced by about 16 percent because of the storage effect of the reservoir. Although the Cannonsville Reservoir was full and spilling at the start of this storm, the flooding downstream would have been even greater if the reservoir had not been present.

The contents of the Cannonsville Reservoir were at varying amounts of full capacity at the start of past flooding events. Prior to the flood of January 19-20, 1996, the Cannonsville Reservoir was at 65 percent of full capacity. The water level in the Cannonsville Reservoir rose nearly $23 \mathrm{ft}$ during the flood of January 1996 but did not spill as it stored floodwaters from the West Branch of the Delaware River and protected downstream communities from devastating flooding. The peak discharge of $25,000 \mathrm{ft}^{3} / \mathrm{s}$ recorded on January 19, 1996, at the West Branch Delaware River at Walton stream-gaging station (01423000) upstream from the reservoir is the second highest peak recorded at this station. Prior to the flood of September 18-19, 2004, the Cannonsville Reservoir was at 99.6 percent of capacity. Upstream from the reservoir at the West Branch Delaware River at Walton streamgaging station, a peak discharge of $15,200 \mathrm{ft}^{3} / \mathrm{s}$ was recorded on September 18, 2004; downstream from the reservoir at West Branch Delaware River at Stilesville, a peak discharge of 10,200 ft $3 / \mathrm{s}$ was recorded on September 19, 2004.

The Neversink Reservoir (fig. 4B) is along the Neversink River approximately 2 mi southeast of Neversink, NY, and has a drainage area of $92.5 \mathrm{mi}^{2}$. The reservoir is formed by an earth filled rockfaced dam and began storage operations on June 2, 1953. The Neversink Reservoir has a usable capacity of 34,941 Mgal between the minimum operating elevation of $1,319.0 \mathrm{ft}$ and the spillway crest elevation of $1,440.0 \mathrm{ft}$. The total capacity at the spillway crest, including dead storage, is 37,146 Mgal.

The contents of the Neversink Reservoir were at about 95 percent of capacity at 7:00 a.m. on June 26, 2006. The USGS stream-gaging station Neversink River near Claryville (01435000) recorded a peak discharge of $11,500 \mathrm{ft}^{3} / \mathrm{s}$ on the morning of June 28. The drainage area above this streamgaging station is about 72 percent of the total contributing area to the Neversink Reservoir. The peak discharge recorded at this station per unit of contributing drainage area yields a peak runoff of $173\left(\mathrm{ft}^{3} / \mathrm{s}\right) / \mathrm{mi}^{2}$. Applying this peak runoff to the entire Neversink Reservoir drainage yields an estimated maximum inflow of $16,000 \mathrm{ft}^{3} / \mathrm{s}$ to the reservoir on June 28 (fig. 9B-3).

The Neversink Reservoir reached a peak elevation of $1,442.76 \mathrm{ft}$ on June 28 as a result of this storm. The periodof-record maximum elevation for the Neversink Reservoir is 1,443.66 ft recorded on April 3, 2005. The USGS streamgaging station Neversink River at Neversink (01436000), just downstream from the Neversink Reservoir, recorded a peak discharge of $7,840 \mathrm{ft}^{3} / \mathrm{s}$ on the morning of June 28 . The periodof-record maximum discharge at this station, since regulation, is 12,500 ft $3 / \mathrm{s}$ recorded during the flood of April 2-3, 2005.

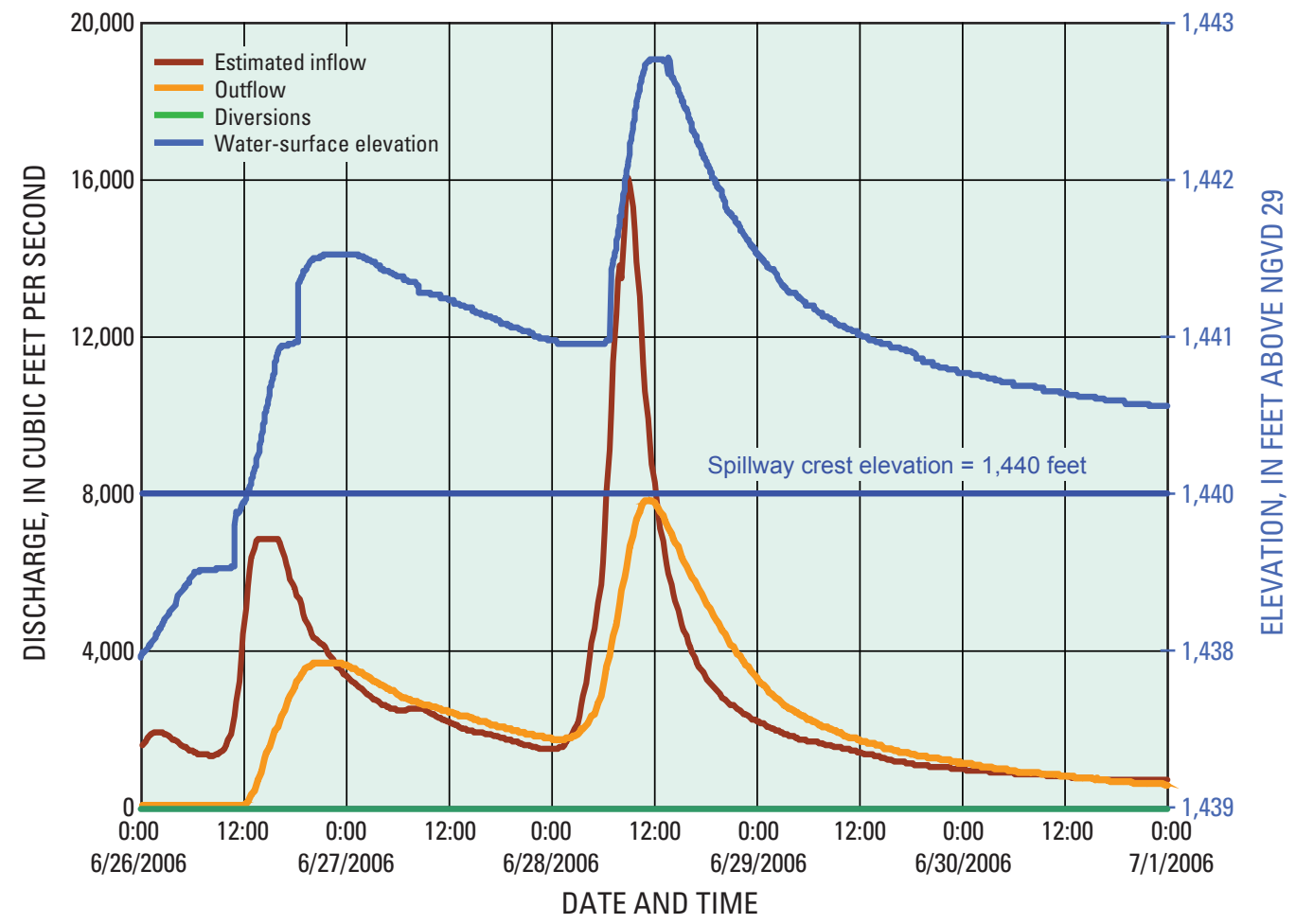

Figure 9B-3. Fifteen minute inflow, outflow, diversions and water-surface elevation at the Neversink Reservoir, NY, June 26-30, 2006. 
The peak outflow from the Neversink Reservoir on June 28 was attenuated by about 51 percent because of the storage effects of the reservoir.

The Prompton Reservoir is along the West Branch Lackawaxen River 0.3 mi north of Prompton, PA, and has a drainage area of $59.6 \mathrm{mi}^{2}$. The reservoir is formed by an earth and rock filled dam and was completed by the U.S. Army Corps of Engineers in July 1960. The primary purpose for the construction of this reservoir was flood control, although it is also used for recreation. Regulation is accomplished through an ungated tunnel that slowly drains stored floodwaters. The usable capacity of the reservoir is about 15,732 Mgal between elevation 1,125.0 ft (conservation pool) and the spillway crest at elevation $1,205.0 \mathrm{ft}$.

The water level in the Prompton Reservoir was at an elevation of 1,124.1 ft at noon on June 25, 2006. During this storm event, the water level in the reservoir rose more than $32 \mathrm{ft}$ and crested at 1,156.4 ft on June 28 at 3:00 p.m., nearly $49 \mathrm{ft}$ below the spillway. The Prompton Reservoir successfully stored 4,272 Mgal of floodwaters, or 4.1 in. of runoff, during the June 2006 storm.

The General Edgar Jadwin Reservoir is along Dyberry Creek, a major tributary to the Lackawaxen River, $2.4 \mathrm{mi}$ north of Honesdale, PA, and has a drainage area of $64.5 \mathrm{mi}^{2}$. The reservoir is formed by an earth and rock filled dam and was completed by the U.S. Army Corps of Engineers in October 1959. The primary purpose for the construction of this reservoir was flood control. Regulation is accomplished through an ungated tunnel that slowly drains stored floodwaters. The usable capacity of the reservoir is about 7,983 Mgal below the spillway crest at elevation 1,053.0 ft, and there is no dead storage.

The water level in the General Edgar Jadwin Reservoir was at an elevation of $989.2 \mathrm{ft}$ at noon on June 25, 2006. During the storm, the water level rose nearly $52 \mathrm{ft}$ and crested at $1,040.8 \mathrm{ft}$ on June 28 at 8:00 p.m., slightly more than $12 \mathrm{ft}$ below the spillway. The General Edgar Jadwin Reservoir successfully stored 5,429 Mgal, or $4.8 \mathrm{in}$. of runoff, during the June 2006 storm.

Lake Wallenpaupack is along Wallenpaupack Creek (fig. 4B), a major tributary to the Lackawaxen River, at Wilsonville, PA, and has a drainage area of $228 \mathrm{mi}^{2}$. The lake is formed by a concrete gravity-type and earth filled dam and was completed by Pennsylvania Power and Light Corporation (PPL) in November 1925. The primary purpose of the lake was hydroelectric power, although it is also used for recreation, and is operated in a manor to mitigate downstream flooding. Regulation is accomplished by 14 - $\mathrm{ft}$ diameter roller gates affixed on top of the spillway crest at elevation $1,176.0 \mathrm{ft}$ and by the intake structure for two turbines. The usable capacity of the lake is $38,000 \mathrm{Mgal}$ between elevation $1,165.0 \mathrm{ft}$ and the crest elevation of $1,187.0 \mathrm{ft}$ (PPL Generation, LLC, and Kleinschmidt, 2002).

On June 25, 2006, the water level in Lake Wallenpaupack was at a normal operating elevation of 1,185.8 ft; by 3:30 a.m. on June 28 , the water level in the lake had risen to an elevation of 1,190.1 ft and began to spill over the top of the roller gates. On June 28, a 4-hour average peak inflow of $19,500 \mathrm{ft}^{3} / \mathrm{s}$ was estimated and a peak outflow of $9,700 \mathrm{ft}^{3} / \mathrm{s}$ was computed. Lake Wallenpaupack successfully stored 11,500 Mgal, or 2.9 in. of runoff, during the June 2006 storm (Gary Petrewski, Pennsylvania Power and Light Corporation, oral commun., 2008).

\section{Susquehanna River Basin}

The East Sidney Lake (fig. 4C) is along the Ouleout Creek about 4 mi upstream from its confluence with the Susquehanna River near Unadilla, NY, and has a drainage area of $103 \mathrm{mi}^{2}$. The Ouleout Creek is a major tributary to the Susquehanna River between Oneonta and Unadilla. East Sidney Lake is formed by a concrete dam and rock-filled dike. The primary purpose for the construction of this lake was flood control, although it is also used for recreation. While still under construction, East Sidney Lake began regulation of outflows in November 1949 and was first used for flood control on March 28, 1950. The U.S. Army Corps of Engineers completed construction of the reservoir in June 1950. Discharge is controlled by the operation of five large gates, which allow the lake to store floodwaters during storms and then release water when conditions permit. The usable capacity of the lake is about 10,934 Mgal between elevation $1,115.0 \mathrm{ft}$ and the crest of the spillway at elevation $1,203.0 \mathrm{ft}$.

The water level in East Sidney Lake was at an elevation of 1,152.4 ft at 7:00 a.m. on June 26, 2006, 10 percent of capacity. The discharge at the USGS stream-gaging station Ouleout Creek at East Sidney (01500000), downstream from the lake, was less than $100 \mathrm{ft}^{3} / \mathrm{s}$ on the morning of June 26, 2006. Releases from the lake were increased to about $1,000 \mathrm{ft}^{3} / \mathrm{s}$ by late in the evening on June 26 in an attempt to lower the water level in the lake to allow a larger void to store floodwaters. When rainfall increased on the morning of June 27, releases from the lake were reduced, and by noon on June 27, the discharge was less than $40 \mathrm{ft}^{3} / \mathrm{s}$ at the Ouleout Creek at East Sidney stream-gaging station. From 5:00 a.m. on June 27 to 5:00 a.m on June 29, the water level in East Sidney Lake had risen more than $50 \mathrm{ft}$, and the lake was starting to spill (fig. 9C-1). This was the first time in its 56-year history that the lake spillway had been used. The water level in East Sidney Lake reached a new period-of-record maximum elevation of 1,204.35 ft on June 30. The peak discharge at the Ouleout Creek at East Sidney stream-gaging station was 2,010 ft $3 / \mathrm{s}$ recorded on July 1, 2006, days after flood crests along the Susquehanna River had occurred. The East Sidney Lake successfully stored 11,110 Mgal, or 6.2 in. of runoff, during the June 2006 storm.

The Otselic River is a tributary to the Tioughnioga River, which is a tributary to the Chenango River. The Chenango River is a major tributary to the Susquehanna River, whose confluence is in the City of Binghamton. Whitney Point Lake 
(fig. 4C) is along the Otselic River about 0.9 mi upstream from the confluence with the Tioughnioga River in Whitney Point, $\mathrm{NY}$, and has a drainage area of $257 \mathrm{mi}^{2}$. The Tioughnioga River at Lisle stream-gaging station (01509520) is upstream from the confluence, and the Tioughnioga River at Itaska stream-gaging station (01511500) is downstream from the confluence (fig. 4C). Whitney Point Lake was completed by the U.S. Army Corps of Engineers in 1942 and is formed by an earth filled dam and concrete spillway. The primary purpose for the construction of this lake was flood control, and it was first used for this purpose on March 9, 1942. Discharge is controlled by the operation of three large gates, which are used to allow the lake to store floodwaters during storms and then release them when conditions permit. The usable capacity of the lake is about 28,171 Mgal between elevation $950.0 \mathrm{ft}$ and the crest of the spillway at elevation 1,010.0 ft.

The water level in Whitney Point Lake was at an elevation of $973.2 \mathrm{ft}$ at 7:00 a.m. on June 26, 2006, 15 percent of capacity. Streamflow at the USGS stream-gaging station Otselic River at Cincinnatus (01510000), about $12 \mathrm{mi}$ upstream from Whitney Point Lake, recorded a peak discharge of $8,100 \mathrm{ft}^{3} / \mathrm{s}$ at 1:00 a.m. on June 28 (table 3). The water level in Whitney Point Lake began a steady rise late in the evening on June 26 and reached a maximum elevation of $999.57 \mathrm{ft}$ at 9:00 a.m. on June 30. Although the water level in Whitney Point Lake had increased by more than $26 \mathrm{ft}$ from June 26 to June 30 , there was still an additional $10 \mathrm{ft}$ of storage available before the lake would spill (fig. 9C-2). Whitney Point Lake successfully stored 18,987 Mgal, or 4.3 inches of runoff, during the June 2006 storm.

\section{Comparison of the 2006 Flood to Historic Floods}

For more than a century, the USGS has documented the effects of many floods that have devastated areas in New York and adjacent states. Although the data collected from previous floods has helped Federal, State, and local officials to develop infrastructure to withstand future flooding, a comparison of this flood with past floods gives a perspective on the magnitude of this event that is not affected by changes in costs and labor practices over time. The recorded peak water-surface elevations and discharges during the June 26-29, 2006, flood at selected USGS stream-gaging stations were compared to those of several previous floods. The floods selected for comparison differed by basin because of the diverse topography and variable weather patterns typically found in New York. New York has eight physiographic regions, excluding Long Island, and widely varied mean annual precipitation patterns (Randall, 1996) that at times can contribute to widely varied streamflow conditions. It is not uncommon in New York for one part of the state to experience a major flood, while rivers and streams in other areas remain well below the NWS flood stage.

\section{Mohawk River Basin}

In the Mohawk River basin, peak discharges from the June 2006 flood were compared to historic peaks from the floods of March 1977 and January 1996 at selected USGS stream-gaging stations (table 4A). During the March 1977 flood, the USGS stream-gaging station Mohawk River below Delta Dam near Rome (01336000) recorded a peak discharge of $640 \mathrm{ft}^{3} / \mathrm{s}$, which is less than the 2-year recurrence interval, but downstream at the Mohawk River at Little Falls streamgaging station (01347000), the recorded peak discharge for the March 1977 flood was 33,100 $\mathrm{ft}^{3} / \mathrm{s}$. During the January 1996 flood, a peak discharge of $30,700 \mathrm{ft}^{3} / \mathrm{s}$ was recorded at the Mohawk River at Little Falls stream-gaging station. The West Canada Creek is a major tributary to the Mohawk River between Rome and Little Falls. During the 1977 and 1996 floods, the recorded peak discharges at the USGS streamgaging station West Canada Creek at Kast Bridge (01346000) were 2,850 and 13,600 ft $3 / \mathrm{s}$, respectively. Farther downstream from Little Falls, two additional gaged tributaries contribute to the flow in the Mohawk River. These tributaries are the East Canada Creek and the Schoharie Creek. The USGS streamgaging stations East Canada Creek at East Creek (01348000) and Schoharie Creek at Burtonsville (01351500) recorded peak discharges of 13,300 and $35,500 \mathrm{ft}^{3} / \mathrm{s}$, respectively, during the March 1977 flood and 17,000 and 81,600 ft $3 / \mathrm{s}$, respectively, during the January 1996 flood. The USGS stream-gaging station Mohawk River at Cohoes (01357500) , near the mouth of the Mohawk River, recorded peak discharges of 112,000 and 132,000 ft³ during the March 1977 and January 1996 floods, respectively. Discharge hydrographs for selected historic floods at the Little Falls and Cohoes stream-gaging stations are shown in figure 10A.

During the June 2006 flood, new period-of-record maximum discharges were recorded at the Mohawk River at Little Falls and the East Canada Creek at East Creek streamgaging stations, and although a new record maximum was not recorded at the West Canada Creek at Kast Bridge streamgaging station, the maximum discharge did have a greater than 100-year recurrence interval (table 3). The maximum discharge for the June 2006 flood recorded at the USGS stream-gaging station Schoharie Creek at Burtonsville was $28,100 \mathrm{ft}^{3} / \mathrm{s}$ with a recurrence interval of less than 5 years.

\section{Delaware River Basin}

In the Delaware River basin, peak discharges from the June 2006 flood were compared to historic peaks from the floods of August 1955, January 1996, September 2004, and April 2005 at selected USGS stream-gaging stations (table 4B). Prior to June 2006, the August 1955 flood was considered by many to be the greatest flood that ever occurred along many reaches of the main stem of the Delaware River from Hancock, NY, to Trenton, NJ, as well as many parts of southeastern New England. The flood of August 1955 was 


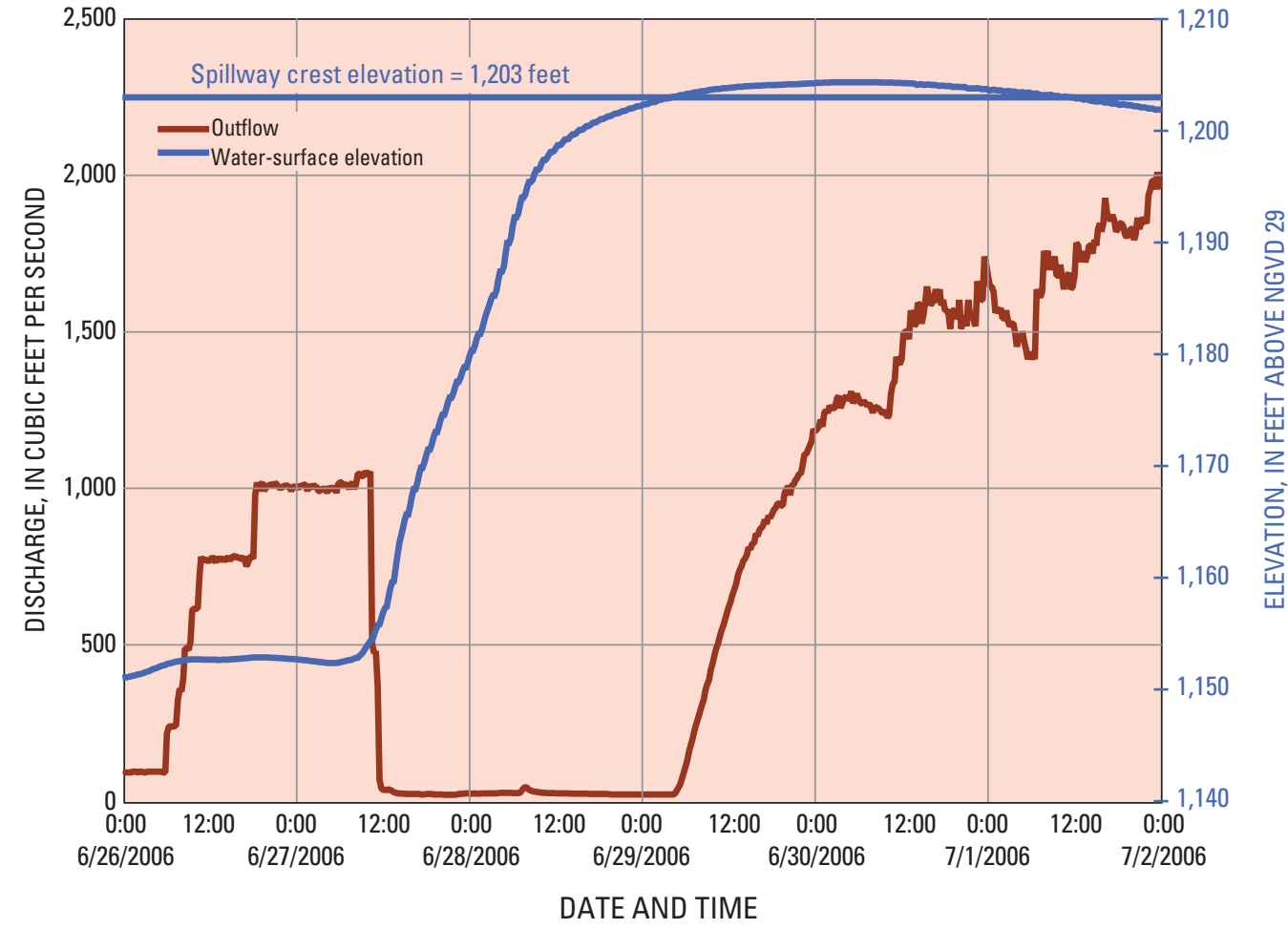

Figure 9C-1. Fifteen minute outflow and water-surface elevation at the East Sidney Lake, NY, June 26-July 1, 2006.

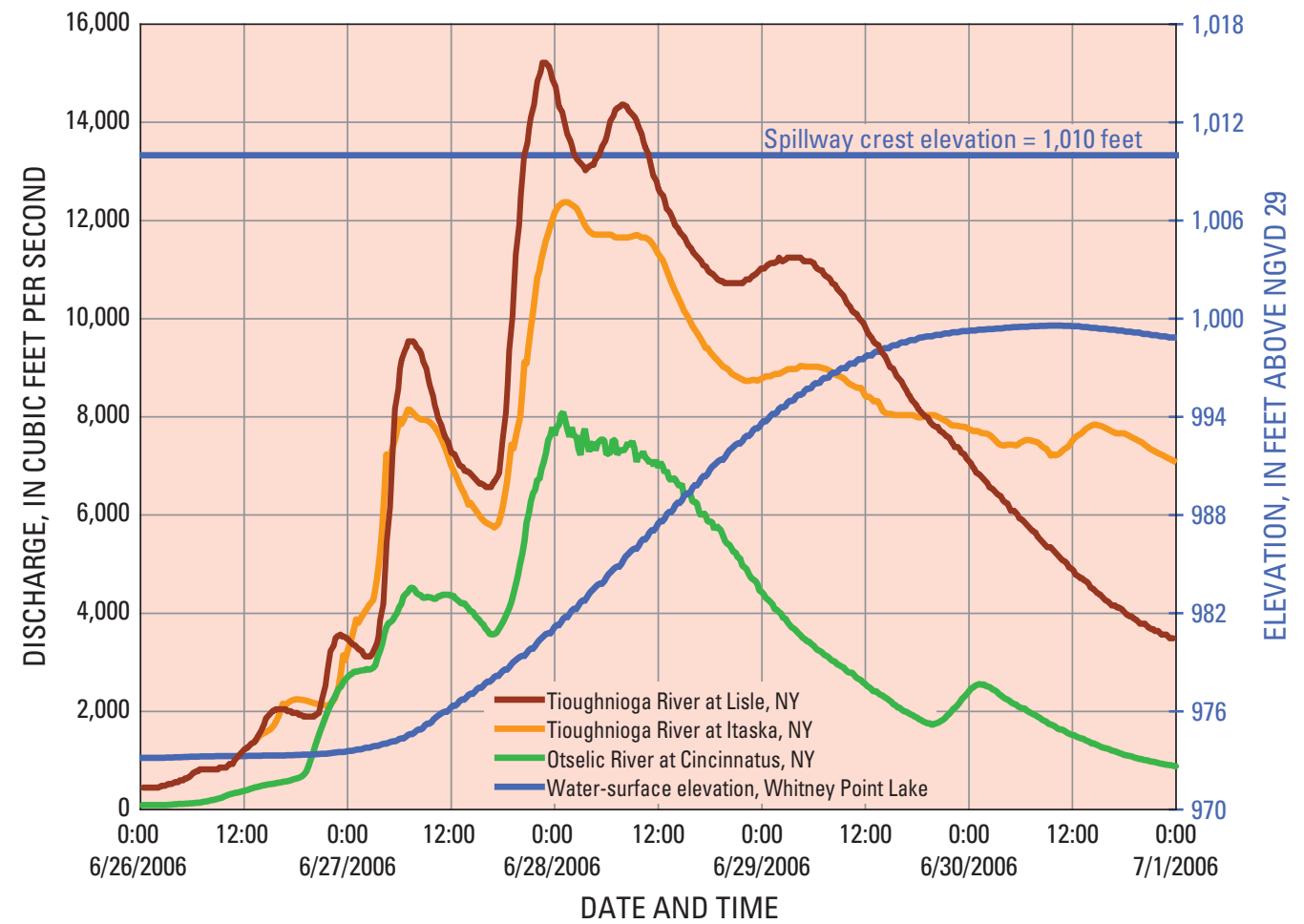

Figure 9C-2. Fifteen minute discharges at selected stream-gaging stations upstream and downstream of Whitney Point Lake and water-surface elevation at Whitney Point Lake, NY, June 26-30, 2006. 

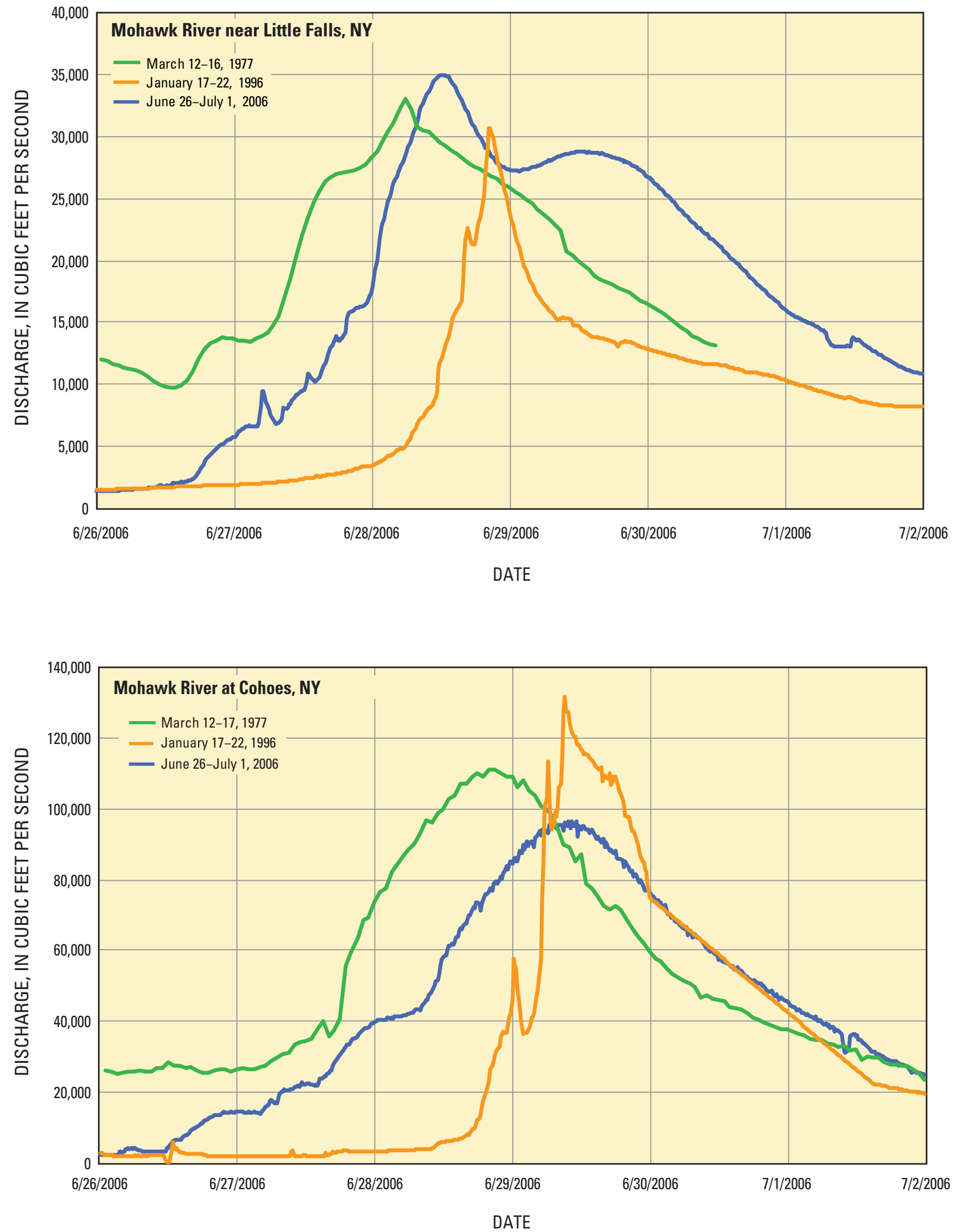

Figure 10A. Discharge hydrographs for selected historic floods at (1) the Mohawk River near Little Falls, NY, and (2) the Mohawk River at Cohoes, NY, stream-gaging stations. (Locations shown in fig. 4A.) 
Table 4A. Peak elevations and peak discharges for selected historical floods and the June 26-29, 2006, flood at selected U.S. Geological Survey stream-gaging stations in the Mohawk River basin, NY.

$\left[\mathrm{mi}^{2}\right.$, square miles; -- , no data available]

\begin{tabular}{|c|c|c|c|c|c|}
\hline \multirow{2}{*}{$\begin{array}{l}\text { Station } \\
\text { number }\end{array}$} & \multirow{2}{*}{$\begin{array}{l}\text { Station } \\
\text { name }\end{array}$} & \multirow{2}{*}{$\begin{array}{c}\text { Drainage } \\
\text { area } \\
\left(\mathrm{mi}^{2}\right)\end{array}$} & \multicolumn{3}{|c|}{$\begin{array}{l}\text { Peak elevations, in feet above NGVD 29; } \\
\text { peak discharges, in cubic feet per second }\end{array}$} \\
\hline & & & March 1977 & January 1996 & June 2006 \\
\hline 01336000 & Mohawk River below Delta Dam, near Rome, NY & 152 & $476.05 ; 640$ & $476.27 ; 804$ & $479.73 ; 3,100$ \\
\hline 01346000 & West Canada Creek at Kast Bridge, NY & 560 & $442.73 ; 2,850$ & $445.81 ; 13,600$ & $447.28 ; 21,800$ \\
\hline 01347000 & Mohawk River near Little Falls, NY & 1,342 & $328.01 ; 33,100$ & $327.31 ; 30,700$ & $328.56 ; 35,000$ \\
\hline 01348000 & East Canada Creek at East Creek, NY & 289 & $343.12 ; 13,300$ & $344.02 ; 17,000$ & $346.69 ; 31,500$ \\
\hline 01349150 & Canajoharie Creek near Canajoharie, $\mathrm{NY}$ & 59.7 & -- & $648.51 ; 3,280$ & $650.50 ; 5,510$ \\
\hline 01351500 & Schoharie Creek at Burtonsville, NY & 886 & $515.87 ; 35,500$ & $520.86 ; 81,600$ & $514.95 ; 28,100$ \\
\hline 01357500 & Mohawk River at Cohoes, NY & 3,450 & $70.89 ; 112,000$ & $71.81 ; 132,000$ & $69.83 ; 96,400$ \\
\hline
\end{tabular}

fueled by two hurricanes that traveled up the east coast and over New York and southeastern New England. Hurricanes Connie and Diane hit the area about 1 week apart, and each dropped about 4 to 8 in. of rain over parts of southeastern New York. The USGS stream-gaging station Delaware River above Lackawaxen River near Barryville, NY, (01428500) has been in operation since October 1940, and prior to the June 28, 2006 , peak of $151,000 \mathrm{ft}^{3} / \mathrm{s}$, the period-of-record maximum discharge was 130,000 ft $\mathrm{ft}^{3} / \mathrm{s}$ recorded during the August 1955 flood (fig. 7B-10). The period-of-record maximum discharge at the USGS stream-gaging station Delaware River at Port Jervis (01434000), in operation since October 1904 , is $233,000 \mathrm{ft}^{3} / \mathrm{s}$, which was recorded during the August 1955 flood. The peak discharge for the June 2006 flood at the Delaware River at Port Jervis stream-gaging station was $189,000 \mathrm{ft}^{3} / \mathrm{s}$ (fig. 7b-11). According to historic literature, the highest flood prior to the October 1903 flood which was estimated at $205,000 \mathrm{ft}^{3} / \mathrm{s}$ at Port Jervis, was on January 8, 1841 (Grover, 1937). The Lackawaxen and Mongaup Rivers and Shohola Creek are the larger tributaries between the near Barryville and Port Jervis stream-gaging stations, and the Lackawaxen River accounts for 57 percent of the increase in drainage area between the two stream-gaging stations. During the August 1955 flood, the peak discharge at the USGS stream-gaging station Lackawaxen River near Hawley, PA, (01431500) was 51,900 $\mathrm{ft}^{3} / \mathrm{s}$, and during the June 2006 flood, the peak discharge was $28,000 \mathrm{ft}^{3} / \mathrm{s}$. Inflow during the August 1955 flood, to the Delaware River between Barryville and Port Jervis can be estimated to be about $100,000 \mathrm{ft}^{3} / \mathrm{s}$, but during the June 2006 flood, the inflow was probably less than $40,000 \mathrm{ft}^{3} / \mathrm{s}$. The large difference in inflow to the Delaware River between Barryville and Port Jervis during the August 1955 flood and the June 2006 flood is mostly attributable to precipitation and runoff amounts and patterns but is also partly attributable to the effects of Prompton Reservoir, General Edgar Jadwin Reservoir, and Lake Wallenpaupack on flood flows in the Lackawaxen River basin. Discharge hydrographs for the August 1955 and June 2006 floods at selected sites along the main stem of the Delaware River are shown in figure 10B.

Upstream from the confluence of the East and West Branches of the Delaware River in Hancock, recorded peak flows during the January 1996, September 2004, and April 2005 floods exceeded the August 1955 flood at several USGS stream-gaging stations (table $4 \mathrm{~b}$ ). The Pepacton Reservoir is along the East Branch of the Delaware River just upstream from Downsville. The Pepacton Reservoir began storage operations on September 15, 1954. During the August 1955 flood, the USGS stream-gaging station East Branch Delaware River at Margaretville (01413500), upstream from the Pepacton Reservoir, recorded a peak discharge of 9,990 ft $3 / \mathrm{s}$ flowing into the reservoir. The Pepacton Reservoir, which was at 39 percent of capacity on August 1, 1955, stored all the runoff from the upstream contributing drainage area and as a result, the peak discharge recorded at the USGS streamgaging station East Branch Delaware River at Downsville (01417000), immediately downstream from the Pepacton Reservoir, was only $620 \mathrm{ft}^{3} / \mathrm{s}$ during the August 1955 flood. On September 1, 1955, the water-level in the Pepacton Reservoir had reached and elevation of about 1,159.6 ft (fig. 11), and was at just over 50 percent of capacity after storing runoff from the back-to-back hurricanes that struck the region from August 11 to 20, 1955 (Bogart, 1960) During the January 1996 flood the water level in the Pepacton Reservoir rose nearly $20 \mathrm{ft}$ with an estimated inflow of greater than $50,000 \mathrm{ft}^{3} / \mathrm{s}$. On June 28, 2006, the water level in the Pepacton Reservoir reached a new period-of-record maximum elevation of 1,283.74 ft Prior to the construction of the Pepacton Reservoir, the period-of-record maximum discharge at USGS streamgaging station East Branch Delaware River at Downsville was $23,900 \mathrm{ft}^{3} / \mathrm{s}$, recorded on November 26, 1950. Farther downstream at the USGS stream-gaging station East Branch Delaware River at Fishs Eddy (01421000), a peak discharge of $27,400 \mathrm{ft}^{3} / \mathrm{s}$ was recorded during the August 1955 flood. 


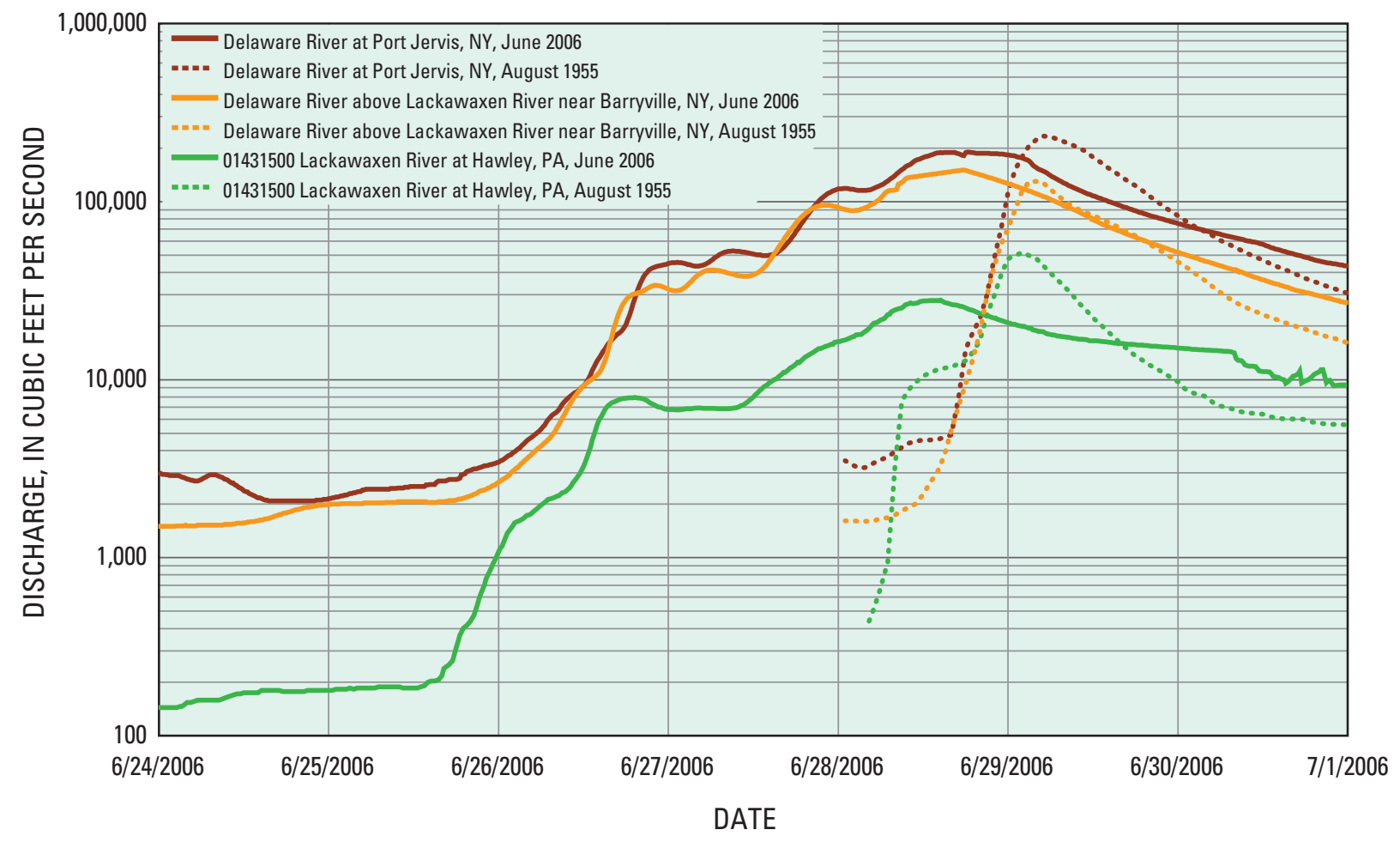

Figure 10B. Discharge hydrographs for selected stream-gaging stations in the Delaware River basin, NY, for the June 2006 and August 1955 floods. (Locations shown in fig. 4B.)

Subsequent to the flood of August 1955, the floods of September 2004 and April 2005 were close in magnitude along the East Branch of the Delaware River from Downsville to Fishs Eddy. Peak discharges of 20,200 and 19,400 ft 3 s were recorded at the Downsville stream-gaging station during the floods of 2004 and 2005, respectively, and 56,300 and 65,100 $\mathrm{ft}^{3} / \mathrm{s}$ were recorded at the Fishs Eddy stream-gaging station during the floods of 2004 and 2005, respectively. The recorded peak discharge for the June 2006 flood, 77,400 ft $3 / \mathrm{s}$, was a new period-of-record maximum for the USGS stream-gaging station East Branch Delaware River at Fishs Eddy since the stream-gaging station was put into operation in October 1912 ( fig. 7B-5).

Along the West Branch of the Delaware River, the August 1955 flood produced peak discharges of 15,100 $\mathrm{ft}^{3} / \mathrm{s}$ at the Walton stream-gaging station (01423000) and $16,000 \mathrm{ft}^{3} / \mathrm{s}$ downstream at the Hale Eddy stream-gaging station (01426500). The Cannonsville Reservoir was constructed and began operations on September 30, 1963. Prior to the June 2006 flood, the period-of-record maximum discharge at the USGS stream-gaging station West Branch Delaware River at Walton was $25,000 \mathrm{ft}^{3} / \mathrm{s}$ recorded on January 19, 1996. The Cannonsville Reservoir was at 65 percent of capacity prior to the January 1996 flood. The peak inflow to the Cannonsville Reservoir was computed to be about 35,000 $\mathrm{ft}^{3} / \mathrm{s}$ on January 19, 1996 (Lumia, 1998). The peak discharge recorded at the USGS stream-gaging station West Branch Delaware River at Stilesville (01425000), about 1.8 mi downstream from the Cannonsville Reservoir, during the January 1996 flood was $112 \mathrm{ft}^{3} / \mathrm{s}$. The water level in the reservoir rose nearly $23 \mathrm{ft}$ from January 18 to $23,4.0 \mathrm{in}$. of runoff was stored during this period, and the reservoir began to spill on January 25. The Catskill Mountain part of the New York City reservoir system (includes all six New York City reservoirs in the Catskill Mountians) stored about 95.5 billion gallons of floodwaters during January 18-23, 1996 (Lumia, 1998). Peak discharges of 15,200 and $17,500 \mathrm{ft}^{3} / \mathrm{s}$ were recorded at the Walton and Hale Eddy stream-gaging stations during the flood of September 2004. Peak discharges of 18,400 and 21,500 $\mathrm{ft}^{3} / \mathrm{s}$ were recorded at the Walton and Hale Eddy stream-gaging stations during the flood of April 2005, whereas period-of-record peak discharges of 28,600 and $43,400 \mathrm{ft}^{3} / \mathrm{s}$ were recorded during the flood of June 2006 (figs. 7B-6, 7B-8).

The June 2006 flood is the greatest flood since the flood of October 1903 along the lower reach of the East Branch Delaware River from East Branch to Hancock, along the middle and lower reaches of the West Branch Delaware River from Walton to Hancock, and along the main stem Delaware River from Hancock to the confluence with the Lackawaxen River. 


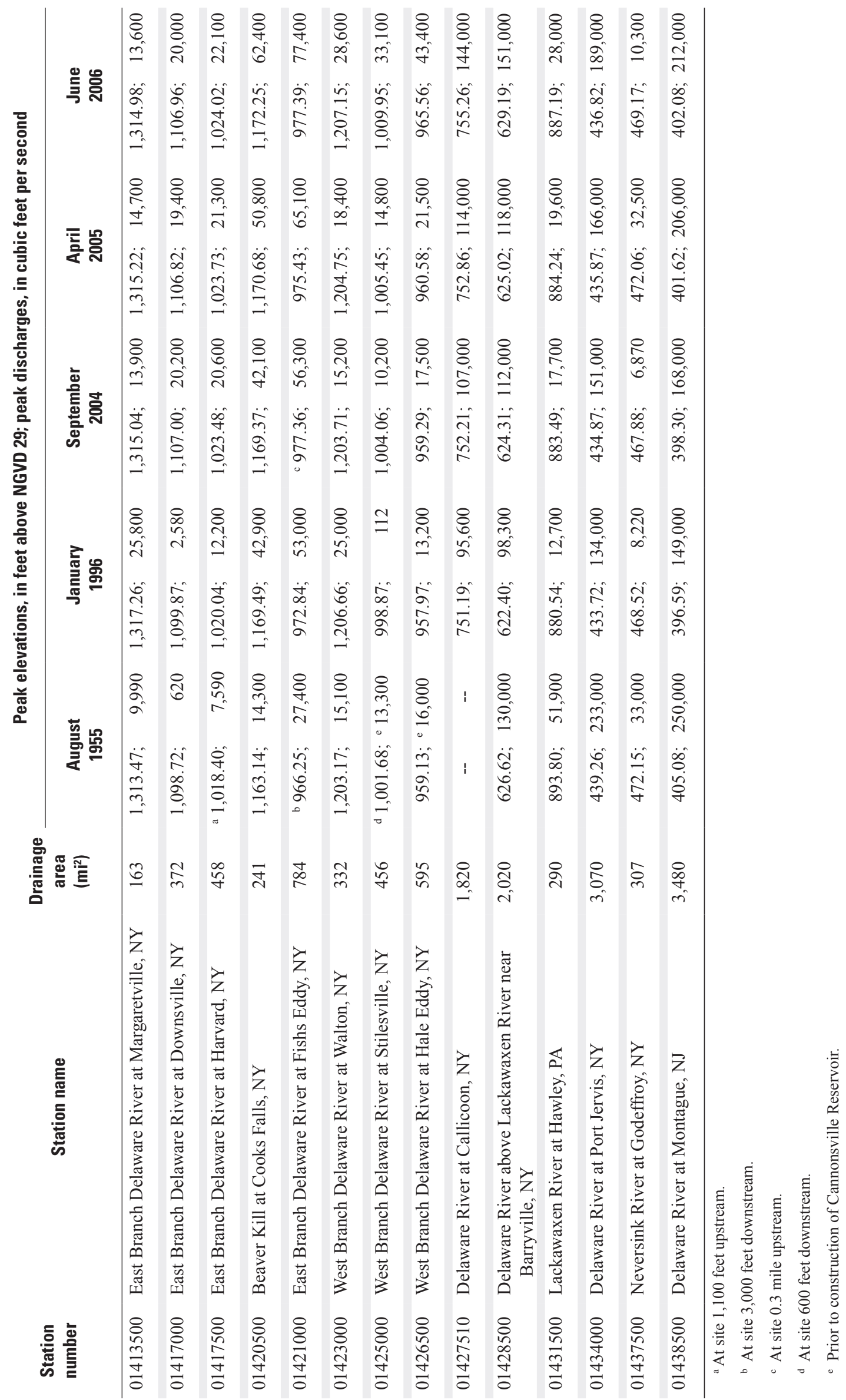




\section{Susquehanna River Basin}

In the Susquehanna River basin, peak discharges from the June 2006 flood were compared to historic peaks from the floods of March 1936, June 1972, and April 2005 at selected USGS stream-gaging stations (table 4C). At the time, the March 1936 flood was the greatest flood of record in the upper reaches of the Susquehanna River basin (upstream from Waverly, NY), except for part of the Chemung River basin that was hit even harder by the flood of July 1935 (Grover, 1937). The June 1972 flood that resulted from heavy rains brought on by remnants of Hurricane Agnes produced record flooding along the Chemung River and throughout the Susquehanna River basin downstream from Waverly. Hurricane Agnes delivered more than 19 in. of rain from June 19-24, 1972, as it moved from the Gulf of Mexico across Florida, then up the east coast through New York, into Canada, and finally out to sea. Although many long-standing flood records were exceeded in six states and 122 people were killed as a result of this storm (National Oceanic and Atmospheric Administration, 2002), peak discharges recorded during the July 1935 and March 1936 floods remained greater than those of the June 1972 storm at many locations upstream from Waverly, along the Susquehanna, Chenango, and Tioughnioga Rivers. Discharge hydrographs for selected USGS stream-gaging stations in the Susquehanna River basin for the March 1936, June 1972, and June 2006 floods are shown in figure 10C. The peak discharge at the USGS streamgaging station Susquehanna River at Unadilla (01500500) was estimated to be about 31,300 ft $\mathrm{ft}^{3} / \mathrm{s}$ during the March 1936 flood. Peak discharges recorded along the Chenango River at the Sherburne (01505000) and Chenango Forks (01512500) stream-gaging stations were 12,500 (estimated) and $50,100 \mathrm{ft}^{3} / \mathrm{s}$, respectively (table $4 \mathrm{C}$ ). The USGS stream-gaging stations on the Susquehanna River at Conkin (01503000) and at Vestal (01513500) recorded peak discharges of 61,600 and $107,000 \mathrm{ft}^{3} / \mathrm{s}$ (estimated), respectively, during the March $1936 \mathrm{flood}$, and 26,500 and 50,400 ft 3 /s, respectively, during the June 1972 flood (figs. 7C-3, 7C-8). Several new period-of-record maximum discharges were recorded in the Susuquehanna River basin as a result of the June 2006 flood. The USGS stream-gaging stations Susquehanna River at Unadilla, at Conklin, and at Vestal recorded new periodof-record maximum discharges of $35,100 \mathrm{ft}^{3} / \mathrm{s}, 76,800$, and 119,000 respectively, during the June 2006 flood. The Susquehanna River near Waverly, NY(01515000), streamgaging station is $1 \mathrm{mi}$ downstream from the New YorkPennsylvania state line and has been in operation since February 1937. An estimated peak discharge, outside the period of record, of $128,000 \mathrm{ft}^{3} / \mathrm{s}$ was determined from flood profiles for the March 1936 flood. Coincidentally, a peak discharge of $128,000 \mathrm{ft}^{3} / \mathrm{s}$ was recorded on June 28,2006 , and is considered the new period-of-record maximum for the Susquehanna River near Waverly stream-gaging station.

\section{Peak Water-Surface Elevations at Flood Study Sites}

Measurements of peak water-surface elevations were made at 104 sites along the Mohawk, Delaware, and Susquehanna Rivers. The study area in the Mohawk River basin includes study sites on the West and East Canada Creeks and along the Mohawk River from below Delta Dam near Rome east to Erie Canal Lock 9 at Rotterdam Junction (fig. 12A).

In the Delaware River basin, study sites were identified on tributaries to the East Branch Delaware River, which included the Little Beaver Kill, Willowemoc Creek, and Beaver Kill. Study sites also were selected along the East Branch Delaware River from Harvard to the confluence of the East and West Branches of the Delaware River near Hancock. Along the West Branch Delaware River, study sites were selected at points upstream from the Cannonsville Reservoir near Delhi to the confluence of the East and West Branches of the Delaware River below the Cannonsville Reservoir near Hancock. Study sites were not selected upstream from the Pepacton Reservoir along the East Branch Delaware River because several USGS stream-gaging stations in this area generally indicated peak discharges had recurrence intervals of 15 years or less. Study sites also were selected along the main stem of the Delaware River from Hancock to Port Jervis and along Callicoon Creek, a tributary to the Delaware River (fig. 12B).

In the Susquehanna River basin, study sites were selected along the Susquehanna River from Cooperstown, NY, downstream to Athens, PA. Sites also were selected along tributaries to the Susquehanna River, which included the Unadilla, the Tioughnioga, and the Chenango Rivers. Although these areas were devastated by floods in the past, major flooding was not identified during June 27-29, 2006, along the Chemung River; therefore, study sites were not selected along this major tributary to the Susquehanna River (fig. 12C).

High-water marks at each site were flagged and surveyed to obtain peak water-surface elevations, and were referenced to the National Geodetic Vertical Datum of 1929 (NGVD 29). A data correction value used to convert elevations from NGVD 29 to North American Vertical Datum of 1988 (NAVD 88) at each site was calculated by using the National Geodetic Survey (NGS) North American Vertical Datum Conversion (VERTCON) Utility (National Oceanic and Atmospheric Administration, 2006d). At sites associated with a bridge, high-water marks were obtained upstream and downstream from the structure when possible.

The accuracy of high-water marks was rated subjectively by field personnel as "excellent," "good," "fair," or "poor," according to the guidelines of Benson and Dalrymple (1967). "Excellent" means the reported high-water mark is considered within $0.02 \mathrm{ft}$ of the true high-water elevation, "good" within $0.05 \mathrm{ft}$ and "fair" within $0.10 \mathrm{ft}$; "poor" implies less than "fair" 

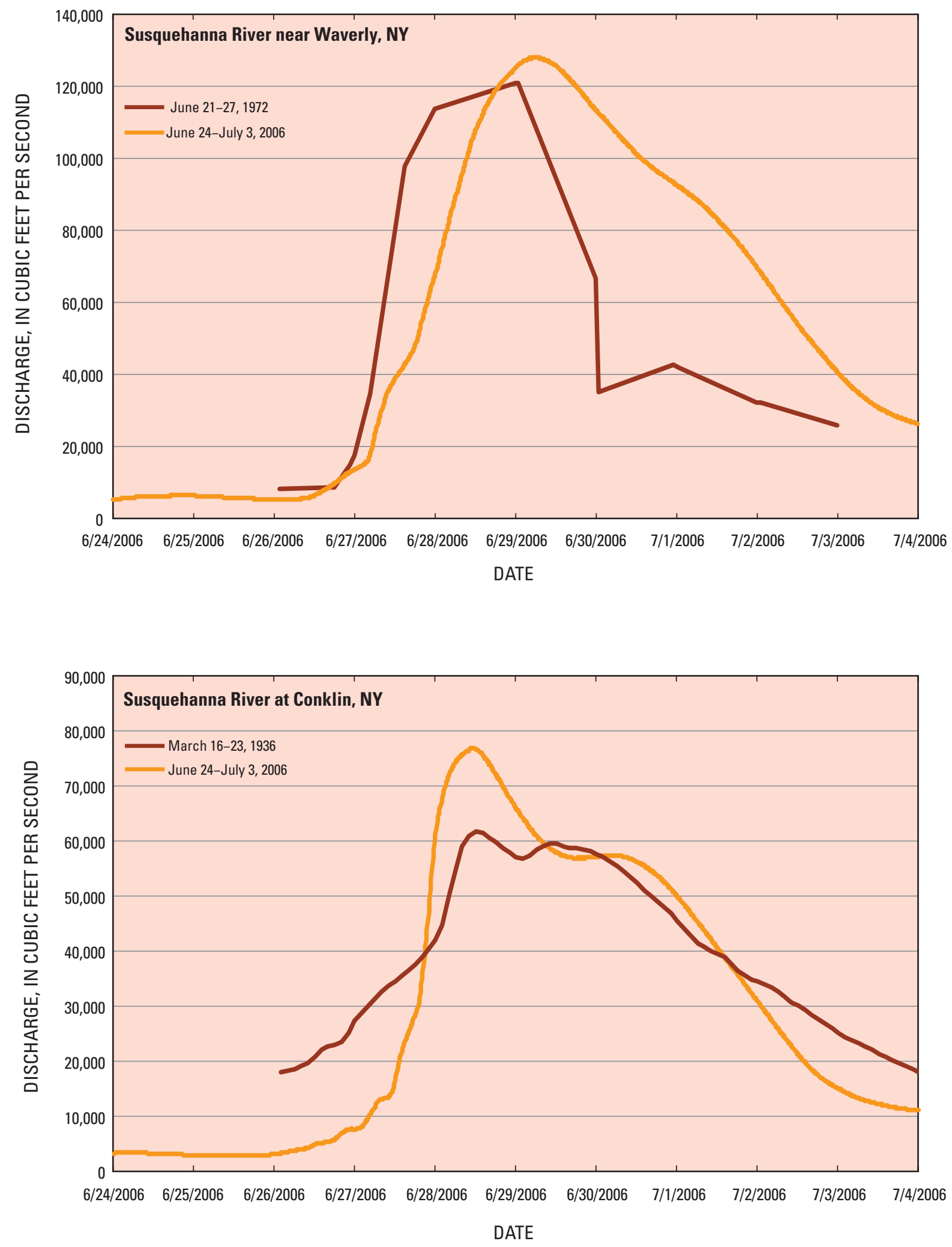

Figure 10C. Discharge hydrographs for selected historic floods at (1) the Susquehanna River near Waverly, NY, and (2) the Susquehanna River at Conklin, NY, stream-gaging stations. (Locations shown in fig. 4C.) 


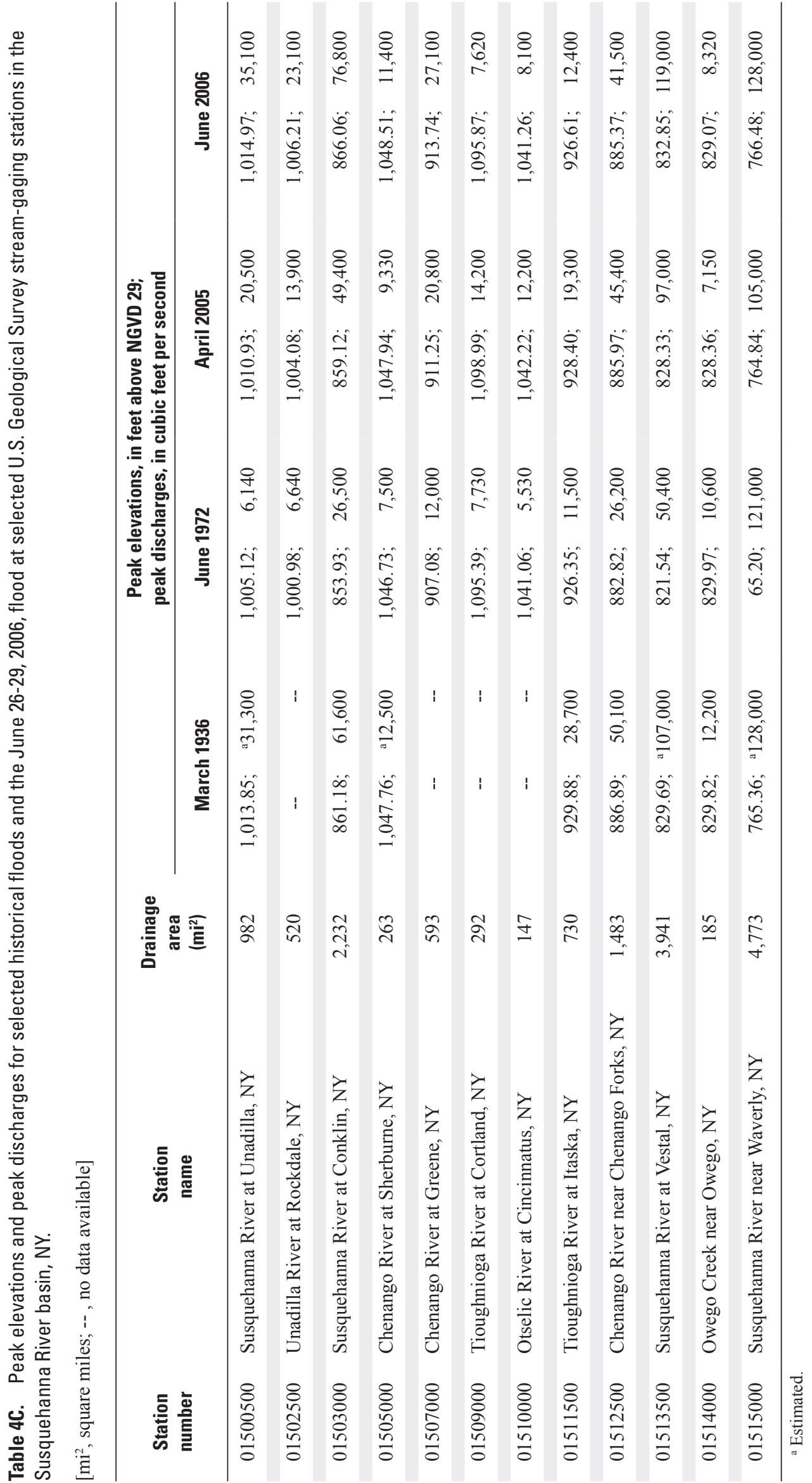



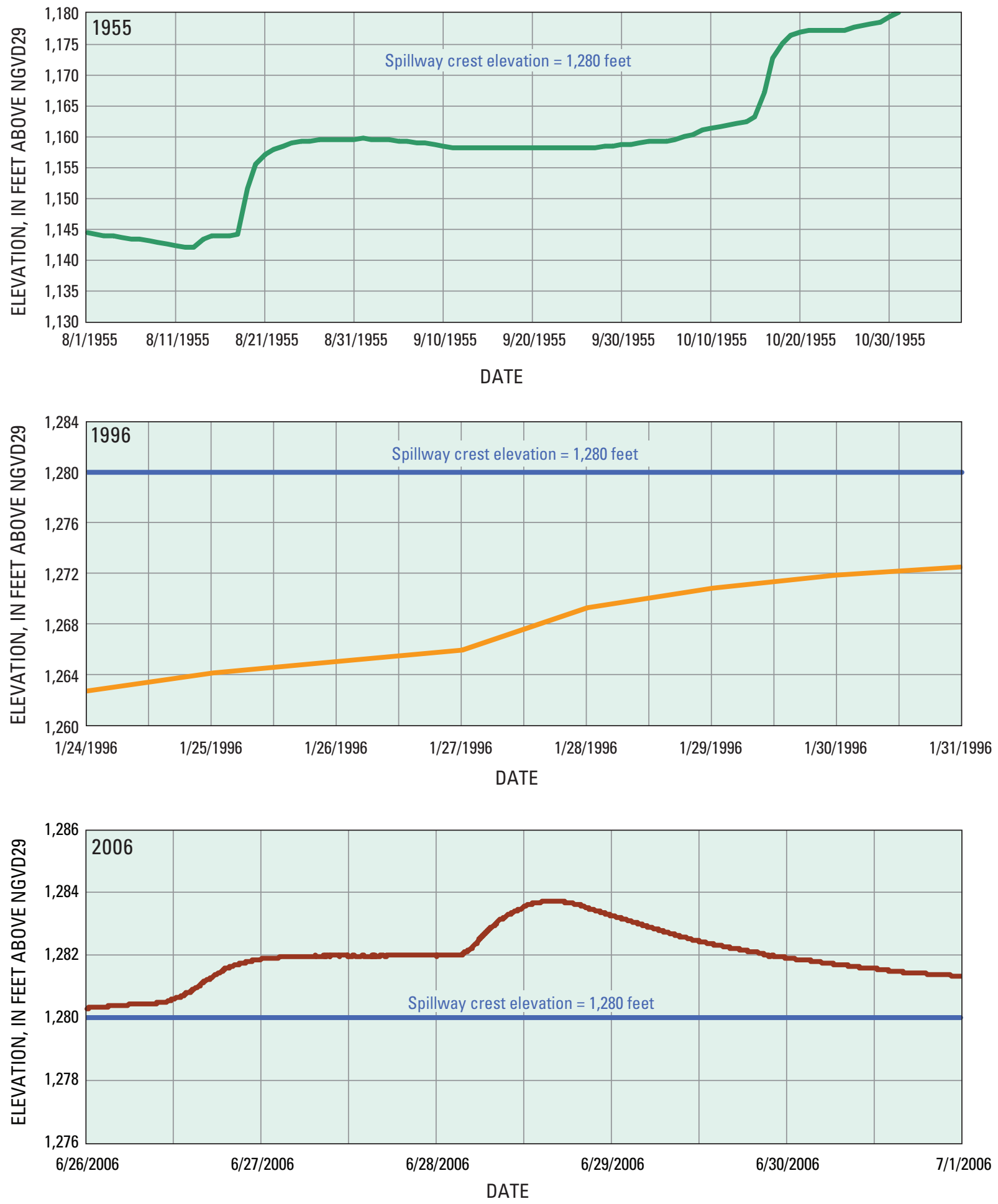

Figure 11. Water-surface elevation in the Pepacton Reservoir, NY, during August-October 1955, January 1996, and June 2006. 


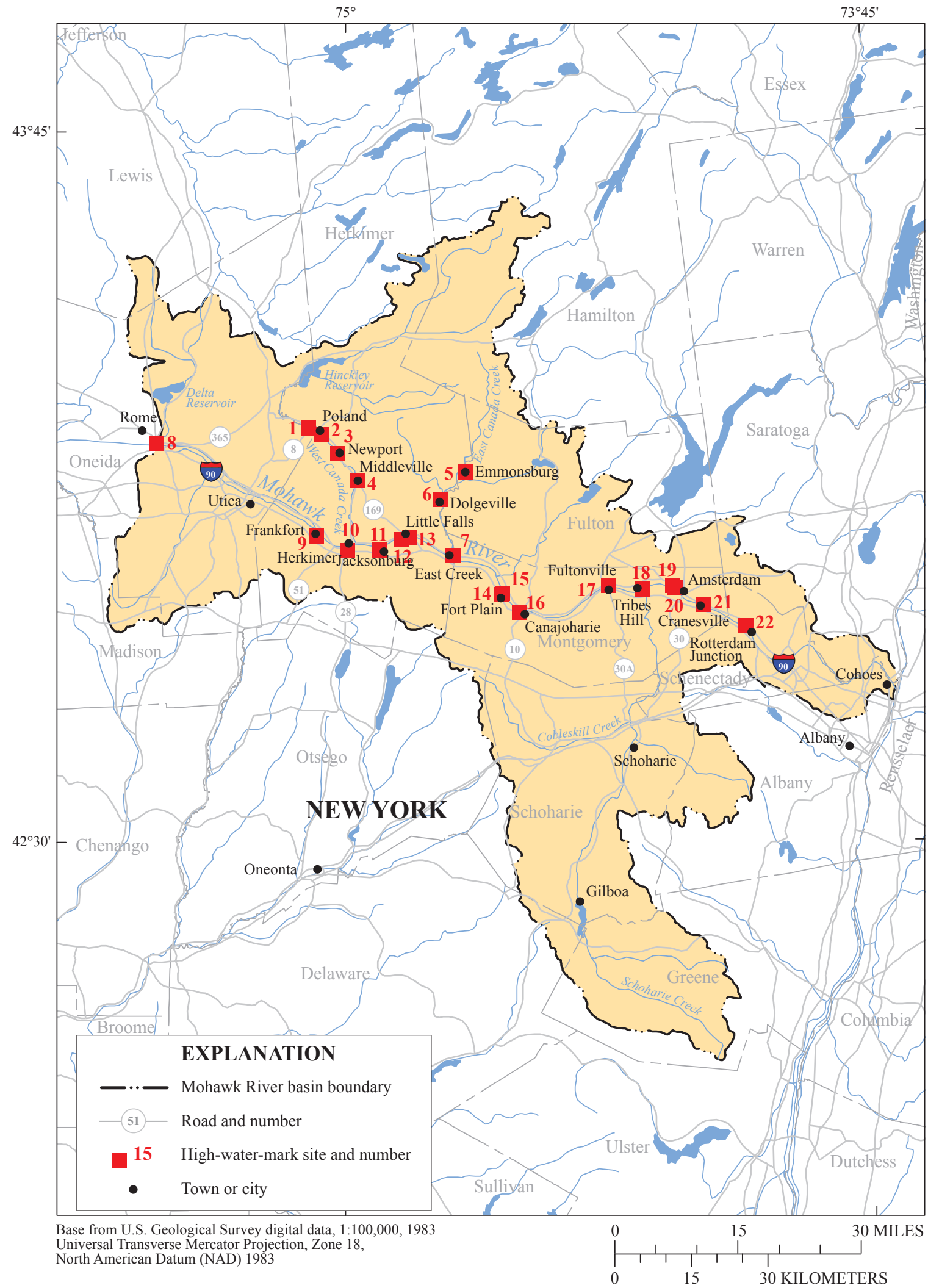

Figure 12A. Locations of 22 high-water-mark sites chosen for study in the Mohawk River basin, NY, for the flood of June $26-29,2006$. (Site numbers and flood data listed in table 5A.) 


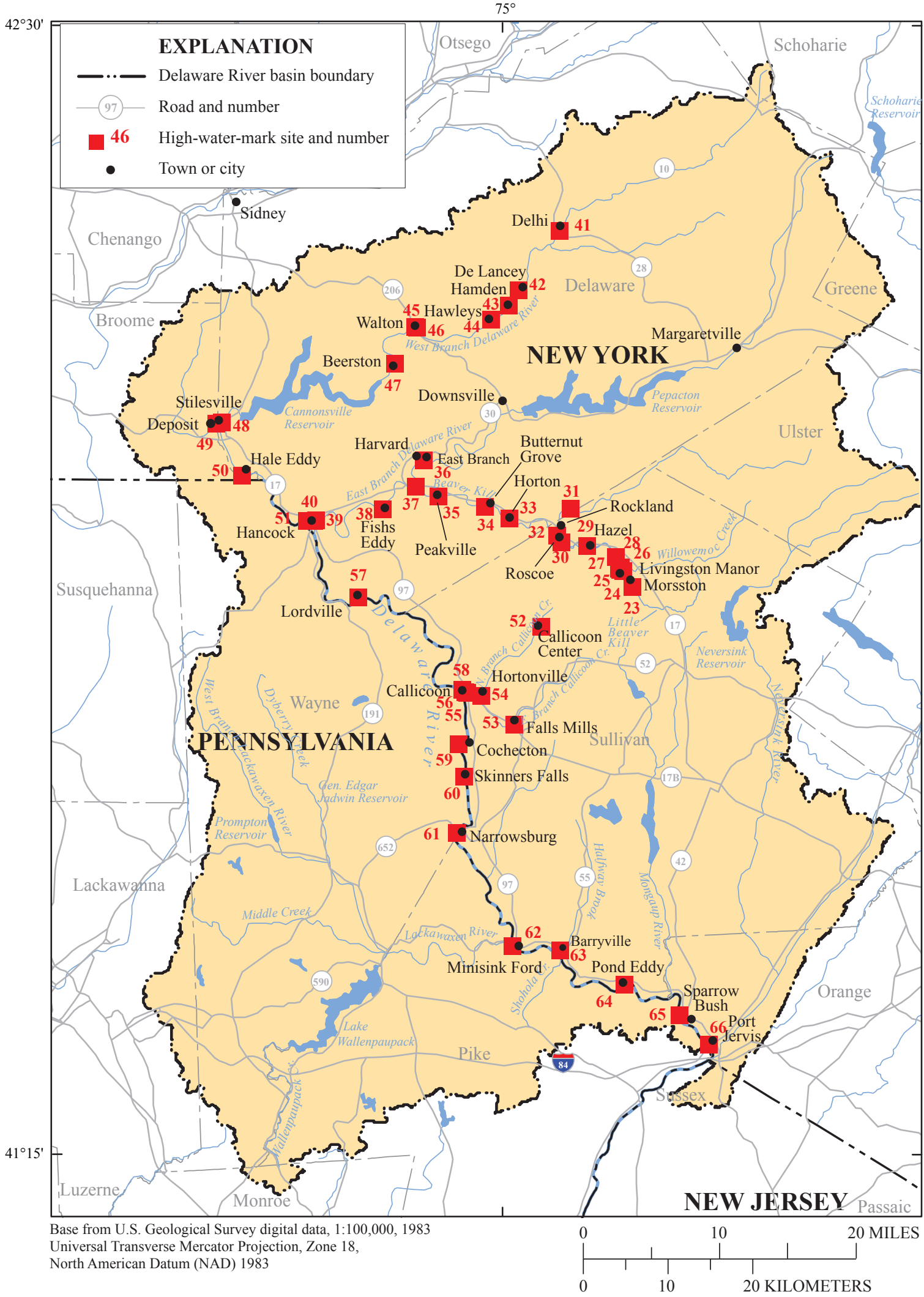

Figure 12B. Locations of 44 high-water-mark sites chosen for study in the Delaware River basin, NY, for the flood of June $26-29,2006$. (Site numbers and flood data listed in table 5B.) 


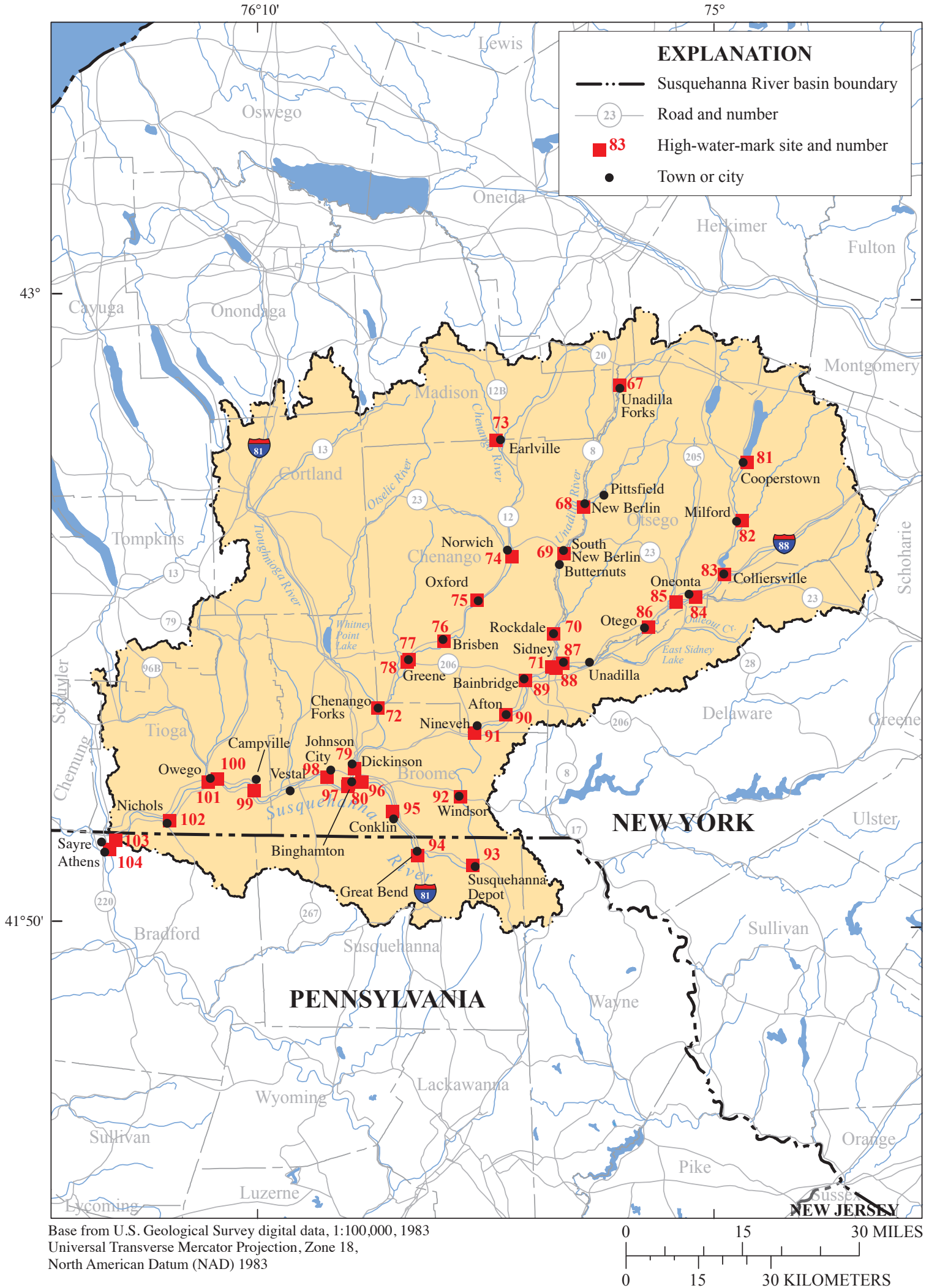

Figure 12C. Locations of 38 high-water-mark sites chosen for study in the Susquehanna River basin, NY, for the flood of June 26-29, 2006. (Site numbers and flood data listed in table 5C.) 
accuracy. The high-water-mark description, photographs, location (latitude and longitude), and location with respect to a nearby bridge or other structure were documented and are presented in appendix 1. High-water-mark locations described as "left bank" or "right bank" are in relation to an observer facing downstream.

Peak water-surface elevations for the June 2006 flood were compared with flood-profile elevations published in FEMA flood-insurance studies (Federal Emergency Management Agency; 1976a-c, 1977, 1978a-b, 1979a-c, 1980a-b, 1981a-d, 1982a-f, 1983a-b, 1984a-b, 1985, 1986a-b, 1987a-g, 1988, 1990a-b, 1991a-b, 1992a-c, 1993a-c, 1997, 1998a-b, 1999a-c, 2000, 2001a-b, 2002a-d). Peak water-surface elevations and published FEMA 10-, 50-, $100-$, and 500-year flood elevations are compiled in table 5. Flood elevations at 10-, 50-, 100-, and 500-year recurrence intervals and those determined for the flood of June 26-29, 2006, for selected sites in the Mohawk, Delaware, and Susquehanna River basins are plotted in figure 13.

FEMA flood-insurance studies are not available for all the communities studied along the West Canada Creek. The 100-year elevation was available for the communities of Poland and Newport (sites 1-3). The peak water-surface elevations for sites 1 and 2 were above the 100 -year floodprofile elevation, and the peak water-surface elevation at site 3 was just below the 100 -year flood-profile elevation. A FEMA flood-insurance study is available for the community of Dolgeville (site 6) along the East Canada Creek. Peak water-surface elevations upstream from State Route 29 in Dolgeville were between the 50- and 100-year flood-profile elevations, and the peak water-surface elevation downstream from the Route 29 bridge was between the 100- and 500-year flood-profile elevations. FEMA flood-insurance studies were available for most of the communities along the Mohawk River from Rome (site 8) to Rotterdam Junction (site 22). Peak water-surface elevations from Rome to Little Falls (site 12) were at or below the 10-year flood-profile elevation. Peak water-surface elevations at Lock 17 in Little Falls (site 13) and at Fort Plain (site 15) were generally between the 100- and 500-year flood-profile elevations, but peak water-surface elevations at Lock 15 at Fort Plain (site 14), at Canajoharie (site 16), and at Fonda/Fultonville (site 17) were all higher than the 500-year flood-profile elevations. Peak water-surface elevations from Amsterdam (site 19) to Rotterdam Junction (site 22) were generally between the 10- and 50-year flood-profile elevations.

FEMA flood-insurance studies were available for most study sites along the Little Beaver Kill, the Willowemoc, and the Beaver Kill. Peak water-surface elevations along the Little Beaver Kill from Morriston (site 23) to Livingston Manor (site 25) were generally at the 500-year flood-profile elevations. Along the Willowemoc Creek from its confluence with the Little Beaver Kill in Livingston Manor (site 27) downstream to Roscoe ( site 30), the peak water-surface elevations range from higher than the 500-year flood profile down to about equal to or just below the 50 -year flood-profile elevations, respectively. There were only limited FEMA flood-insurance studies available along the Beaver Kill from Rockland (site 31) to Peakville (site 35). Peak water-surface elevations range from slightly lower than the 100 -year floodprofile elevation in the upper reach to slightly higher than the 50-year flood-profile elevation at Peakville.

Peak water-surface elevations were compared to FEMA flood-insurance study elevations for sites along the East Branch Delaware River (fig. 12b) below the Pepacton Reservoir in Harvard (site 36) to the confluence with the West Branch Delaware River in Hancock (site 40). Peak water-surface elevations were at the 10-year flood-profile elevation in Harvard and at East Branch (site 37) but generally increased to about the 50-year flood-profile elevations, from Fishs Eddy (site 38) to Hancock. FEMA flood-insurance studies are not available for all study sites along the West Branch Delaware River. Peak water-surface elevations were between the 10- and 50-year flood-profile elevations in the community of Delhi (site 41) and generally at the 100-year flood-profile elevation in the community of Walton (sites 45 and 46). Downstream from the Cannonsville Reservoir from Deposit (site 48) to Hale Eddy (site 50), the peak watersurface elevations were higher than the 500-year flood-profile elevations, and at Hancock (site 51) were at the 100-year profile. FEMA flood-insurance studies are not available for all study sites along Callicoon Creek. Along Callicoon Creek from Hortonville (site 54) to Callicoon (site 56), the peak water-surface elevations were between the 100- and 500-year flood-profile elevations. Along the main stem of the Delaware River from Lordville (site 57) to Port Jervis (site 66), the peak water-surface elevations were generally between the 100- and 500 -year flood-profile elevations. Comparisons of peak watersurface elevations at selected study sites in the Delaware River basin between the September 2004 and the June 2006 floods are shown in appendix 2.

FEMA flood-insurance studies were only available for limited study sites along the Unadilla and Tioughnioga Rivers. Peak water-surface elevations along the Unadilla River at Rockdale (site70) and near Unadilla (site 71) were higher than the 500-year flood-profile elevations. Along the Tioughnioga River at the USGS stream-gaging station at Cortland (01509000), the peak water-surface elevation was slightly lower than the 10-year flood-profile elevation and $2.8 \mathrm{ft}$ lower than the 100-year flood-profile elevation; at Chenango Forks (site 72), the peak water-surface elevation is $3.3 \mathrm{ft}$ lower than the 100-year flood-profile elevation (100-year flood profile was the only available profile in this area). FEMA floodinsurance studies were available for most study sites along the Chenango River. The Chenango River is a major tributary that joins the Susquehanna River in the City of Binghamton. The peak discharge at the Chenango River at Sherburne streamgaging station (01505000) had a recurrence interval of about 60 years. The peak water-surface elevation at the Chenango River at Route 32A in Norwich (site74) was between the 10- and 50-year flood-profile elevations. Downstream at Brisben (site 76), the peak water-surface elevation was 

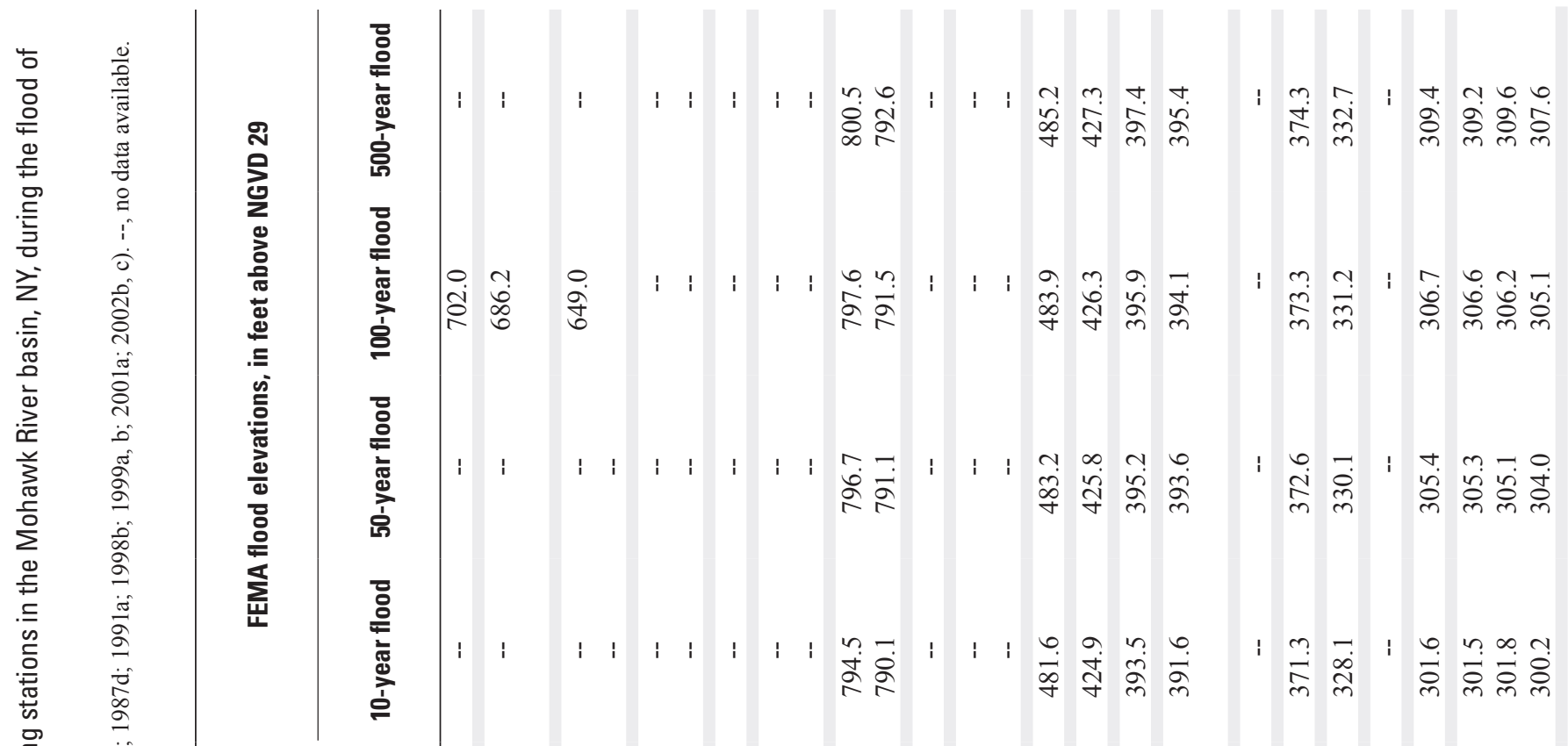

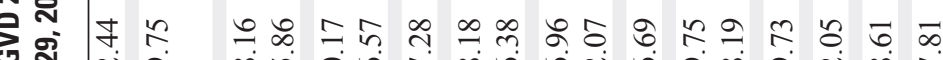
ॠ
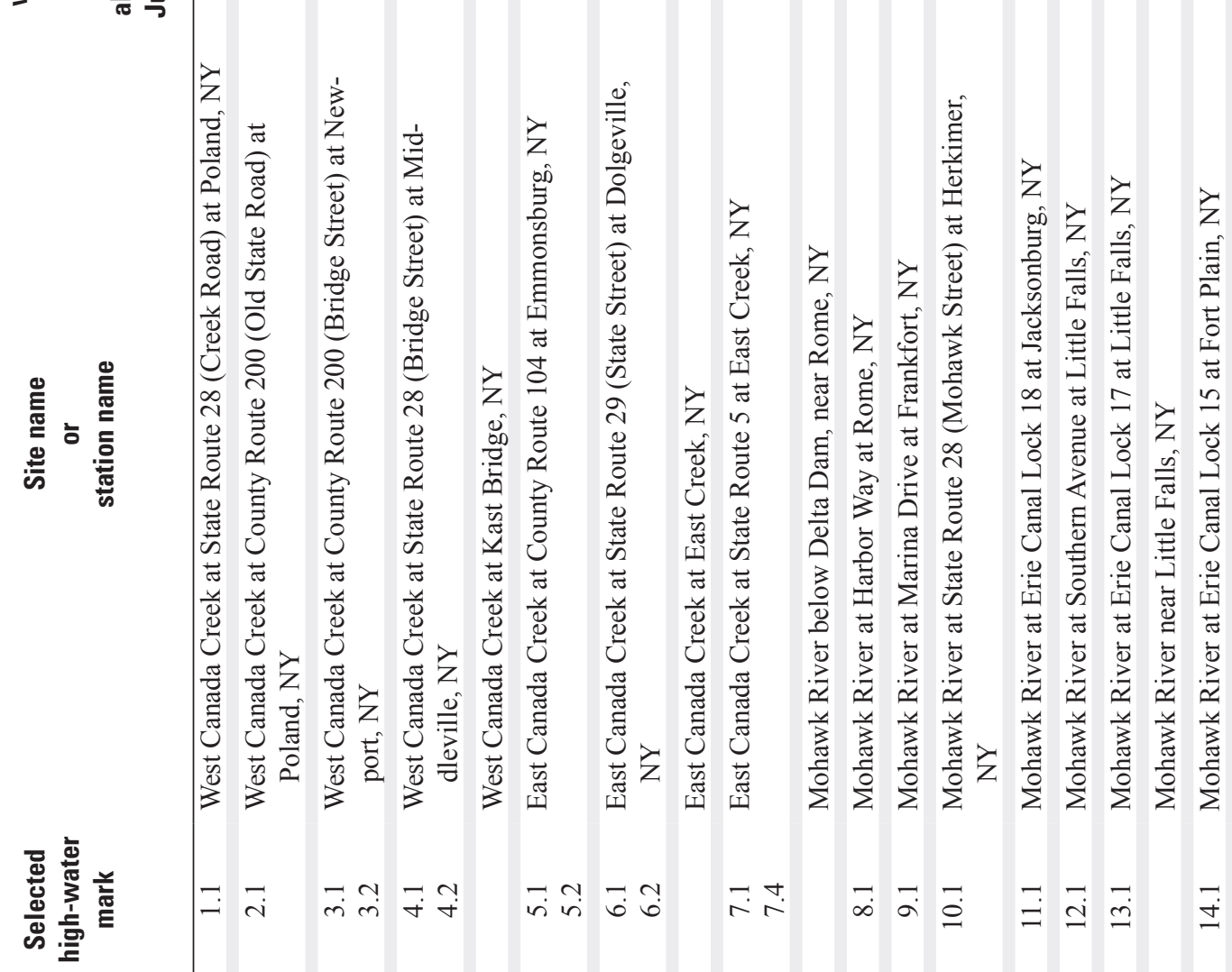

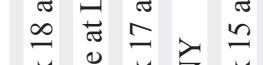

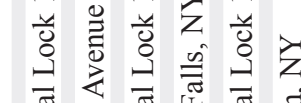

ส

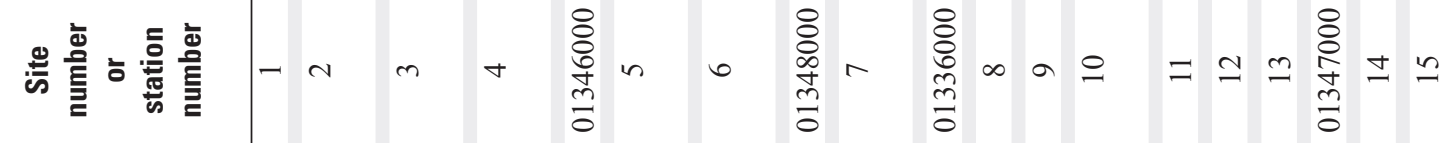




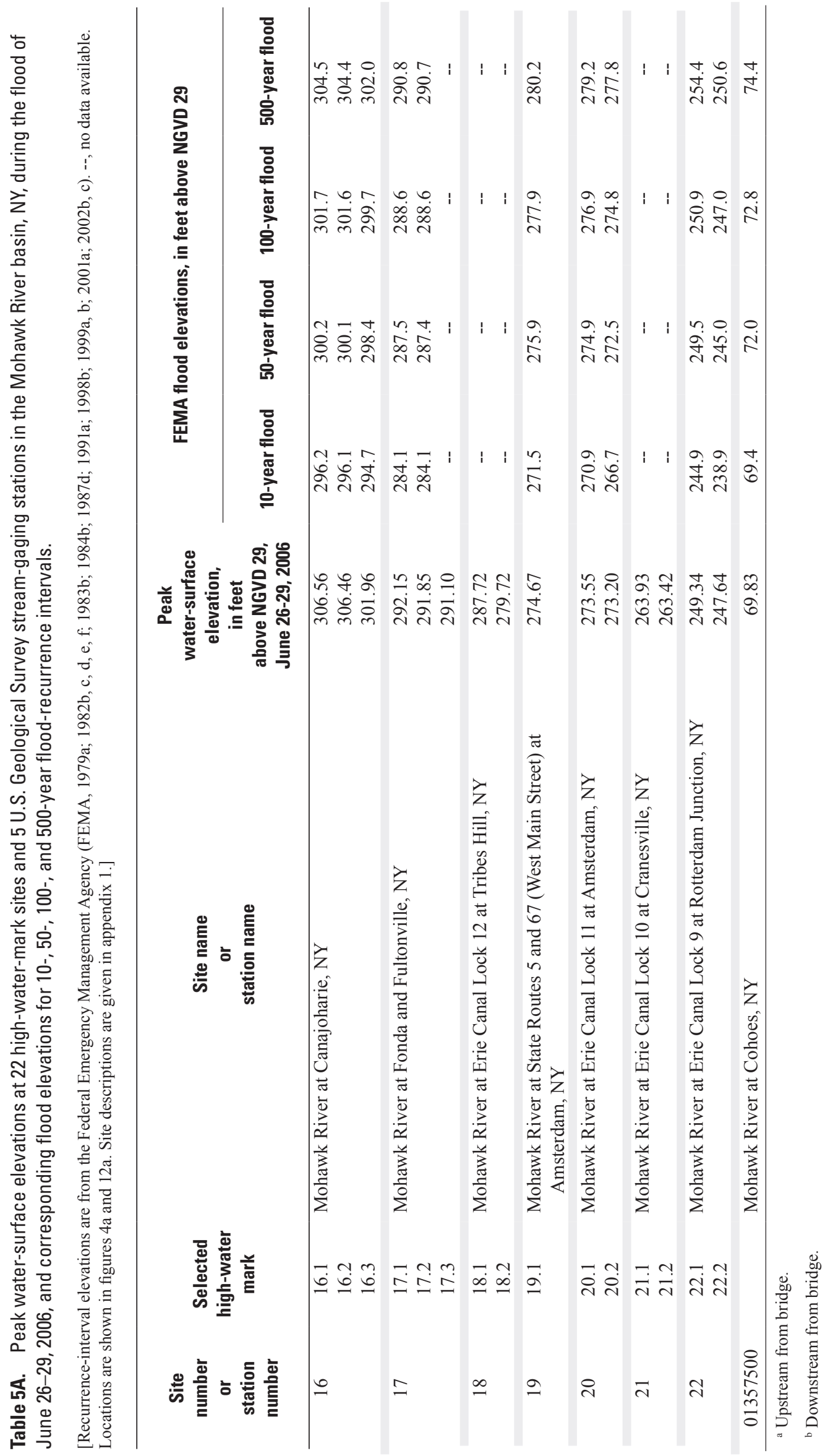




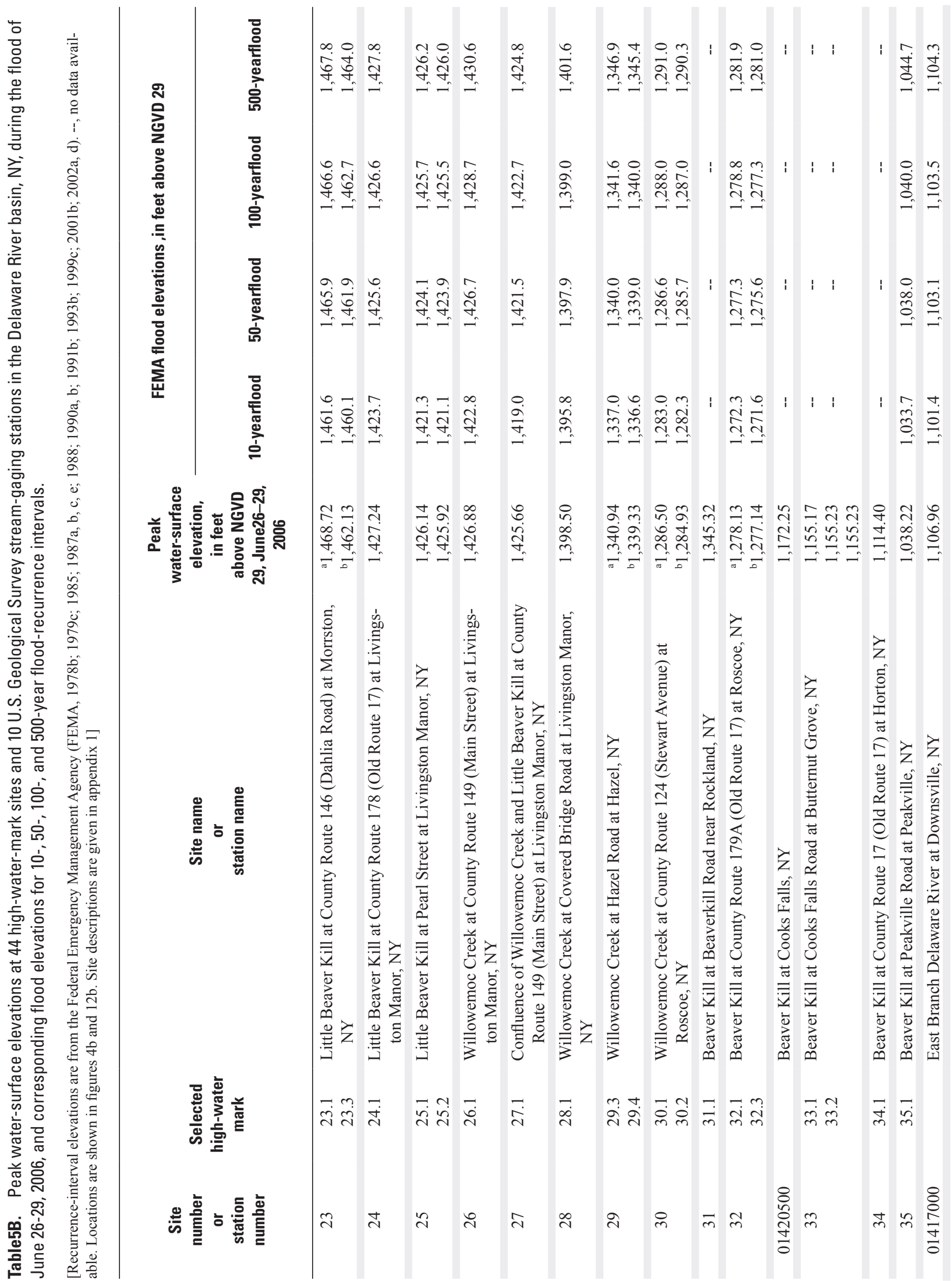




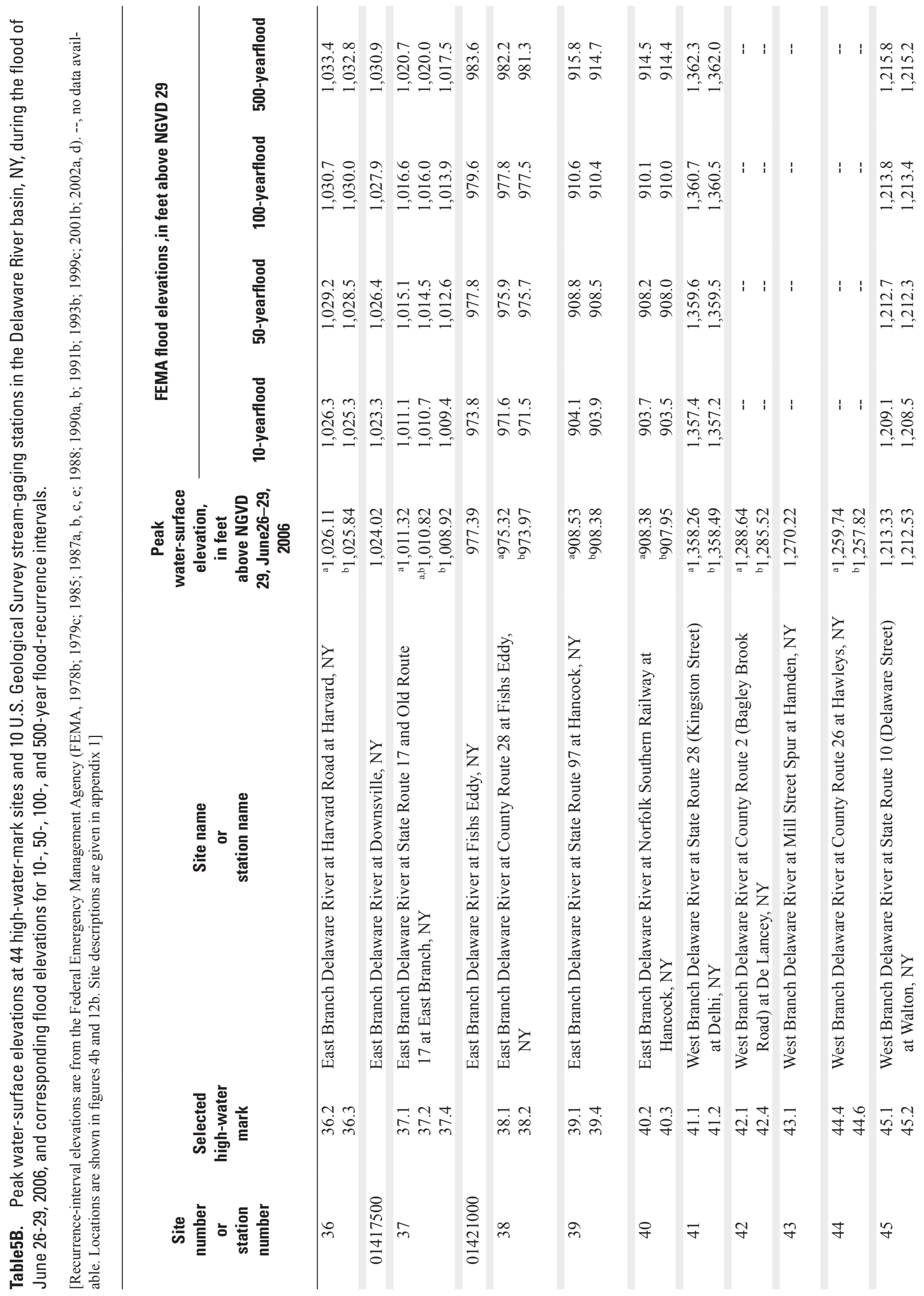




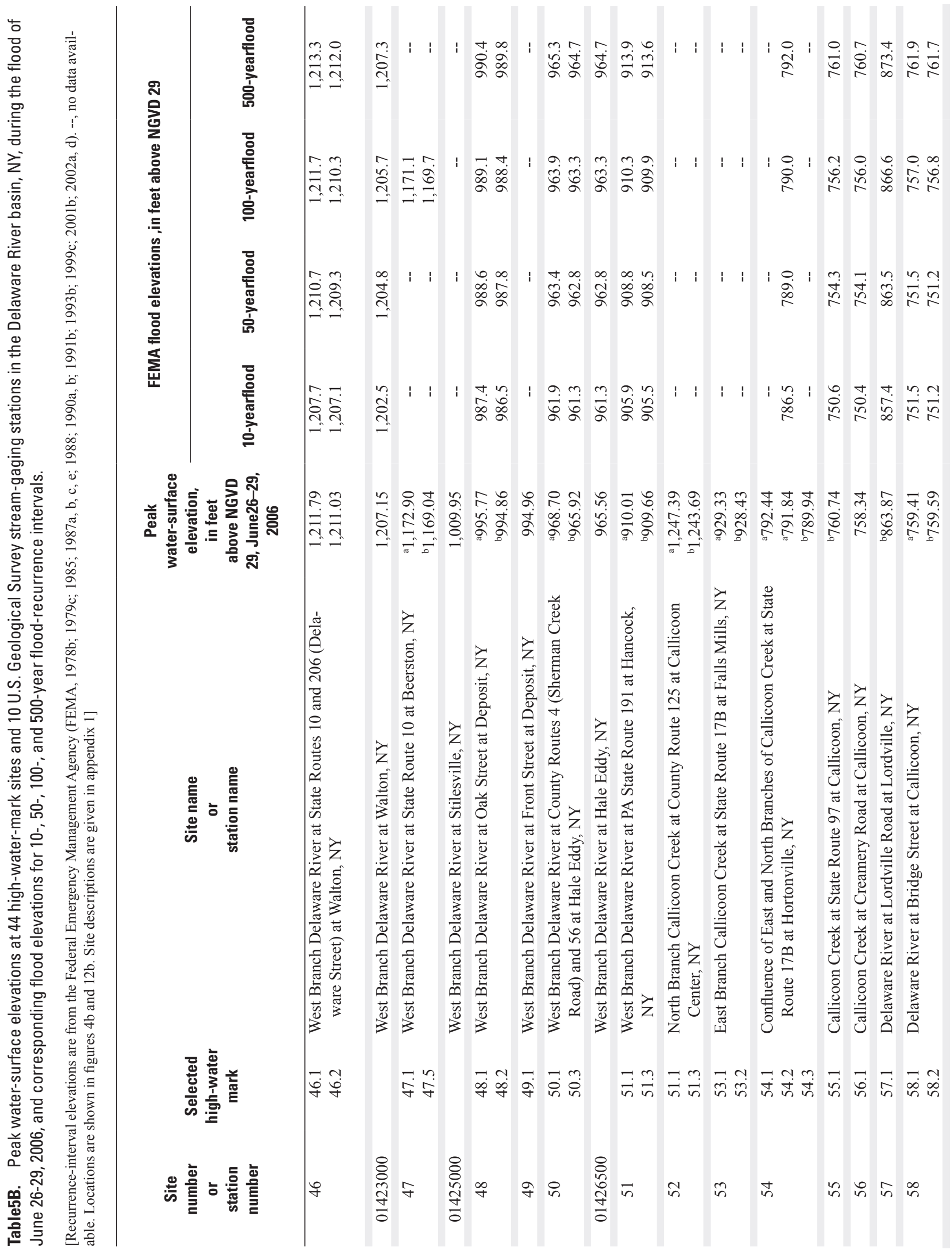




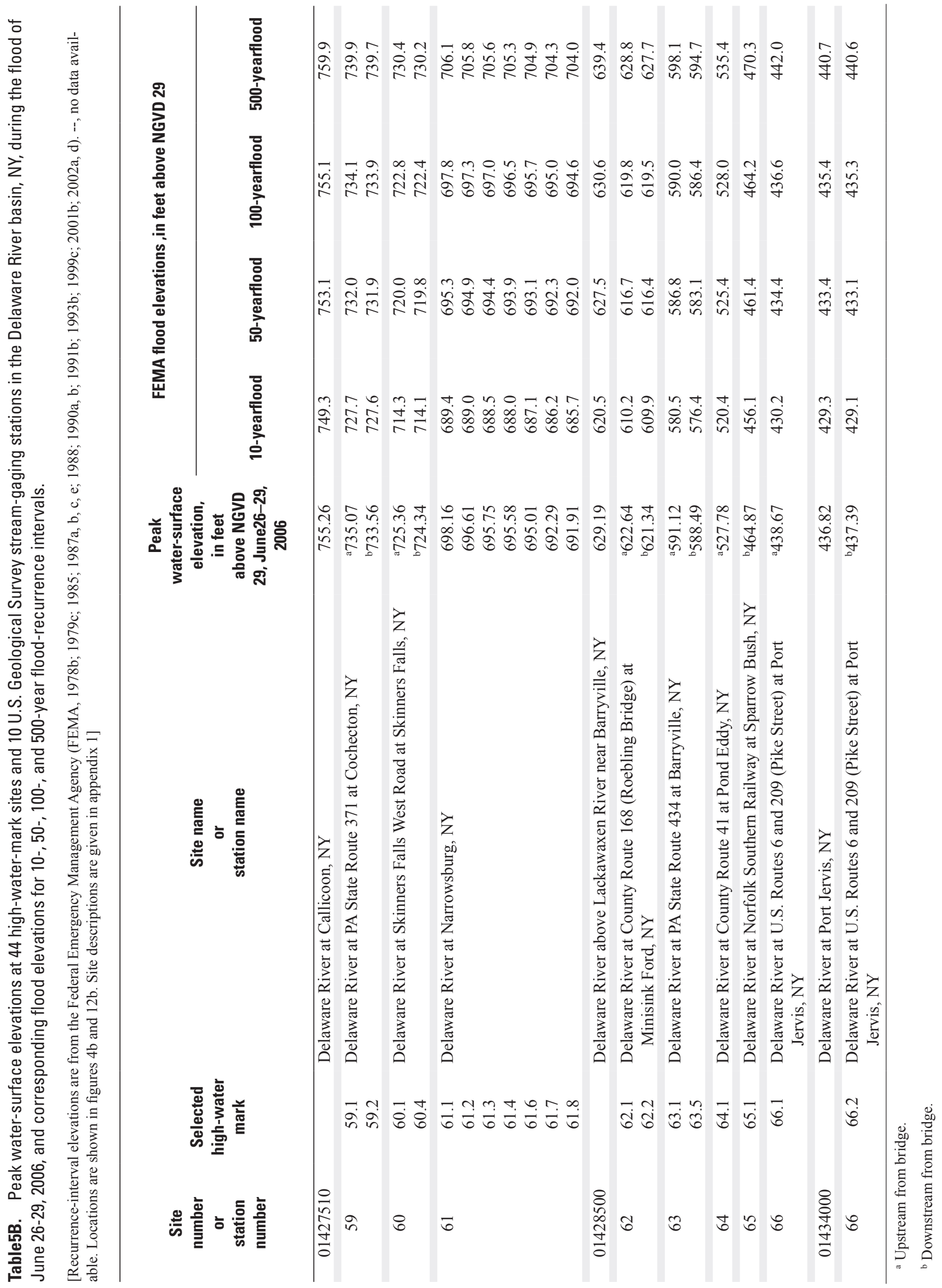




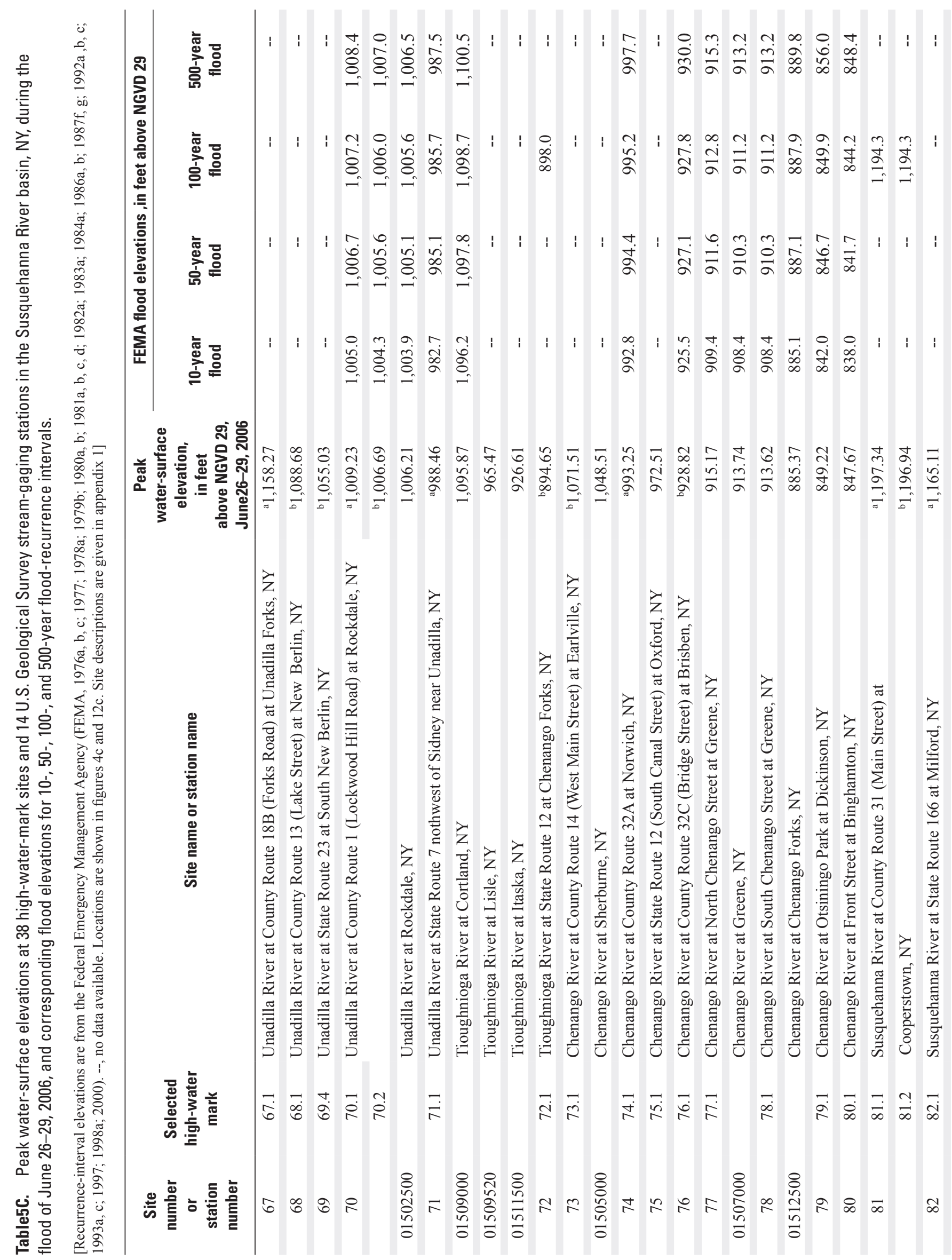




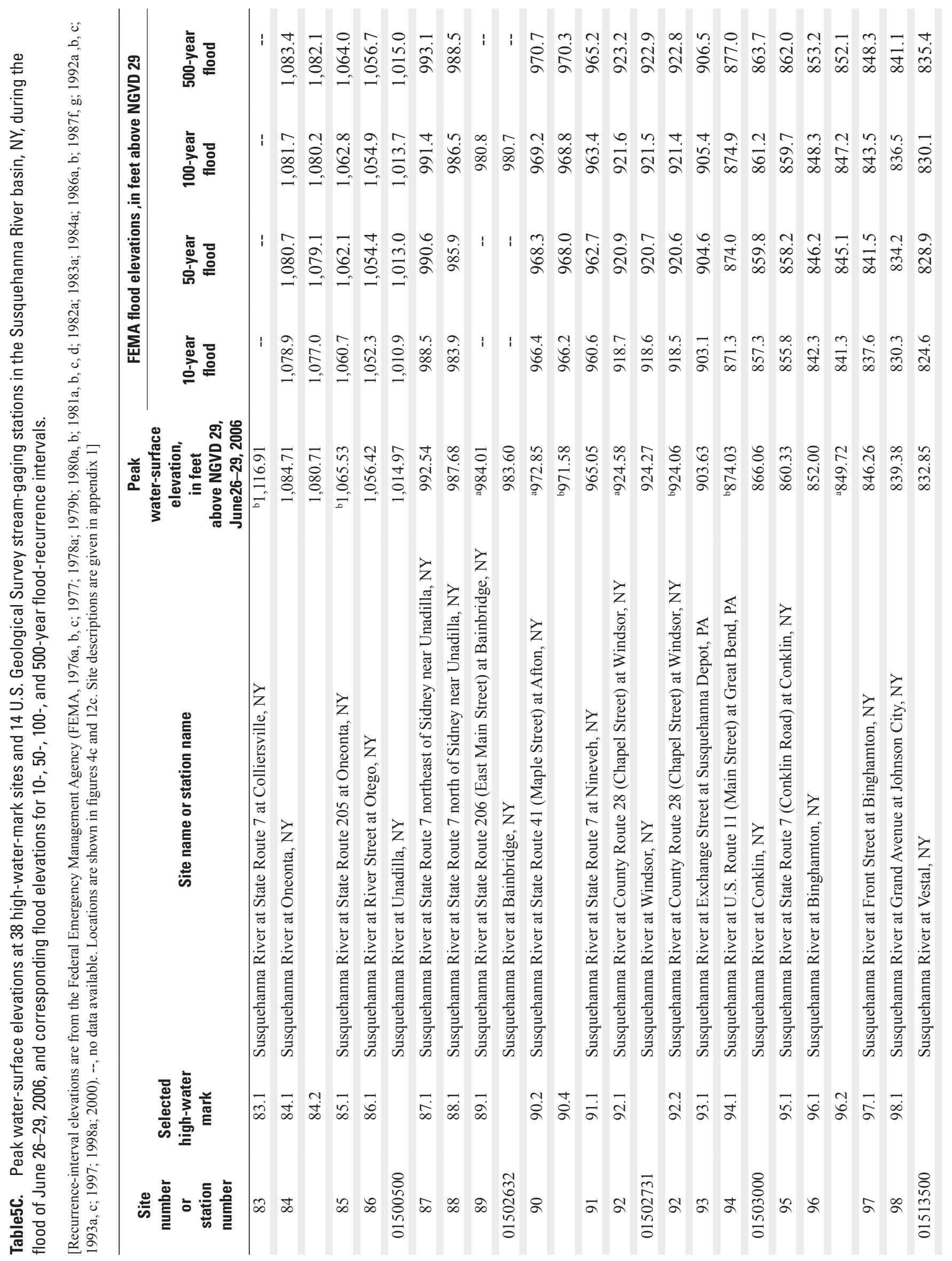




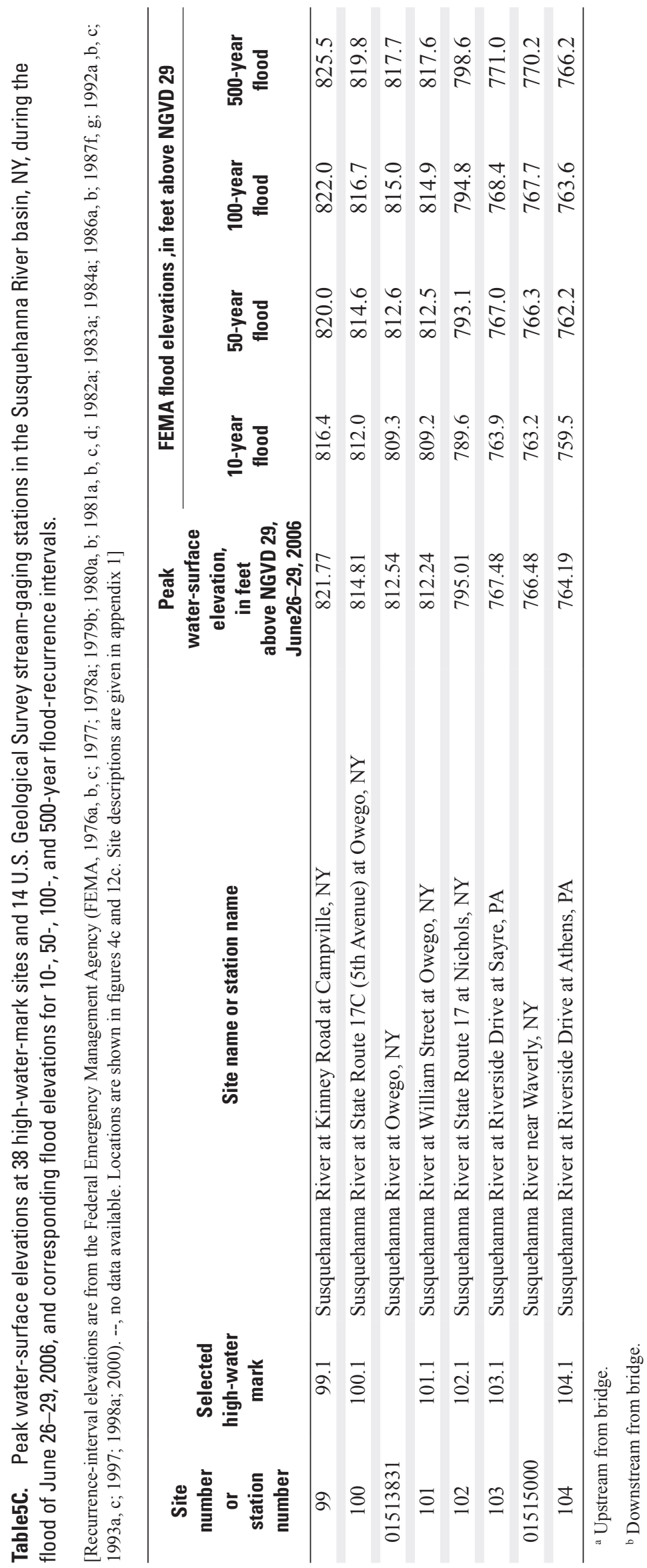




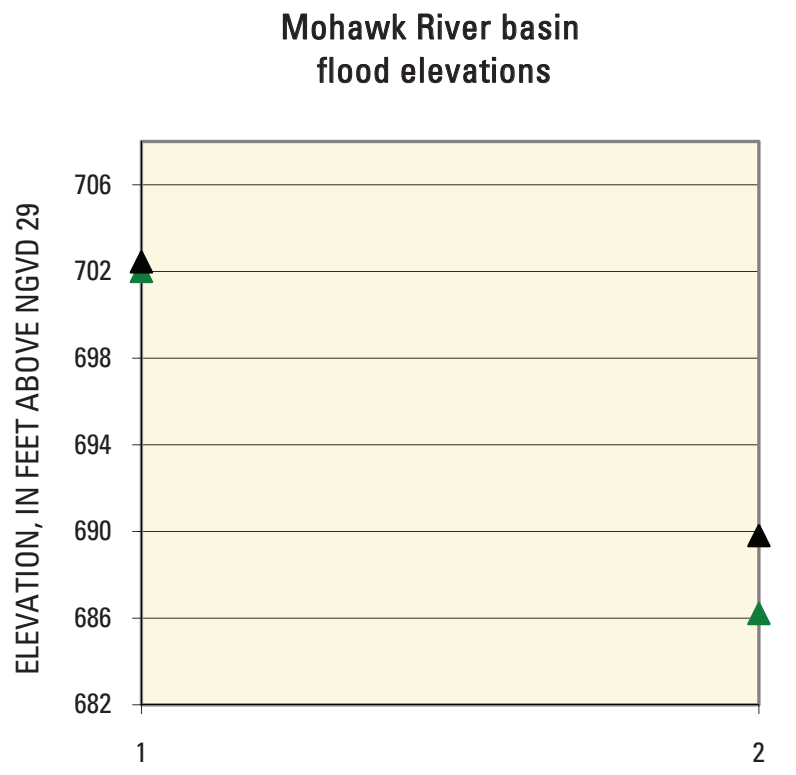

\section{Mohawk River basin flood elevations}
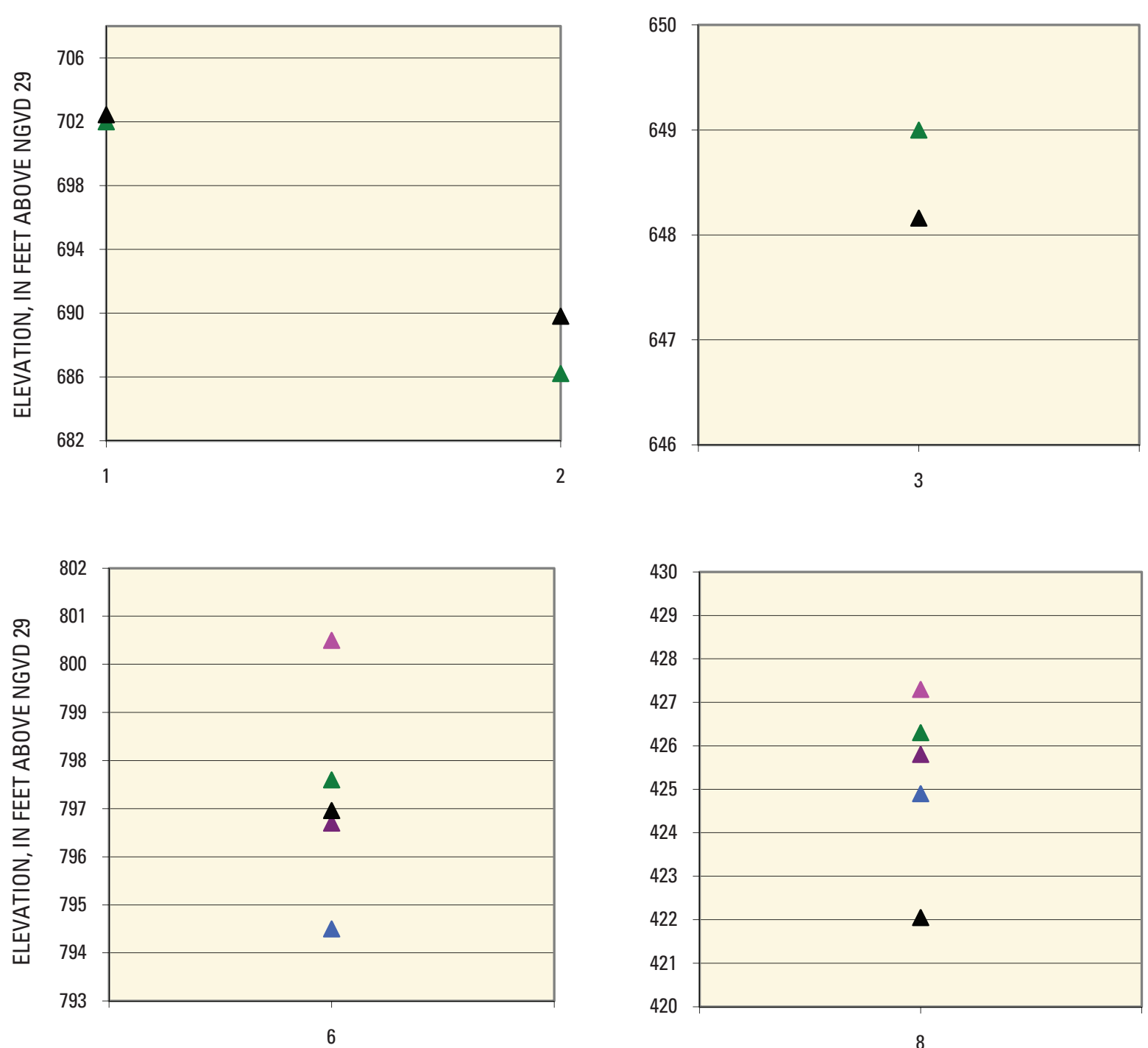

SITE NUMBER

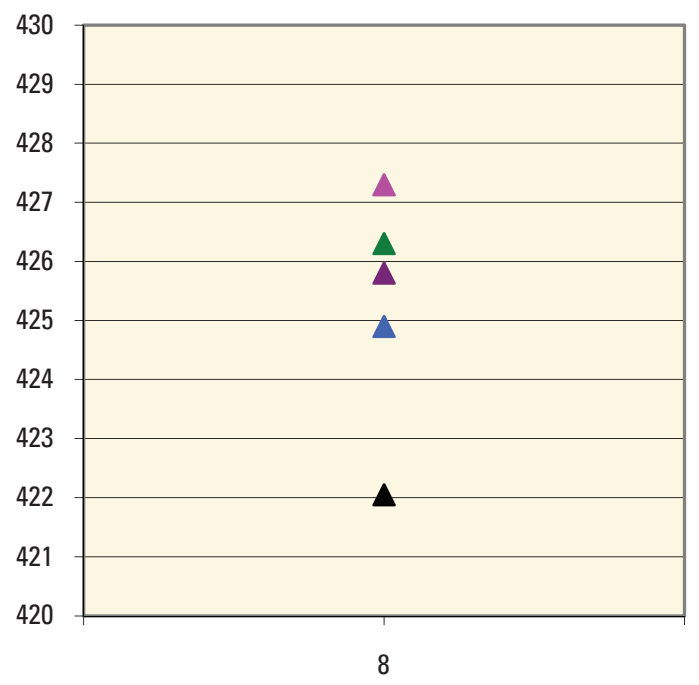

SITE NUMBER

\section{EXPLANATION}

$\Delta$ 500-year flood-recurrence-interval elevation (FEMA 1979a; 1982b, c, d, e, f; 1983b; 1984b; 1987d; 1991a; 1998b; 1999a, b; 2001a; 2002b, c)

$\Delta$ 100-year flood-recurrence-interval elevation (FEMA 1979a; 1982b, c, d, e, f; 1983b; 1984b; 1987d; 1991a; 1998b; 1999a, b; 2001a; 2002b, c)

$\Delta$ 50-year flood-recurrence-interval elevation (FEMA 1979a; 1982b, c, d, e, f; 1983b; 1984b; 1987d; 1991a; 1998b; 1999a, b; 2001a; 2002b, c)

$\Delta$ 10-year flood-recurrence-interval elevation (FEMA 1979a; 1982b, c, d, e, f; 1983b; 1984b; 1987d; 1991a; 1998b; 1999a, b; 2001a; 2002b, c)

$\Delta$ June 26-29, 2006, peak water-surface elevation (US Geological Survey)

Figure 13A. Peak water-surface elevations at selected sites in the Mohawk River basin, NY, during flood of June 26-29, 2006, and flood-recurrence-interval elevations from Federal Emergency Management Agency flood-insurance studies. (Site names and locations are shown in table 5.) 


\section{Mohawk River basin \\ flood elevations}
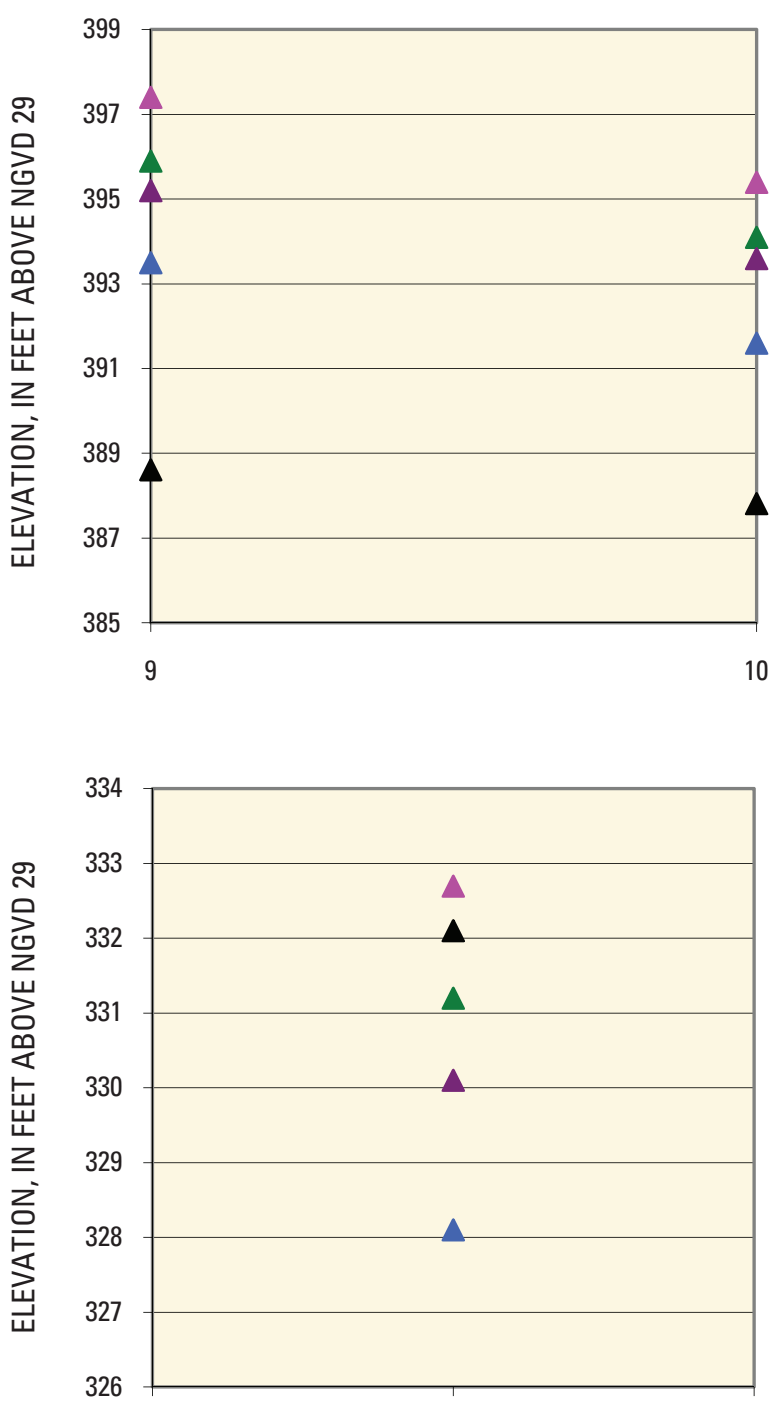

13

SITE NUMBER

\section{Mohawk River basin \\ flood elevations}
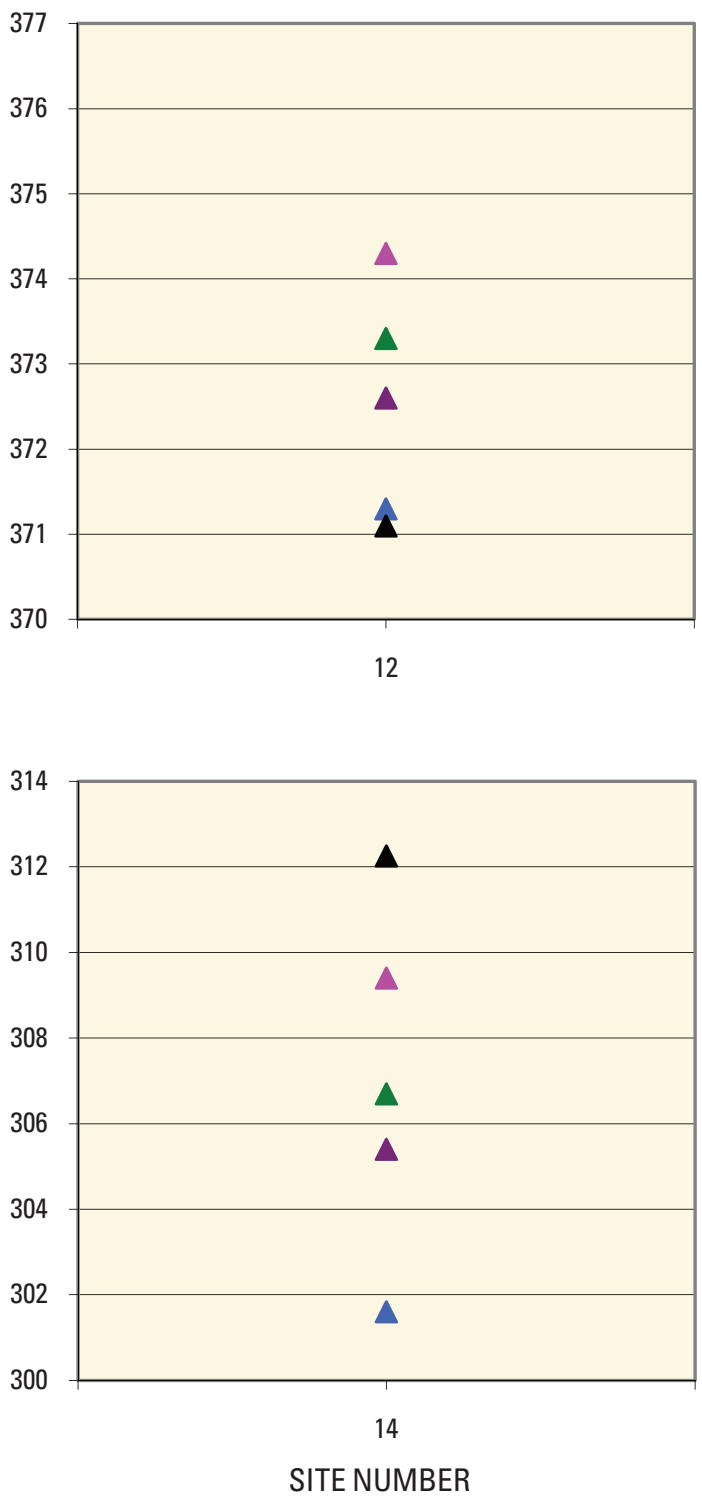

\section{EXPLANATION}

$\triangle 500$-year flood-recurrence-interval elevation (FEMA 1979a; 1982b, c, d, e, f; 1983b; 1984b; 1987d; 1991a; 1998b; 1999a, b; 2001a; 2002b, c)

100-year flood-recurrence-interval elevation (FEMA 1979a; 1982b, c, d, e, f; 1983b; 1984b; 1987d; 1991a; 1998b; 1999a, b; 2001a; 2002b, c)

$\Delta$ 50-year flood-recurrence-interval elevation (FEMA 1979a; 1982b, c, d, e, f; 1983b; 1984b; 1987d; 1991a; 1998b; 1999a, b; 2001a; 2002b, c)

$\Delta$ 10-year flood-recurrence-interval elevation (FEMA 1979a; 1982b, c, d, e, f; 1983b; 1984b; 1987d; 1991a; 1998b; 1999a, b; 2001a; 2002b, c)

$\Delta$ June 26-29, 2006, peak water-surface elevation (US Geological Survey)

Figure 13A. Peak water-surface elevations at selected sites in the Mohawk River basin, NY, during flood of June 26-29, 2006, and flood-recurrence-interval elevations from Federal Emergency Management Agency flood-insurance studies. (Site names and locations are shown in table 5.) 


\section{Mohawk River basin \\ flood elevations}
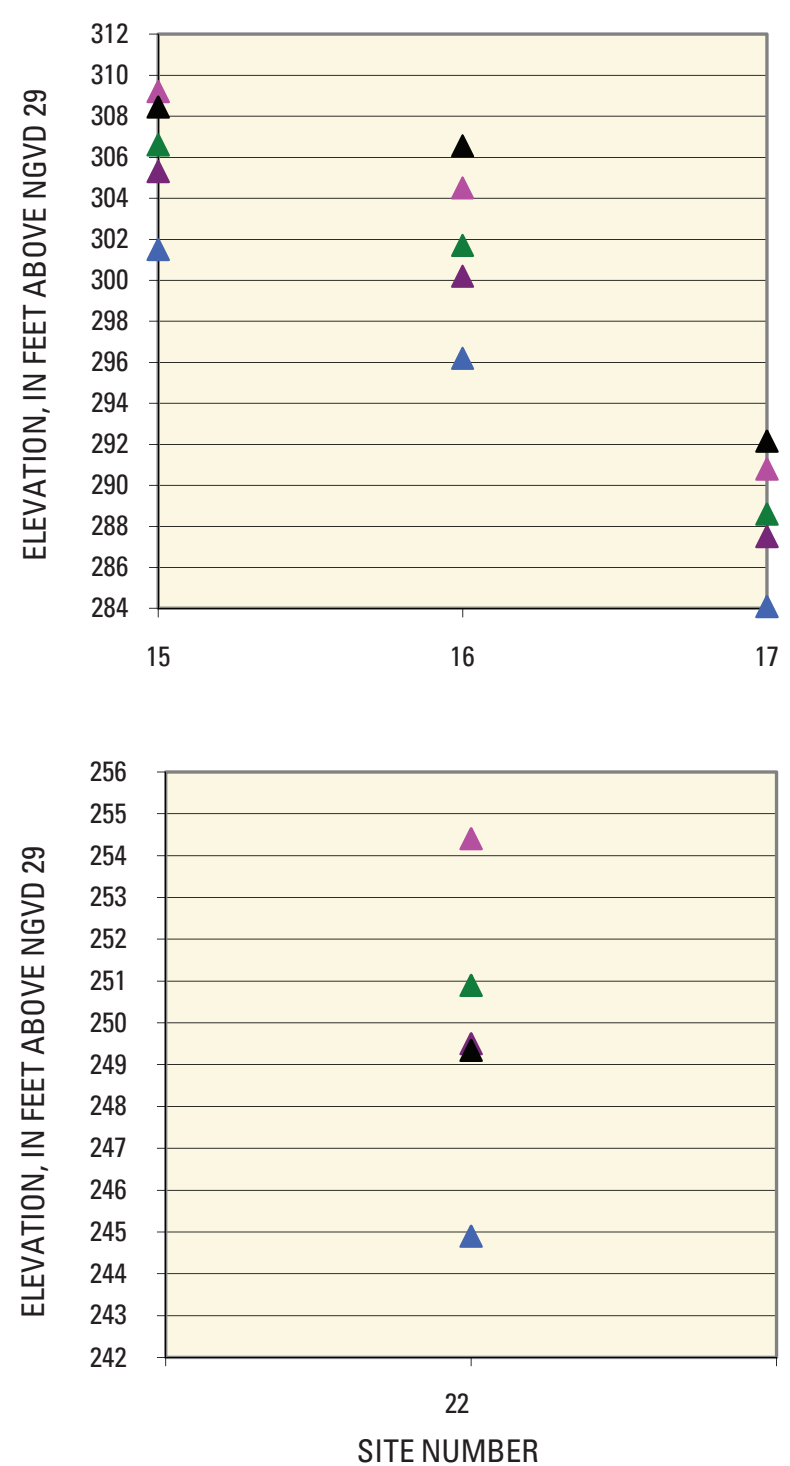

Mohawk River basin

flood elevations

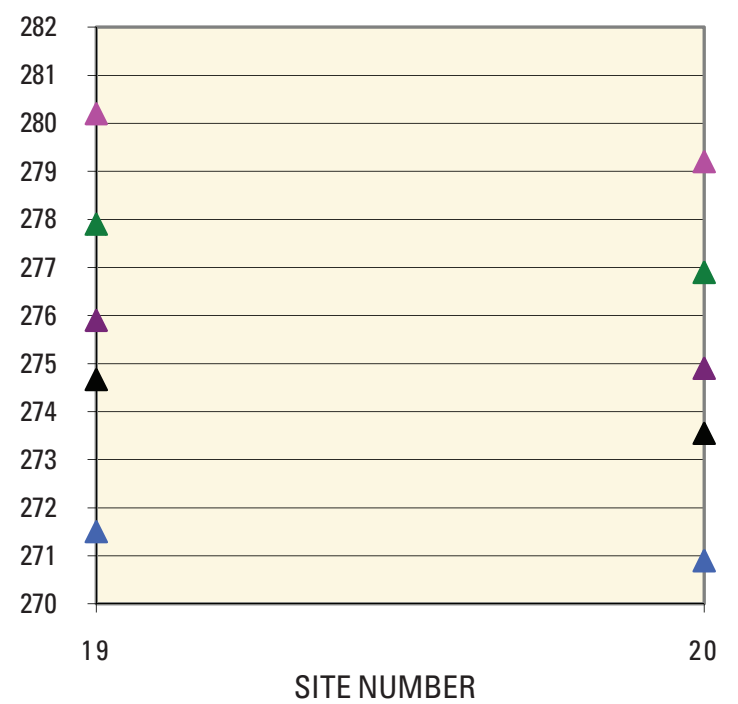

\section{EXPLANATION}

$\triangle$ 500-year flood-recurrence-interval elevation (FEMA 1979a; 1982b, c, d, e, f; 1983b; 1984b; 1987d; 1991a; 1998b; 1999a, b; 2001a; 2002b, c)

$\Delta$ 100-year flood-recurrence-interval elevation (FEMA 1979a; 1982b, c, d, e, f; 1983b; 1984b; 1987d; 1991a; 1998b; 1999a, b; 2001a; 2002b, c)

$\Delta$ 50-year flood-recurrence-interval elevation (FEMA 1979a; 1982b, c, d, e, f; 1983b; 1984b; 1987d; 1991a; 1998b; 1999a, b; 2001a; 2002b, c)

$\Delta$ 10-year flood-recurrence-interval elevation (FEMA 1979a; 1982b, c, d, e, f; 1983b; 1984b; 1987d; 1991a; 1998b; 1999a, b; 2001a; 2002b, c)

$\Delta$ June 26-29, 2006, peak water-surface elevation (US Geological Survey)

Figure 13A. Peak water-surface elevations at selected sites in the Mohawk River basin, NY, during flood of June 26-29, 2006, and flood-recurrence-interval elevations from Federal Emergency Management Agency flood-insurance studies. (Site names and locations are shown in table 5.) 
Delaware River basin flood elevations

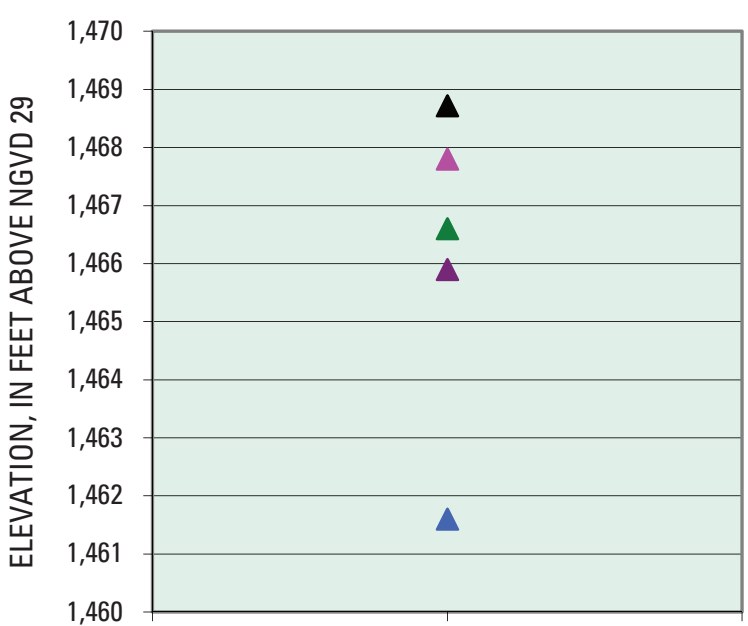

23

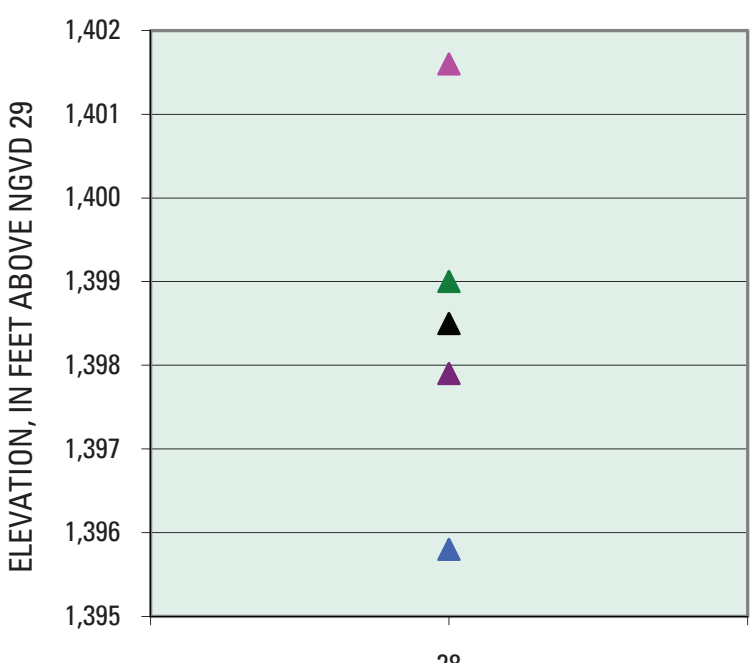

28

SITE NUMBER

\section{Delaware River basin flood elevations}
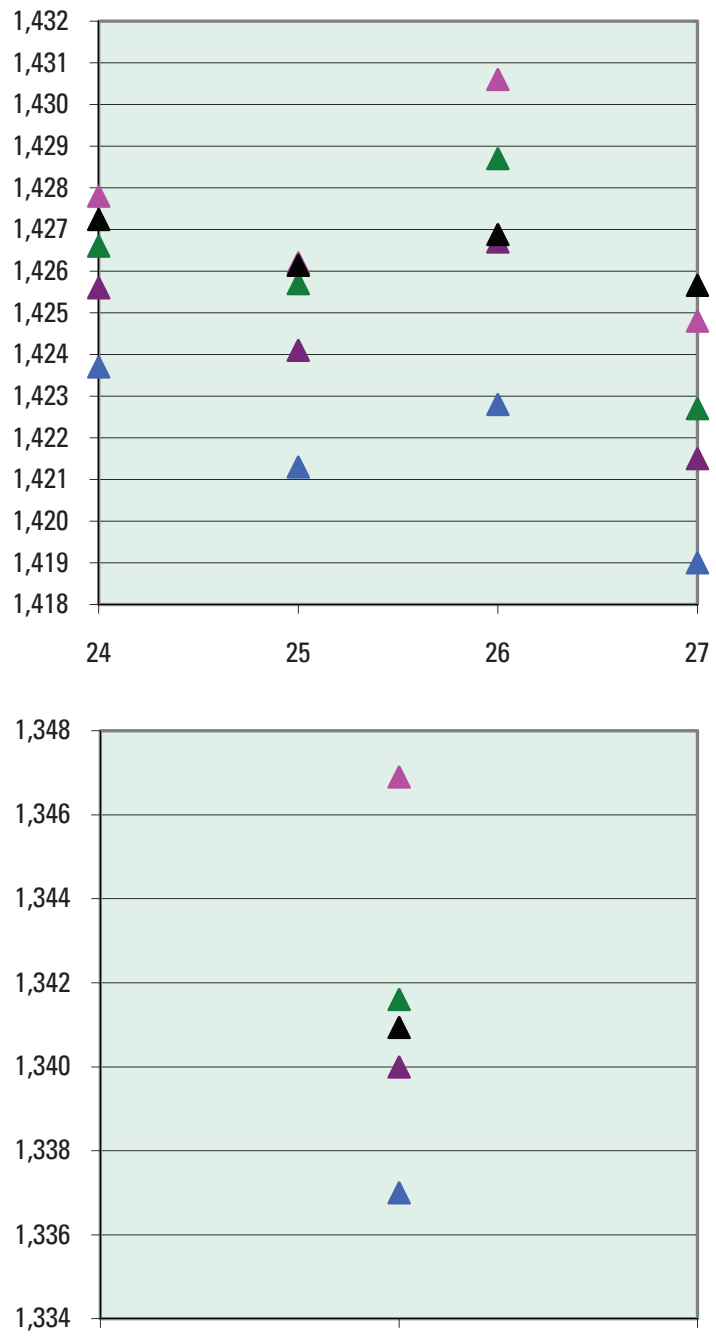

29

SITE NUMBER

\section{EXPLANATION}

A 500-year flood-recurrence-interval elevation (FEMA 1978b; 1979c; 1985; 1987a, b, c, e; 1988; 1990a, b; 1991b; 1993b; 1999c; 2001b; 2002a, d)

$\Delta$ 100-year flood-recurrence-interval elevation (FEMA 1978b; 1979c; 1985; 1987a, b, c, e; 1988; 1990a, b; 1991b; 1993b; 1999c; 2001b; 2002a, d)

$\Delta$ 50-year flood-recurrence-interval elevation (FEMA 1978b; 1979c; 1985; 1987a, b, c, e; 1988; 1990a, b; 1991b; 1993b; 1999c; 2001b; 2002a, d)

$\Delta$ 10-year flood-recurrence-interval elevation (FEMA 1978b; 1979c; 1985; 1987a, b, c, e; 1988; 1990a, b; 1991b; 1993b; 1999c; 2001b; 2002a, d)

$\Delta$ June 26-29, 2006, peak water-surface elevation (US Geological Survey)

Figure 13B. Peak water-surface elevations at selected sites in the Delaware River basin, NY, during flood of June 26-29, 2006, and flood-recurrence-interval elevations from Federal Emergency Management Agency flood-insurance studies. (Site names and locations are shown in table 5.) 


\section{Delaware River basin flood elevations}

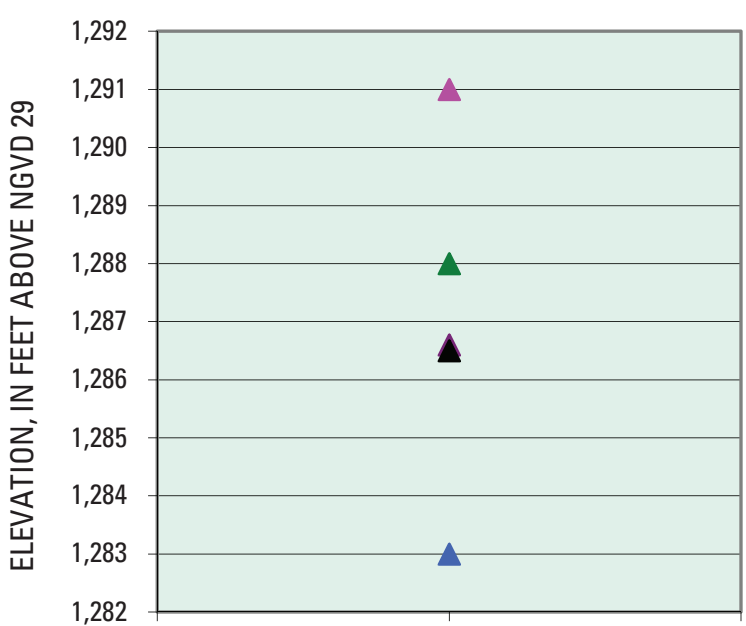

30

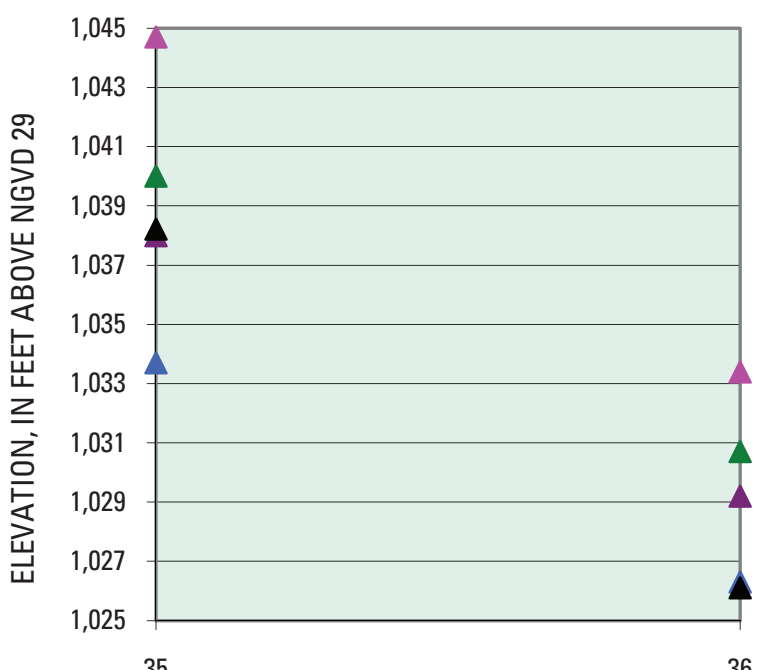

SITE NUMBER

\section{Delaware River basin flood elevations}

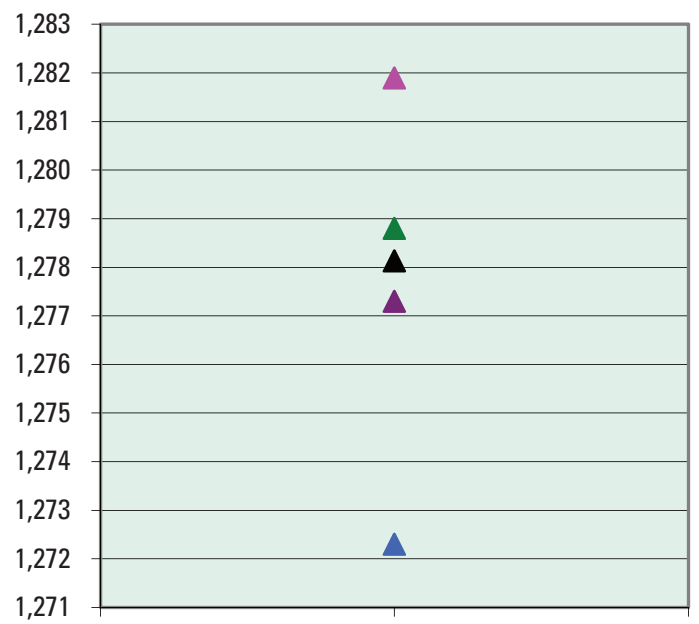

32

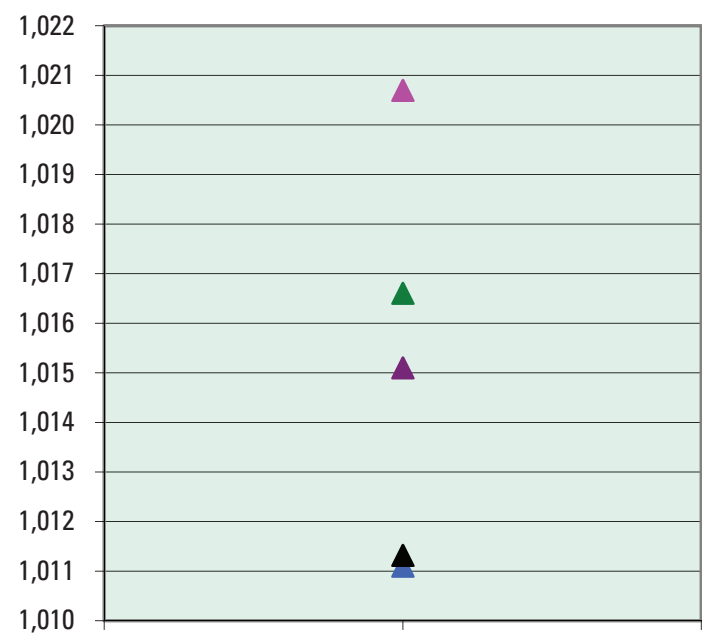

37

SITE NUMBER

\section{EXPLANATION}

$\Delta$ 500-year flood-recurrence-interval elevation (FEMA 1978b; 1979c; 1985; 1987a, b, c, e; 1988; 1990a, b; 1991b; 1993b; 1999c; 2001b; 2002a, d)

$\Delta$ 100-year flood-recurrence-interval elevation (FEMA 1978b; 1979c; 1985; 1987a, b, c, e; 1988; 1990a, b; 1991b; 1993b; 1999c; 2001b; 2002a, d)

$\Delta$ 50-year flood-recurrence-interval elevation (FEMA 1978b; 1979c; 1985; 1987a, b, c, e; 1988; 1990a, b; 1991b; 1993b; 1999c; 2001b; 2002a, d)

A 10-year flood-recurrence-interval elevation (FEMA 1978b; 1979c; 1985; 1987a, b, c, e; 1988; 1990a, b; 1991b; $1993 b ; 1999 c ; 2001 b ; 2002 a, d)$

$\Delta$ June 26-29, 2006, peak water-surface elevation (US Geological Survey)

Figure 13B. Peak water-surface elevations at selected sites in the Delaware River basin, NY, during flood of June 26-29, 2006, and flood-recurrence-interval elevations from Federal Emergency Management Agency flood-insurance studies. (Site names and locations are shown in table 5.)v 
Delaware River basin

flood elevations

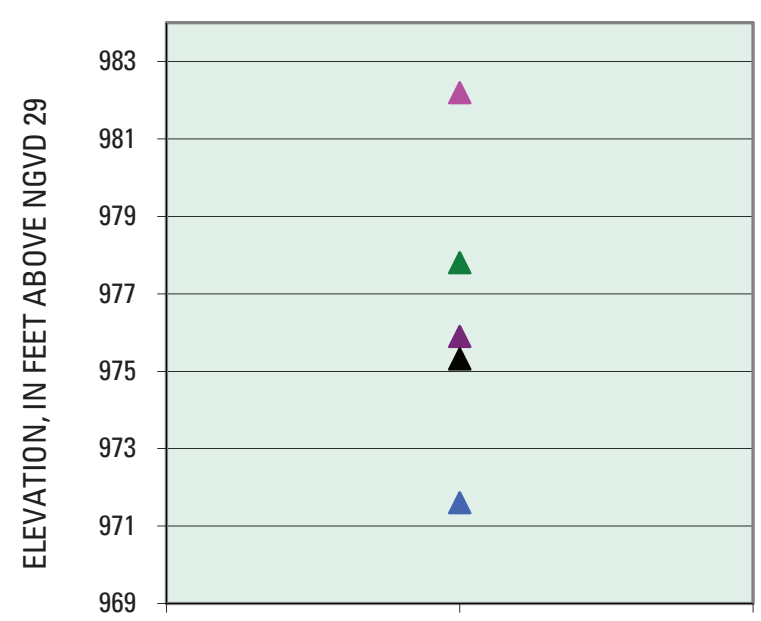

38

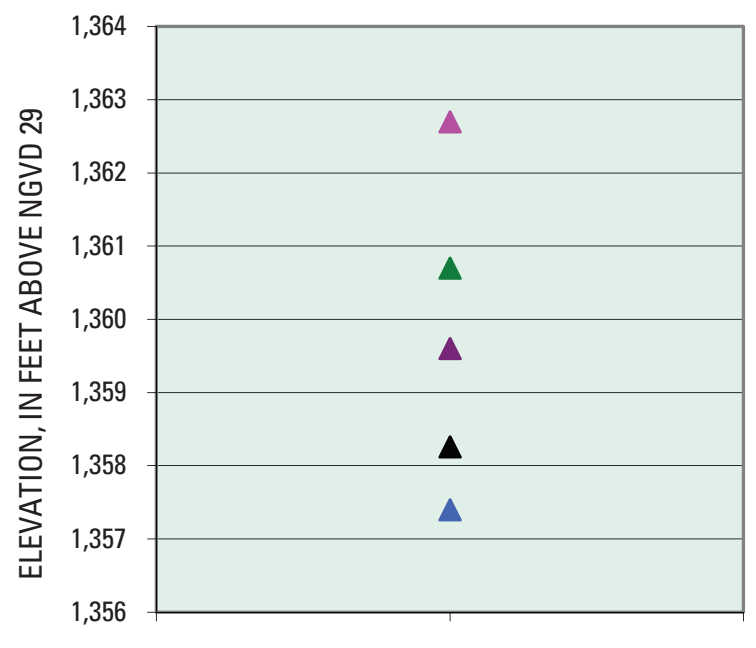

41

SITE NUMBER

\section{Delaware River basin flood elevations}
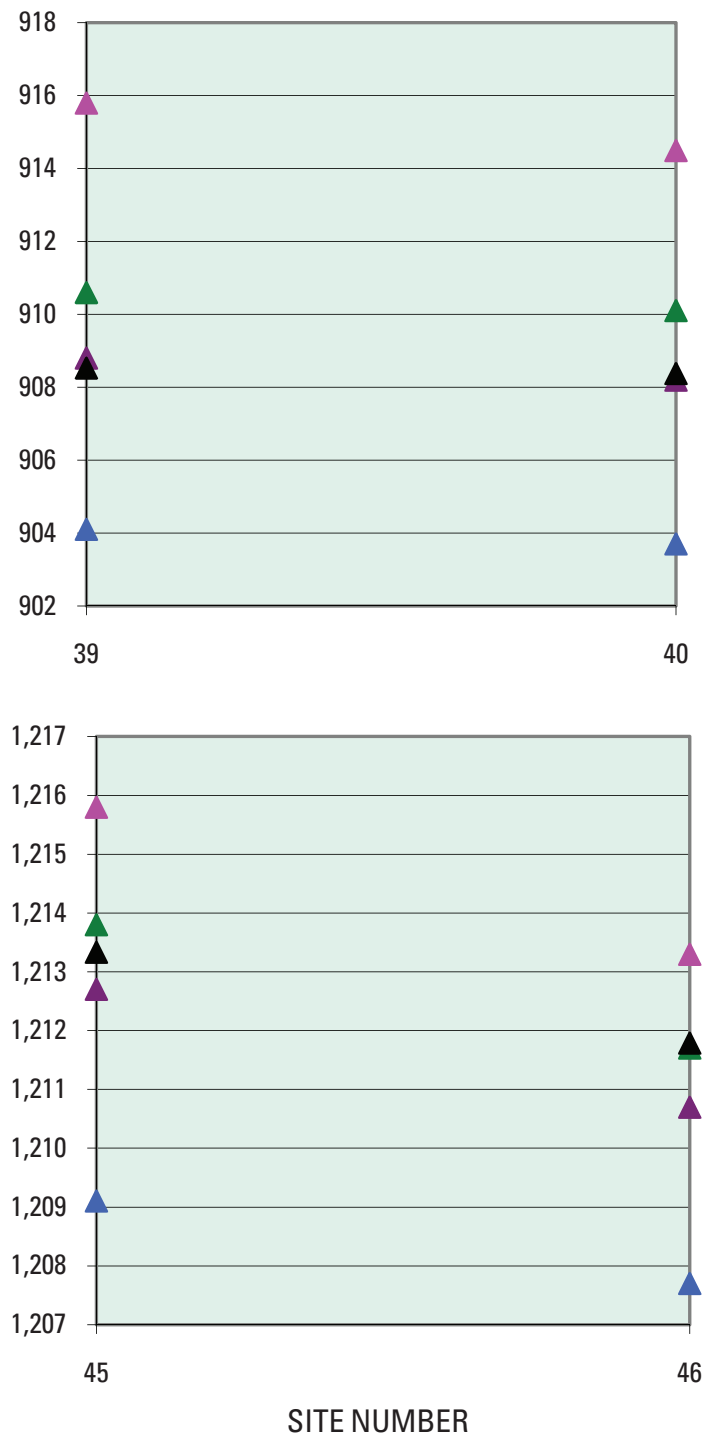

\section{EXPLANATION}

$\Delta$ 500-year flood-recurrence-interval elevation (FEMA 1978b; 1979c; 1985; 1987a, b, c, e; 1988; 1990a, b; 1991b; 1993b; 1999c; 2001b; 2002a, d)

$\Delta$ 100-year flood-recurrence-interval elevation (FEMA 1978b; 1979c; 1985; 1987a, b, c, e; 1988; 1990a, b; 1991b; 1993b; 1999c; 2001b; 2002a, d)

$\Delta$ 50-year flood-recurrence-interval elevation (FEMA 1978b; 1979c; 1985; 1987a, b, c, e; 1988; 1990a, b; 1991b; 1993b; 1999c; 2001b; 2002a, d)

10-year flood-recurrence-interval elevation (FEMA 1978b; 1979c; 1985; 1987a, b, c, e; 1988; 1990a, b; 1991b; 1993b; 1999c; 2001b; 2002a, d)

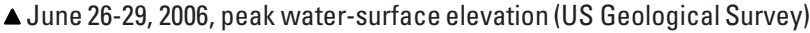

Figure 13B. Peak water-surface elevations at selected sites in the Delaware River basin, NY, during flood of June 26-29, 2006, and flood-recurrence-interval elevations from Federal Emergency Management Agency flood-insurance studies. (Site names and locations are shown in table 5.) 


\section{Delaware River basin \\ flood elevations}

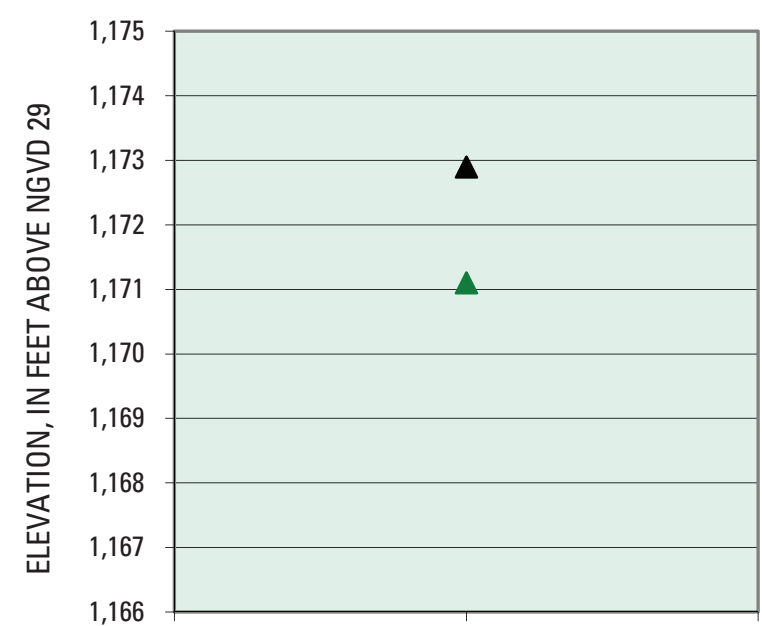

47

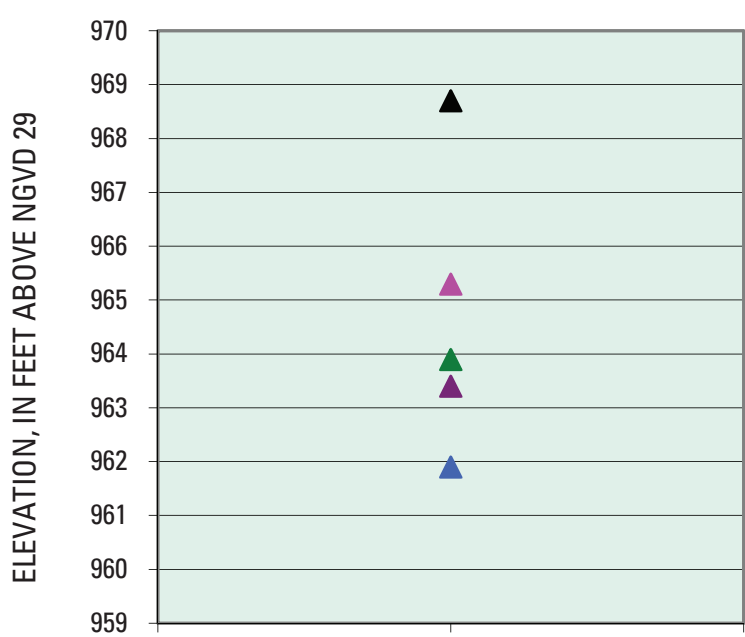

50

SITE NUMBER
Delaware River basin flood elevations

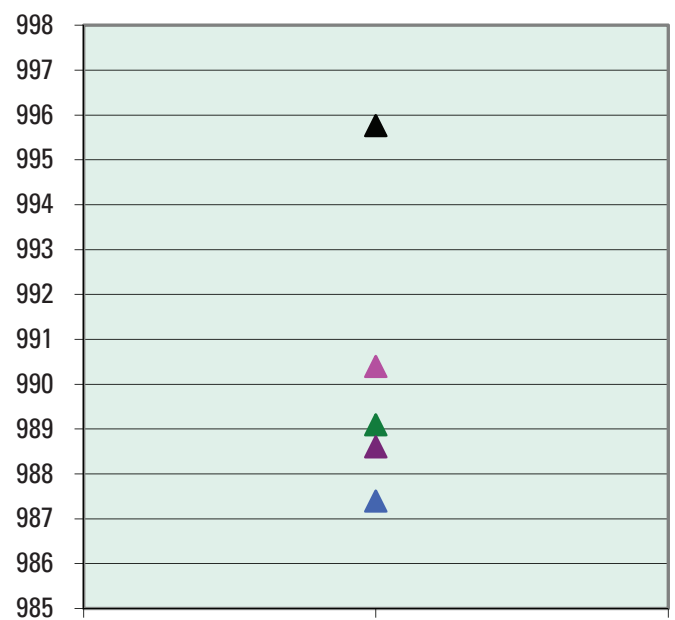

48

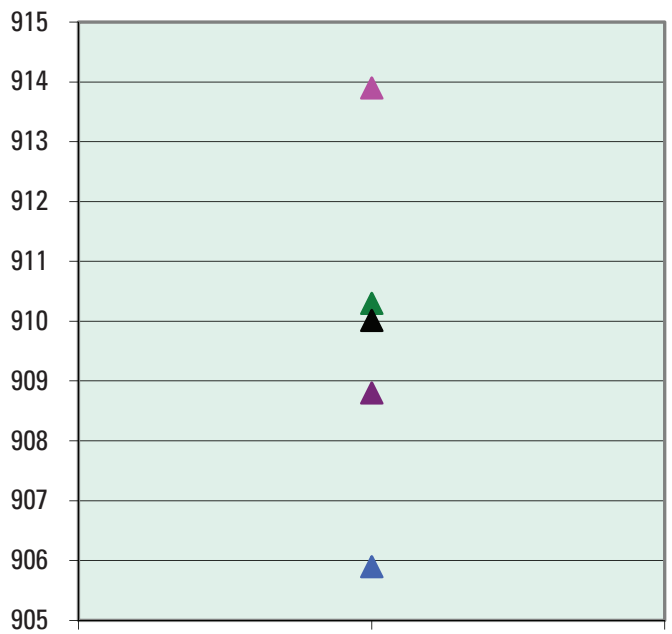

51

SITE NUMBER

\section{EXPLANATION}

$\triangle 500$-year flood-recurrence-interval elevation (FEMA 1978b; 1979c; 1985; 1987a, b, c, e; 1988; 1990a, b; 1991b; 1993b; 1999c; 2001b; 2002a, d)

$\Delta$ 100-year flood-recurrence-interval elevation (FEMA 1978b; 1979c; 1985; 1987a, b, c, e; 1988; 1990a, b; 1991 b; 1993b; 1999c; 2001b; 2002a, d)

$\Delta 50$-year flood-recurrence-interval elevation (FEMA 1978b; 1979c; 1985; 1987a, b, c, e; 1988; 1990a, b; 1991b; 1993b; 1999c; 2001b; 2002a, d)

A 10-year flood-recurrence-interval elevation (FEMA 1978b; 1979c; 1985; 1987a, b, c, e; 1988; 1990a, b; 1991b;

1993b; 1999c; 2001b; 2002a, d)

\ June 26-29, 2006, peak water-surface elevation (US Geological Survey)

Figure 13B. Peak water-surface elevations at selected sites in the Delaware River basin, NY, during flood of June 26-29, 2006, and flood-recurrence-interval elevations from Federal Emergency Management Agency flood-insurance studies. (Site names and locations are shown in table 5.) 


\section{Delaware River basin flood elevations}

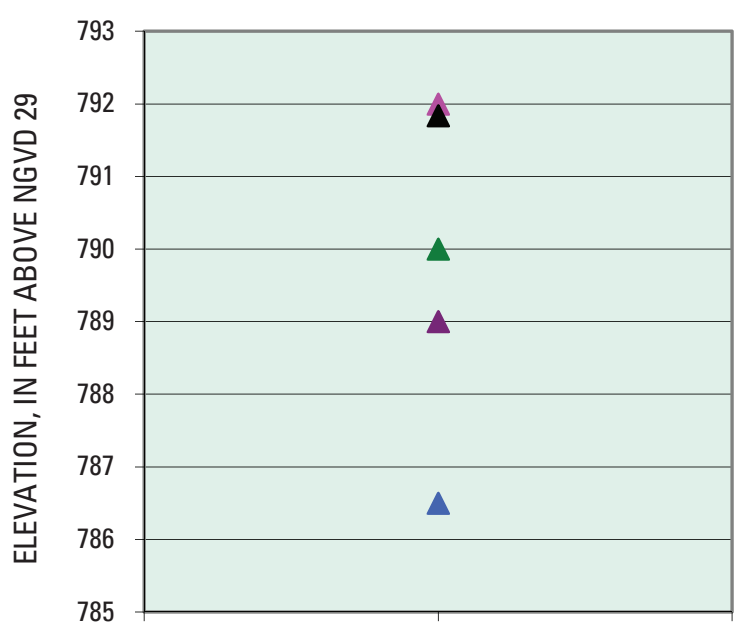

54

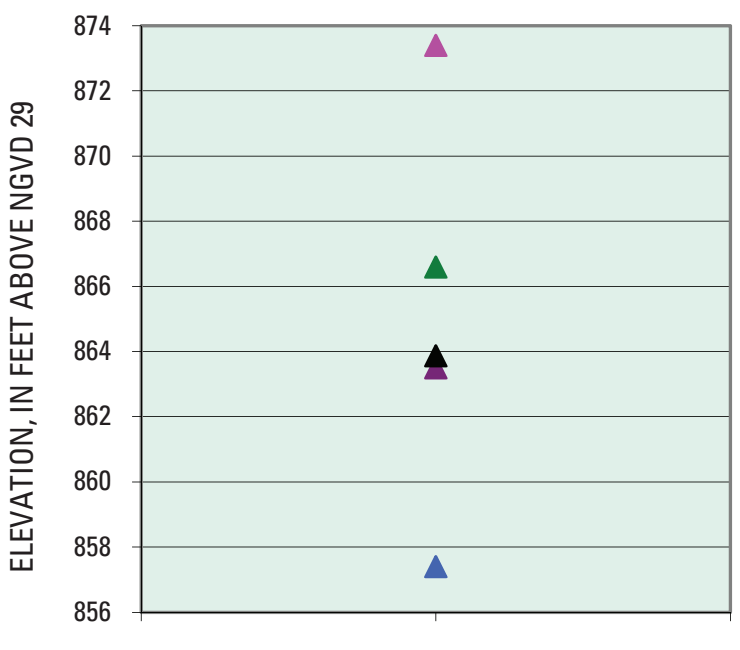

57

SITE NUMBER
Delaware River basin flood elevations
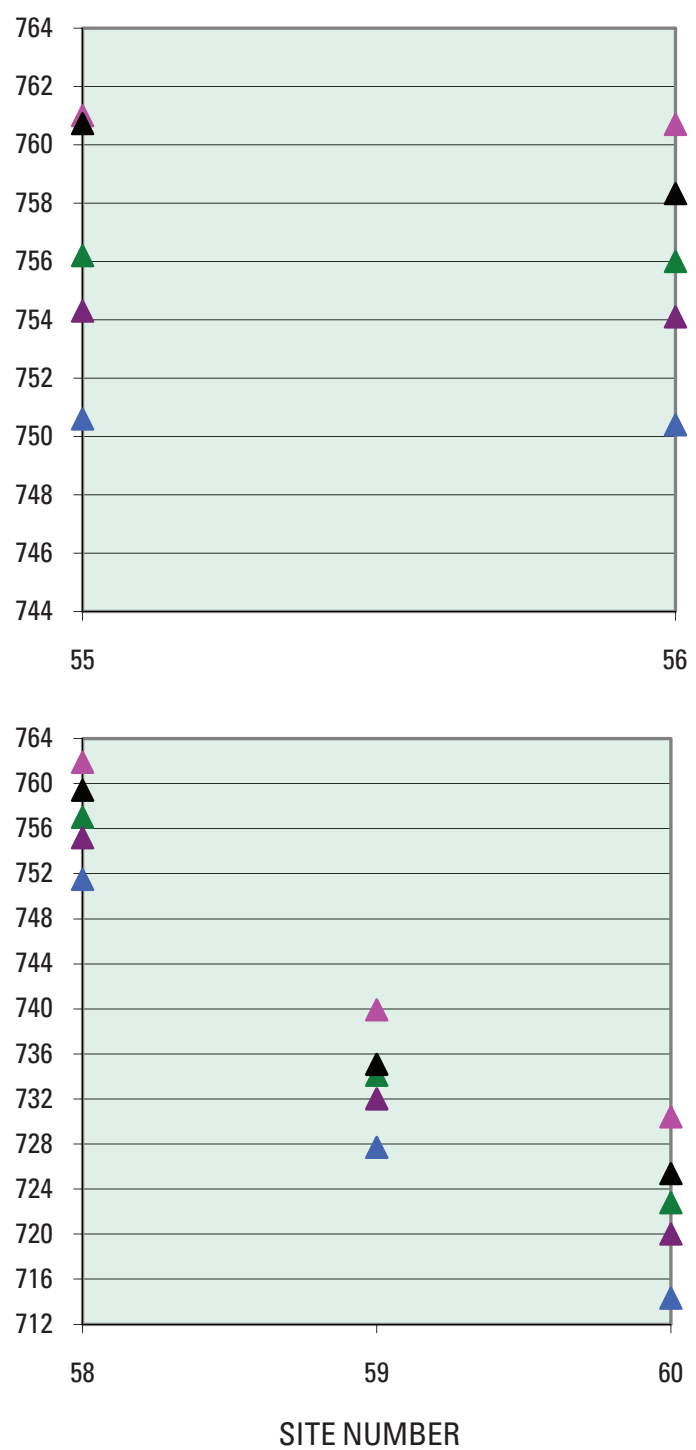

\section{EXPLANATION}

$\Delta$ 500-year flood-recurrence-interval elevation (FEMA 1978b; 1979c; 1985; 1987a, b, c, e; 1988; 1990a, b; 1991b; 1993b; 1999c; 2001b; 2002a, d)

$\Delta$ 100-year flood-recurrence-interval elevation (FEMA 1978b; 1979c; 1985; 1987a, b, c, e; 1988; 1990a, b; 1991b; 1993b; 1999c; 2001b; 2002a, d)

$\Delta$ 50-year flood-recurrence-interval elevation (FEMA 1978b; 1979c; 1985; 1987a, b, c, e; 1988; 1990a, b; 1991b; 1993b; 1999c; 2001b; 2002a, d)

$\Delta$ 10-year flood-recurrence-interval elevation (FEMA 1978b; 1979c; 1985; 1987a, b, c, e; 1988; 1990a, b; 1991b; 1993b; 1999c; 2001b; 2002a, d)

$\Delta$ June 26-29, 2006, peak water-surface elevation (US Geological Survey)

Figure 13B. Peak water-surface elevations at selected sites in the Delaware River basin, NY, during flood of June 26-29, 2006, and flood-recurrence-interval elevations from Federal Emergency Management Agency flood-insurance studies. (Site names and locations are shown in table 5.) 


\section{Delaware River basin \\ flood elevations}
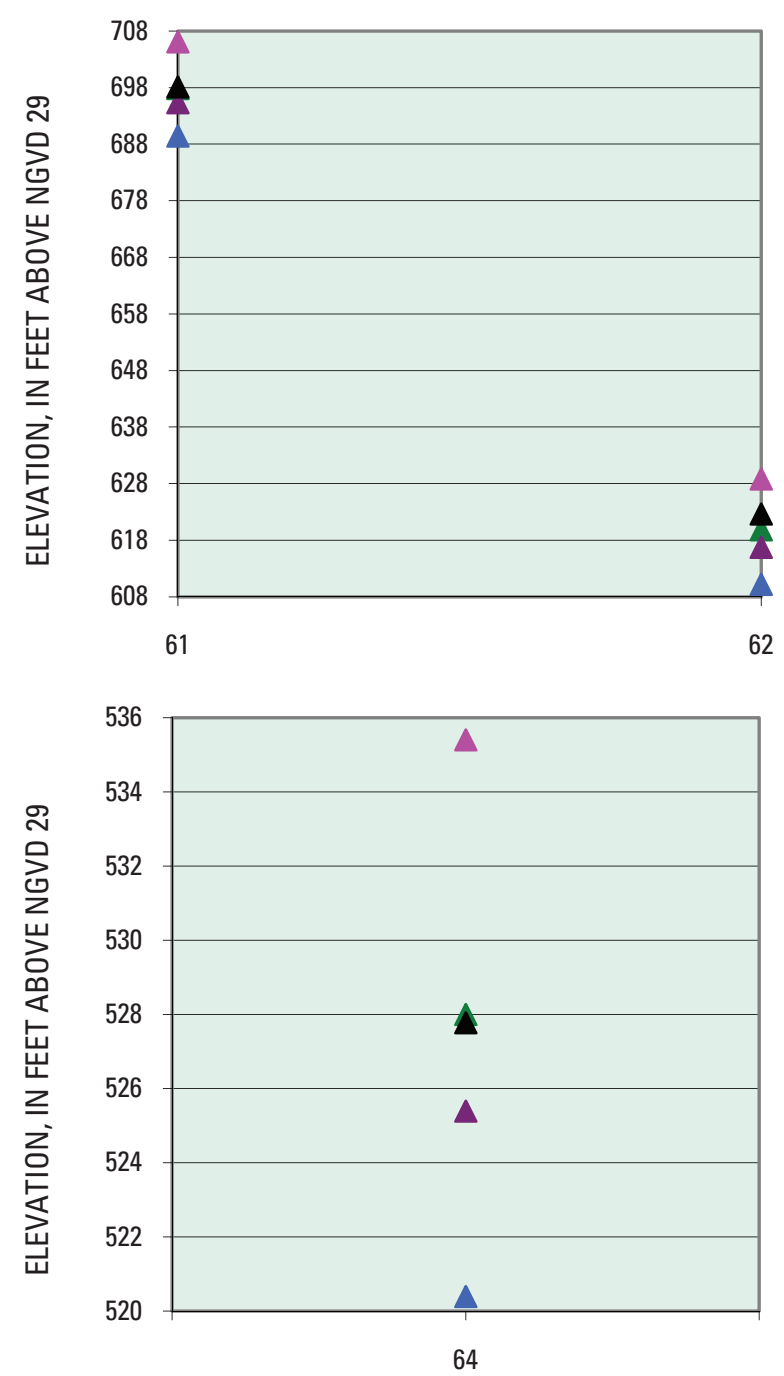

SITE NUMBER

\section{Delaware River basin flood elevations}

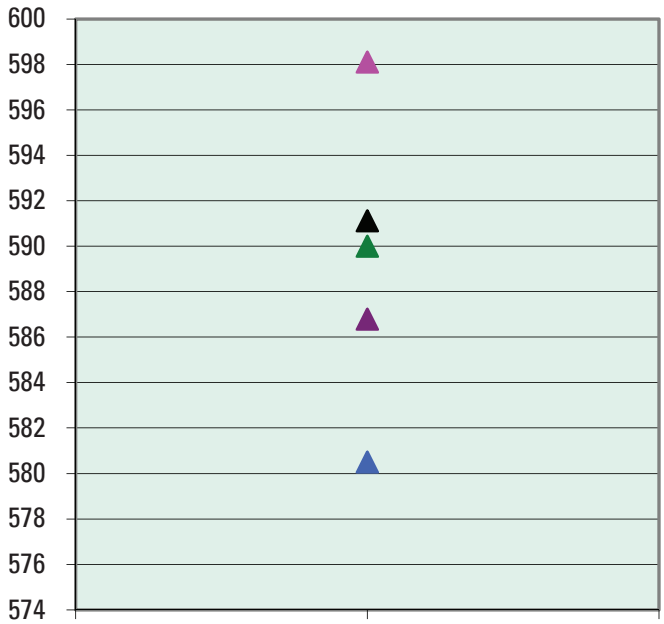

63

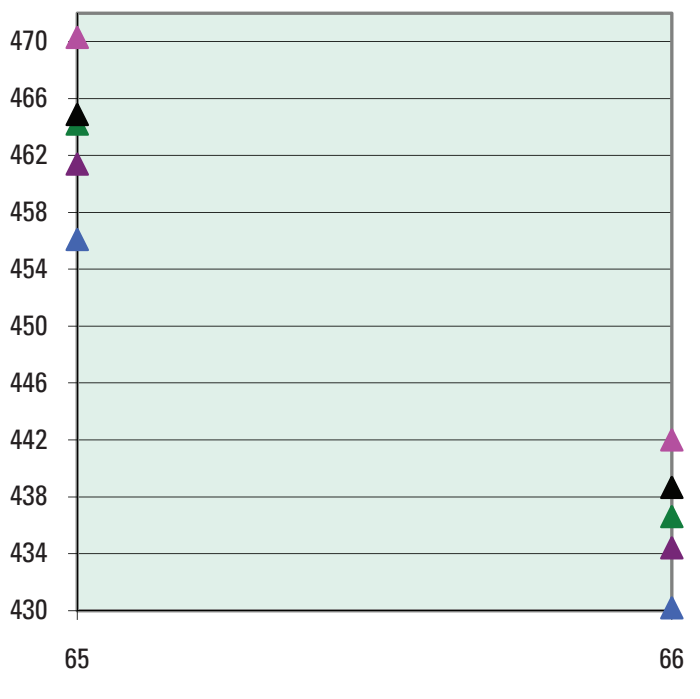

SITE NUMBER

\section{EXPLANATION}

$\triangle 500$-year flood-recurrence-interval elevation (FEMA 1978b; 1979c; 1985; 1987a, b, c, e; 1988; 1990a, b; 1991 b; 1993b; 1999c; 2001b; 2002a, d)

$\Delta$ 100-year flood-recurrence-interval elevation (FEMA 1978b; 1979c; 1985; 1987a, b, c, e; 1988; 1990a, b; 1991b; 1993b; 1999c; 2001b; 2002a, d)

$\Delta$ 50-year flood-recurrence-interval elevation (FEMA 1978b; 1979c; 1985; 1987a, b, c, e; 1988; 1990a, b; 1991b; 1993b; 1999c; 2001b; 2002a, d)

$\Delta$ 10-year flood-recurrence-interval elevation (FEMA 1978b; 1979c; 1985; 1987a, b, c, e; 1988; 1990a, b; 1991b; 1993b; 1999c; 2001b; 2002a, d)

$\Delta$ June 26-29, 2006, peak water-surface elevation (US Geological Survey)

Figure 13B. Peak water-surface elevations at selected sites in the Delaware River basin, NY, during flood of June 26-29, 2006, and flood-recurrence-interval elevations from Federal Emergency Management Agency flood-insurance studies. (Site names and locations are shown in table 5.) 


\section{Susquehanna River basin flood elevations}
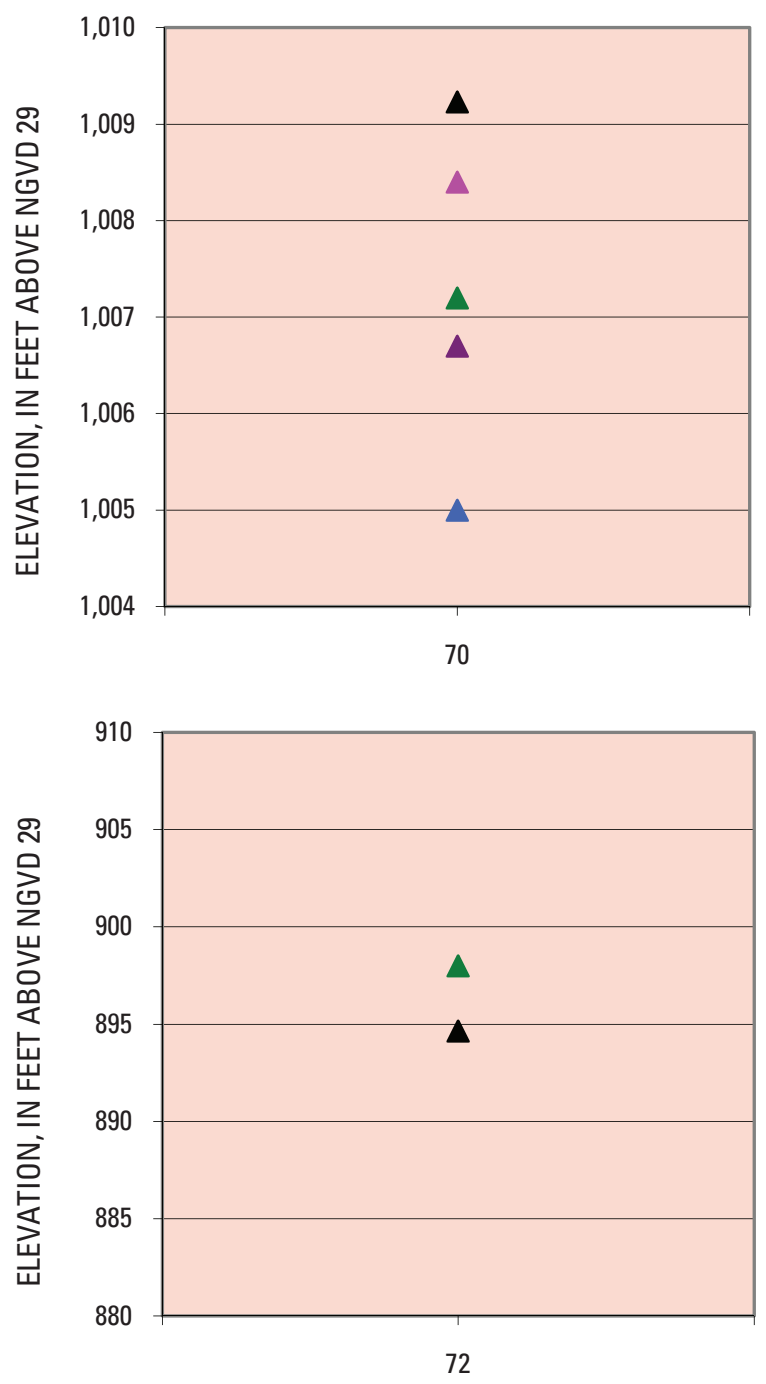

SITE NUMBER

\section{Susquehanna River basin flood elevations}
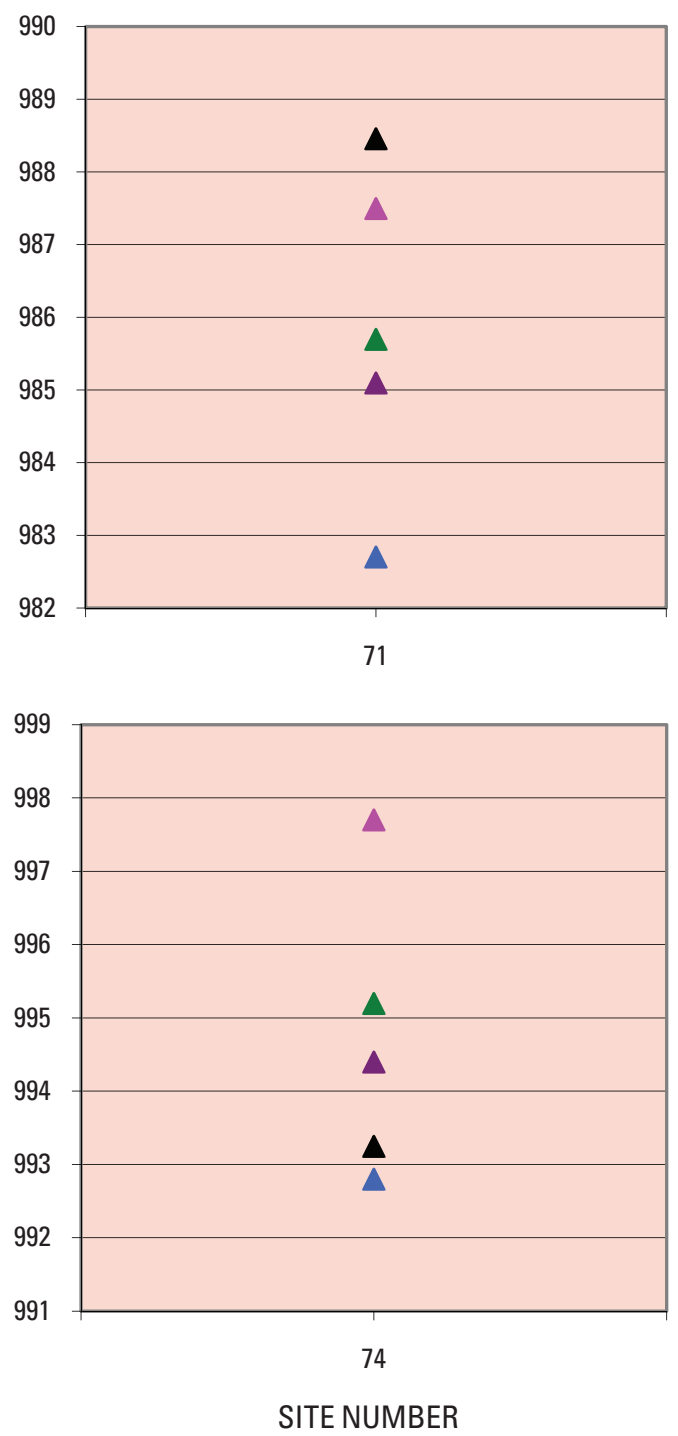

\section{EXPLANATION}

$\Delta$ 500-year flood-recurrence-interval elevation (FEMA 1976a, b, c; 1977; 1978a; 1979b; 1980a, b; 1981a, b, c, d; 1982a; 1983a; 1984a; 1986a, b; 1987f, g; 1992a ,b, c; 1993a, c; 1997; 1998a; 2000)

\ 100-year flood-recurrence-interval elevation (FEMA 1976a, b, c; 1977; 1978a; 1979b; 1980a, b; 1981a, b, c, d; 1982a; 1983a; 1984a; 1986a, b; 1987f, g; 1992a ,b, c; 1993a, c; 1997; 1998a; 2000)

$\Delta$ 50-year flood-recurrence-interval elevation (FEMA 1976a, b, c; 1977; 1978a; 1979b; 1980a, b; 1981a, b, c, d; 1982a; 1983a; 1984a; 1986a, b; 1987f, g; 1992a ,b, c; 1993a, c; 1997; 1998a; 2000)

A 10-year flood-recurrence-interval elevation (FEMA 1976a, b, c; 1977; 1978a; 1979b; 1980a, b; 1981a, b, c, d; 1982a; 1983a; 1984a; 1986a, b; 1987f, g; 1992a ,b, c; 1993a, c; 1997; 1998a; 2000)

\ June 26-29, 2006, peak water-surface elevation (US Geological Survey)

Figure 13C. Peak water-surface elevations at selected sites in the Susquehanna River basin, NY, during flood of June 26-29, 2006, and flood-recurrence-interval elevations from Federal Emergency Management Agency floodinsurance studies. (Site names and locations are shown in table 5.) 


\section{Susquehanna River basin \\ flood elevations}

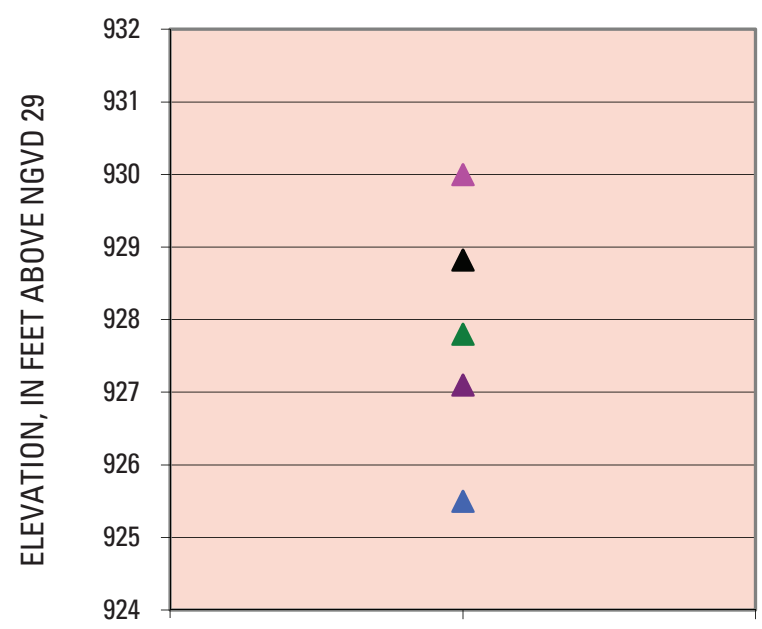

76

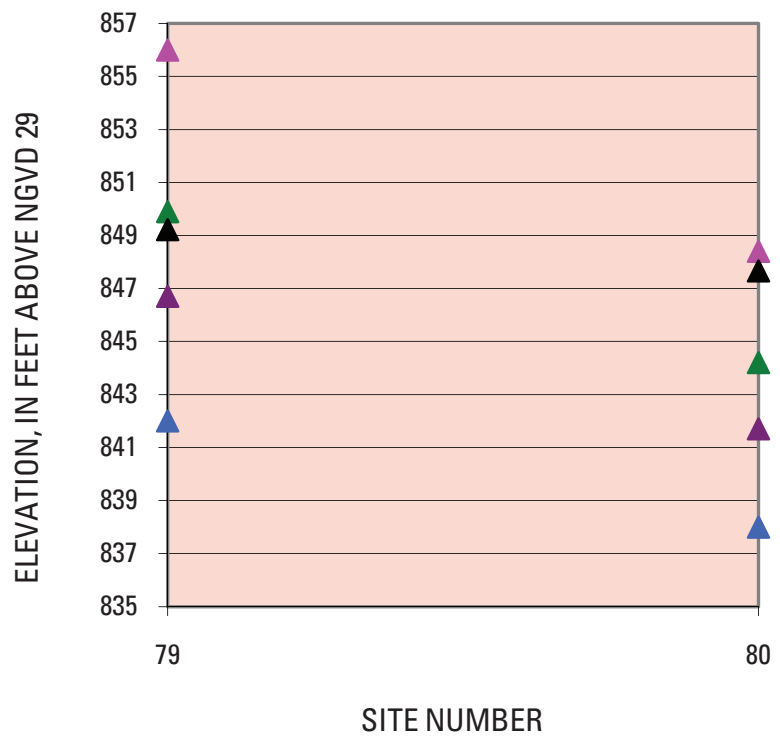

\section{Susquehanna River basin flood elevations}
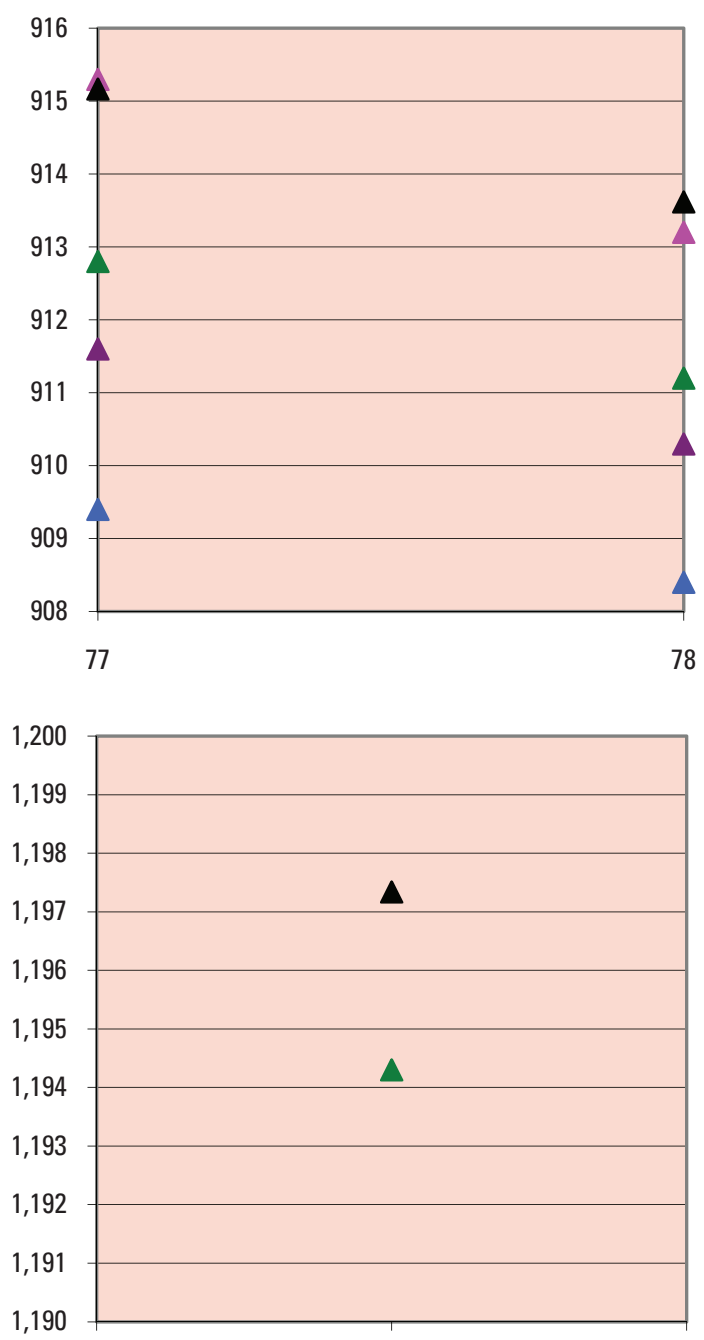

81

SITE NUMBER

\section{EXPLANATION}

$\Delta$ 500-year flood-recurrence-interval elevation (FEMA 1976a, b, c; 1977; 1978a; 1979b; 1980a, b; 1981a, b, c, d; 1982a; 1983a; 1984a; 1986a, b; 1987f, g; 1992a ,b, c; 1993a, c; 1997; 1998a; 2000)

$\Delta$ 100-year flood-recurrence-interval elevation (FEMA 1976a, b, c; 1977; 1978a; 1979b; 1980a, b; 1981a, b, c, d; 1982a; 1983a; 1984a; 1986a, b; 1987f, g; 1992a ,b, c; 1993a, c; 1997; 1998a; 2000)

$\Delta$ 50-year flood-recurrence-interval elevation (FEMA 1976a, b, c; 1977; 1978a; 1979b; 1980a, b; 1981a, b, c, d; 1982a; 1983a; 1984a; 1986a, b; 1987f, g; 1992a ,b, c; 1993a, c; 1997; 1998a; 2000)

$\Delta$ 10-year flood-recurrence-interval elevation (FEMA 1976a, b, c; 1977; 1978a; 1979b; 1980a, b; 1981a, b, c, d; 1982a; 1983a; 1984a; 1986a, b; 1987f, g; 1992a ,b, c; 1993a, c; 1997; 1998a; 2000)

$\Delta$ June 26-29, 2006, peak water-surface elevation (US Geological Survey)

Figure 13C. Peak water-surface elevations at selected sites in the Susquehanna River basin, NY, during flood of June 26-29, 2006, and flood-recurrence-interval elevations from Federal Emergency Management Agency floodinsurance studies. (Site names and locations are shown in table 5.) 


\section{Susquehanna River basin flood elevations}
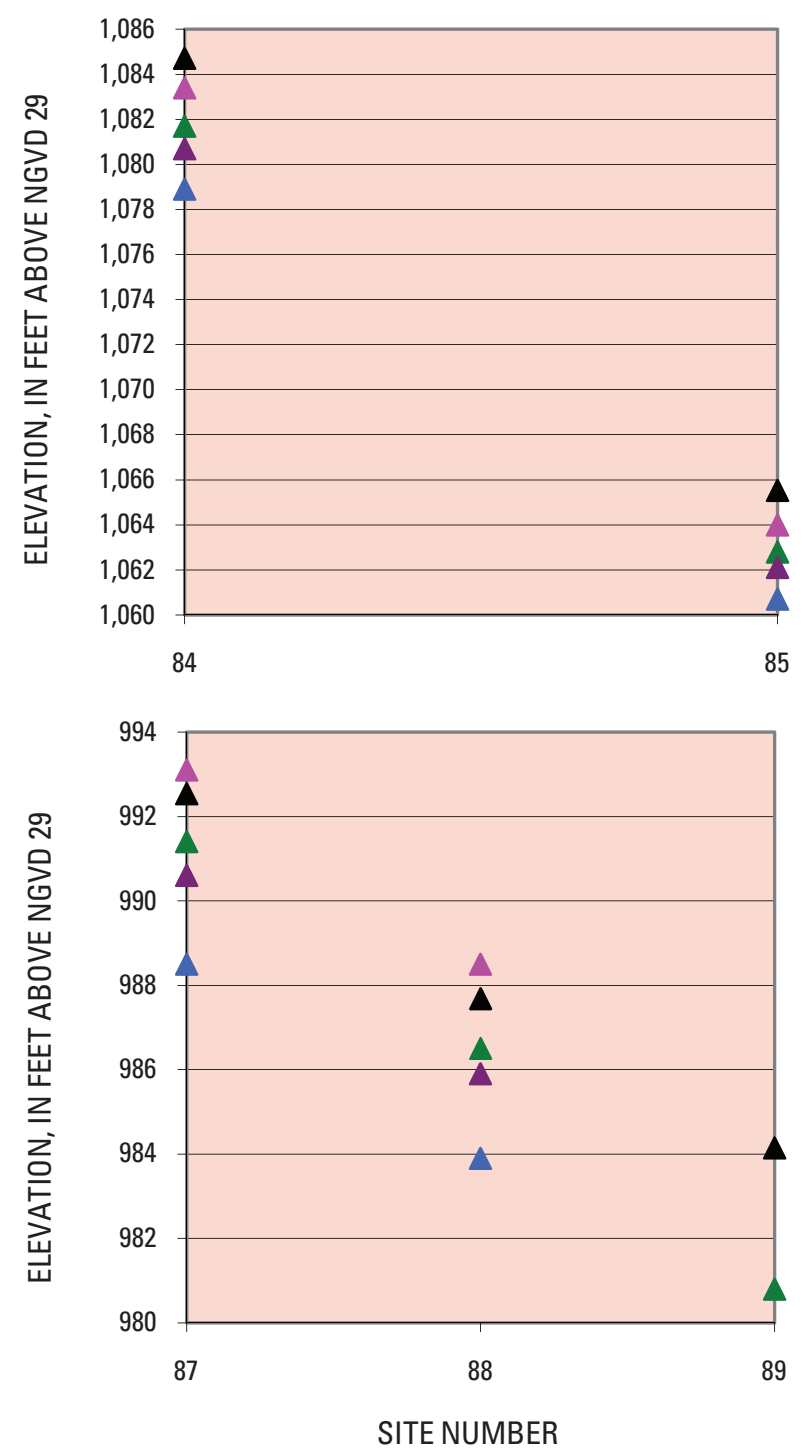

\section{Susquehanna River basin flood elevations}

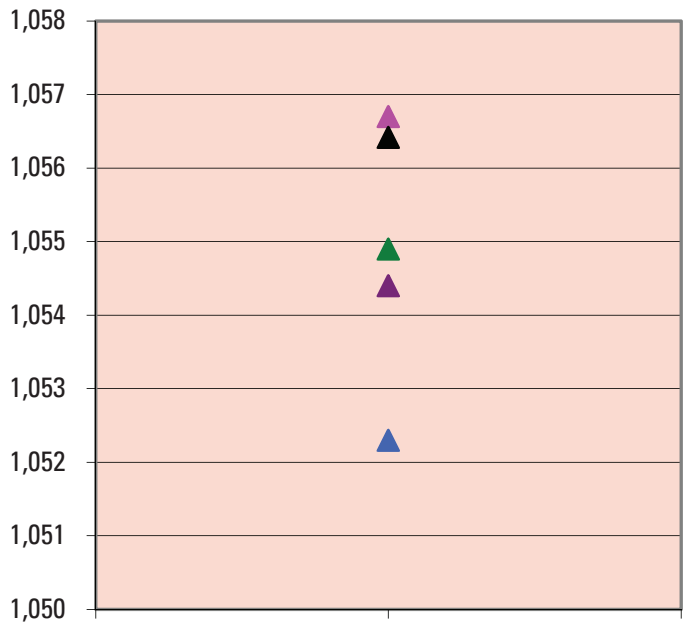

86

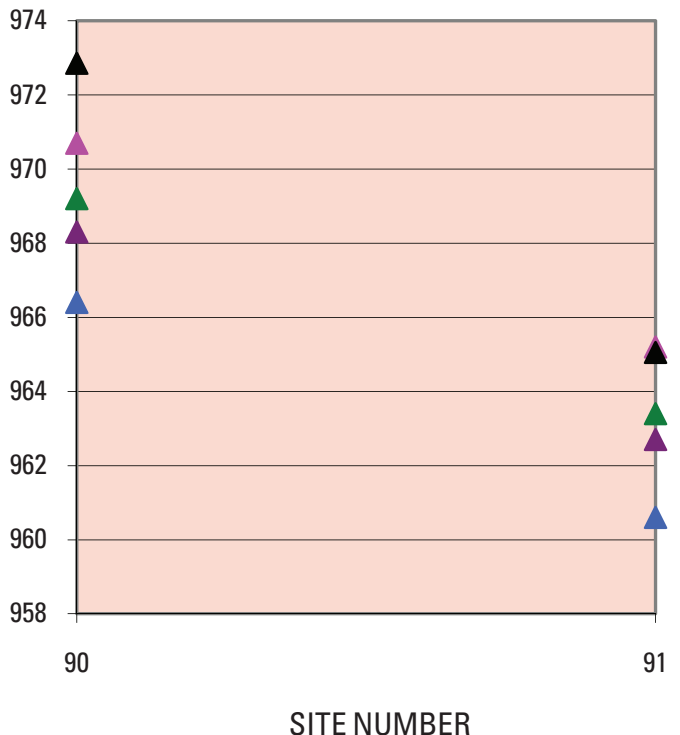

\section{EXPLANATION}

$\triangle$ 500-year flood-recurrence-interval elevation (FEMA 1976a, b, c; 1977; 1978a; 1979b; 1980a, b; 1981a, b, c, d; 1982a; 1983a; 1984a; 1986a, b; 1987f, g; 1992a ,b, c; 1993a, c; 1997; 1998a; 2000)

$\Delta$ 100-year flood-recurrence-interval elevation (FEMA 1976a, b, c; 1977; 1978a; 1979b; 1980a, b; 1981a, b, c, d; 1982a; 1983a; 1984a; 1986a, b; 1987f, g; 1992a ,b, c; 1993a, c; 1997; 1998a; 2000)

150-year flood-recurrence-interval elevation (FEMA 1976a, b, c; 1977; 1978a; 1979b; 1980a, b; 1981a, b, c, d; 1982a; 1983a; 1984a; 1986a, b; 1987f, g; 1992a , b, c; 1993a, c; 1997; 1998a; 2000)

\10-year flood-recurrence-interval elevation (FEMA 1976a, b, c; 1977; 1978a; 1979b; 1980a, b; 1981a, b, c, d; 1982a; 1983a; 1984a; 1986a, b; 1987f, g; 1992a ,b, c; 1993a, c; 1997; 1998a; 2000)

\ June 26-29, 2006, peak water-surface elevation (US Geological Survey)

Figure 13C. Peak water-surface elevations at selected sites in the Susquehanna River basin, NY, during flood of June 26-29, 2006, and flood-recurrence-interval elevations from Federal Emergency Management Agency floodinsurance studies. (Site names and locations are shown in table 5.) 


\section{Susquehanna River basin flood elevations}
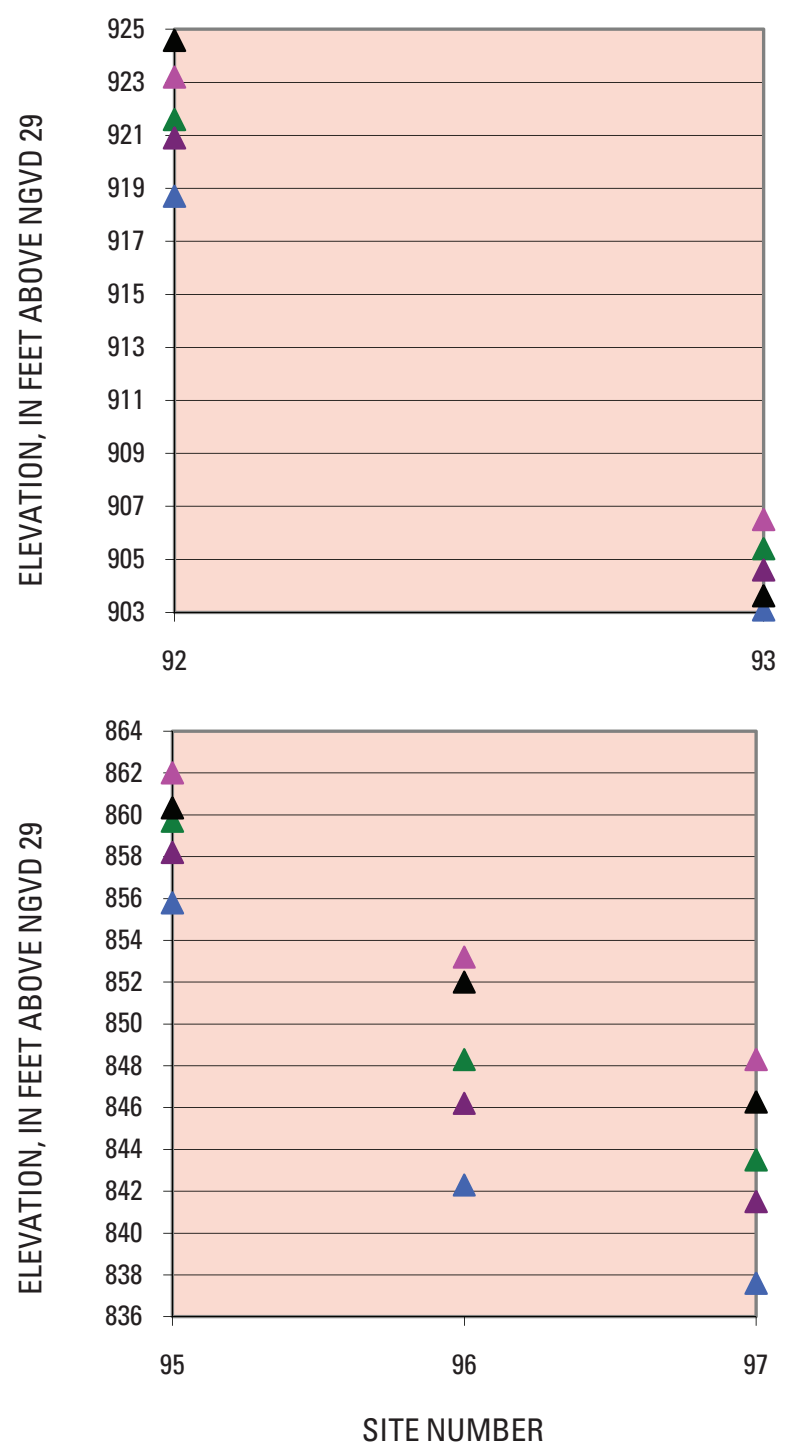

\section{Susquehanna River basin flood elevations}

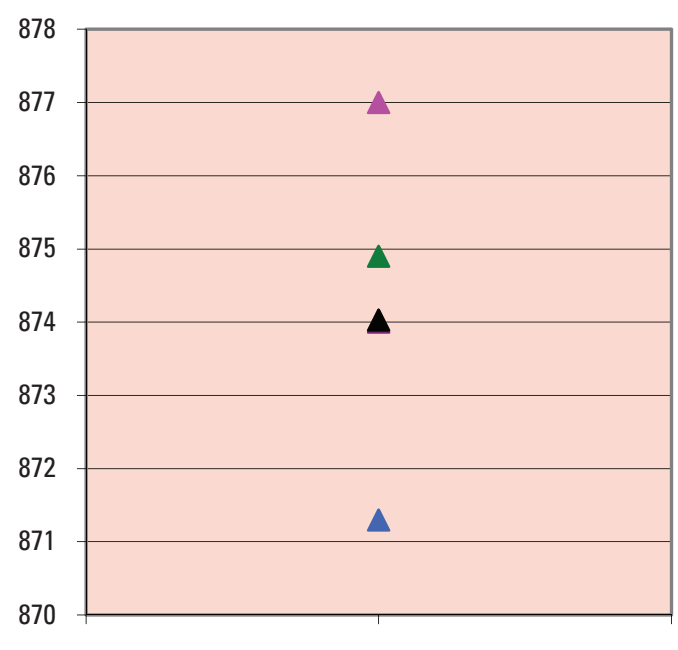

94

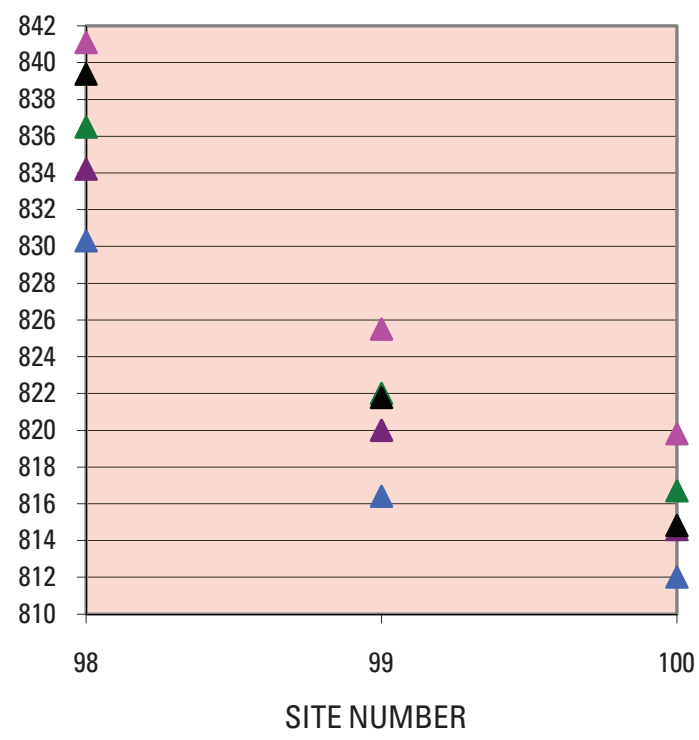

\section{EXPLANATION}

$\triangle 500$-year flood-recurrence-interval elevation (FEMA 1976a, b, c; 1977; 1978a; 1979b; 1980a, b; 1981a, b, c, d; 1982a; 1983a; 1984a; 1986a, b; 1987f, g; 1992a ,b, c; 1993a, c; 1997; 1998a; 2000)

$\triangle 100$-year flood-recurrence-interval elevation (FEMA 1976a, b, c; 1977; 1978a; 1979b; 1980a, b; 1981a, b, c, d; 1982a; 1983a; 1984a; 1986a, b; 1987f, g; 1992a ,b, c; 1993a, c; 1997; 1998a; 2000)

$\Delta$ 50-year flood-recurrence-interval elevation (FEMA 1976a, b, c; 1977; 1978a; 1979b; 1980a, b; 1981a, b, c, d; 1982a; 1983a; 1984a; 1986a, b; 1987f, g; 1992a ,b, c; 1993a, c; 1997; 1998a; 2000)

$\triangle 10$-year flood-recurrence-interval elevation (FEMA 1976a, b, c; 1977; 1978a; 1979b; 1980a, b; 1981a, b, c, d; 1982a; 1983a; 1984a; 1986a, b; 1987f, g; 1992a ,b, c; 1993a, c; 1997; 1998a; 2000)

$\Delta$ June 26-29, 2006, peak water-surface elevation (US Geological Survey)

Figure 13C. Peak water-surface elevations at selected sites in the Susquehanna River basin, NY, during flood of June 26-29, 2006, and flood-recurrence-interval elevations from Federal Emergency Management Agency floodinsurance studies. (Site names and locations are shown in table 5.) 


\section{Susquehanna River basin \\ flood elevations}

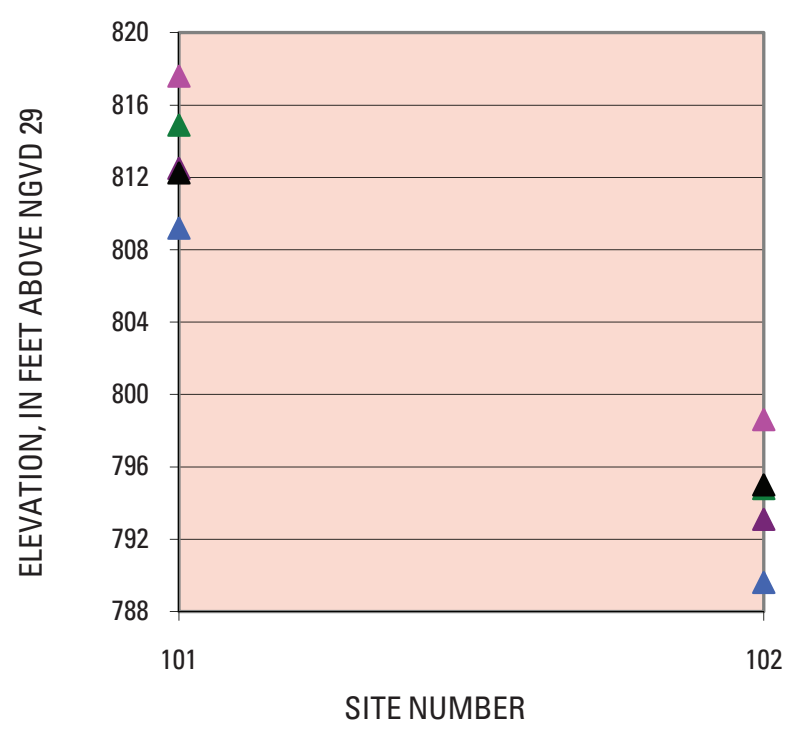

\section{Susquehanna River basin flood elevations}

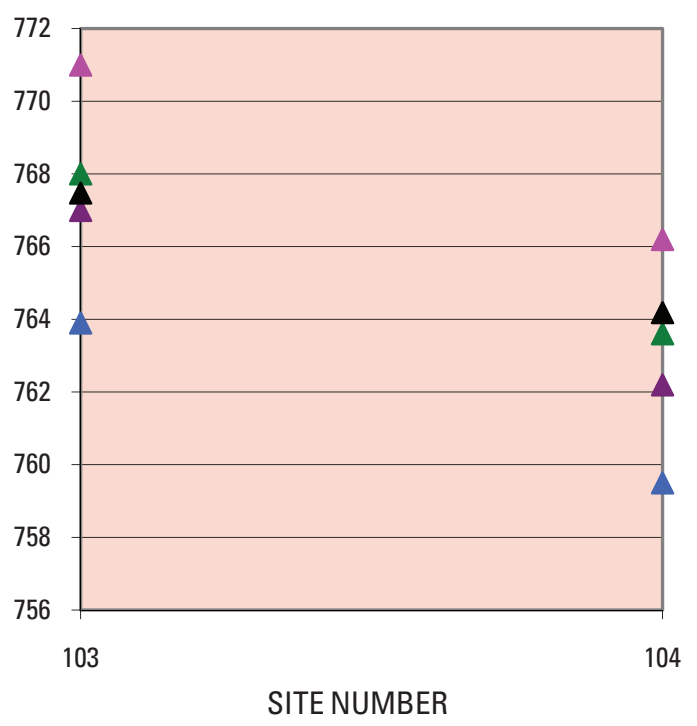

\section{EXPLANATION}

$\triangle$ 500-year flood-recurrence-interval elevation (FEMA 1976a, b, c; 1977; 1978a; 1979b; 1980a, b; 1981a, b, c, d; 1982a; 1983a; 1984a; 1986a, b; 1987f, g; 1992a ,b, c; 1993a, c; 1997; 1998a; 2000)

$\Delta$ 100-year flood-recurrence-interval elevation (FEMA 1976a, b, c; 1977; 1978a; 1979b; 1980a, b; 1981a, b, c, d; 1982a; 1983a; 1984a; 1986a, b; 1987f, g; 1992a ,b, c; 1993a, c; 1997; 1998a; 2000)

$\Delta$ 50-year flood-recurrence-interval elevation (FEMA 1976a, b, c; 1977; 1978a; 1979b; 1980a, b; 1981a, b, c, d; 1982a; 1983a; 1984a; 1986a, b; 1987f, g; 1992a ,b, c; 1993a, c; 1997; 1998a; 2000)

$\Delta$ 10-year flood-recurrence-interval elevation (FEMA 1976a, b, c; 1977; 1978a; 1979b; 1980a, b; 1981a, b, c, d; 1982a; 1983a; 1984a; 1986a, b; 1987f, g; 1992a ,b, c; 1993a, c; 1997; 1998a; 2000)

$\Delta$ June 26-29, 2006, peak water-surface elevation (US Geological Survey)

Figure 13C. Peak water-surface elevations at selected sites in the Susquehanna River basin, NY, during flood of June 26-29, 2006, and flood-recurrence-interval elevations from Federal Emergency Management Agency floodinsurance studies. (Site names and locations are shown in table 5.) 
between the 100- and 500-year flood-profile elevations. At Greene (sites 77 and 78), the peak water-surface elevations were near the 500-year flood-profile elevations, and at the Chenango River at Greene stream-gaging station (01507000), the recorded peak water-surface elevation was near the 500year flood profile. The peak discharge at the Chenango River at Greene stream-gaging station has a recurrence interval of greater than 100 years. At the USGS stream-gaging station Chenango River at Chenango Forks (01512500), $1.2 \mathrm{mi}$ downstream from the confluence with the Tioughnioga River, the recorded peak water-surface elevation was in the range of the 10-year flood profile and the peak discharge indicated about a 20-year recurrence interval, but farther downstream at Dickinson (site 79) and at Binghamton (site 80), the peak water-surface elevations were in the range of the 100-year and the 500-year flood-profile elevations, respectively. These higher peak water-surface elevations at sites 79 and 80 were primarily because of backwater from the Susquehanna River.

The Susquehanna River was studied from Cooperstown, NY, (site 81) downstream to Athens, PA (site 104). FEMA flood-insurance studies were available for most study sites along the study reach of the Susquehanna River. The 100 -year flood profile was the only profile available for the Cooperstown study site (site 81), and the peak watersurface elevation was higher than the 100-year flood-profile elevation. Peak water-surface elevations from Oneonta (site 84 ) to Otego (site 86) were generally equal to or higher than the 500-year flood-profile elevation. Along the Susquehanna River near the communities of Unadilla and Sidney (sites 87 and 88 ), the peak water-surface elevations were generally between the 100- and the 500-year flood-profile elevations. At the Susquehanna River at Unadilla stream-gaging station (01500500), the recorded peak water-surface elevation was at the 500-year flood-profile elevation, and the peak discharge indicated a recurrence interval greater than 100 years (table 3 ). The 100-year flood profile was the only profile available for the Bainbridge area. At Bainbridge (site 89), the peak water-surface elevation was $3.2 \mathrm{ft}$ higher than the 100-year flood-profile elevation. The Susquehanna River at Bainbridge stream-gaging station (01502632) recorded a peak watersurface elevation that was $2.9 \mathrm{ft}$ higher than the 100 -year flood-profile elevation and a peak discharge that indicated a recurrence interval of greater than 100 years. Downstream in the communities of Afton (site 90), Nineveh (site 91), and Windson (site 92), the peak water-surface elevations were equal to or higher than the 500-year flood-profile elevations. Peak water-surface elevations at Susquehanna Depot, PA, (site 93) and Great Bend, PA, (site 94) were generally in the range of the 50-year flood profile. The USGS streamgaging station Susquehanna River at Conklin (01503000) recorded a peak water-surface elevation that was greater than the 500-year flood profile at its location, and the peak discharge indicated a recurrence interval greater than 100 years. Peak water-surface elevations in the communities of
Conklin (site 95) downstream through the City of Binghamton (sites 96 and 97) to Johnson City (site 98) were determined to be between the range of the 100- and 500-year flood-profile elevations. At the Susquehanna River at Vestal stream-gaging station (01513500), the recorded peak water-surface elevation was between the 100- and 500-year flood profiles, and the peak discharge indicated a recurrence interval of greater than 100 years. Peak water-surface elevations in the area of Campville, NY, (site 99) downstream through sites 100 to 103 to Athens, PA, (site 104) in general were determined to be in the range of the 50- and 100-year flood-profile elevations. At the Susquehanna River at Waverly stream-gaging station (01515000), the recorded peak water-surface elevation was slightly higher than the 50-year flood profile, and the peak discharge indicated a recurrence interval of 40 years

\section{Flood Damage}

A state of emergency was declared by officials in several towns in the 12 counties that were declared Federal disaster areas after the severe flooding of June 26-29, 2006. Hundreds of residents that live near the East Canada Creek and the Mohawk River were asked to evacuate their homes because of the flooding. On June 28, 2006, the New York State Canal Corporation closed the Erie Canal system from Lock 2 west to Lock 22 and the entire Champlain Canal system because of high water. Among the damages caused by the flood in the Mohawk River basin are the collapse of a historic restaurant in Dolgeville into the East Canada Creek on June 28, damage to several of the New York State Canal Corporations locks along the Erie Canal, and millions of dollars in damage to the BeechNut Nutrition Corporation's facilities in Canajoharie and Fort Plain (Daily Gazette, 2008). Many of the communities that experienced major flooding in the recent September 2004 and April 2005 floods in the Delaware River basin were flooded again during June 2006. At least 1,000 residents were asked to evacuate the City of Port Jervis by June 28 . The community of Livingston Manor was flooded by tributaries to the East Branch of the Delaware River. Local officials indicated that the flood hit the community suddenly, and many residents had to be rescued from their homes by emergency personnel (Times Herald Record, 2006). The flood of June 2006 was blamed for four deaths across New York, one of which was that of a 15 year-old girl in Livingston Manor who was swept away from her front porch as she waited to be rescued and the front section of her home collapsed into the floodwaters of Cattail Brook, a tributary to the Willowemoc Creek (Times Herald Record, 2006) in the morning of June 28.

In the Susquehanna River basin three people died during the morning of June 28 as a result of the flooding. One man perished when his truck plunged into White Stone Brook, a tributary to the Unadilla River, when the culvert under 
Holmesville Hill Road in the Town of Norwich washed out. Two men lost their lives when their tractor trailers plunged into Carrs Creek, a tributary to the Susquehanna River, when the culvert under Interstate Route 88 in the Town of Sidney washed out (fig 14A). Along the banks of the Susquehanna River, several communities were inundated, and the City of Binghamton was not spared from the flooding (fig. 14B). Four to five thousand residents were evacuated, many roads were closed, including State Route 17 in both directions, and several thousand residents were left without power. Several days later on July 1, boil water advisories remained in effect for several towns including the towns of Union, Windsor, and Vestal, NY. More than 15,500 individuals had applied for assistance by September 1, 2006, and FEMA announced that families, individuals, and businesses who were adversely affected by the flooding in June 2006 had received more than \$112 million in assistance from FEMA, the Small Business Administration, and the State of New York (Federal Emergency Management Agency, 2006). On December 29, 2006, FEMA announced that the amount of disaster assistance approved for New York families, businesses, and public entities had been increased to more than \$227 million. Photographs of flood damage to selected areas in the Mohawk, Delaware, and Susquehanna River basins are shown in appendix 3 .

\section{Summary}

Extended heavy rains that spread south to north across southern New York produced widespread rainfall amounts of 5 to $6 \mathrm{in}$. and localized reports of greater than $13 \mathrm{in}$. in several areas in New York. Prior to June 2006, streamflow conditions in the Mohawk, Delaware, and Susquehanna River regions were generally in the normal to dry range. Rainfall from this storm produced new period-of-record peak water-surface elevations and discharges at several USGS stream-gaging stations, including those at Mohawk River at Little Falls, West Branch Delaware River at Hale Eddy, and Susquehanna River at Conklin, NY. These stations and several others also recorded peak discharges that exceeded the 100-year recurrence interval as a result of this storm. Prior to the June 2006 flood, the Hinckley Reservoir was at 93 percent of capacity, and the Cannonsville and Pepacton Reservoirs were both at 101 percent of capacity. East Sidney and Whitney Point Lake, flood-control reservoirs operated by the U.S. Army Corp of Engineers, were at 10 and 15 percent of capacity, respectively, prior to the storm. Although most of the reservoirs in the Mohawk, Delaware, and Susquehanna River basins did eventually spill, with the exceptions of Whitney Point Lake, Prompton Reservoir, and General Edgar Jadwin Reservoir, they all managed to attenuate the flood magnitude to downstream communities. Four lives were lost, thousands of people were asked to evacuate, hundreds of miles of roadway were closed, and many homes were damaged or lost as a result of this flood. The Department of Homeland Security, Federal Emergency Management Agency (Federal Emergency Management Agency, 2006) announced that a major disaster had been declared for New York to supplement state and local recovery efforts in the areas struck by severe storms and flooding that began on June 26, 2006. Twelve counties in New York were named in the disaster declaration, and by December 29, 2006, FEMA had announced that families, individuals, businesses, and public entities had received more than $\$ 227$ million in assistance from FEMA, the Small Business Administration, and the State of New York for damages not covered by insurance and for state and local agencies to repair flood damages and rebuild infrastructure damaged during the flood .

This report studied 104 sites in the combined Mohawk, Delaware, and Susquehanna River basins. Peak water-surface elevations were surveyed and compared to flood-profile elevations in the flood-insurance studies published by FEMA. Peak water-surface elevations at many of the study sites were determined to be greater than the 100-year flood-profile elevations, and some were determined to be greater than the 500-year flood-profile elevations. Along the Delaware River, the peak discharge during the June 2006 flood was greater than that from the August 1955 flood at the USGS streamgaging station at Delaware River above Lackawaxen River near Barryville, NY; and at the USGS stream-gaging stations on the Delaware River at Port Jervis, NY, and Montague, NJ, the peak discharges were the highest since 1955. The June 2006 flood produced greater peak discharges/ than the March 1977 flood along parts of the Mohawk River and greater than the July 1935 and March 1936 floods in parts of the upper Susquehanna River basin in New York.

\section{Acknowledgements}

Thanks are extended to the New York State Department of Transportation for cooperating with the USGS to compute updated flood frequencies for the stream-gaging stations, and to the National Weather Service and New York City Department of Environmental Protection for providing data included in this report. Thanks also are extended to the following USGS hydrologists and hydrologic technicians who collected the data for this report during and after the flood: L.T. Brooks, W.F. Coon, A.M. Gearwar, J.S. Grover, M.E. Hendricks, T.F. Hoffman, M.B. Jennings, R. Lumia, J.P. Marion, K. McGrath, S.K. McInnes, A.G. Morgan, K.D. Reisig, J.E. Smith, M.J. Welsh, H.J. Zajd, and B.J. Zatorsky. 

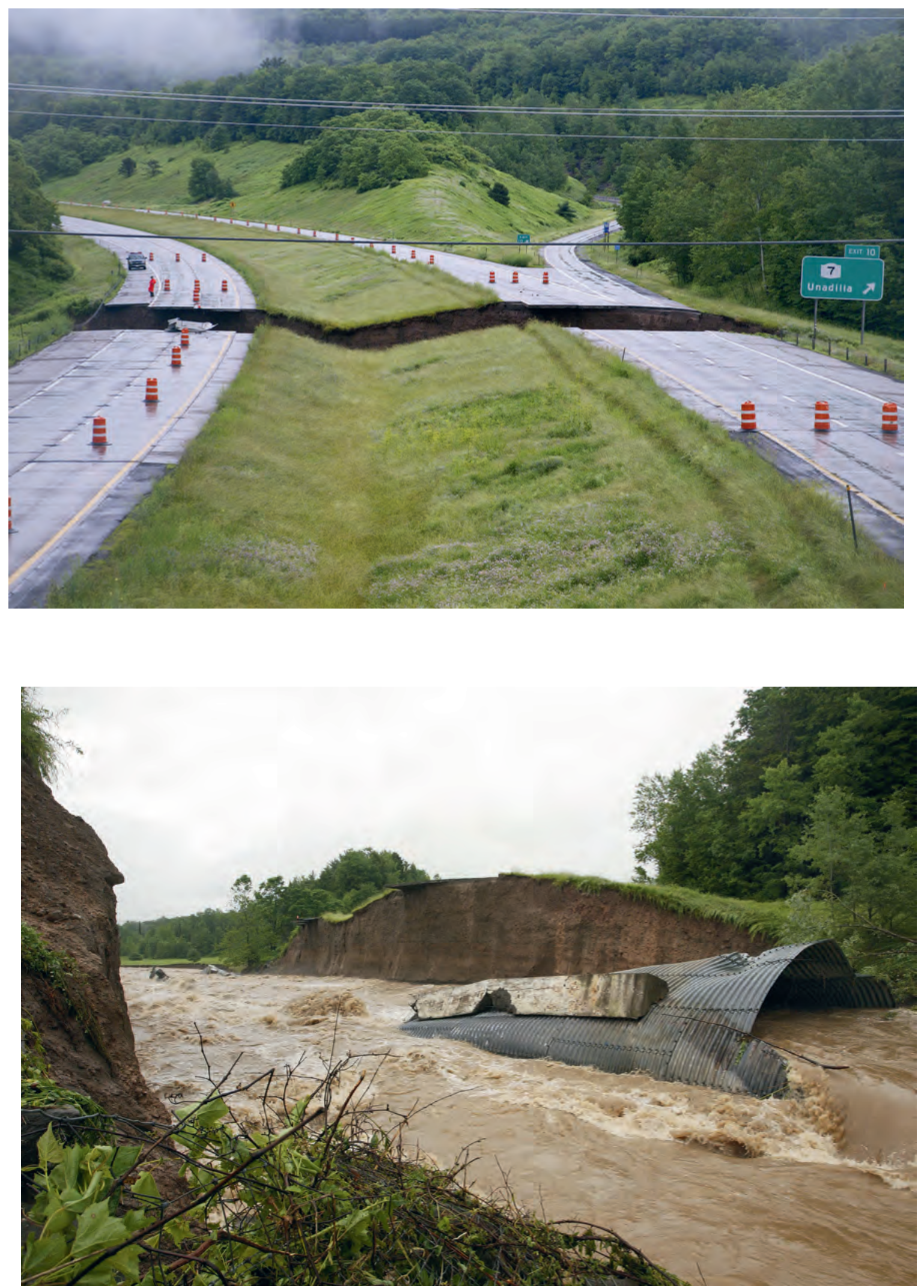

Figure 14A. Top-Collapse of Interstate Route 88 over Carrs Creek near Unadilla (Exit 10), NY, on June 28, 2006. Bottom-Carrs Creek and washed-out culvert at Interstate Route 88 near Unadilla (exit 10), NY, on June 28, 2006. Photos courtesy of The Daily Star, taken by staff photographer Julie Lewis. 

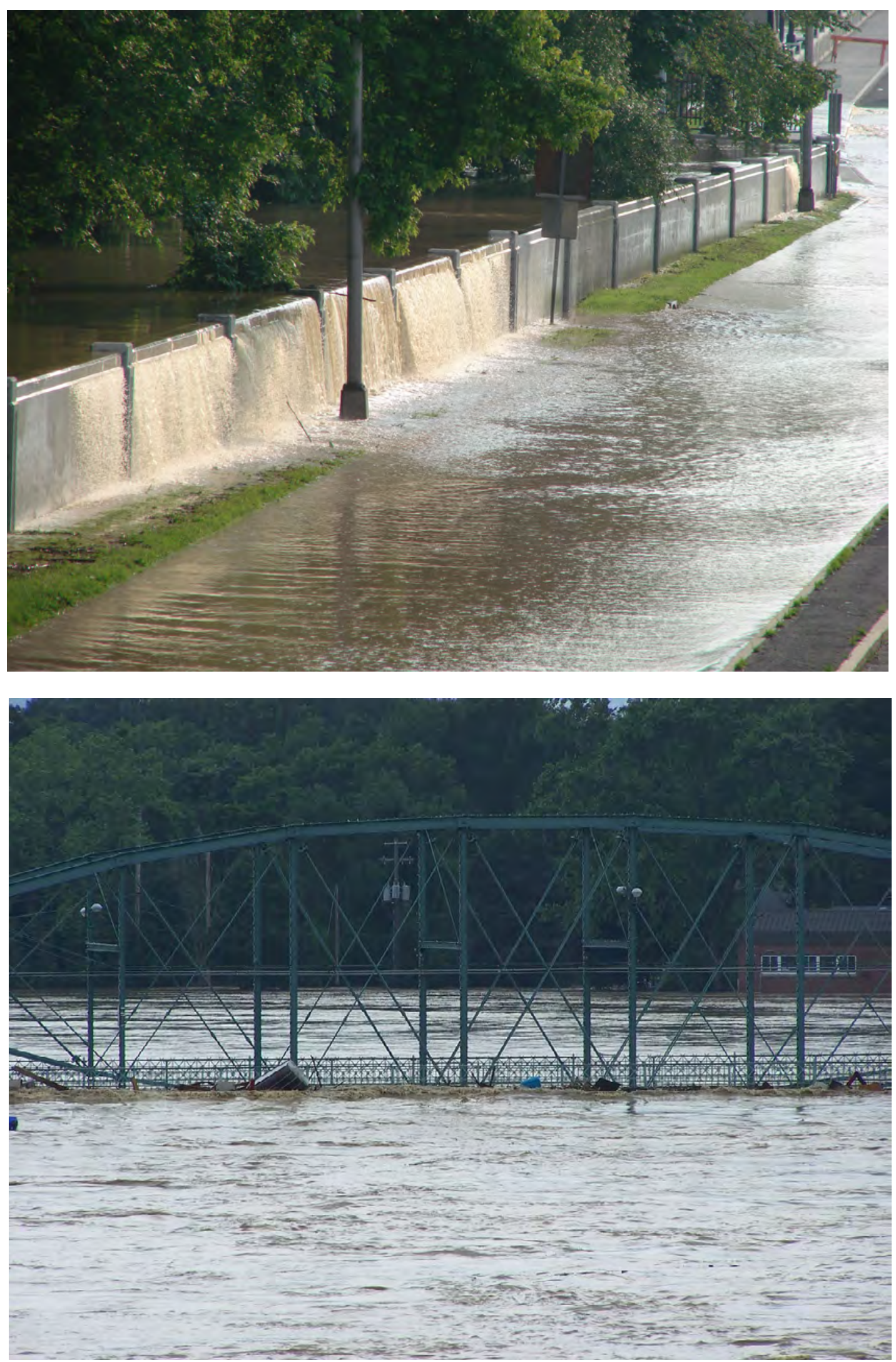

Figure 14B. Top-Susquehanna River floodwaters overtop floodwall along North Shore Drive, Binghamton, NY, on June 28, 2006. Photo courtesy of Alan A. Katz. Bottom-Susquehanna River floodwaters overflow Washington Street pedestrian bridge, Binghamton, NY, on June 28, 2006. Photo courtesy of James Willis. 


\section{Selected References}

Bailey, J.F., and others, 1975, Hurricane Agnes rainfall and flood, June--July 1972: U.S. Geological Survey Professional Paper 924, 403 p.

Benson, M.A., and Dalrymple, Tate, 1967, General field and office procedures for indirect discharge measurements: U.S. Geological Survey Techniques of Water-Resources Investigations, book 3, chap. A1, 30 p.

Binghamton, City of, New York, 2006, City of BinghamtonFlood Updates: June 2006 Flood, accessed June 4, 2008, at http:/www.cityofbinghamton.com/flood.asp

Bogart, D.B., 1960, Floods of August-October 1955 New England to North Carolina: U.S. Geological Survey WaterSupply Paper 1420, 854 p.

Brooks, L.T., 2005, Flood of September 18-19, 2004 in the Upper Delaware River Basin, New York: U.S. Geologcial Survey Open-File Report 2005-1166, 123 p.

Broome County, New York, 2006, News release archives June 2006: accessed June 4, 2008, at http://www. gobroomecounty.com/press/PressArchives2006.php

Daily Gazette, 2008, Town OKs Beech-Nut plan: Schenectady, N.Y., May 16, 2006, accessed June 4, 2008, at http://www.dailygazette.com/news/2008/may/16/0516 beech/.

Federal Emergency Management Agency, 1976a, Flood Insurance Study, Town of Dickinson, Broome County, New York: Federal Emergency Management Agency, Federal Insurance Administration, 1976, 14 p.

Federal Emergency Management Agency, 1976b, Flood Insurance Study, Town of Conklin, Broome County, New York: Federal Emergency Management Agency, Federal Insurance Administration, 1976, 17 p.

Federal Emergency Management Agency, 1976c, Flood Insurance Study, City of Binghamton, Broome County, New York: Federal Emergency Management Agency, Federal Insurance Administration, 1976, 18 p.

Federal Emergency Management Agency, 1977, Flood Insurance Study, Village of Johnson City, Broome County, New York: Federal Emergency Management Agency, Federal Insurance Administration, 1977, 14 p.

Federal Emergency Management Agency, 1978a, Flood Insurance Study, City of Oneonta, Otsego County, New York: Federal Emergency Management Agency, Federal Insurance Administration, 1978, 20 p.
Federal Emergency Management Agency, 1978b, Flood Insurance Study, Village of Deposit, Broome and Delaware Counties, New York: Federal Emergency Management Agency, Federal Insurance Administration, 1978, 17 p.

Federal Emergency Management Agency, 1979a, Flood Insurance Study, City of Cohoes, Albany County, New York: Federal Emergency Management Agency, Federal Insurance Administration, 1979, 25 p.

Federal Emergency Management Agency, 1979b, Flood Insurance Study, Township of Athens, Bradford County, Pennsylvania: Federal Emergency Management Agency, Federal Insurance Administration, 1979, 25 p.

Federal Emergency Management Agency, 1979c, Flood Insurance Study, Town of Sanford, Broome County, New York: Federal Emergency Management Agency, Federal Insurance Administration, 1979, 20 p.

Federal Emergency Management Agency, 1980a, Flood Insurance Study, Borough of Susquehanna Depot, Susquehanna County, Pennsylvania: Federal Emergency Management Agency, Federal Insurance Administration, 1980, 15 p.

Federal Emergency Management Agency, 1980b, Flood Insurance Study, Township of Great Bend, Susquehanna County, Pennsylvania: Federal Emergency Management Agency, Federal Insurance Administration, 1980, 18 p.

Federal Emergency Management Agency, 1981a, Flood Insurance Study, Town of Fenton, Broome County, New York: Federal Emergency Management Agency, Federal Insurance Administration, 1981, 20 p.

Federal Emergency Management Agency, 1981b, Flood Insurance Study, Town of Greene, Chenango County, New York: Federal Emergency Management Agency, Federal Insurance Administration, 1981, 20 p.

Federal Emergency Management Agency, 1981c, Flood Insurance Study, Village of Greene, Chenango County, New York: Federal Emergency Management Agency, Federal Insurance Administration, 1981, 20 p.

Federal Emergency Management Agency, 1981d, Flood Insurance Study, Town of Nichols, Tioga County, New York: Federal Emergency Management Agency, Federal Insurance Administration, 1981, 17 p.

Federal Emergency Management Agency, 1982a, Flood Insurance Study, Village of Owego, Tioga County, New York: Federal Emergency Management Agency, Federal Insurance Administration, 1982, 15 p.

Federal Emergency Management Agency, 1982b, Flood Insurance Study, Village of Fultonville, Montgomery County, New York: Federal Emergency Management Agency, Federal Insurance Administration, 1982, 15 p. 
Federal Emergency Management Agency, 1982c, Flood Insurance Study, Village of Canajoharie, Montgomery County, New York: Federal Emergency Management Agency, Federal Insurance Administration, 1982, 16 p.

Federal Emergency Management Agency, 1982d, Flood Insurance Study, Village of Fonda, Montgomery County, New York: Federal Emergency Management Agency, Federal Insurance Administration, 1982, 16 p.

Federal Emergency Management Agency, 1982e, Flood Insurance Study, Village of Dolgeville, Herkimer and Fulton Counties, New York: Federal Emergency Management Agency, Federal Insurance Administration, 1982, 18 p.

Federal Emergency Management Agency, 1982f, Flood Insurance Study, City of Little Falls, Herkimer County, New York: Federal Emergency Management Agency, Federal Insurance Administration, 1982, 17 p.

Federal Emergency Management Agency, 1983a, Flood Insurance Study, City of Cortland, Cortland County, New York: Federal Emergency Management Agency, Federal Insurance Administration, 1983, 15 p.

Federal Emergency Management Agency, 1983b, Flood Insurance Study, Town of Rotterdam, Schenectady County, New York: Federal Emergency Management Agency, Federal Insurance Administration, 1983, 19 p.

Federal Emergency Management Agency, 1984a, Flood Insurance Study, Town of Norwich, Chenango County, New York: Federal Emergency Management Agency, Federal Insurance Administration, 1984, 18 p.

Federal Emergency Management Agency, 1984b, Flood Insurance Study, City of Amsterdam, Montgomery County, New York: Federal Emergency Management Agency, Federal Insurance Administration, 1984, 18 p.

Federal Emergency Management Agency, 1985, Flood Insurance Study, Village of Delhi, Delaware County, New York: Federal Emergency Management Agency, Federal Insurance Administration, 1985, 13 p.

Federal Emergency Management Agency, 1986a, Flood Insurance Study, Town of Oneonta, Otsego County, New York: Federal Emergency Management Agency, Federal Insurance Administration, 1986, $21 \mathrm{p}$.

Federal Emergency Management Agency, 1986b, Flood Insurance Study, Village of Otego, Otsego County, New York: Federal Emergency Management Agency, Federal Insurance Administration, 1986, 17 p.

Federal Emergency Management Agency, 1987a, Flood Insurance Study, Town of Delaware, Sullivan County, New York: Federal Emergency Management Agency, Federal Insurance Administration, 1987, 16 p.
Federal Emergency Management Agency, 1987b, Flood Insurance Study, Town of Colchester, Delaware County, New York: Federal Emergency Management Agency, Federal Insurance Administration, 1987, 16 p.

Federal Emergency Management Agency, 1987c, Flood Insurance Study, Town of Highland, Sullivan County, New York: Federal Emergency Management Agency, Federal Insurance Administration, 1987, 14 p.

Federal Emergency Management Agency, 1987d, Flood Insurance Study, Town of Glenville, Schenectady County, New York: Federal Emergency Management Agency, Federal Insurance Administration, 1987, 18 p.

Federal Emergency Management Agency, 1987e, Flood Insurance Study, Town of Cochecton, Sullivan County, New York: Federal Emergency Management Agency, Federal Insurance Administration, 1987, 14 p.

Federal Emergency Management Agency, 1987f, Flood Insurance Study, Town of Unadilla, Otsego County, New York: Federal Emergency Management Agency, Federal Insurance Administration, 1987, 15 p.

Federal Emergency Management Agency, 1987g, Flood Insurance Study, Village of Unadilla, Otsego County, New York: Federal Emergency Management Agency, Federal Insurance Administration, 1987, 13 p.

Federal Emergency Management Agency, 1988, Flood Insurance Study, Town of Walton, Delaware County, New York: Federal Emergency Management Agency, Federal Insurance Administration, 1988, 14 p.

Federal Emergency Management Agency, 1990a, Flood Insurance Study, Town of Hancock, Delaware County, New York: Federal Emergency Management Agency, Federal Insurance Administration, 1990, 22 p.

Federal Emergency Management Agency, 1990b, Flood Insurance Study, Village of Hancock, Delaware County, New York: Federal Emergency Management Agency, Federal Insurance Administration, 1990, 13 p.

Federal Emergency Management Agency, 1991a, Flood Insurance Rate Map, Village of Newport, Herkimer County, New York: Federal Emergency Management Agency, Federal Insurance Administration, 1991, 1 p.

Federal Emergency Management Agency, 1991b, Flood Insurance Study, Village of Walton, Delaware County, New York: Federal Emergency Management Agency, Federal Insurance Administration, 1991, 14 p.

Federal Emergency Management Agency, 1992a, Flood Insurance Study, Town of Barker, Broome County, New York: Federal Emergency Management Agency, Federal Insurance Administration, 1992, 16 p. 
Federal Emergency Management Agency, 1992b, Flood Insurance Study, Village of Windsor, Broome County, New York: Federal Emergency Management Agency, Federal Insurance Administration, 1992, $14 \mathrm{p}$.

Federal Emergency Management Agency, 1992c, Flood Insurance Study, Village of Afton, Chenango County, New York: Federal Emergency Management Agency, Federal Insurance Administration, 1992, $15 \mathrm{p}$.

Federal Emergency Management Agency, 1993a, Flood Insurance Study, Town of Colesville, Broome County, New York: Federal Emergency Management Agency, Federal Insurance Administration, 1993, $15 \mathrm{p}$.

Federal Emergency Management Agency, 1993b, Flood Insurance Study, Town of Rockland, Sullivan County, New York: Federal Emergency Management Agency, Federal Insurance Administration, 1993, $18 \mathrm{p}$.

Federal Emergency Management Agency, 1993c, Flood Insurance Study, Village of Bainbridge, Chenango County, New York: Federal Emergency Management Agency, Federal Insurance Administration, 1993, 12 p.

Federal Emergency Management Agency, 1997, Flood Insurance Study, Town of Owego, Tioga County, New York: Federal Emergency Management Agency, Federal Insurance Administration, 1997, $22 \mathrm{p}$.

Federal Emergency Management Agency, 1998a, Flood Insurance Study, Town of Vestal, Broome County, New York: Federal Emergency Management Agency, Federal Insurance Administration, 1998, $19 \mathrm{p}$.

Federal Emergency Management Agency, 1998b, Flood Insurance Study, City of Rome, Oneida County, New York: Federal Emergency Management Agency, Federal Insurance Administration, 1998, $19 \mathrm{p}$.

Federal Emergency Management Agency, 1999a, Flood Insurance Study, Town of Russia, Herkimer County, New York: Federal Emergency Management Agency, Federal Insurance Administration, 1999, $13 \mathrm{p}$.

Federal Emergency Management Agency, 1999b, Flood Insurance Study, Village of Poland, Herkimer County, New York: Federal Emergency Management Agency, Federal Insurance Administration, 1999, $11 \mathrm{p}$.

Federal Emergency Management Agency, 1999c, Flood Insurance Study, Town of Deerpark, Orange County, New York: Federal Emergency Management Agency, Federal Insurance Administration, 1999, $20 \mathrm{p}$.

Federal Emergency Management Agency, 2000, Flood Insurance Rate Map, Village of Cooperstown, Otsego County, New York: Federal Emergency Management Agency, Federal Insurance Administration, 2000, 1 p.
Federal Emergency Management Agency, 2001a, Flood Insurance Study, Village of Frankfort, Herkimer County, New York: Federal Emergency Management Agency, Federal Insurance Administration, 2001, 14 p.

Federal Emergency Management Agency, 2001b, Flood Insurance Study, Town of Lumberland, Sullivan County, New York: Federal Emergency Management Agency, Federal Insurance Administration, 2001, 16 p.

Federal Emergency Management Agency, 2002a, Flood Insurance Study, City of Port Jervis, Orange County, New York: Federal Emergency Management Agency, Federal Insurance Administration, 2002, 19 p.

Federal Emergency Management Agency, 2002b, Flood Insurance Study, Village of Fort Plain, Montgomery County, New York: Federal Emergency Management Agency, Federal Insurance Administration, 2002, 16 p.

Federal Emergency Management Agency, 2002c, Flood Insurance Study, Village of Herkimer, Herkimer County, New York: Federal Emergency Management Agency, Federal Insurance Administration, 2002, 20 p.

Federal Emergency Management Agency, 2002d, Flood Insurance Study, Town of Tusten, Sullivan County, New York: Federal Emergency Management Agency, Federal Insurance Administration, 2002, $16 \mathrm{p}$.

Federal Emergency Management Agency, 2006, New York Severe Storms and Flooding - Declared July 1, 2006: Federal Emergency Management Agency, Federal Insurance Administration, accessed January 19, 2007, at http://www. fema.gov/news/eventnews.fema?id $=6485$

Grover, N.C., 1937, The floods of March 1936, Part 2 Hudson River to Susquehanna River region: U.S. Geological Survey Water-Supply Paper 799, 380 p.

Helsel, D.R. and Hirsch, R.M. 1992, Statistical methods in water resources: The Netherlands, Elsevier Science Publishers, in Environmental Science 49, 522 p.

Hollister, Johnson, 1936, The New York State flood of July 1935: U.S. Geological Survey Water-Supply Paper 773E, p. 233-268.

Interagency Advisory Committee on Water Data, 1982, Guidelines for determining flood flow frequency, Bulletin 17B of the Hydrology Subcommittee: Reston, Va., U.S. Geological Survey, Office of Water Data Coordination, $183 \mathrm{p}$.

Lumia, Richard, 1998, Flood of January 19-20, 1996, in New York State: U.S. Geological Survey Water-Resources Investigations Report 97-4252, 61 p. 
Lumia, Richard, 2006, Magnitude and frequency of floods n New York: U.S. Geological Survey Scientific Investigations Report 2006-5112, 152 p.

National Oceanic and Atmospheric Administration, 2002, National Climatic Data Center Climate Watch June 2002: Asheville, N.C., accessed February 5, 2007, at http://lwf.ncdc.noaa.gov/oa/climate/extremes/2002/june/ extremes0602.html

National Oceanic and Atmospheric Administration, 2006a, Climatological Data, New York, June 2006: Asheville, N.C., National Climatic Data Center, v. 118, no. 06, 33 p.

National Oceanic and Atmospheric Administration, 2006b, Hourly Precipitation Data, New York, June 2006:

Asheville, N.C., National Climatic Data Center, v. 56, no. $06,21 \mathrm{p}$

National Oceanic and Atmospheric Administration, 2006c, Flood of June 2006: Binghamton, N.Y., National Weather Service, accessed January 19, 2007, at http://www.erh.noaa. gov/bgm/WeatherEvents/Flood/june2006/

National Oceanic and Atmospheric Administration, 2006d, Precipitation analysis May 2006: Monthly percent of normal precipitation, NY, National Weather Service, accessed January 19, 2007, at http://www.srh.noaa.gov/ rfcshare/precip_analysis_new.php

National Oceanic and Atmospheric Administration, 2006e, North American Vertical Datum Conversion Utility: Silver Spring, MD, National Geodetic Survey, accessed October through December 2007 at http://www.ngs.noaa.gov/ TOOLS/Vertcon/vertcon.html

New York State Department of Transportation, 2006, NYSDOT Announces progress on flood clean-up, most State roads open for travel: Albany, N.Y., accessed January 19, 2007, at https://www.nysdot.gov/portal/page/portal/ news/press-releases/2006/2006101

Pennsylvania Power and Light (PPL) Generation, LLC, and Kleinschmidt, 2002, Application for License for Major Project - existing dam, Lake Wallenpaupack, v.1, license application: Prepared for PPL Holtwood, LLC, presented before the Federal Energy Regulatory Commission, FREC Project 487, variously paged.
Randall A.D., 1996, Mean annual runoff, precipitation and evapotranspiration in the glaciated northern United States, 1951-80: U.S. Geological Survey Open-File Report 96-395, 2 pls.

Roland M.A., and Stuckey, M.H., 2007, Analysis of floodmagnitude and flood-frequency data for streamflow-gaging stations in the Delaware and North Branch Susquehanna River basins in Pennsylvania: U.S. Geological Survey Open-File Report 2007-1235, 21 p.

Schopp, R.D., and Firda, G.D., 2008, Flood magnitude and frequency of the Delaware River in New Jersey, New York, and Pennsylvania: U.S. Geological Survey Open-File Report 2008-1203, 7p.

Times Herald-Record, 2006, Special Feature-June 2006 Flooding: Middletown, N.Y., accessed Feb. 5, 2007, at http://archive.recordonline.com/flood06/flood2006.html/

U.S. Geological Survey, 1960, Compilation of records of surface waters of the United States through September 1950, Part 1-B North Atlantic Slope Basins, New York to York River: U.S. Geological Survey Water-Supply Paper 1302, $679 \mathrm{p}$.

U.S. Geological Survey, 1964, Compilation of records of surface waters of the United States, October 1950 to September 1960, Part 1-B North Atlantic Slope Basins, New York to York River: U.S. Geological Survey WaterSupply Paper 1722, 578 p.

U.S. Weather Bureau, 1961, Rainfall frequency atlas of the United States: Washington, D.C., Technical Paper no. 40, $115 \mathrm{p}$.

U.S. Weather Bureau, 1964, Two- to ten day precipitation for return periods of 2 to 100 years in the contiguous United States: Washington, D.C., Technical Paper no. 49, 29 p.

WKTV News Channel 2 Utica, 2006, Dolgeville

Restaurant collapses into East Canada Creek, accessed February 5, 2007, at http://www.wktv.com/news/2006flood/ 
This page has been left blank intentionally. 
This page has been left blank intentionally. 
This page has been left blank intentionally. 
Prepared by the Pembroke Publishing Service Center

For additional information write to: New York Water Science Center

U.S. Geological Survey

425 Jordan Road

Troy, NY 12180

Information requests:

(518) 285-5602

or visit our Web site at: http://ny.water.usgs.gov 
